ERDÉLYI TUDOMÁNYOS FÜZETEK

274

\author{
BOGDÁNDI ZSOLT
}

\title{
A KOLOZSMONOSTORI KONVENT A FEJEDELEMSÉG KORÁBAN
}

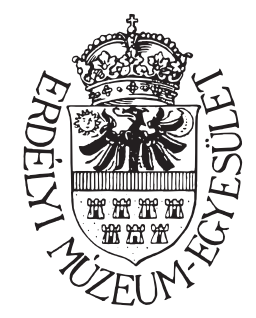

Kolozsvár, 2012 
A kötet megjelenését a Wekerle Sándor Alapkezelő támogatta.

(C) Bogdándi Zsolt

(C) Erdélyi Múzeum-Egyesület, 2012

\section{Felelős kiadó}

BIRÓ ANNAMÁRIA

Lektorálta

KOVÁCS ANDRÁS

OBORNI TERÉZ

Korrektúra

MEZÓ PIROSKA

ANDRÁS ZSELYKE

Müszaki szerkesztés, tördelés

BODÓ ZALÁN

Nyomdai munkálatok

GLORIA, Kolozsvár

Felelös vezető

NAGY PÉTER

Descrierea CIP a Bibliotecii Naționale a României

BOGDÁNDI, ZSOLT

A kolozsmonostori konvent a fejedelemség korában / Bogdándi

Zsolt. - Cluj Napoca : Societatea Muzeului Ardelean, 2012

Bibliogr.

ISBN 978-606-8178-46-2

930.25(498 Cluj-Mănăştur):94(498.4) 


\section{TARTALOM}

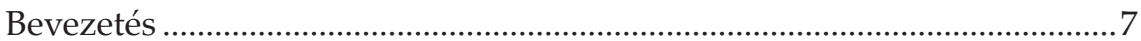

I. A kolozsmonostori konvent a szekularizáció előtt ......................................13

I. 1. A hiteleshelyek kialakulása ............................................................13

I. 2. A kolozsmonostori konvent hiteleshelyi tevékenysége

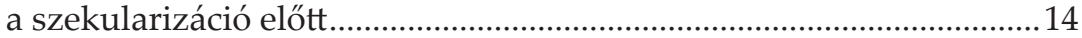

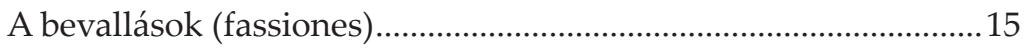

A külső hiteleshelyi tevékenység - jelentések (relationes) .............16

II. Az erdélyi hiteleshelyek a szekularizáció után ...........................................19

II. 1. A gyulafehérvári hiteleshely a szekularizáció után ......................20

A gyulafehérvári levélkeresők müködésének első korszaka (1557-1575) ................................................................................... 20

A gyulafehérvári hiteleshely első levélkeresői.................................21

A gyulafehérvári levélkeresők oklevelei a hiteleshely

újjászervezéséig (1575)......................................................................24

II. 2. A váradi hiteleshelyek a szekularizációt követően..........................25

A váradi requisitorok által kiadott oklevelek …………………….....26

III. A kolozsmonostori hiteleshely a requisitori intézmény megszervezéséig (1557-1575) .......................................................................2 29

IV. A hiteleshelyek szerepét átvevő intézmények a hiteleshelyi

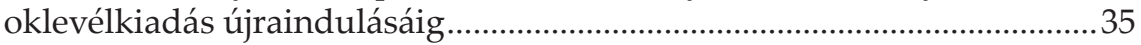

IV. 1. A királyi és vajdai/fejedelmi emberek hiteleshelyi jellegú tevékenysége Erdélyben..............................................................................36

IV. 2. A vármegyék hiteleshelyi jellegű tevékenysége.............................39

IV. 3. A fogott bírák (közbírák) oklevéladó tevékenysége ...................... 40

IV. 4. A fejedelmi kancellária hiteleshelyi jellegü tevékenysége...........41 V. A kolozsmonostori és gyulafehérvári hiteleshelyek újjászervezése. Az 1575. évi instrukció 
VI. A kolozsmonostori konvent fejedelemség kori levélkeresői ................51

VI. 1. A konvent szervezete....................................................................5 52

VI. 2. A levélkeresők kinevezése ..........................................................5 53

VI. 3. Jövedelmek..........................................................................54

VI. 4. Származás, háttér, korábbi pályafutás .......................................60

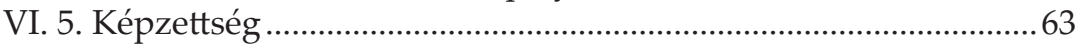

VI. 6. Felekezeti megoszlás .................................................................6 63

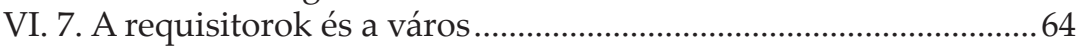

VI. 8. A requisitorok és a vármegye .....................................................66

VI. 9. A kolozsmonostori konvent fejedelemség kori levélkeresőinek jegyzéke ........................................................................................... 70

VII. A kolozsmonostori konvent oklevéladó tevékenysége

a fejedelemség korában ............................................................................99

VII. 1. A konvent előtt tett bevallások.................................................. 104

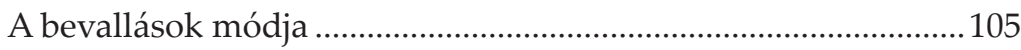

A bevallások tartalmi csoportosítása ............................................ 115

A kolozsmonostori konvent vonzáskörzete és forgalma a fejedelemség korában ............................................................... 132

A konvent forgalma....................................................................... 136

VII. 2. A konvent külső hiteleshelyi tevékenysége a fejedelemség

korában. A jelentések ......................................................................... 137

A magánügyfelek érdekében folytatott külső hiteleshelyi tevékenység .................................................................................. 139

A konvent területi hatásköre a jelentések alapján ....................... 146

A requisitorok a fejedelem szolgálatában ................................... 146

VII. 3. A konvent kiadványai ............................................................... 151

VII. 4. A konvent fejedelemség kori pecsétje ..................................... 154

VIII. A konvent levéltára és protocollumai a fejedelemség korában ........157

VIII. 1. A levéltárrendezések ................................................................ 162

VIII. 2. A fejedelemség kori protocollumok........................................ 164

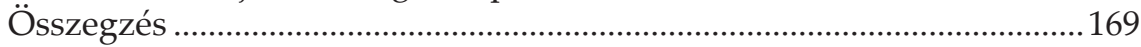

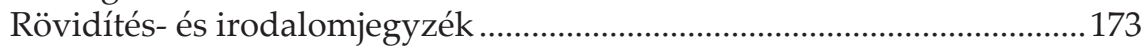

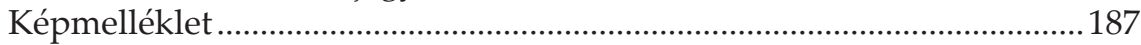

Személy- és helynévmutató.................................................................... 199

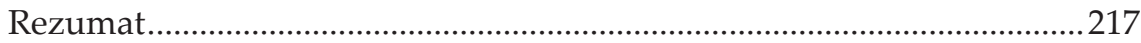

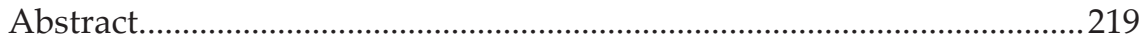




\section{BEVEZETÉS}

„Most, amikor fejlődése során történet-szemléletünk elérkezett arra a fokra, hogy a történetírástól ma már az események, jelenségek és a fejlődés értékelésén túl a személytelenül alakító tényezőnek, a történeti élet szerkezetének az ábrázolását is megkívánja, az erdélyi kutatónak szomorúan kell bevallania, hogy e kívánalom teljesítésében egyelőre alig leküzdhető akadályok gátolják". ${ }^{1}$ Habár Jakó Zsigmond idézett megállapítása óta több mint egy fél évszázad telt el, a helyzet azóta lényegében nem sokat változott. Egy-két kivétellel ma is kevés kutatót vonzanak a látványos és "eladható" eredményekkel kevésbé kecsegtetô, viszont aprólékos levéltári munkával járó hatóság-, hivatal-, közigazgatás- vagy jogtörténeti vizsgálatok.

Bizonyára ezek a körülmények okozták, hogy a jellemzően magyar intézménynek számító hiteleshelyek történetének kutatása viszonylag későn indult meg, a téma iránti tudományos érdeklődés inkább csak az utóbbi évtizedekben élénkült fel..$^{2}$ Ezek a közlemények azonban többnyire a középkori vagy inkább kora-középkori oklevéladó tevékenységet tárgyalják, annak ellenére, hogy éppen a neves középkorkutató Borsa Iván figyelmeztetett arra, hogy „nem szabad megfeledkezni arról sem, hogy Mohács után még három és egynegyed századon át működtek a hiteleshelyek". ${ }^{3} \mathrm{~A}$

\footnotetext{
${ }^{1}$ Jakó: Dézsma 3.

${ }^{2}$ A téma irodalmát kimerítően számba vette szócikkében Solymosi László, lásd Korai magyar történeti lexikon (9-14. század). Főszerk. Kristó Gyula. Szerk. Engel Pál és Makk Ferenc. Bp., 1994. 263-264.; Vö. Kőfalvi Tamás: A hiteleshelyi oklevelek egyháztörténeti tanulságai. In: Egyháztörténeti Szemle 1(2000). 1. sz. 61-64.; Bilkei: A zalavári és kapornaki konventek 90-93.

${ }^{3}$ Borsa Iván: A hiteleshelyekról. In: „Magyaroknak eleiről”. Ünnepi tanulmányok a hatvan esztendős Makk Ferenc tiszteletére. Szerk. Piti Ferenc. Szeged, 2000. 106.; Sill Ferenc 1976-ban közölt egy értekezést, melyben a vasvári káptalan újkori hiteleshelyi működését is taglalta, lásd $A$ vasvár-szombathelyi káptalan hiteleshelyi tevékenysége. In: Levéltári Évkönyv 1. Vas megye múltjából. Szombathely, 1976. 20-60. Az utóbbi években Bilkei Irén foglalkozott két magyar-
} 
kérdés kiemelkedő kutatója, Papp László pedig nem juthatott el a leleszi levéltárba, enélkül pedig átfogó hiteleshelyi levéltártörténetet írni, Borsa megfogalmazása szerint „nem lehet és nem is szabad."

A kialakuló Erdélyi Fejedelemség területén három, már évszázadok óta hiteleshelyi tevékenységet folytató egyházi intézmény működött: a gyulafehérvári székhelyű erdélyi káptalan, a kolozsmonostori konvent és a váradi káptalan. Mindhármuk középkori oklevéladó tevékenysége részben már feldolgozott, de egyikük esetében sem terjedt ki a kutatás a fejedelemség kori működésre. ${ }^{4}$ Egyedül a váradi káptalan esetében hivatkozhatunk a források hiányára, a vár 1660. évi elfoglalása után a káptalani levéltár elpusztult, de a kiadott oklevelek alapján itt is elképzelhető lenne egy kísérlet a hiteleshelyi tevékenység feldolgozására (van már erre is példa), a másik két hiteleshely levéltára azonban, a Magyar Országos Levéltár őrizetében, csonkán ugyan, de létezik és kutatható. ${ }^{5}$ Ezen intézmények újkori történetének feldolgozása, az általuk termelt protocollum-anyag jelentős részének közzététele megoldható, ugyanakkor sürgető feladat, hiszen e munkák által az erdélyi jog- és intézménytörténetre vonatkozó ismereteink nagymértékben bővülnének, és egyúttal megteremtődne az a forrásbázis, amely nélkül a történetírás továbblépni egyetlen területen sem képes.

Az erdélyi hiteleshelyek fejedelemség kori történetének kutatója rövid időn belül megállapíthatja, hogy az egyik jelentős és talán legjellegzetesebb, a magyar történelmet hosszú időn keresztül végigkísérő intézmény szakirodalma egy összefoglalás sommás fejezetéből és néhány résztanulmányból, illetve forrásközlésből áll. Úttörő jellege miatt először a forrásgyűjtő Kemény József Notitiáját említjük meg, amely annak ellenére, hogy a gyulafehérvári káptalan történetéről közölt adatokat, a kolozsmonostori konventre vonatkozóan is hasznosítható, minthogy e két hiteleshely története a szekularizációt követően összefonódott. ${ }^{6}$ Beke Antalnak az erdélyi káptalan és a kolozsmonostori konvent Erdélyben maradt okleveleiről készült XIX. század végi regesztái számos adalékot tartalmaznak az intézmények kora újkori tevékenységéről.7 Papp László 1936-ban megjelent doktori disszertációjának Erdély vonatkozásában nagy hiányossága, hogy

országi hiteleshely Mohács utáni tevékenységével, lásd A zalavári és a kapornaki konventek 87-130. A veszprémi káptalan oklevéladó müködését a nemrég előkerült jegyzőkönyv alapján Jakab Réka mutatta be. Lásd A veszprémi káptalan újkori hiteleshelyi tevékenysége az elsó felvallási jegyzókönyv alapján (1635-1653). In: Levéltári Szemle 2008/3. 82-90.

${ }^{4}$ Vekov: Alba Iulia; Sipos: Kolozsmonostor 33-50.; Varga Árpád: A váradi káptalan hiteleshelyi működése. In: Művelődéstörténeti tanulmányok. Bukarest, 1980. 20-35.

${ }^{5}$ Részletes ismertetésüket lásd Trócsányi: Kormányhatósági levéltárak 125-148.

${ }^{6}$ Kemény: Notitia.

${ }^{7}$ Beke Antal: Az erdélyi káptalan levéltára Gyulafehérvárt. Bp., 1889-1895. (Kny. a Ttár-ból); Beke: A kolozsmonostori konvent. 
a szerző az erdélyi hiteleshelyi levéltárakban nem kutatott, habár maga is megállapította, hogy „,a teljes feldolgozáshoz persze kívánatos lett volna átvizsgálni az erdélyi hiteles helyek levéltárait és az igen gazdag és sok szempontból fontos pozsonyi káptalani levéltárat is, ez azonban a mai viszonyok között nem volt lehetséges" ${ }^{8}$ A második világháborút követően Erdély hosszú időre kényszerüen kikerült a magyarországi történészek érdeklődési köréből, így az erdélyi történetkutatókra és levéltárosokra maradt a feladat, hogy a requisitorok müködését szabályozó instrukció szövegét közzétegyék és a szekularizált hiteleshelyek kérdéskörét a román kutatókkal is megismertessék. ${ }^{9}$ A konvent szekularizáció előtt vezetett jegyzőkönyveinek regesztáit Jakó Zsigmond tette közzé 1990-ben, e két monumentális kötet bevezetőjében a hiteleshely és levéltára későbbi történetét is felvázolta, megteremtve a további kutatások alapjait. ${ }^{10}$ Újabban Sunkó Attila közölt tanulmányokat és forrásokat a kora újkori erdélyi hiteleshelyekről, de közleményeinek pontatlanságai okán az általa levont következtetések csak igen nagy körültekintéssel és kis részben fogadhatók el. ${ }^{11}$ Ugyanez mondható el Vekov Károly nemrégiben megjelent tanulmányáról is, amely a gyulafehérvári káptalan szekularizáció körüli helyzetét mutatta be. ${ }^{12}$ Szintén az elmúlt években indult el néhai Jakó Zsigmond kezdeményezésére a két erdélyi hiteleshely fejedelemség kori jegyzőkönyveinek regesztákban való közzététele; e munkálat első eredményeként jelent meg rövid bevezetővel a gyulafehérvári káptalan XVI. századi protocollumainak kivonatait tartalmazó kötet. ${ }^{13}$

Dolgozatunk célja a kora újkori közhitelű tevékenység erdélyi sajátosságainak vizsgálata egy olyan intézmény, a kolozsmonostori konvent hiteleshelyének esetében, melynek fejedelemség kori jegyzőkönyvei jórészt

${ }^{8}$ Papp László: A hiteles helyek 5. Az erdélyi hiteleshelyi iratanyag tanulmányozásában bizonyára az akadályozta a tudós piaristát, hogy az 1921-ben elrejtett erdélyi származású levéltárakat csak 1933-ban szállították vissza Budapestre. Erről lásd Lakos János: A Magyar Országos Levéltár története. Bp., 2006. 231.

${ }^{9}$ Jakó: Instrucțiunile 54-56.; Kiss Andrei: Locurile de adeverire 58-67.

${ }^{10} \mathrm{KmJkv}$ I. 88-91., 144-149.

${ }^{11}$ Sunkó: Archontológia 277-327.; Sunkó: A Gyulafehérvári Káptalan 75-110.; Uő: Debreceni János 305-343. Az archontológiai összeállítás alapján a requisitorok „egyéb tisztségeiről” például tévesen, illetve hiányosan állapította meg, hogy „,kötelezően végigjárandó út első állomása a nagyobb kancellária írnoki tisztsége", vagy némely levélkereső egyházi szerepvállalása alapján túl merészen még „,a két hiteleshely szekularizációjának problematikáját” is felvetette. Vö. Archontológia 291-292.

${ }^{12}$ Vekov Károly: A gyulafehérvári káptalan hiteleshelyi tevékenysége és 16. századi szekularizációja. In: Loca credibilia. Hiteleshelyek a középkori Magyarországon (szerk. Fedeles Tamás, Bilkei Irén). Pécs, 2009. 131-141. Vö. Bogdándi Zsolt: Az erdélyi hiteles helyek múködése a szekularizációt követően. In: 700 éves a közjegyzőség Magyarországon (szerk. Rokolya Gábor). Bp., 2008.

${ }^{13}$ ErdKápJkv I. 
fennmaradtak. Lényegében arra próbálunk választ adni, hogy a szekularizáció után világi alapon újjászervezett konvent, amely elnevezését megőrizve Kolozsvárra költözött, hogyan müködött, milyen szerepet töltött be az erdélyi társadalomban, miképpen felelt meg az iratkibocsátás és -megőrzés terén jelentkező elvárásoknak.

A Korai magyar történeti lexikon meghatározása szerint „,azok az egyházi testületek: káptalanok, konventek számítottak hiteleshelynek, amelyek egyfelől természetes v. jogi személyek megkeresésére, másfelől királyi parancsra v. hatósági megbízásra közhitelű okleveleket állítottak ki". ${ }^{14}$ Minthogy a szekularizáció következtében Kolozsmonostorról a szerzetesi közösség szétszéledt, a konvent mint egyházi intézmény megszűnt. Húsz évnyi tétova kísérletezgetés után, az egykori egyházi testület kebelében múködő hiteleshely pótlására létrehozott intézmény pedig már alapvetően világi jellegü lett. Ennek ellenére dolgozatunkban ragaszkodtunk a kolozsmonostori konvent megnevezéshez, noha esetünkben a konvent fogalma nem egyházi testületet, hanem hiteleshelyet jelöl. A fennmaradt adatok alapján ugyanis egyértelmü, hogy a fejedelemség korában a konvent elnevezés alatt hiteleshelyet értettek, és hogy többnyire a kolozsmonostori konvent kifejezés volt használatban. ${ }^{15}$

${ }^{14}$ Korai magyar történeti lexikon (9-14. század). Főszerk. Kristó Gyula. Szerk. Engel Pál és Makk Ferenc. Bp., 1994. 263.

${ }^{15}$ Szabó T. Attila szótárában a konvent szócikknek öt értelmét adta meg, ezekből csak kettő jelenti az egyházi testületet, illetve kolostort vagy rendházat. A többi értelmezés, valamint a felsorakoztatott példák mind a hiteleshelyre, illetőleg a levélkeresői testületre vagy valamelyik requisitorra vonatkoznak. Lásd SzT VII. 199-200.: „1560: benedek uram az vallasnak ideyennis mykor az my anyank az monostori Conventbe az it valo ewreksegek felewl vallast thewth jyelen volt"; ,1586/1629: mind az ket fel erreis ighire magat... hogy az Colosmonostori Conventbennis hasonlokeppen mind ezekreol vallast tesznek, es be irattyak"; „1597: Az Conventeknek lewel arraba az Jozagrol walo privilegiumert f 40". Ugyanígy már a káptalan sem egyházi testületet jelölt, hanem többnyire hiteleshelyet jelentett, sőt olykor még a Kolozsvárra költözött konventet is ezzel a megnevezéssel illették: „1585: mynd az kett fell, kolozúárra be mennyen az kaptalan Eleyben es ezbely dologroll kaptalan pechiety alatt kelljen keozotteok levell... Mikor... az Vitezlo Theke Ferencz es Komjaty Mihall', az penz maradekanak meg adasara, es fell vetelere Convent elejbe mennek, akkor keozteok mas levell kellyen Convent pechiety alatt" (ebben az esetben a konvent és a káptalan is ugyanaz a Kolozsváron müködő hiteleshely). Vö. SzT VI. 138-139. Késői példa arra, hogy még a latin nyelvű oklevelekben is más jelentést kapott, illetve keveredett a konvent és a káptalan fogalma, I. Apafi Mihály 1682. március 10-i levélkerestető parancsa: „Fidelibus nostris egregiis et nobilibus requisitoribus litterarum et litteralium instrumentorum in capitulo Beate Mariae Virginis de Colosmonostra repositorum [...] prescriptas universas litteras in capitulo seu conservatorio vestro repositas ac locatas requirere et reinvenire, requisitarumque et reinventarum tenorem in verissimis paribus sub sigillo vestro capitulari et authentico [...] extradare debeatis." A jelentés szövegében azonban már "quibus receptis nos pretactas literas in sacristia sive conservatorio dicti conventus nostri" szerepel (vö. DF 257522). A jelentésváltozásokról lásd még a 155. jegyzetet. 
Értekezésünkben röviden arra is kitérünk, hogy az egykori Magyar Királyság keleti részén létrejövő államalakulatban melyek lehettek azok az intézmények, amelyek a konvent és a káptalan átszervezéséig, illetve részben már a korábbiakban is átvehették a hiteleshelyi feladatok egy részét. Szót ejtünk tehát az ítélőmesterek, a fejedelmi kancellária, a fogott bírák, a vármegyék „,hiteleshelyi” tevékenységéről, azok jellegzetességeiről. Mindez azért szükséges, hogy megérthessük azokat az átalakulásokat, melyek a requisitorok tevékenysége idején mentek végbe a hiteleshelyi gyakorlatban. A kérdések megválaszolásához elengedhetetlennek tünt a konventet a fejedelemség korában működtető levélkeresők pályájának részletes bemutatása, minthogy az intézmény működése nagymértékben az ő képzettségüktől és egyéniségüktől függött.

A konvent oklevéladó tevékenységének tárgyalásakor végig arra fektetjük a hangsúlyt, hogy a szekularizáció előtti gyakorlathoz képest bekövetkezett változásokat szemléltessük. Arra fogunk törekedni, hogy azokat az okokat is feltárjuk, amelyek a "hagyományos” oklevélkiadásban egyre több, Pálfi István requisitor által felsorolt impedimentumhoz vezettek, és amelyek valójában a levélkeresőknek a fejedelem által fizetett (olykor fizetetlen) hivatalnoki státusából, illetve az ország ügyeiben való fokozottabb igénybevételükből adódtak. Végül kitérünk a konventi kiadványok diplomatikai sajátosságainak bemutatására, a hiteleshely fejedelemség kori levéltárának történetére (elhelyezésére, anyagára, a levéltárrendezésekre) és a konvent protocollumaira.

Kutatásunk alapját 28 protocollum bejegyzései képezték az 1576-1690 közötti időszakból. Minthogy a jegyzőkönyvekbe többnyire teljes szövegű okleveleket másoltak, ezek segítségével a hiteleshelyi tevékenységre vonatkozó következtetéseinket levonhattuk anélkül, hogy más források bevonására is sort kerítettünk volna. A kiadványok vizsgálatát egy-egy családi levéltár alapján végeztük, a requisitorok életrajzaihoz és müködéséhez pedig a konvent Miscellanea állagát, továbbá a gyulafehérvári Batthyaneumban ôrzött konventi és káptalani iratanyagot használtuk fel. Nem kutattuk át tehát a teljes konventi levéltárat, hiszen a dolgozat legnagyobb feladata így is a tekintélyes, több mint 15000 oldalnyi forrásmennyiség áttekintése és feldolgozása volt. Úgy véljük, hogy az esetlegesen előkerülő újabb adatok kiegészíthetnék ugyan az általunk felvázoltakat, de azt alapjaiban nem változtatnák meg.

Részben ez a hatalmas forrásanyag a magyarázata feldolgozásunk végső, lényegében önkényesen kijelölt időhatárának, amely az önálló erdélyi fejedelemség megszünését jelző 1690 -es esztendő. Sem ez az év, de még a konvent 1729-ben végbement egyházi felügyelet alá rendelése nem hozott nagyobb változásokat a hiteleshely szervezetében; a fogyatkozó 
oklevéladó munkát az egyre inkább levéltárszerepet betöltő konventnél továbbra is világi requisitorok végezték. A hiteleshely müködése 1872-ig tart, az intézmény története is ezzel az évvel záródik. Mi azonban csak arra vállalkozhattunk, hogy e jellegzetesen fejedelemség kori képződmény kora újkori működését tárjuk fel, a további - inkább levéltártörténeti - kutatások feladata lehet a hiteleshelyi levéltár XVIII-XIX. századi történetének tisztázása.

A szövegtestben és a jegyzetekben közölt korabeli szövegek átírásakor a teljes átírás és a szintén szélsőségesnek tartott betűhűség közötti józan átmenet biztosítására törekedtünk. Habár különböző korszakokból és sok személy kezétől származó iratokról van szó, úgy döntöttünk, hogy az Erdélyi Történelmi Adatok forráskiadvány-sorozatban alkalmazott elveket követve próbáljuk a szövegeket hozzáférhetőbbé tenni a nem szakemberek számára is.

E munka elvégzéséhez nyújtott segítségükért köszönet illeti meg doktori témavezetőmet, Solymosi Lászlót, opponenseimet, Oborni Terézt és Sipos Gábort, valamint a Debreceni Egyetem Történelmi Intézetének és az Erdélyi Múzeum-Egyesület Kutatóintézetének munkatársait. A téma feldolgozására Jakó Zsigmond professzor biztatott. E kötettel az Ó emléke előtt tisztelgünk. Remélhetőleg sikerül általa a szakmai „felügyelete” alatt eltöltött évek során felhalmozott adósságunkból valamennyit törleszteni. 


\section{A KOLOZSMONOSTORI KONVENT A SZEKULARIZÁCIÓ ELŐTT}

\section{1. A hiteleshelyek kialakulása}

Bár dolgozatunk célja a kolozsmonostori konvent kora újkori hiteleshelyi tevékenységének bemutatása, a szekularizáció után bekövetkezett változások számbavétele, mégis hasznosnak tưnik az intézmény középkori müködésének felvázolása. Ez annál is fontosabb, mert az újkorban végbemenő jelenségek megértéséhez elengedhetetlen a középkori előzmények ismerete.

A hiteleshelyek tevékenységének vizsgálata régóta kedvelt témája a magyar történetkutatásnak, bizonyára azért, mert olyan intézményről van szó, mely a magyar jogfejlődésnek sajátos terméke. A középkor századaiban Nyugat-Európában teljességgel ismeretlen volt az a jelenség, hogy egyházi testületek saját pecsétjük alatt mások ügyeiben bocsássanak ki olyan oklevelet, mely általános elismertségre tartott volna számot. Antik előzmények alapján a romanizált területeken, így elsősorban Itáliában, valamint Németországban közjegyzők, Franciaországban pedig emellett még a városi jegyzők látták el azt a feladatkört, mely Magyarországon a közjegyzők munkáját végző hiteleshelyekre hárult.

A XII. század végétől Magyarországon a székes- és jelentősebb társaskáptalanok magánjogi ügyletek írásba foglalásával, oklevéladással is foglalkoztak. Hitelüknek köszönhetően egyháziak és világiak egyaránt fordultak hozzájuk, hogy ügyeikről oklevelet állítsanak ki. ${ }^{16} \mathrm{~A}$ bizalom irán-

\footnotetext{
${ }^{16}$ A hiteleshelyekre vonatkozóan lásd Eckhart Ferenc: Die glaubwürdigen Orte Ungarns im Mittelalter. In: Mitteilungen des Instituts für österreichische Geschichtsforschung, 1914. 395-558.; Szentpétery: Oklevéltan 74-77., 121-138., 214-222.; Papp László: A hiteles helyek. Továbbá Kőfalvi Tamás válogatott jegyzéke a hiteleshelyek történetét tárgyaló irodalomból: A hiteleshelyi oklevelek egyháztörténeti tanulságai. In: Egyháztörténeti Szemle 1 (2000). 1. sz. 61-64. Újabban lásd Solymosi László német nyelven megje-
} 
tuk abból fakadt, hogy a XI. századtól fogva ezekben az intézményekben végezték az istenítélet szertartását, itt tartották a bíráskodásban bizonyító eszközként alkalmazott tüzesvaspróbákat, s ezek eredményéről feljegyzést is készítettek. A XIII. század elején a bencés, premontrei és lovagrendi konventek is bekapcsolódtak az oklevéladó munkába. ${ }^{17}$

\section{2. A kolozsmonostori konvent hiteleshelyi tevékenysége a szekularizáció előtt}

A kutatások jelenlegi állása szerint Kolozsmonostor apátságát a XI. században alapították. ${ }^{18}$ Alapítójának legnagyobb valószínúséggel I. László királyt tekinthetjük. ${ }^{19} \mathrm{~A}$ korai alapításhoz képest a konvent hiteleshelyi tevékenységéről viszonylag kései adatok szólnak, az első olyan hiteles oklevél, amely egyértelmúen az ilyen jellegű munka eredménye, 1308-ból maradt ránk. ${ }^{20}$ Közvetett források azonban a hiteleshelyi oklevélkiadás korábbi (feltehetően a XIII. század végi) elkezdését valószínűsítik. László erdélyi vajda 1304. szeptember 28-án néhai János alvajda, szolgabírák, továbbá a Clus-i apát és konventje bemutatott oklevelei alapján erősíti meg Miklós comest és testvérét örökjogú földjük birtokában. ${ }^{21} \mathrm{~A}$ kolozsmonostori konvent tehát már a megerősítés kelte előtt állított ki felek megkeresésére oklevelet, talán még a XIII. század utolsó harmadával kezdődően. ${ }^{22}$

A hiteleshely működésének 1339-ig tartó kezdeti szakaszában az oklevéladó tevékenység nem mutatott látványos fejlődést, az oklevélkibocsátás inkább csak alkalmi jelleggel folyhatott. Bizonyára az 1338 őszétől müködő János apátnak tulajdonítható a konventi hiteleshely „felépítése”, az apátok nevében folytatott rendszertelen és kezdetleges oklevéladás megszervezése. ${ }^{23}$ Feltételezhető, hogy a konvent ekkor kapott a királytól közhitelü

lent összefoglalását: Die glaubwürdigen Orte (loca credibilia) Ungarns im 14.-15. Jahrhundert. In: Archiv für Diplomatik 55 (2009). 175-190.

${ }^{17}$ A bencés konventek hiteleshelyi tevékenységének kezdeteiről lásd Solymosi László: $A$ bencés konventek hiteleshelyi oklevéladásának kezdetei. In: Mons Sacer 996-1996. Pannonhalma ezer éve I. Pannonhalma, 1996. 481-498.

${ }^{18} \mathrm{KmJkv}$ I. 21.; Kovács András: Kolozsmonostor. Római katolikus kálvária templom. Erdélyi müemlékek 27. Kolozsvár, 1997. 1-2.

${ }^{19}$ Sipos: Kolozsmonostor 33-34.; Gáll Erwin-Gergely Balázs: Kolozsvár születése. Régészeti adatok a város 10-13. századi történetéhez. Kolozsvár, 2009. 106-107.

${ }^{20}$ Sipos: Kolozsmonostor 38.

${ }^{21}$ CDTrans II. 43. sz.

${ }^{22}$ A többi bencés konvent is ekkortól vette ki igazán részét a hiteleshelyi tevékenységből, lásd Solymosi: A bencés konventek 492.; Sipos lehetségesnek tartja, hogy az oklevéladás már 1288 táján megindult. Lásd Sipos: Kolozsmonostor 37.

${ }^{23}$ Erről bővebben lásd KmJkv I. 33-34.; A kialakulatlan formulákra vö. Sipos: Kolozsmonostor 38 . 
pecsétet hiteleshelyi tevékenység folytatására. Ezután mindjárt az első kiadványok kialakítása magas színvonalú, a megfogalmazásokban nem észlelhető kísérletezés, egyszeriben, készen ültették át a régebbi hiteleshelyeknél már kialakult gyakorlatot. Az oklevelek kiállítása ekkortól egészen a szekularizációig a középkori gyakorlatnak megfelelően lényegében töretlenül folyt. Mivel nem feladatunk a középkori hiteleshelyi tevékenység részletes bemutatása, az alábbiakban csupán ennek főbb jellegzetességeit vázoljuk.

A konvent középkori kiadványainak osztályozásában alapvetően tárgyi és formai szempontok merülhetnek fel. Tárgyi szempontból két fő csoportba oszthatjuk az okleveleket. A fassiók (bevallások) magánjogi jellegűek, míg a relatiókat (jelentések) általában egy-egy közhatóság megbízásából vagy ritkábban a felek kérésére foglalták írásba. Ezt a beosztást jobbára az oklevelek alakja is követi: míg a bevallásokat általában nyílt, pátens formában állították ki, addig a jelentések zártak (clausák) voltak. Ha arra igény volt, a hiteleshelyek bevallásról és jelentésről egyaránt állítottak ki függőpecséttel ellátott kiváltságlevelet.

\section{A bevallások (fassiones)}

A bevallók vagy személyesen, vagy ügyvédvalló levéllel felhatalmazott megbízott által jelenhettek meg a konvent előtt. A bevallásokról kiállított pátensek szerkezete egyszerübb, az intitulatiót többnyire egyből a narratio követi: „Nos conventus monasterii Beate Mariae virginis de Kolosmonosthra memorie commendamus per presentes quod [...]". ${ }^{24} \mathrm{~A}$ nagyobb tekintéllyel bíró privilégiumok esetében a formula eltérő, a protocollumnak szinte minden része megtalálható: „Conventus monasterii beate Marie virginis de Colosmonostra omnibus Christi fidelibus tam presentibus quam futuris, presentium noticiam habituris salutem in omnium salvatore. Ad universorum noticiam harum serie presentium volumus pervenire quod $[\ldots]]^{\prime 2} .{ }^{25}$ A hiteleshely előtt tett bevallások tárgyuk szerint legnagyobb részben a birtokforgalomra vonatkoznak. A megszerzett jószágok védelmére a birtokjogban bekövetkezett bármilyen változást (adományozást, adásvételt, zálogosítást, cserét, egyezséget, végrendeletet stb.) igyekeztek a hiteleshelyekkel írásba foglaltatni a későbbi jogi támadások kivédése érdekében. ${ }^{26}$

\footnotetext{
${ }^{24}$ DL 28045 (1525-ös kiadvány).

${ }^{25}$ DF 27095 (1499. évi oklevél). Hasonló példa 1509-ből: DL 21900.

${ }^{26}$ Dreska Gábor: A pannonhalmi konvent hiteleshelyének müködése a Zsigmond-korban. In: Levéltári Közlemények 68 (1997). 1-2. sz. 5.
} 
A javak azonban sokszor törvénytelen úton cseréltek gazdát. A középkorban gyakran elöfordultak az ún. hatalmaskodások (pusztítások, rablások, egy-egy birtok jogtalan elfoglalása), illetve a birtokok és részbirtokok jogtalan eladományozása (ez nem mindig az uralkodó hibájából történt, ugyanis sokszor hívei magszakadás címén kértek egy-egy olyan birtokot, amelynek tulajdonosa még életben volt, de a nagy távolságok miatt erről nem tudtak). A sértett felek a hiteleshelyen megjelenve tiltakoztak a jogsérelem ellen, és egyúttal a birtokra vonatkozó minden jogukat fenntartották. $^{27}$

A bevallók gyakran oklevelek átírása végett fordultak a konventhez. A jogilag érvényesített hiteleshelyi átirat készítésének elsődleges oka a jogbiztosító eredeti irat megóvása volt. Mielőtt az átírásra sor került volna, a hiteleshelyi szakértők megvizsgálták az oklevelet, hogy ne szerezzenek érvényt hamisítványnak hiteles másolattal. ${ }^{28}$ Oklevélátírásokat hatósági parancsra is végeztek, legtöbbször egy-egy per folyamán az egyik fél által bemutatásra kerülő, bizonyítékként használt okleveleket adtak ki saját levéltárukból.

\section{A külső hiteleshelyi tevékenység - jelentések (relationes)}

A bevallások felvétele és írásba foglalása mellett a hiteleshelyek jelentős szerepet játszottak a bíráskodásban és közigazgatásban is. Eljártak különböző birtokügyletekben (birtokba való bevezetés és iktatás, határjárás, felbecsülés), de a peres ügyek szinte minden mozzanatában is részt vettek. ${ }^{29}$ A mandátumban megnevezett több királyi, illetve Erdély esetében vajdai vagy alvajdai ember (általában környékbeli birtokos) közül egy mint hivatalos kiküldött kiszállt a helyszínre a parancs végrehajtása végett. Ennek tanúbizonyságaként (pro testimonio fidedignum) vele ment a hiteleshelyi kiküldött. Bevezetés és iktatás esetén összehívták az illető birtok szomszédait, akik a helyszínen elmondhatták esetleges ellenvetéseiket. A kiküldöttek még három-négy napig vártak a helyszínen, majd visszatértek a hiteleshelyre, ahol általában a mandátum hátára rávezetett feljegyzések alapján beszámoltak a történtekről. Ha az iktatástól számított tizenöt napon belül nem történt tiltakozás, akkor kiállíthatták az oklevelet. Az ellentmondókat tizenötöd napra idézték a parancslevélben megnevezett bíróság elé, ahol tisztázhatták magukat. Ha a végrehajtás nem egyszerü mandátum, hanem egy pert lezáró ítéletlevél (litterae adjudicatoriae) alapján folyt, akkor érvé-

\footnotetext{
${ }^{27}$ Sipos: Kolozsmonostor 39.; Lásd még az első újkori gyulafehérvári protocollum (Adam primus homo) középkori bejegyzéseit: KápJegyz (MOL F2) I. p. 1-2.

${ }^{28}$ Sipos: Kolozsmonostor 40.

${ }^{29}$ Kumorovitz: A leleszi konvent 3-4.
} 
nyesen csak kivont karddal - evaginato gladio - lehetett tiltakozni. ${ }^{30}$ Ebben az esetben a mandátum mellett a pecsétnyomó felső részével (cum capite sigilli) megpecsételt ítéletlevelet is visszaküldték az illetékes szervnek.

A perek előkészítő szakaszaiban különböző fokú bíróságok kérték a hiteleshelyek közreműködését. A felperes panaszainak jogosságát a két hivatalos megbízott (vajdai/alvajdai ember - hiteleshelyi küldött) útján folytatott kivizsgálás által tisztázták. A kiküldöttek nyilatkozatokat kértek az ügyről tudó egyénektől, majd a vallatás (inquisitio) végeztével oklevelet állítottak ki. De hiteleshelyek tanúskodtak határjárás (reambulatio metarum) vagy eskütétel esetén is. ${ }^{31}$

A jelentések belső szerkezete a bevallásokhoz viszonyítva összetettebb. A címzést tartalmazó kezdő rész után a teljes szövegében vagy tartalmilag átírt parancslevél következik, végül az ügyintézés részletes leírása zárja a contextust. ${ }^{32} \mathrm{~A}$ dátumot mindig a kiszállásnak az oklevélben feltüntetett időpontjához viszonyítva adták, sikertelen iktatás esetén például: „datum sexto die diei repulsionis". ${ }^{33}$ Az oklevél hátlapján található a címzés, illetve az ügy rövid összefoglalása.

A hiteleshelyi kiadványokat formájuknak megfelelően pecsételték, és erre a corroboratióban meghatározott formulákkal utaltak: „in cuius rei memoriam firmitatemque perpetuam presentes litteras nostras privilegiales pendentis et autentici sigilli nostri munimine roboratas duximus concedendas" ${ }^{34}$ A privilegiális oklevelekre függőpecsét került, amelyet selyem- vagy kenderzsinórral erősítettek a pergamen felhajtott aljához. Az egyszerübb formájú pátens bevallások hátlapján hártya- vagy papírszalaggal átfüzött pecséteket találunk. Az általában zárt jelentéseket úgy pecsételték meg az összehajtott oklevél hátán, hogy a pecsét mindkét oldalt lezárja. ${ }^{35}$

A kolozsmonostori konvent több mint 3000 kiadott és máig fennmaradt oklevele jelzi a hiteleshely működésének jelentőségét. ${ }^{36}$ Ez azonban csak egy töredéke a kiállított oklevélmennyiségnek, hiszen a középkorban vezetett 25 protocollumba ennél jóval több bejegyzést másoltak. Ez a tekintélyes iratmennyiség a bizonyság arra, hogy a konvent a középkor

\footnotetext{
${ }^{30}$ KápJegyz I. p. 9-10.

${ }^{31}$ Sipos: Kolozsmonostor 42.

${ }^{32}$ Kemény cs csombordi levéltára a KvNLt-ban, vol. I. nr. 35.

${ }^{33}$ KápJegyz I. p. 10.

${ }^{34}$ DF 261151.

${ }^{35}$ Sipos: Kolozsmonostor 47.

${ }^{36}$ A középkori Magyarország levéltári forrásainak internetes Adatbázisa (DL-DF) - http:// mol.arcanum.hu/dldf/opt/a101129htm?v=pdf\&a=start
} 
évszázadaiban Erdély legjelentősebb oklevél-kibocsátója volt. ${ }^{37}$ A középkori oklevelek teljességre törekvő tanulmányozása talán még finomíthatná a képet, melyet az eddigi irodalom alapján a konvent szekularizáció előtti hiteleshelyi tevékenységéről alkothattunk, de azt alapjaiban valószínűleg nem változtatná meg.

${ }^{37}$ A DL-DF adatbázis nyilvántartásai alapján a konventet az erdélyi káptalan követi 2341 oklevéllel (ezek egy része hamisítvány vagy késői átiratban fennmaradt, gyanúsnak tekinthető kiadvány). Az erdélyi káptalan középkori jegyzőkönyvei viszont nagyrészt elpusztultak, ezért nehéz eldönteni, hogy a konvent vagy a káptalan volt Erdély legtermékenyebb oklevéladó intézménye. Erdély északi részén nagyobb számú volt a kis- és középbirtokosság, illetve délen a káptalan múködési területéből kiesett a szászság és nagyobbrészt a székelyek is, ezért vélhetően inkább a konventet tekinthetjük az országrész számszerűleg legjelentősebb iratkibocsátójának. A középkori hiteleshelyi kiadványokról Kőfalvi Tamás végzett számításokat, lásd A hiteleshelyek mint a magyarországi közjegyzőség elózményei. In: 700 éves a közjegyzőség Magyarországon. A 2008. november 27-i jubileumi konferencián elhangzott előadások szerkesztett változata (szerk. Rokolya Gábor). Bp., 2008. 16-19. 


\section{AZ ERDÉLYI HITELESHELYEK A SZEKULARIZÁCIÓ UTÁN}

Az 1556-57-ben bekövetkezett szekularizációig az erdélyi hiteleshelyek oklevéladó tevékenysége a középkori magyarországi gyakorlatnak megfelelően lényegében változatlanul folyt. ${ }^{38} \mathrm{~A}$ szekularizáció következtében birtokaikat, személyzetüket és nem utolsósorban tekintélyüket is vesztett egyházi intézmények funkciói közül egyedül a hiteleshelyire vonatkozóan maradt továbbra is valós társadalmi igény. A rendek érdekei is leginkább a hiteleshelyeken őrzött jogbiztosító levéltári anyag megóvásához és zavartalan használatához füződtek. Az erdélyi hiteleshelyek működésének a magyarországi gyakorlattól elváló, külön útja az 1557. évi tordai országgyűlés után kezdődött, amikor a hiteleshelyi levéltárak őrzését „kiváló nemes emberek"-re, requisitorokra vagy magyarul levélkeresőkre, utóbb elterjedt megnevezésük szerint „káptalanokra és konventekre” bízták. ${ }^{39}$ Úgy tünik azonban, hogy maguk a rendek sem voltak meggyőződve az újonnan létrehozott levélkeresői szolgálat életképességéről, illetve a requisitorok feladatának - mint nevük is mutatja - csak a hiteles másolatok kiállítását, a jogbiztosító iratok előkeresését tekintették. Ezért 1557-ben, a hiteleshelyi tevékenység „rendezésével” egy időben, az országgyűlés arról is intézkedett, hogy a királyi, illetve a vajdai emberek is törvényesen végezhessék azt a munkát, amely addig kizárólag a hiteleshelyek feladatkörébe tartozott. Habár ez az intézkedés csak a Partiumban élőkre vonatkozott, ${ }^{40}$ tény az, hogy az iktatásokat, valamint a többi, korábban a hiteleshelyek feladatkörébe tartozó eljárást a vajdai küldöttek végezték, akik közül az egyik esetenként kancelláriai íródeák, társa pedig helybéli, a helyi viszonyokat jól

\footnotetext{
${ }^{38}$ Szentpétery Imre: Az erdélyi okleveles gyakorlat jellege. In: Turul 1941. 1-2. füzet. 3.

${ }^{39}$ A hiteleshelyekre vonatkozó országgyűlési végzésekről lásd EOE II. 81., 89., 107., 176., 340.; Trócsányi Zsolt: Törvényalkotás 212-215.

${ }^{40} \mathrm{Vö.} \mathrm{106.} \mathrm{sz.} \mathrm{jegyzet.}$
} 
ismerô nemes volt. ${ }^{41} \mathrm{Az}$ általuk kiállított jelentések formulái megegyeznek a korábbi hiteleshelyi oklevelekben használtakkal, ezeket a kiadványokat azonban csak saját gyưrüspecsétjükkel erősíthették meg, ennek viszont - a kortársak szemében - nem lehetett akkora jogbiztosító ereje, mint egy-egy autentikus, az írástudatlanok számára is közismert pecséttel rendelkező káptalan vagy konvent által megerősített oklevélnek.

\section{1. A gyulafehérvári hiteleshely a szekularizáció után}

\section{A gyulafehérvári levélkeresők múködésének első korszaka (1557-1575)}

A születő erdélyi fejedelemség világi értelmiségének nagy része az egyházi intézmények szárnyai alatt erősödött meg annyira, hogy átvehesse az egyház funkcióinak azon részeit, amelyekre a társadalom továbbra is igényt tartott. A gyulafehérvári káptalani levéltár őrizetére kijelölt személyek kivétel nélkül a korábban kanonoki stallumot élvezők vagy a hiteleshelyi kancellárián szolgálatot teljesítők közül kerültek ki, hiszen ők voltak birtokosai azoknak a gyakorlati ismereteknek, melyek hiányában a hiteleshelyi levéltárban és munkában való tájékozódás lehetetlen lett volna. A reális társadalmi szükséglet által létrehozott levélkeresői szolgálat ellátói, a requisitorok először 1559-ben jelennek meg a forrásokban, ${ }^{42}$ de ekkor még - és az elkövetkező években is - csak a káptalani levéltárból írnak át hatósági utasításra vagy magánszemélyek kérésére okleveleket. A fejedelmi pecséttel megerősített másolatokért a korábban szintén kanonoki címet viselő Csáky Mihály kancellár felelt; ezzel kezdődik a kialakulóban levő fejedelmi kancelláriával való szoros kapcsolat, amely a gyulafehérvári hiteleshely működését végig jellemezte. ${ }^{43}$ Úgy tünik, hogy a birtokaitól

\footnotetext{
${ }^{41}$ A hatósági kiküldöttek megnevezése a fejedelemség korában homo vaivodales vagy regius. Vö. az 1590-es évek első felében vezetett kisebb kancelláriai formuláskönyvben (jelzete: F15/ XII.) található bejegyzésekkel, pl. „Mandatum ad vaivodalem ut attestantem in suam convocet presentiam attestarique faciat” (p. 5), "Novum judicium ad vaivodales cum evocatione” (p. 8), „Preceptoria ad vaivodales ut relatorias errore plenas super introductione et statutione confectas corrigat" (p. 14), „Preceptoria ut vaivodales procuratoriam constitutionem recipiant" (p. 48). További, magyar nyelvű példák: SzT XI. 212-214., XIII. 1022.

${ }^{42}$ DL 1688. Valószínúleg 1559-ben neveztek ki Gyulafehérvárra levélkeresőket, mert 1558 őszén még kijelölésüket sürgeti az országgyűlés, 1560-ban viszont már csak Kolozsmonostorra kérnek requisitorokat. Lásd EOE II. 107., 176.

${ }^{43}$ A fejedelmi korszakban müködő levélkeresők tekintélyes része egy időben teljesített szolgálatot a hiteleshelyi és a fejedelmi kancellárián, mindkét helyen a fejedelmi parancsok végrehajtóiként tevékenykedtek. Jó példa erre az 1588-1599 között káptalani requisitor, Balásfi János, aki ugyanakkor a nagyobb kancellárián is írnokoskodott. Róla lásd Bogdándi: Balásfiak 807-812.
} 
megfosztott káptalan levéltárának kezeléséhez és a fejedelmi kancellária megszervezéséhez egyaránt a káptalan szárnyai alatt nevelkedett írástudókra volt szüksége az Erdélybe került királyi, majd fejedelmi udvarnak. Talán nem tévedünk, ha a szekularizáció utáni években működő káptalani levélkeresők kiválasztását - protestánssá lett kanonoktársai köréből - a kancellária megszervezését is véghezvivő, külföldön is tanult Csáky Mihály személyéhez kötjük. ${ }^{44}$

\section{A gyulafehérvári hiteleshely első levélkeresői ${ }^{45}$}

A feltehetően jogi ismeretekkel rendelkező Mosdósi Ambrus magister 1555-ben még dékánkanonoki címet visel, 1559-1566 között a requisitorság mellett a tizedek erdélyi főarendátora is ${ }^{46}$ Dékánként ő sáfárkodott a káptalani javadalmakkal, és ebben a tisztségében szerzett tapasztalatai is közrejátszhattak abban, hogy őt bízták meg a fejedelmi jövedelemmé vált tized adminisztrálásával is. ${ }^{47}$ Valószínűleg a szekularizált „,káptalan” vezetését is ő láthatta el, erre utalnak az általa ellenőrzött és kijavított oklevelek. ${ }^{48}$ Mosdósi képzettségéről csak bizonytalan adataink vannak. Talán vele azonosíthatjuk azt a Ambrosius Eeles de Mosdost, aki a bécsi egyetem magyar natiójának anyakönyvében 1538-ban szerepel. ${ }^{49}$ A királyi jövedelmek számbavételére Erdélybe rendelt Bornemisza Pál veszprémi püspök a történelmi érdeklődésű Georg Werner magyar kamarai tanácsoshoz 1555-ben intézett levelében Mosdósi Ambrus magistert azok közé sorolja,

\footnotetext{
${ }^{44}$ Csáky Mihály származásáról, életútjáról és udvari szerepéről lásd Jakó Zsigmond: Csáki Mihály (1492-1572) erdélyi kancellár származásáról. In: Társadalom, egyház, művelődés. Tanulmányok Erdély történelméhez. Bp., 1997. 91-96.; Horn Ildikó: Tündérország útvesztői. Tanulmányok Erdély történelméhez. Bp., 2005. 23-32.; Oborni Teréz: Izabella királyné erdélyi udvarának kezdetei (1541-1551). In: Történelmi Szemle 2009/1. 38-39.; A káptalani dékánkanonokok jegyzékében 1532-től szerepel. Lásd Vekov: Alba Iulia 7. sz. melléklet. Csáky halála után a káptalani másolatok kiállításáért utódja, Forgách Ferenc felelt, a hiteleshely és a fejedelmi kancellária közötti szoros együttműködés tehát továbbra is érvényben volt, vö. DL 36931.

${ }^{45}$ Vö. ErdKápJkv VIII/1. 12-18.

${ }^{46}$ ErdKirKv VII/1. 68. sz.; 1559-es adat: DL 36910, 1560 áprilisában kelt nyugtáját közölte Vass Miklós: Székely oklevelek a XVI. századból. Első közlemény. In: Történelmi Tár 1910. 128.; 1566. évi adat: DL 36605.

${ }^{47}$ A középkori dékánkanonokok feladatai közé tartozott az egyházi testületet illető tized begyűjtése is. A dékánok teendőiről lásd Solymosi László: Az egri káptalan dékánválasztási statútumai a XV. századból. In: Levéltári Közlemények 63 (1992). 1-2. sz. 143.; Fedeles Tamás: A pécsi székeskáptalan személyi összetétele a késő középkorban (1354-1526). Pécs, 2005. 59-61.; A tizedarendátorok munkájáról, a fejedelemség kori tizedigazgatásról lásd Ember Győző: Az újkori magyar közigazgatás története Mohácstól a török kiüzéséig. Bp., 1946. 486-494.

${ }^{48}$ DL 38760: 1560-ban kelt átírás szövege alatt: „Lecta et correcta per me Ambrosium Mosdossi".

${ }^{49}$ Schrauf Károly: A bécsi egyetem magyar nemzetének anyakönyve 1453-tól 1630-ig. Magyarországi tanulók külföldön IV. Bp., 1902. 192.
} 
akik képesek összegyűjiteni a gyulafehérvári székesegyház történetének forrásait. ${ }^{50} \mathrm{Ez}$ az adat is azt bizonyítja, hogy Mosdósi amellett, hogy alaposan ismerte a káptalani levéltárat, rendelkezett azokkal az ismeretekkel, amelyek lehetővé tették az oklevelek történeti forrásként való feltárását. Levélkeresőként említik 1565. december 10-én, amikor János Zsigmond fejedelem egyebek mellett a káptalani levéltárban teljesített szolgálataiért bőkezű adományban részesítette. ${ }^{51}$ Mosdósi levélkeresőként utoljára 1568-ban szerepel, talán e tájban következhetett be halála. ${ }^{52}$ Származásáról csak feltételezhetjük, hogy talán a Somogy megyei Mosdósról sodorta a török veszedelem a távoli Erdélybe. Az egykori dékánkanonok családjáról csak annyit tudunk, hogy Csoronk Ilona nevü özvegyétôl egyetlen fia, János maradt. ${ }^{53}$

Dombai Benedeket 1559-1569 között, korábbi klerikussága bizonyságaként, a káptalan szétszéledése után is hosszú ideig helyettes őrkanonokként (subcustos) emlegetik a forrásokban, és ezzel párhuzamosan, feltehetően 1573-ig levéltárosi feladatokat is teljesített. ${ }^{54}$ A szekularizáció előtt az őrkanonok helyetteseként annak feladatait láthatta el, tehát őrizte a székesegyház liturgikus felszereléseit, kegyszereit, a káptalani pecsétet és a levéltárat..$^{55} 1556$ után azonban a káptalani kiadványok megerősítésére használt pecsétnyomó már nem lehetett kezénél, azt bizonyára az ebben az évben Erdélyből távozó Bornemisza Pál püspök vagy kíséretének valame-

\footnotetext{
${ }^{50}$ Radvánszky Béla: Történelmi levelek a Hédervári levéltárból (második közlemény). In: Történelmi Tár. Bp., 1880. 686-587. (téves lapszám!); Ugyanebben az évben kelt Bornemisza levele a káptalanhoz, melyben elrendelte az erdélyi egyházmegye és a székesegyház történetére vonatkozó források összegyưjtését, erre a legalkalmasabb személyeknek Báthai Máté magistert, Mosdosy Ambrus magistert és Albert magister őrkanonokot nevezte meg. Lásd Entz Géza: $A$ gyulafehérvári székesegyház. Bp., 1958. 187-188.

${ }^{51}$ Bánffy cs lt az ENMLt-ban (a KvNLt ôrizetében). Függőpecsétes oklevelek nr. 19.; Ugyanebben az évben a protestánsok elfoglalták a székesegyházat, a maradék katolikus papságot pedig elüzték. A továbbra is müködő requisitorok már valószínűleg valamelyik új hit követői lehettek. A levélkeresők őrizetére bízott káptalani kincstár egy részének átadásakor Mosdósinak már felesége is volt. Lásd János Zsigmond 1565. március 1-jén kiállított nyugtáját Szabó Károly közlésében, téves címmel (Nagy-váradi káptalan XVI. századi egyház kincsei). In: Archaeologiai Értesítő XII (1878). 261-262. Az oklevelet felhasználta Vekov Károly, de a közlést tévesen Deák Farkasnak tulajdonította, lásd Egy erdélyi püspök és a gyulafehérvári székesegyház kincstára. In: Emlékkönyv Jakó Zsigmond születésének nyolcvanadik évfordulójára. Kolozsvár, 1996. 546.

${ }^{52}$ DL 36590.

${ }^{53} \mathrm{KmProt}$ VII. f. 90v-91 .

${ }^{54}$ DL 1688, ErdKápJkv VIII/1. 218. sz.; 1559-ben oltárigazgatóként és requisitorként szerepel lásd DL 36910.

${ }^{55}$ Az őrkanonokok feladatairól lásd Fedeles Tamás: A pécsi székeskáptalan személyi összetétele a késő középkorban (1354-1526). Pécs, 2005. 56-57.
} 
lyik tagja vihette magával. ${ }^{56}$ Rokonságához tartozhatott az 1590-es években a fejedelmi nagyobb kancellárián íródeákként tevékenykedő Dombai Máté. ${ }^{57}$

Az 1559-ben káptalani requisitornak nevezett, feltehetően délszláv származású, magyargáldi birtokos, Radicsics János 1549-ben már a káptalan jegyzőjeként jelenik meg, és ezt a tisztségét a szekularizációig bizonyíthatóan viselte. ${ }^{58} 1565$-ben, a káptalani kincstár egy részének János Zsigmond részére való átadásakor még levélkeresőként szerepelt, és 1566-ban is a káptalannál tevékenykedett, de később már nem találkoztunk a nevével. ${ }^{59}$ Radicsics is jó példa arra, hogy a kialakulóban levő államalakulat megszervezéséhez és müködtetéséhez nélkülözhetetlenek voltak - az egykori királyság többi részéről menekült írástudók mellett - a helyi viszonyokat jól ismerő, tapasztalt deákok. 1559-től a káptalan kancelláriájánál alapos gyakorlatot szerzett Radicsics már az ítélőszék egyik ülnöke, és ebben a tisztségében találjuk 1566-ban is. ${ }^{60}$

Az 1567-ben, majd 1573-ban káptalani requisitor és szintén volt pap Verőczei János valószínúleg rokonsági kapcsolatban állhatott az 1544-1545-ben hunyadi főesperesként, 1546-ban dékánkanonokként említett Verőczei Miklóssal, és feltehetően az ő révén kerülhetett már korábban a hiteleshelyi kancelláriára. Ugyanebben az időszakban, hihetőleg megszakítás nélkül 1568-1573 között Szentmihályi Lőrinc papot is a hiteleshely levélkeresőjeként emlegetik, de ő egyidejűleg a fejedelem gyulafehérvári udvarbírói hivatalát is viselte. ${ }^{61}$ János Zsigmond fejedelem requisitorként teljesített szolgálataiért neki adományozta a korábban a székesegyházi egyik oltárigazgatósághoz tartozó, a szekularizációval a kincstárra háramlott gyulafehérvári házat. Ebből az adatból arra is lehet következtetni, hogy a requisitorok a fejedelem familiárisaiként szolgáltak, levéltárosi munkájukat esetenként egy-egy birtokkal és nem rendszeres, pontosan meghatározott fizetéssel jutalmazták. A levélkeresést amolyan mellékfoglalkozásnak tekintették, és feltehetően egyedül lelkiismeretüktől függött, hogy - lényegében alkalminak tekinthetó - munkájukat miként végezték.

\footnotetext{
${ }^{56}$ A Bornemisza Pál által Gyulafehérvárról elvitt kegyszerekről lásd Entz Géza: A gyulafehérvári székesegyház. Bp., 1958. 143.

${ }^{57}$ Trócsányi: Központi kormányzat 190.

${ }^{58}$ Radicsics János 1549-ben és 1555-ben szerepel káptalani jegyzőként a Vekov által összeállított jegyzékben. Lásd Vekov: Alba Iulia (a kötet végén levő 7. számú melléklet).

${ }^{59}$ 1566-os említése: DL 36605.

${ }^{60}$ DL 36605.

${ }^{61}$ ErdKirKv VII/1. 57., 58., 96., 200. sz.
} 


\section{A gyulafehérvári levélkeresők oklevelei a hiteleshely újjászervezéséig (1575)}

A gyulafehérvári hiteleshely oklevéladó tevékenységében e rövid időszakon belül is két korszakot különíthetünk el. A tartalmi szempontból meglehetősen egyhangú oklevelek, melyek kizárólag oklevélátírások, feltehetően 1571-ig, Csáky Mihály kancellárságának végéig a választott király nevében keltek. A gyulafehérvári hiteleshely saját nevében való oklevélkiadása tehát szünetelt. Ha a perek során valamelyik fél részére a káptalani levéltárból másolatot igényeltek, János Zsigmond utasította az általa kinevezett requisitorokat, hogy keressék meg a sekrestyében az oklevelet, melynek szövegét a fejedelem pecsétjével megerősített oklevélbe foglalták. Ezekért a kiadványokért - csakúgy, mint a fejedelmi kancellárián keltekért - Csáky Mihály felelt, erre utal a levélkerestető parancsba foglalt kitétel, hogy az átírt oklevelet „requisitorumque et reinventorum tenores in transsumto literarum nostrarum per reverendum Michaelem Chyaky cancellarium et secretarium nostrum fidelem sub sigillo nostro [...]" állítsák ki. ${ }^{62} \mathrm{E}$ meglehetősen nehézkes eljárással készült átírásokat a requisitornak kinevezett dékánkanonok, Mosdósi Ambrus ellenőrizte. ${ }^{63}$

1571-től, Forgách Ferenc kancellárságának időszakában egyszerüsítették az átírások kiállítását, a gyulafehérvári levélkeresők ezentúl testületként, saját nevükben adták ki okleveleiket. A hiteleshely azonban továbbra sem rendelkezett saját pecséttel, ezért az átiratokat a nagyobb kancellária pecsétjével (sub sigillo magnificentiae vestrae maioris cancellariae) erősítették meg. ${ }^{64} \mathrm{Az}$ így megszerkesztett oklevelek szövegét feltehetően az egyik levélkereső ellenőrizte, és a kancellár felelt a kiadványokért, amire az oklevelek megfogalmazása is utal: „in transsumpto presentium literarum nostrarum sub sigillo Illustris. magnificentiae vestrae per manus magnifici domini Francisci Forgach de Ghymes cancellarii et secretarii [...] dedimus et emanari fecimus". ${ }^{65}$ Habár az oklevéladás a korábbi időszakhoz képest valamelyest egyszerúsödött, és a felsorakoztatott adatok szerint a gyulafehérvári hiteleshely a fejedelmi kancelláriával szoros kapcsolatban, topográfiailag is közvetlen szomszédságában működött, az átiratok kiállítása elég hosszú időt vett igénybe. 1572-ben például, Báthory István erdélyi vajda szeptember 16-án kelt levélkerestető parancsára a requisitorok egy hónap elteltével állították ki az átiratot. ${ }^{66}$

\footnotetext{
${ }^{62}$ DL $1688,36590$.

${ }^{63}$ 1560-as adat: „Lecta et correcta per me Ambrosium Mosdossi” (DL 38760).

${ }^{64}$ DL 73623.

${ }^{65}$ DL 36931.

${ }^{66}$ DL 73623. Egy 1573-ban kelt átirat kiállításához már szinte két hónapra volt szükség, lásd ErdKápJkv VIII/1. 218-219. sz.
} 


\section{2. A váradi hiteleshelyek a szekularizációt követően}

Váradon a középkorban a székeskáptalan mellett a váradelőhegyi prépostság, majd társaskáptalan is folytatott hiteleshelyi tevékenységet. ${ }^{67} \mathrm{~A}$ váradi székeskáptalan hiteleshelyi levéltárát 1557-től kezdve, a kanonokok távozása után a váradelőhegyi Szent István káptalan őrizte, s minthogy már azelőtt is bocsátott ki okleveleket saját pecsétje alatt, átvette a váradi hiteleshely teendőit is. ${ }^{68}$ Adatok hiányában nehéz eldönteni, hogy miért maradhatott meg a társaskáptalan Váradon és miért tarthatta meg birtokait még néhány évig. ${ }^{69}$ Tény, hogy a partiumi nemességnek érdekében állott a hiteleshelyi levéltárakban őrzött jogbiztosító iratanyag megőrzése és az oklevéladó tevékenység zavartalan folytatásának biztosítása. Emellett bizonyára hozzájárulhatott a káptalan és a hiteleshelyi tevékenység fenntartásához, hogy 1558-ban az országgyưlés a váradi várat szánta Izabella királyné székhelyének, és bizonyos jelek arra is utalnak, hogy Izabella és udvara valóban Váradon is tartózkodott egy ideig. ${ }^{70}$ A feltehetően már 1559-ben váradi kapitánynak kinevezett katolikus Báthory Istvánnak is lehetett szerepe a társaskáptalan védelmében, és talán az sem véletlen, hogy éppen az ő bécsi rabsága idején (1565-1567) üzték el a társaskáptalannak a katolikus hithez ragaszkodó tagjait. ${ }^{71} 1566$-ban, a márciusban tartott tordai országgyưlés végzése értelmében, ${ }^{72}$ a Szent István káptalan tagjainak nagy része távozott Váradról, s még ugyanabban az évben - a helyben maradt, protestánssá lett kanonokok közül - Kanizsai János és Fóris papok, valamint Bihar vármegye nótáriusa és egy másik választott világi kapott megbízatást a hiteleshelyi teendők végzésére. ${ }^{73}$

\footnotetext{
${ }^{67}$ Bunyitay II. 27-33., 208-217., 388-403.

${ }^{68}$ Bunyitay I. 425-443.

${ }^{69}$ Uo. I. 428.

${ }^{70}$ Balogh Jolán: Varadinum. Várad vára. I. Bp., 1982. 40.; EOE II. 88.

${ }^{71}$ Az eseményekről lásd Kruppa Tamás: Nagyvárad jelentősége a Báthoryak müvelődés- és valláspolitikájában. In: Századok 139(2005). 4. sz. 945-946. A hagyomány az országos főkapitányi tisztséget viselő Hagymási Kristófnak tulajdonította a váradi rombolásokat és a katolikusok elüzését. Lásd Horn Ildikó: Hit és hatalom. Az erdélyi unitárius nemesség 16. századi története. Bp., 2009. 177-178.

${ }^{72}$ EOE II. 303: „Az váradi káptalannak ő felsége ez jövő virág vasárnapot hagyta, kik ha meg akarnak térni, házakban, szőlőjökben, marhájokban, jószágoktól el válva, kiket ő felsége magának akar tartani, békességvel megmaradhatnak; ha penig az istennek ígéjét nem akarják venni, személyekben marhájokkal egyetembe valahova akarnak menni, szabadon elbocsáttassanak."

${ }^{73}$ EOE II. 327: 1566 decemberében a következőket határozzák: „a váradi káptalan helyébe mért hogy azok megrontattanak az ő bálványozásoknak okáért, ez dologért az nemességnek igazsága meg ne fogyatkozzék, sőt az Erdélyországnak módjához képest tartassék más két pap Kanisai János és Foris pap, kit most is ugyan ott Váradon vagynak, ezek mellé választassék egy jámbor, tudós és tökéletes ember, az vármegye notariusával egyetemben, kik az
} 
A fejedelemség korában Váradon tevékenykedő levélkeresők meglehetősen hézagos jegyzékét áttekintve néhány érdekes következtetésre juthatunk. ${ }^{74}$ Részben az ő esetükben is megfigyelhető a vármegyével való szoros kapcsolat, amely a konventnél és a gyulafehérvári káptalannál is észlelhetô, másrészt olyan esetekkel is szembesülhetünk, melyekre a váradi káptalannál nem is számítanánk. Amellett, hogy valamelyik levéltáros Bihar vármegye nótáriusi hivatalát is viselte, ${ }^{75}$ a váradi requisitorok, úgy tünik csak ritkán kerültek valamelyik központi hivatal kancelláriájára, megmaradtak „vidéki” értelmiséginek. Váradi Pál deák, aki 1569-1570 között volt bizonyíthatóan váradi requisitor, biztosan nem azonosítható az ugyanebben az időszakban a fejedelmi nagyobb kancellárián jegyzőként szolgáló névrokonával. ${ }^{76} \mathrm{E}$ két tisztség egyidejű betöltése nehezen is volna elképzelhető, noha a későbbiekben bemutatásra kerülő kolozsmonostori példák alapján egyértelmü, hogy a hivatalok halmozása ebben az időszakban sem számított szokatlannak.

\section{A váradi requisitorok által kiadott oklevelek}

Az előbbiekben felvázolt történeti áttekintésből is nyilvánvaló, hogy a váradi hiteleshely sorsa - az erdélyi káptalanéhoz s mint látni fogjuk, a kolozsmonostori konventéhez képest - másként alakult. A társaskáptalan feloszlatása után a hiteleshelyi tevékenység csak rövid ideig szünetelhetett. Már 1567 folyamán újra beindult az oklevéladás, amely nem csupán az átiratok kiadására szorítkozott. ${ }^{77} 1568$ márciusában János Zsigmond az általa kinevezett levélkeresőkhöz, Kristóf paphoz, Albert deák Bihar vármegyei nótáriushoz, váradi Sándor Gergelyhez és Budai Simon deákhoz címezte iktatást elrendelő parancslevelét, amelyre a jelentést csaknem egy év elteltével, 1569 januárjában állították ki ${ }^{78}$ Gyér adataink alapján nem állíthatjuk azt, hogy Váradon az oklevéladás általában ilyen időigényes tevé-

leveleket őrizik oltalmazzák és minden levél keresésinek, kiadásának és törvény szerint való executioknak az ő felsége parancsolatjára, gondját viseljék, és önnön pecsétek alatt s felségnek minden dolgokat híven megirjannak."

${ }^{74}$ A Bunyitay által összeállított névsort lásd Bunyitay IV. 129. Vö. Bogdándi: A váradi hiteleshely 104-116.

${ }^{75}$ 1569-ben Albert deák requisitor és vármegyei jegyző (KvNLt, Wesselényi lt, XVI. századi oklevelek, 1. doboz); Váradi Lukács deák 1587-1595 között levélkereső, 1586-88-ban vármegyei jegyző (ErdKirKv VII/3. 724., 835., 1385. sz.).

${ }^{76}$ ErdKirKv VII/1. 167., 182., 219. sz.

${ }^{77}$ Erre utal az 1566. decemberi országgyúlési végzés (lásd 73. jegyzet), illetve a váradi requisitorok által kiállított oklevelek szövegezése is különbözik a gyulafehérváritól, míg azok „requisitores et conservatores literarum"-ok, a váradiak ,judiciarum deliberationum et legitimorum mandatorum regiorum executores"-ek is.

${ }^{78}$ ErdKirKv VII/1. 50., 74. sz. 
kenységnek számított (ennek ellentmondanak a néhány nap alatt kiállított oklevelek), de feltehetően a négy requisitor időnként nehezen tudott eleget tenni a hiteleshelyi feladatoknak, ezért olykor egy-egy oklevél kiállítása több időt vehetett igénybe. ${ }^{79} \mathrm{~A}$ nehézkes ügyintézés magyarázata lehet az is, hogy a váradi hiteleshely oklevéladó „,szolgáltatásait” nagy terület, lényegében az egész Partium lakossága igénybe vehette, s bizonyára ennek a - középkorihoz képest megfogyatkozott létszámú és más feladatokat is ellátó - kancelláriának lehetett a későbbiekben is a legnagyobb forgalma az erdélyi fejedelmek fennhatósága alá került hiteleshelyek közül.

További kutatások talán majd arra is magyarázattal szolgálhatnak, hogy miért éppen Váradon szervezték újjá elsőnek a világi személyzettel múködő hiteleshelyet. Bizonyára a kiterjedt terület lakosságának szüksége volt egy megbízható, évszázados hagyományokkal rendelkező iratkibocsátó szervre, melyet Gyulafehérváron ideig-óráig részben a fejedelmi kancelláriával próbáltak helyettesíteni.

A váradi levélkeresők okleveleiket eleinte saját nevükben, testületként állították ki, és saját gyűrűspecsétjeikkel erősítették meg. ${ }^{80} \mathrm{~A}$ káptalani pecsét hiányában - melyet talán valamelyik távozó kanonok vihetett magával - ilyen módon megszerkesztett okleveleknek azonban nem lehetett akkora hitelük, mint egy autentikus pecséttel megerösített kiadványnak. Erre a helyzetre érdekes és a fejedelmi kancelláriához való kötődés szempontjából sokatmondó megoldás született. A fejedelem által kinevezett levélkeresők 1569 áprilisában még saját pecsétjeikkel erősítették meg oklevelüket, 1571 novemberében viszont már arról rendelkezett a Kolozsváron tartott országgyűlés, hogy „az váradi káptalannak ő nagysága más pecsétet adjon, mert az mely pecsétek most vagyon, az circulussán az meg holt fejedelemnek neve írattatott, hogy senki kétségben avagy vélekedésben ne essék az káptalan felöl" ${ }^{81} \mathrm{~A}$ váradi hiteleshely eszerint valamikor 1569. április-1571. március 14. (János Zsigmond fejedelem halála) között kaphatott új pecsétet, amely feltehetően a Szapolyai családi címert ábrázolta, és kör-

\footnotetext{
${ }^{79}$ Másik példa szerint egy 1567-ben kelt parancslevélre 1569-ben írnak át okleveleket (DL 72215).

${ }^{80}$ DL 72215 (gyưrűspecsétekkel megerősített oklevél, amely 1569. április 17-én kelt): „Nos Christophorus presbiter, Albertus literatus notarius comitatus Byhoriensis, Gregorius Sandor Waradiensis et Symon literatus Bwdensis, requisitores videlicet literarum et literalium instrumentorum in sacristia sive conservatorio ecclesie Waradiensis repositarum ac aliarum quarumlibet judiciarum deliberationum et legitimorum mandatorum regiorum executores." A corroboratióban nincs utalás az oklevél megpecsételésének módjára, de az országgyűlési végzésben is „önnön pecsétek alatt” kelt kiadványokról esik szó. Vö. ErdKirKv VII/1. 69. sz. Lásd még Papp: A hiteles helyek 111-112.

${ }^{81}$ EOE II. 504.
} 
irata is tartalmazhatta a fejedelem nevét. ${ }^{82} \mathrm{~A}$ későbbiekben minden fejedelemváltáskor új pecsétnyomót vésettek a váradi requisitoroknak, ezek körirata már „Sigillum Capituli Ecclesie Varadiensis”, a pecsétkép azonban továbbra is a fejedelem címere maradt. ${ }^{83}$ További adatok hiányában nehéz eldönteni, hogy mi indokolhatta ezt a nehézkes, az oklevéladó tevékenységben bizonyára zavarokat okozó megoldást, csak feltételezhetjük, hogy a fejedelmi címerkép alkalmazásához hozzájárulhatott Várad kulcsfontosságú szerepe, illetve az, hogy a világi alapon működő hiteleshely nem egy, hanem két egyházi intézmény „jogutódjaként” működött tovább, két hiteleshelyi levéltárat örökölt meg, és talán éppen emiatt egyik régi pecsétjét sem vették át (mint ahogy a gyulafehérvári káptalan és kolozsmonostori konvent esetében történt).

\footnotetext{
${ }^{82}$ A hiteleshely új pecsétjeiről lásd Bunyitay IV. 30., 127. Papp László a káptalan Báthory Zsigmond által adott pecsétjét ismerte, ennek köriratát is közölte. Lásd A hiteles helyek 112. Új pecsét adásáról rendelkezett az 1608 márciusában, Báthory Gábor fejedelemségének kezdetén tartott országgyűlés is, lásd EOE VI. 96. Arra vonatkozóan nincs adatunk, hogy milyen pecséttel erősítették meg az okleveleket, amíg - minden egyes fejedelemváltáskor - az új pecsétnyomó elkészült.

${ }^{83}$ Báthory-címeres pecséttel megerősített oklevelek: DL 74345, 82266; 1627-ben a fejedelmi címert ábrázoló pecsét körirata: Sigil. Authenticum. Capituli. Varadien. (KvNLt, Wesselényi cs lt, 4. doboz).
} 


\section{A KOLOZSMONOSTORI HITELES- HELY A REQUISITORI INTÉZMÉNY MEGSZERVEZÉSÉIG (1557-1575)}

Amint már korábban is utaltunk rá, a reformáció következtében az egykori bencés apátság funkciói közül a XVI. század közepére egyedül a hiteleshelyire maradt továbbra is társadalmi igény. Kolozsvári János apát távozása után (1556), a requisitori intézmény végleges megszervezéséig (1575) a konvent utolsó jegyzője, Óvári János deák személye biztosította valamelyest az oklevéladás folytonosságát. ${ }^{84} \mathrm{~A}$ rendek - a kialakulóban levő államalakulat bizonytalanságai ellenére - biztosítani próbálták a konvent sekrestyéjében őrzött régi levéltári anyag megóvását és zavartalan használatát. 1557 májusában Izabella királyné még a konventhez intézte mandátumát, ${ }^{85}$ de a következő hónapban tartott országgyülés már négynégy tekintélyes nemesre kívánta bízni a gyulafehérvári káptalan és a kolozsmonostori konvent levéltárát, akiknek feladatává tette, hogy a levéltárak őrzése mellett, levélkerestető parancsra hiteles másolatokat állítsanak $\mathrm{ki}^{8}{ }^{86} \mathrm{~A}$ levéltár őreinek kinevezése azonban még évekig váratott magára, mert a kincstár nem volt hajlandó biztosítani requisitorok fizetését, illetőleg vélhetően kielégítette az a mód, ahogyan a hiteleshelyi archívumot Kolozsvár városával kezeltette.

\footnotetext{
${ }^{84}$ Erről az időszakról, illetve János deák személyéről lásd KmJkv I. 88-91., továbbá jelen munka requisitorokra vonatkozó fejezetét.

${ }^{85}$ Kiss Andrei: Locurile de adeverire 62-63.

${ }^{86}$ EOE II. 81.: „Statutum est praeterea ut quatuor prestantes viri nobiles deligantur, qui sub vinculo fidei christianae et honoris Albe in potestate habeant universa privilegia et literalia instrumenta in sacrario sew conservatorio literarum et illa diligenter curent, a quibus paria literarum requisitoriis et preceptoriis literis pro vetere consuetudine excipiantur, ne fideles nostri justis suis juribus quoquomodo priventur. Placuit totidem delegi in Colosmonostor et eodem libere fungi officio."
} 
Ebben az átmeneti időszakban a kolozsvári bíró viselt gondot a konvent levéltárára, melyet ekkor is Kolozsmonostoron, a sekrestyében tartottak. Ha szükség volt a levéltárban őrzött oklevelek közül valamelyikre, a levélkerestető parancsot a városhoz intézték. Izabella királyné 1559. június 22-én kelt parancsát még a kolozsmonostori apátság officiálisához, Nagy Miklóshoz, Bornemisza János kolozsvári bíróhoz, Baráth István esküdthöz és Tályai István városi jegyzőhöz címezte, ${ }^{87}$ a következő évtől kezdve azonban a levélkerestetô mandátumokban már nem találjuk a kolozsmonostori tiszttartó nevét, a leveleket egyszerűen a város vezetőségéhez intézik: „fidelibus nostris prudentis circumspectis judici et juratis civibus civitatis nostre Coloswariensis, requisitoribus videlicet litterarum in sacristia seu conservatorio ecclesie Abbacie de Colosmonostra repositarum per nos ad id delectis". ${ }^{88} 1560$-ban egy mandátumban külön kiemelték, hogy a polgárok a levélkereséshez János deákot, a konvent korábbi jegyzőjét is vigyék magukkal. ${ }^{89}$ Ezután az 1560-1573 közötti időszakban adatolhatóan mindig János deák az, aki kolozsvári polgárok társaságában, a fejedelem levélkerestető parancsára kiment Kolozsmonostorra és megkereste az igényelt iratot. ${ }^{90} \mathrm{Az}$ eljárást végző személyek minden egyes alkalommal visszazárták és lepecsételték a levéltár ajtaját, a kért szöveget vagy a helyszínen rámásolták a mandátum hátára, vagy magukhoz vették az eredetit és bevitték Kolozsvárra, ahol a bíró nevében kiállított és a város nagyobb pecsétjével megerősített átiratban kiadták az oklevelet. ${ }^{91}$

\footnotetext{
${ }^{87}$ DL 37231.

${ }^{88}$ DL 28003, DL 36957 (1563), DF 255030 (1568).

89 ",adhibito vobiscum Joanne litterato alias notario dicti Conventus" (DL 28003).

${ }^{90}$ 1560: DL 28003; 1561: DL 74362; 1563: DL 36957; 1569: DF 253576; 1573: DF 255273.

${ }^{91} \mathrm{KmJkv}$ I. 90. A conservatorium ajtajának visszazárására és megpecsételésére Izabella királyné 1559-ben kelt parancsaiban találtunk utalást: „prescriptumque conservatorium et sacristiam [...] denuo claudere et fideliter obsignare debeatis" (DL 38708, 37231). Az, hogy a levélkeresés és az átirat kiállítása a gyakorlatban hogyan ment végbe, egy 1570-re vonatkozó adat alapján rekonstruálható: „1570 esztendőbe Nÿreo Kálmánnak bíróságában hozta volt Zekel Illyés ő felsége az megh holt fejedelmünk parancsolatját, hogy az lewelet, kiről mostan contencio vagyon az conventből alá hozatnák és az thanács házban lenne bizonyos ideiglen, ők azkor meg hatták volt Orgonas Benedeknek, ki requisitor volt az notarius mellet, hogy alá hozná, ki alá is hozta és leh tőtteh elöttek az thanács házban, mely lewél az thanács házban volt" (MOL R 314, Városi iratgyüjtemény, 10. doboz, Vegyes iratok, 2a csomag, f. 25 $5^{\mathrm{r}-\mathrm{v}}$ ). Ezek szerint a konvent levéltárából lehozott eredeti oklevelet a másolat kiállításáig a tanácsházban őrizték. Az említett Orgonás Benedek kolozsvári esküdt és ispotálymester volt (lásd Kiss András: Oklevéltár Kolozsvár történetéhez 1592-ig. Kézirat. 538. sz.), ebben az esetben ő kísérte el Kolozsmonostorra János nótáriust.
} 
Ennek az időrabló, eléggé nehézkes és bizonytalan eljárásnak szerettek volna a rendek véget vetni állandó és felelősségre vonható levéltáros(ok) kinevezésével..$^{92}$ János Zsigmond erre válaszul elrendelte, hogy a konvent levéltárát szállítsák át Gyulafehérvárra és ott bízzák a káptalani requisitorok őrizetére, akiknek létszámát hajlandó lett volna egy személlyel meg is növelni. ${ }^{93} \mathrm{~A}$ költöztetésre azonban szerencsére - tekintettel a gyulafehérvári káptalani levéltár későbbi pusztulására - nem került sor. 1563 júniusában az országgyűlés a tényleges helyzetet törvényesítette, amikor János deák vármegyei jegyzőt requisitornak nevezte ki. ${ }^{94} \mathrm{Az}$ intézkedés szerint a levélkereséskor Ovári János deák mellett továbbra is mindig jelen kellett, hogy legyen egy kolozsvári esküdtpolgár, a gyakorlatban azonban általában két polgár kísérte el a jegyzőt Kolozsmonostorra..$^{95}$ János deák javadalmazását az átiratot igénylő fél által az átírásért fizetendő illetékekkel kívánták megoldani. Ennek értelmében a keresésért 50 dénárt, az átírás első lapjáért ismét 50 dénárt, minden további lapért 10 dénárt kérhetett a felektől.

${ }^{92} \mathrm{Az} 1560$ márciusában tartott országgyưlés is sürgeti requisitorok kinevezését: „Statutum est, ut Maiestas sua deligat homines idoneos ad conservacionem literarum et literalium instrumentorum in conservatorio Colosmonostra repositarum, ne exinde regnicolis utriusque regni Maiestatis sue damnum subsequi possit". EOE II. 176.

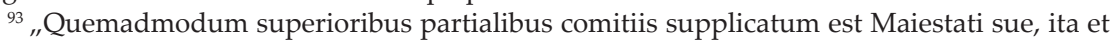
modo supplicatur dignetur Maiestas sua conservatorem literarum et literalium instrumentorum regnorum Hungarie et Transsylvanie in conservatorio Monasterii Colosiensis repositarum, de medio nobilium tres idoneas personas, qui et dei et dignitatis Maiestatis sue suique ipsius et honoris rationem habeant, eligere et conservationem illarum illis committere. Visum est sacre Maiestati Regie et consilio, ut litere et instrumenta literalia deducantur Albam et requisitionis earum habeant curam illi, qui reliquarum nunc habent; unus tamen nobilis deligatur ut sint quattuor". EOE II. 195.

94 "Ittem quod Joannes Literatus notarius conventus Monasterii et comitatus Colosiensis die sedis iudiciarie primitus celebrande, in facie eiusdem sedis coram egregiis Joanne de Sombor, Gregorio de Fratha et Andrea Tholdalagii, presente eciam judice civitatis Coloswariensis super fideli requisitione, emanatione et conservatione literarum dominorum regnicolarum juramentum praestare debeat. In requisitionibus autem semper unus juratorum civium eiusdem civitatis Coloswar illi adhibeatur, qui pro requisitione literarum habebit denarios quinquaginta. Reinventis autem et prescriptis sigillatisque literis, unum folium papiri continentibus rursus denarios quinquaginta, ultra vero unum folium pro singulo folio denarios decem habere valeat et non amplius". Uo. 218-219. Az a kérdés, hogy János deák a fejedelmi tábla vagy pedig Kolozs vármegye széke előtt tette le esküjét, nehezen dönthető el. Sombori Jánosról nem tudtuk megállapítani, hogy milyen szerepe volt ebben az időszakban, de Frátairól és Tholdalagiról tudjuk, hogy a fejedelmi ítélőszék ülnökei voltak (lásd Trócsányi: Központi kormányzat 359-360.), Frátai viszont 1572-ben Kolozs vármegye ispánjaként végrendelkezett. Lásd Horn Ildikó: Hit és hatalom. Az erdélyi unitárius nemesség 16. századi története. Bp., 2009. 215. (7. jegyzet). Mégis valószínübbnek túnik, hogy mivel nem csak a Kolozs megyeiek fordulhattak ügyeikkel a konventhez, az eskütétel a fejedelem ítélőszéke előtt történt meg, így a kinevezett requisitor lényegében a kisebb kancelláriának tartozott elszámolással, mely szerv egyébként is a peres eljárások során igényelte az átiratok kiállítását (a levélkerestető parancsok nagy részét az ítélőmesterek intézték a hiteleshelyekhez).

${ }^{95}$ DL 36957, DF 253576. 
A nemesség azonban ezzel a megoldással sem lehetett elégedett. 1565 júniusában a rendek kérték a fejedelmet, „,hogy az kolozsmonostori leveleket, privilegiumokat és az nemesség igazságára való registrumokat ő felsége vitesse Fejérvárra, hogy a káptalanbeli levelekkel együtt legyenek; választassanak gondviselők; méltó, hív és jámbor személyek gondviselése alá adassanak, kik az előtt tisztek szerént erre gondot viseltenek, kiknek ő felsége kegyelmesen fizetést is tégyen" ${ }^{96} \mathrm{Az}$ országgyülés vélhetően nem tartotta biztosítottnak a levéltár megfelelő őrzését a kincstári birtokká vált egykori apátsági épületben, és talán az is zavarta, hogy a jogbiztosító iratokat nem nemesek, hanem Kolozsvár városa kezelte. A költöztetés azonban újból elmaradt, az átiratokat továbbra is János deák írta, és a város pecsétje alatt állították ki. Ez a terv végül lekerült a napirendről, 1568 nyarán a rendek már újra azt kérték a fejedelemtől, hogy Kolozsmonostorra is nevezzen ki requisitorokat. ${ }^{97} \mathrm{~A}$ levéltárőrök kinevezését azonban a fejedelem tovább halogatta. 1570 májusában újból megfelelő személyzet állítását kérte az országgyưlés, sőt a rendek újabb igényekkel álltak elö, javasolva, hogy a "míltó requisitorok" a levéltárra való gondviselés mellett „,az régi szokott helyeken executioba eljárhassanak igazán, az nemesség levelének penig pariáját, ha kik deponálni akarják, híven bevegyék, és mikor az nemességnek szükség lészen, az pariáját requisitoriájával az régi jó végezések szerint kivihessék" ${ }^{98}$ Kétségtelen tehát, hogy egyre sürgetőbb a nemesség azon igénye, hogy a régi, megszokott gyakorlatot élesszék újra, állítsák helyre a kolozsmonostori hiteleshelyet, és bízzák meg a requisitorokat a külső hiteleshelyi tevékenység (iktatások, tanúvallatások stb.) végzésével, valamint ne csak saját levéltárukból állítsanak ki átiratokat, hanem a nemesek okleveleiről készült másolatokat is őrizzék meg, és a felek kérésre állítsanak ki azokról hiteles oklevelet. A levélkeresők javadalmazását a rendek bizonyos dézsmák átengedésével kívánták megoldani, a fejedelmet pedig arra kérték, hogy a kolozsvári bíró számára külön hiteleshelyi pecsétnyomót készíttessen. ${ }^{99} \mathrm{Az}$ ügy megoldása érdekében a következő év novemberében a személyi javaslatokat is megtették, kérve immár az új fejedelmet, Báthory Istvánt, hogy Tolnai Miklós deákot, Csanádi János deákot és a kolozsvári jegyző, Zalánkeményi Miklós deákot nevezze ki a

\footnotetext{
${ }^{96}$ EOE II. 289.

${ }^{97}$ EOE II. 340.: „,Felségednél nyilván vagyon, hogy az kolosmonostori conventus ez felséged országának levelei tartásának tárháza, könyörgünk azért felségednek, legyen felségednek kegyelmes gondviselése az levelek tartására és őrizésére, választana oly személyöket erre, kik híven viselnének gondot róla."

${ }^{98}$ EOE II. 372-373.

${ }^{99}$ Uo.: „az kolosvári bírónak az levelek pecsétlésére való pecsétet adjon, az ő kegyelmes ígíreti szerint."
} 
kolozsmonostori hiteleshelyhez. ${ }^{100} \mathrm{Az}$ új személyzet kijelöléséhez bizonyára az is hozzájárulhatott, hogy e tájban János deák éppen oklevél-hamisítás gyanújába keveredett, és emiatt egy időre börtönbe is került. Az ügyről egy 1572-ben kelt tanúvallatásból értesülhetünk. Ekkor azt próbálták kideríteni, hogy Kolozsmonostorról a városba bevitt oklevélbe miképpen került "glossalas vagy közte való más kéz irás" ${ }^{101} \mathrm{Az}$ a bonyolult eljárás, ahogyan az átiratok kiállítására sor került, sok visszaélésre adott lehetőséget, főként ha az eredeti okleveleket nem a konvent sekrestyéjében írták át, hanem a városba vitték, ahol egy ideig a tanácsházban tartották. Habár János deák esete is a konvent működésének rendezése mellett szólt, vélhetően a bizonytalan politikai helyzet miatt a rendek által javasolt személyek beiktatása elmaradt.

Az országgyűlésen 1573 májusában ismét szóba került a kolozsmonostori konvent ügye. A rendek felrótták, hogy a levéltár eddig pusztán állott, és a levelek is rendtartás nélkül voltak. Ezért újból kérték a fejedelmet, hogy válasszon „,három méltó személyt... oda az conventben, az leveleknek conservatiójára és requisitiójára, és azoknak annyi authoritást és pecsétet adjon minden executiókra, mint az váradi requisitoroknak, kiknek fizetéseket is nagyságodra támasztottuk" ${ }^{102}$ Újra és egyre sürgetőbben jelentkezett tehát az igény, hogy a konventi hiteleshely executiókat is végezhessen, követendő mintának pedig a váradi káptalant tartották, ahol néhány éve már működtek requisitorok. 1573. május 29-én azonban a konventnek még nem volt saját pecsétje, és a levélkeresést is ugyanaz a János deák végezte, aki a szekularizáció előtt az apátság nótáriusa volt. ${ }^{103}$

${ }^{100}$ EOE II. 506: „Ezt is hátra nem hagytuk, hanem egy akaratból végeztetett, hogy az monostori conventben az levelek keresésére, őrzésére és kiadására országúl választottuk Tolnai Miklós deákot, avagy Csanádi János deákot, és Miklós deákot az kolosvári notariust, hogy az leveleket jól tractálják Monostoron azon elébbeli conservatoriumban, és az kinek ki kell adni, ki adják, minden csalárdságot eltávoztatván. Az ur ő nagysága megesküdtesse őket és fizessen nekik az ő kegyelmes igérete szerént."

${ }^{101}$ A vallatás során ,"tőn kérdést arról is Fejerwarj Ambrus, hogy János deák az Convent notariusa ez előt való fogsága felől és hogy suspectus volt. Megvallanák mit felőle tudnak, kik azt vallák, hogy halloták azt hogy fogva volt Tordán valami levél dolgáért, de mi vétke volt benne, nem tugyák" (MOL R 314, Városi iratgyüjtemény, 10. doboz, Vegyes iratok, 2a csomag, f. $\left.25^{r-v}\right)$.

102 EOE II. 541.

${ }^{103}$ DF 255273: Báthory István fejedelem levélkerestető parancsát ,,judicii et juratis civibus civitatis Coloswariensis, requisitoribus videlicet litterarum et litteralium instrumentorum in sacristia seu conservatorio castelli de Colosmonostra repositarum” intézi, mire „dominus judex noster una cum discreto viro Joanne litterato jurato notario Abbacie de Colosmonostra, prudentis et circumspectos Joannem Kalmar ac alterum Joannem Thymar juratos cives fratres nostros ad perquirendo prefatas litteras transmisisset". Egyedül ebben az oklevélben találkoztunk a kolozsmonostori kastély sekrestyéjének említésével, ami valószínúleg arra utalhat, hogy az 1569-ben Forgách Ferencnek adományozott apátsági épületeket (lásd ErdKirKv VII/1. 79. sz.) a kancellár ekkorra már átalakította. A konventi levéltárat viszont még mindig a régi helyén, az egykori apátsági templom sekrestyéjében őrizték. 



\section{A HITELESHELYEK SZEREPÉT ÁTVEVŐ INTÉZMÉNYEK A HITELESHELYI OKLEVÉLKIADÁS ÚJRAINDULÁSÁIG}

A kolozsmonostori konvent és az erdélyi káptalan hatókörébe tartozó terület lakosainak a hiteleshelyi tevékenység szünetelése/leszűkülése idején is szüksége volt, leginkább perei során, olyan iratképző szervekre, amelyek az ügyleteket írásban is rögzíteni tudták, és ezekről okleveleket állíthattak ki. Istványi Géza állítása szerint az 1557. évi országgyűlés a bírói parancsra végzett hiteleshelyi eljárásokat - „a káptalanok és a konventek működésének megszüntetése után" - Erdélyben királyi emberekre bízta. ${ }^{104}$ Papp László némileg árnyalta ezt a megállapítást, úgy vélve, hogy az idézett rendelkezés csak azokra a helyekre vonatkozott, ahol konvent nem működött. ${ }^{105} \mathrm{Az}$ országgyülési végzés szövegének valamivel alaposabb vizsgálata azonban arra a következtetésre vezetett, hogy a határozat a magyarországi (partiumi) nemességről szólt, akik a régi szokás szerint, ha hiteleshely nem volt a közelben, két nemesemberrel is végeztethettek eljárásokat. ${ }^{106}$ Tekintetbe véve az akkori zavaros állapotokat, illetőleg a hiteleshelyek pusztulását, ${ }^{107}$ érthetőnek tünik, hogy a nemesség mellőzni

\footnotetext{
${ }^{104}$ Istványi: A magyarnyelvű írásbeliség 69.

${ }^{105}$ Papp László: A hiteles helyek 116. és 2. sz. jegyzet.

${ }^{106}$ EOE II. 74.: „In processu iuris domini Hungari nunc quoque juxta antiquam eorum consuetudinem quam in eiusmodi processibus Posonii observarunt procedere debebunt ita quod ubi conventus est, cum illo, ubi vero non est cum duobus nobilibus hominibus regiis procedere debebunt, quorum tamen fides aeque acceptatur atquam conventus." A domini Hungari ebben az időszakban a partiumi, Erdélyen kívüli nemességet jelölte. Az 1559 júniusában tartott gyulafehérvári országgyűlésen a rendelkezést vélhetően már az erdélyi nemesekre is kiterjesztették, lásd EOE II. 116.

${ }^{107}$ Erről bővebben lásd Papp László: A hiteles helyek 6-17.
} 
kényszerült a konventi és káptalani tanúbizonyságokat, és esetenként kijelölt királyi emberek útján hajtatta végre a mandátumokat. ${ }^{108}$

\section{1. A királyi és vajdai/fejedelmi emberek hiteleshelyi jellegü tevékenysége Erdélyben}

Erdélyben már a szekularizáció elött is szokás volt, hogy hatósági parancsra vajdai vagy királyi emberek végezték a tanúvallatásokat, idézéseket, határjárásokat, és valamivel ritkábban a birtokba való bevezetéseket és iktatásokat is. ${ }^{109} \mathrm{Az}$ executiókat végző személyek tekintélyesebb helybéli nemesek, illetve utóbb egyre gyakrabban a fejedelmi kancellária íródeákjai voltak. Okleveleik nyelve eleinte latin, majd, mivel az oklevelek megfogalmazására egyre kevesebben voltak képesek, a magyar nyelvű relatiók száma nő, 1544-től kezdve már szinte évente előbukkan egy-egy anyanyelvü jelentés. ${ }^{110}$

A szekularizáció előtt a kolozsmonostori konvent által lefedett területen, nevezetesen Kolozs vármegyében már 1559-ből találtunk példát arra, hogy a birtokba való bevezetést és iktatást az illető vármegyében birtokos nemesek végezték. ${ }^{111} 1560$-ban két vármegyei nemes mellett az iktatás végrehajtói között a nagyobb kancellária egyik jegyzője, illetőleg Doboka vármegye alispánja tünik fel olyan birtokokba való bevezetéskor, melyekről korábban biztosan a konvent állította volna ki a jelentést. ${ }^{12}$ János Zsigmond választott király 1560. március 8-án hét Doboka vármegyei nemeshez címezte iktatóparancsát, melyben saját adománylevele alapján arra utasította őket, hogy a Kenden levő vár officiálisát, Csakor Ferencet vezessék be az ugyanazon vármegyében található sófalvai birtokrészbe és azt számára iktassák. ${ }^{113} \mathrm{Az}$ iktatás végrehajtóinak, Cserényi Gergelynek és Inácsi Mi-

${ }^{108}$ Ezen a vidéken már 1550-ben gondok voltak a hiteleshelyekkel, sokatmondó az, hogy Ferdinánd egy időben szabályozta az egri káptalan, a leleszi és jászói konvent, az elpusztult hiteleshelyek pecsétjeinek begyűjtése, illetve a vármegyei pecsétek ügyét (talán ez arra vall, hogy a korábban hiteleshelyek által végzett executiók egy részét ezentúl a vármegyei tisztikar hajtotta végre, ehhez volt szükség intézményi, közhitelü vármegyei pecsétnyomó vésésére). A végzések szövegét lásd Magyar Törvénytár. 1526-1608. évi törvényczikkek. Fordították és utalásokkal ellátták Dr. Kolosvári Sándor és Dr. Óvári Kelemen. Bp., 1899. 290-291.; 1552-ben arról is döntöttek, hogy az elnéptelenedett hiteleshelyek a bírói parancsokat nem hajthatják végre: „Statutum est praeterea ut in conventibus, vel capitulis, ubicunque ad minus quinque personae ecclesiasticae non fuerint: ad executiones exire, et ea, aliave, quae officiorum eorum sunt, in negotiis publicis regni administrandis gerere non possint" (Uo. 328).

${ }^{109}$ Erről bővebben lásd Istványi: A magyarnyelvü írásbeliség 69-71.; Pécsi: Fejedelmi kancellária 44-45.; Papp László: A birtokba-iktatás 373. (2. jegyzet).

${ }^{110}$ Istványi: A magyarnyelvü írásbeliség 69.

${ }^{111}$ ErdKirKv VII/1. 22. sz.

${ }^{112}$ Uo. 23. sz.

${ }^{113}$ Uo. 25. sz. 
hálynak zárt alakban kelt, saját pecsétjükkel és aláirásukkal megerősített jelentéséből kiderül, hogy a királyi emberek is lényegében a korábbi minta alapján jártak el: az iktatás helyszínére összehívták a szomszédokat, akiknek a neveit is feljegyezték, illetve három teljes napig a helyszínen időztek, ahogyan erre az oklevél szövegében is utaltak. ${ }^{114}$ A jelentés kiállításával a királyi emberek nem várták meg a dies fatales, a statutio után számított 15 nap leteltét, hanem azt már harmadnap elküldték a végrehajtást elrendelő választott királynak. Ezek után már csak az udvarban lehetett tiltást tenni, bizonyára az iktatást és bevezetést követő 15 napon belül, de erre nem került sor, így János Zsigmond függőpecsétes oklevelében átírva erősítette meg az iktatást. ${ }^{115} \mathrm{Az}$ udvar vagy pontosabban a kialakuló fejedelmi kancellária ezzel is a hiteleshely szerepét vette át, minthogy korábban a statutiót végző vagy bármely hiteleshely előtt lehetett tiltakozni. ${ }^{116} \mathrm{Az}$ iktatáskor kinyilvánított tiltakozás esetleges visszavonása is a kancellárián történt, 1569 májusának első napján például János Zsigmond lengyel familiárisa Csáky Mihály kancellár előtt vonta vissza azon tiltását, melyet éppen egyik gyulafehérvári káptalani levélkereső, Szentmihályi Lőrinc részére való statutio alkalmával tett. ${ }^{117}$

Hogy számszerűen is valamelyest képet alkothassunk a királyi emberek által végzett külső hiteleshelyi tevékenységről, János Zsigmond 1569-1570. évi töredékes királyi könyvét vettük vizsgálat alá. ${ }^{118} \mathrm{~A}$ választott király a nevezett időszakban összesen 21 iktatáshoz adta jóváhagyását, átírva és megerősítve az ezekről kelt jelentéseket. Az összes relatióból 19 alkalommal, tehát az esetek 90\%-ában királyi emberek állították ki az okleveleket, és csupán két alkalommal, 1568-ban és az ezt követő évben találtunk hiteleshely által végrehajtott iktatást, mindkét esetben természetesen a váradi requisitorok voltak a kibocsátók. Egyértelmű tehát, hogy az egykori erdélyi vajdaság területén az iktatásokat ebben az időszakban nem hiteleshelyek végezték. A váradi levélkeresők által kiállított oklevelek

\footnotetext{
${ }^{114}$ MOL F 15. VI. (János Zsigmond királyi könyve) $53^{\mathrm{v}}$ : „tribus diebus legittimis iuxta Regni consuetudinem inibi moram continuam fecimus".

${ }^{115}$ ErdKirKv VII/1. 28. sz. A későbbiekben az iktatást végző királyi/vajdai emberek, akárcsak korábban a hiteleshelyek, a 15. nap letelte után állíthatták ki oklevelüket, ahogyan a parancslevelek is utasították őket. A Báthory Zsigmond kancelláriáján használt formuláskönyvben található bejegyzésben például jelentésük kijavítására utasították az iktatást elvégző vajdai embereket, mivel „data earundem litterarum vestrarum non ad decimum quintum, prout praescriptae litterae domini fratris nostri observandissimi sonassent, verum ad tertium diem a die executionis vestrae computando conscripta et emanata fuissent". Lásd MOL F15. XII. p. 14-15.

${ }^{116}$ Papp László: A birtokba-iktatás 378.; 1569. november 14-én Valkai Miklós tett tiltást a kancellárián, amiért őt és az általa képviselteket Csáky Mihály határidőre megidézte, lásd ErdKirKv VII/1. 186. sz. Vö. 236-237. sz. (a kancellár elött tett tiltakozások).

${ }^{117}$ ErdKirKv VII/1. 97. sz.

${ }^{118}$ ErdKirKv VII/1.
} 
csekély száma pedig arra utalhat, hogy a Partium területén is megoszlott ez a tevékenység az 1566 után felállított káptalani requisitorok és a királyi emberek között.

Az alábbi táblázatból az is kiderül, hogy milyen arányban szerepeltek az iktatóparancsok végrehajtói között az illetékes (az adott vármegyében birtokkal rendelkező) vármegyei nemesek, illetve a kancelláriai íródeákok, valamint, hogy legtöbbször hányan végezték el a statutiót. A királyi emberek által végrehajtott 19 iktatás közül összesen 15 alkalommal járt el két személy, tehát egyre inkább szabályszerünek számított az, hogy ketten hajtották végre a megbízást (a későbbiekben csak kivételesen találunk ennél több jelentést tevőt).

\begin{tabular}{|c|l|c|}
\hline $\begin{array}{c}\text { Hányan } \\
\text { jelentettek? }\end{array}$ & \multicolumn{1}{|c|}{ Kik végezték az iktatást? } & $\begin{array}{c}\text { Hány } \\
\text { alkalommal? }\end{array}$ \\
\hline 4 & vármegyei jegyző, alispán, két nemes & 1 \\
\hline 3 & vármegyei nemesek & 1 \\
\hline 3 & $\begin{array}{l}\text { vármegye alispánja, jegyzője, egy aranybe- } \\
\text { váltó }\end{array}$ & 1 \\
\hline 3 & a nagyobb kancellária íródeákjai & 1 \\
\hline 2 & kancelláriai íródeák és vármegye alispánja & 1 \\
\hline 2 & kancelláriai íródeák és vármegyei nemes & 4 \\
\hline 2 & vármegyei nemesek & 10 \\
\hline
\end{tabular}

Az iktatások több mint felénél az illetékes vármegyében birtokkal rendelkező nemesek jártak el, de viszonylag gyakran fordult elő az is, hogy a kancellária íródeákjai közül bíztak meg valakit. Mellettük számos esetben valamilyen vármegyei tisztség viselője szerepelt végrehajtóként. A fentiek, illetve korábbi, középkori előzmények jelzik azt, hogy a vármegyék által folytatott hiteleshelyi tevékenységet külön kell kezelni. Erre az alábbiakban még sort kerítünk.

A vármegyei nemesekkel, kancelláriai íródeákokkal való „exequáltatás" a gyulafehérvári és kolozsmonostori hiteleshelyek újjászervezése (1575) után sem szünt meg, amint ez az országgyülési végzésekben is többször kifejezésre került. ${ }^{119}$ Arra a kérdésre, hogy milyen arányban oszlott meg ez a munkaterület a requisitorok és a királyi/fejedelmi emberek között, a következőkben még kitérünk.

A homo regiusok alkalmanként bevallásokat is írásba foglaltak. Későbbi adatokból tudjuk azt, hogy bírói (ítélőmesteri) parancsra a kijelölt királyi/vajdai emberek ügyvédvallásokat vehettek fel, vagy éppen meg-

\footnotetext{
${ }^{119}$ Papp László: A hiteles helyek 116.
} 
állapíthatták az ügyfelük életkorát, de bizonyosak lehetünk afelől, hogy kiküldetéseik során más jellegü fassiókat is írásba foglalhattak. ${ }^{120}$

\section{2. A vármegyék hiteleshelyi jellegú tevékenysége}

A vármegyék bírói parancsra már a középkor folyamán végeztek olyan jellegü tevékenységet, amely egyébként a hiteleshelyek feladatkörébe tartozott. ${ }^{121}$ A külső hiteleshelyi munkák közül általában tanúvallatások elvégzésével bízták meg a megyéket, határjárással, iktatással ritkábban. ${ }^{122}$

A középkori megyék oklevéladó működésének másik részét a különböző ügyletek írásba foglalása - bevallások felvétele - jelentette. ${ }^{123}$ Ez nem csak azokon a területeken számított elterjedt gyakorlatnak, ahol nem volt a közelben hiteleshely, hanem például Kolozs vármegye is gyakran állított ki oklevelet az előtte megkötött szerződésekről, tiltakozásokról akkor is, ha a közgyűléseket a Kolozsmonostorhoz közeli Bácsban vagy alkalmanként éppen Kolozsváron tartották. ${ }^{124}$

A vármegyék hiteleshelyi jellegü tevékenysége a szekularizáció után is folytatódott. Az 1576. évi medgyesi országgyűlés Bihar vármegye esetében „,a töröknek félelme miatt” engedélyezte, „hogy mindenütt az vármegyében egy viceispány és egy szolgabiro az notáriussal egyetemben szabadon exequálhasson". ${ }^{125}$ Néhány évvel korábbi adatok alapján megbizonyosodhattunk arról, hogy a Partium területén a vármegyék már korábban végeztek iktatást. ${ }^{26} \mathrm{Az}$ ítélőmester által a megyékhez küldött mandátumokból arra is következtethetünk, hogy milyen feladatok elvégzésével bízták meg

${ }^{120}$ Lásd Istványi: A magyarnyelvú írásbeliség 71.; MOL F15. XII. (kancelláriai formuláskönyv). 70 .

${ }^{121}$ Erről bővebben lásd C. Tóth Norbert: Szabolcs megye 93-98.; Tringli István: Megyék a középkori Magyarországon. In: Honoris causa. Tanulmányok Engel Pál tiszteletére (szerk. Neumann Tibor és Rácz György). Bp.-Piliscsaba, 2009. 502-504.

${ }^{122}$ XV. századi példák Kolozs megye által végzett tanúvallatásokról: DF 255278, 255299, 257828.

${ }^{123}$ C. Tóth Norbert: Szabolcs megye 99.

${ }^{124}$ 1513. július 20-án Kolozs megye ispánjai és szolgabírái előtt Veres János, valamint bikali Vitéz Tamás és András tiltotta el Bánffy Jánost Alsófüld birtok határának elfoglalásától (DF 253763); 1530. április 26-án Doboka vármegye állít ki oklevelet egy összeg átvételéről (nyugta), lásd A Wass család cegei levéltára. Valentiny Antal oklevélkivonatait felhasználva bevezető tanulmányokkal és jegyzetekkel közzéteszi W. Kovács András. Kolozsvár, 2006. 649. sz. További példák lásd Kiss Andrei: Locurile de adeverire 65. A megye ítélőszéke előtti ügyletekről jegyzőkönyvet is vezettek, Torda sedria regisztrumait már a XV. század végén említik, lásd W. Kovács András: Administrația comitatului Hunedoara în Evul Mediu. In: Sargetia. Acta Musei Devensis. XXXV-XXXVI (2007-2008). 220.

${ }^{125}$ EOE II. 577.

${ }^{126}$ 1569. június 30-án Közép-Szolnok vármegye alispánja és szolgabírája jelentenek iktatásról; 1571. március 25-én Máramaros vármegye szolgabírái állítanak ki jelentést egy iktatásról, lásd ErdKirKv VII/3. 69. sz. 
a vármegyei hivatalok viselöit. A tanulmányozott formuláskönyv alapján úgy tűnik, hogy a leggyakrabban idézéseket hajtottak végre, ${ }^{127}$ de időnként a birtokosztály foganatosítását is a vármegyére bízták. ${ }^{128} \mathrm{~A}$ közgyülések alkalmával esetenként arra is sort kerítettek, hogy az előttük végbement ügyletekről állítsanak ki bizonyságlevelet. ${ }^{129}$

\section{3. A fogott bírák (közbírák) oklevéladó tevékenysége}

Az érdekeltek nem folyamodhattak kisebb ügyes-bajos dolgaikkal minden esetben a sokszor távoli - vagy éppen nem működő - hiteleshelyekhez azért, hogy a megállapodásaikat írásba foglaltassák, hanem kezük ügyében levő szavahihető íástudó személyeket kértek fel bizonyságlevelek kiállítására. Az ilyen személyek a városi és falusi értelmiség vagy a birtokos nemesség írástudó tagjai közül kerültek ki. Az oklevél súlyának emelése érdekében az irat megszerkesztésére a felek igyekeztek minél tekintélyesebb, többnyire hivatalviselő személyeket hívni, vagy egykori kifejezéssel „fogni". ${ }^{130}$ Abban az esetben, ha a fogott bírák egyúttal vármegyei tisztségeket is viseltek - vármegyei pecsétek hiányában - nehéz eldönteni, hogy az adott oklevél fogott bírói vagy pedig vármegyei kiadványnak minősíthető.

Bevallásokat leggyakrabban a hiteleshelyektől egyébként is távol levő Székelyföldön foglaltak írásba fogott bírák, de Erdély többi részén is szokásban volt a bizonyságlevelek közbírákkal való kiállíttatása már a szekularizációt megelőző évtizedekben is. 1552-ben például Torda vármegyei jószág cseréjéről, illetőleg zálogosításáról állítanak ki fogott bírói oklevelet, magyar nyelven. ${ }^{131} \mathrm{Az}$ erdélyi hiteleshelyek újjászervezése (1575) előtti időszakban, 1568-ban kelt Ördög János és Sombori László fogott bírák le-

${ }^{127}$ MOL F15. XII. 29-32., 42-43.

${ }^{128}$ Uo. 45-47. Ez esetben azonban a birtokok felosztása a törvények szerint is a vármegye hatáskörébe tartozott: „,cum autem huiusmodi divisio bonorum inter fratres et sorores carnales, patrueles item et matrueles, nec non parentes et liberos, juxta contenta decreti non longo litis processu, sed medio dumtaxat comitum, vice comitum et judicialium comitatus illius ubi huiusmodi bona dividenda adiacere dinoscentur legitime fieri atque peragi possit."

${ }^{129}$ 1602. január 29-én Körösbányán, „loco scilicet sedis nostrae iudiciariae” keltezik oklevelüket Zaránd vármegye hivatalviselői, melyben egy inscriptiót hitelesítenek, lásd ErdKirKv VII/3. 1778. sz.; 1590-ben Hunyad vármegye várnagyai és alispánjai állítanak ki oklevelet birtok eladásáról, vö. ErdKápJkv VIII/1. 678. sz. Korábbi példa, 1574-ből két krasznai alispán oklevele egyezségről, lásd Szabó T. Attila: A Wesselényi-levéltár és XVI. századi magyar iratai. In: Levéltári Közlemények 16/1938. 213.

${ }^{130}$ A kifejezés jelentéséről lásd Szabó T. Attila: Hivatal; hivatalos. In: A szó és az ember. Válogatott tanulmányok, cikkek II. Bukarest, 1971. 127-128.; A közbírák magyar nyelvű oklevélkiadásáról lásd Istványi: A magyarnyelvú írásbeliség 71-73.

${ }^{131}$ Szabó T. Attila: Egy 1552-i mezóségi szövegemlék és nyelvjárástörténeti adalékai. In: A szó és az ember. Válogatott tanulmányok, cikkek II. Bukarest, 1971. 495-496. 
vele, melyben kikötötték, hogy az egyezségről alkalomadtán „,mester előtt vagy káptalanban viszontag való vallást tesznek" ${ }^{132} \mathrm{Ez}$ a kitétel, hogy az egyezségről „hitelesebb” oklevélkiadó, tehát az egyik ítélőmester vagy valamelyik hiteleshely is iratot adjon, gyakran szerepel a fogott bírák előtt kötött szerződések szövegében (még a fassiók bevételének szünetelése idején is!), ami arra utal, hogy a kortársak szemében az ilyen jellegü okleveleknek nem lehetett akkora bizonyító ereje, mint egy hiteles pecséttel bíró testület által vagy a fejedelem nevében az ítélőmester által kiadott iratnak. A hiteleshelyek esetében az is előnynek számíthatott, hogy a káptalanok és a konventek rendelkeztek levéltárral, amelyben a kiállított oklevél parpéldányát (vagy jegyzőkönyvi másolatát) megőrizték.

\section{4. A fejedelmi kancellária hiteleshelyi jellegü tevékenysége}

Janits Iván az erdélyi vajdák középkori oklevéladó tevékenységét elemző alapos munkájában néhány szóval arról is megemlékezett, hogy egyes kiadványokon - többnyire azokon, melyek tárgya valamilyen bevallás (egyezség, adásvétel stb.) - a szöveg alatt a jobb oldalon a coram szó és egy név vagy egy név rövidítése olvasható. ${ }^{133}$ Ez szerinte arra utalhat, hogy a bevallás a vajda előtt, az „illető kancelláriai tisztviselő jelenlétében történt, de azt is jelentheti, hogy a bevallást az illető maga vette fel, s igazolásképpen írta rá a nevét". Mindebből arra a következtetésre jutott, hogy a vajdai kancelláriának önálló hiteleshelyi tevékenysége kezdett kialakulni.

Pécsi Anna röviden említést tett arról, hogy a vajdai kancellária fassionális okleveleket is adott ki, de szerinte a hiteleshelyi jellegű oklevelezés kezdeteit és lényegét csak a "középkori vajdai gyakorlat teljes ismerete alapján" lehetne felvázolni. ${ }^{134}$ Tény az, hogy a vajdai kancelláriának már a XVI. század elejétől kezdve nyomon követhető a hiteleshelyi jellegű tevékenysége, a Mohács előtti évtizedekben számos alkalommal állítottak ki vajdai pecsét alatt fassionális okleveleket. ${ }^{135}$ Bizonyára nem tévedünk, ha a vajdai kancellária „,hiteleshelyi” oklevéladásának kezdeteit a külön erdélyi protonotariusság kialakulásához kötjük, és a XV. században már hasonló

\footnotetext{
${ }^{132}$ KvNLt, Bánffy lt nr. 25/35 (régi jelzet: fasc. Ila).

${ }^{133}$ Janits Iván: Az erdélyi vajdák igazságszolgáltató és oklevéladó múködése 1526-ig. Bp., 1940. 73.

${ }^{134}$ Pécsi: Fejedelmi kancellária 13.

${ }^{135}$ Kiss Andrei: Locurile de adeverire 65. További példák 1513 (zálogosítás): DL 65461; 1514 (csere): DL 30265; 1514 (nyugta): DL 62998; 1515 (ügyvédvallás): DL 63004; 1516 (birtok átengedése): DL 22744; 1525 (birtok eladása): DL 63044; 1526 (birtok eladása): DL 63048.
} 
tevékenységet folytató kúriai ítélőmesterek oklevéladó tevékenységével hozzuk párhuzamba. ${ }^{136}$

Minden jel szerint a kialakuló fejedelmi kancelláriában az ítélőmesterek - a Mohács előtti gyakorlatot folytatva - továbbra is állítottak ki fassionális okleveleket az előttük megkötött ügyletekről. Erre azért is szükség lehetett, mivel a szekularizált hiteleshelyek egy ideig nem végeztek ilyen jellegü tevékenységet. 1575-ig, majd azután is gyakran találunk olyan fogott bírói okleveleket, melyekben kikötik, hogy az előttük tett bevallásról valamelyik hiteleshely vagy ítélőmester előtt is iratot állítanak ki. ${ }^{137}$ Pécsi Anna szerint a fejedelmi kisebb kancellária hiteleshelyi tevékenysége az igazságszolgáltatással kapcsolatos fassionális oklevelek kiadására szorítkozott, és kisebb teljesítményű volt, mint a nagyobb kancellária hasonló gyakorlata. ${ }^{138} \mathrm{Ez}$ a megállapítás azonban nem állja meg a helyét, sőt a helyzet valószínúleg éppen fordított volt: az ítélőmesterek végeztek sokkal nagyobb arányban hiteleshelyi jellegü tevékenységet, a középkori mintákat és hagyományokat követve. Akár a középkorban, a fejedelemség korában is a protonotariusok amolyan "mozgó hiteleshelyként" is tevékenykedtek, megbízásaik folytán gyakran jártak az ország különböző területein, ügyfeleik számára lehetôvé téve a bevallást. Míg a káptalant vagy a konventet minden esetben fel kellett keresni, addig az ítélőmester kiszállhatott a helyszínre is. ${ }^{139}$

Az oklevelek ára a protonotariusok számára komoly jövedelmet hozhatott, de bevételüket alkalmanként a dijak szabálytalan emelésével is kiegészítették. Ezért - vélhetően a rendek panaszára - János Zsigmond már 1561-ben "tudós személyekkel meg iratta vala az leveleknek árrát", majd ezeket a díjszabásokat az 1569. évi országgyűlési végzésekben rögzítették, hogy „,az mesterek is meg ne bántassanak az ü igaz jövedelmek felől, mi is meg ne fáradjunk az leveleknek kétszer való árra megfizetésébe". ${ }^{140}$ Ugyanakkor a káptalanok és konventek által kiadott oklevelek árát is megállapították, lényegében átvéve az 1435. évi decretum maius levélárakra vonatkozó X. cikkelyét, eltekintve attól, hogy a János Zsigmond fennhatósá-

\footnotetext{
${ }^{136}$ Az erdélyi protonotariátus kialakulásáról, illetve arról, hogy 1519-től Szapolyai erdélyi kancelláriája tükörképe a királyi udvar központi kormányszervének, lásd Jakó: Vajdai kancellária 42-44.; A kúriai ítélőmesterek hiteleshelyi jellegü tevékenységéhez lásd Bónis: A jogtudó értelmiség 281-282., 381-383.

${ }^{137}$ Vö. KvNLt, Bánffy lt nr. 28/1. (régi jelzet: fasc. Va); SzT V. 850, IX. 156.

${ }^{138}$ Pécsi: Fejedelmi kancellária 65., 77-78.

${ }^{139}$ Vö. Bónis: A jogtudó értelmiség 382.

${ }^{140}$ EOE II. 355-360.
} 
ga alá tartozó területen ekkor már csak a váradi (szekularizált) hiteleshely végzett teljes körü oklevéladó tevékenységet. ${ }^{141}$

A Báthoryak alatt protonotariusként tevékenykedő Radvánczy Márton valamelyik deákja által vezetett formuláskönyv alapján arról is képet alkothatunk, hogy milyen mértékű és jellegű lehetett az ítélőmesteri oklevélkiadás. ${ }^{142} \mathrm{~A}$ formuláriumba az ítéletlevelek és parancslevelek mellett nagyobb részben Radvánczy előtt kelt, a fejedelem nevében kiállított bevallásokat (birtokcserék, egyezségek, egyezség visszavonása, életkor-megállapítás, adásvétel, tiltakozás, zálog, bevallás visszavonása stb.) vezették be. Külön kérésre az ítélőmester még azt is megtehette, hogy vajdai embereket küldjön ki ügyvédvallás felvételére, mint például Glezsán Kristóf feleségéhez, Mikó Fruzsinához, aki a távolság és asszonyi állapota miatt elébe vagy más hiteleshely elé nem járulhatott. ${ }^{143} \mathrm{Az}$ oklevelek jelentős része az ítélőmester caput bonorumának számító birtokán, a Küküllő vármegyei Abosfalván kelt, tehát ott, ahol a legtöbbet tartózkodott.

Az ítélőmesterek előtt kelt oklevelek szerkezete megegyezik a hiteleshelyi kiadványokéval, megerősítésük a fejedelemnek a protonotarius kezénél levő kisebb, bírói pecsétjével történt. A keltezésben mindig egyházi ünnep szerepel, akár a hiteleshelyek által kiadott oklevelekben. A jobb oldalon, a szöveg alatt többnyire azt is feltüntették, hogy melyik ítélömester előtt történt a bevallás. ${ }^{144}$

Az ítélőmesterek mellett a felek a nagyobb kencelláriát is igénybe vehették ahhoz, hogy ügyleteiket írásba foglaltassák. Ezt a tényt már Pécsi Anna megállapította, véleményünk szerint azonban részben tévesek a rá vonatkozó következtetései. Szerinte ugyanis ezeket a kiadványokat „csak akkor erősítették meg fejedelmi és kancellári aláírással, ha privilegiális formában adta ki a kancellária, a többieket a protonotariusok ellenőrizték" ${ }^{145}$ A nagyobb kancellária vezetője azonban a kancellár (mellette vagy hiányában a titkár), ezért valószínútlennek tünik, hogy a nagyobb kancellárián kiállított fassionális okleveleket valamelyik ítélőmester ellenőrizte. Az általunk vizsgált XVI. századi kiadványok alapján egyértelműen arra követ-

\footnotetext{
${ }^{141}$ Zsigmond király 1435-ben kelt szabályozását lásd Decreta Regni Hungariae. Gesetze und Verordnungen Ungarns 1301-1457. Collectionem manuscriptam Francisci Döry. Additamentis auxerunt, commentariis notisque illustraverunt Georgius Bónis, Vera Bácskai. Bp., 1976. 267-269.

${ }^{142}$ MOL F15/12.

${ }^{143}$ Uo. p. $48 .:$,"eadem cum ob loci distantiam tum vero ob muliebris sexus conditionem et fragilitatem nostram in presentiam, vel alium locum credibilem pro constituendo procuratoribus venire nequeat".

${ }^{144} \mathrm{Az}$ 1577. március 13-án, Báthory Kristóf nevében kiállított, bírói pecséttel megerősített bevallás (végrendelet) szövege alatt: „Coram me magistro Stephano Dobzay de Kereztwr prothonotario illustrissimi principis Transsylvaniae". Lásd ErdKirKv VII/3. 91. sz.

${ }^{145}$ Pécsi: Fejedelmi kancellária 52.
} 
keztethetünk, hogy a bevallás vagy a kancellár előtt, vagy, távollétében, a kancelláriai titkár előtt történt. ${ }^{146}$ Báthory Zsigmond királyi könyveiben összesen tíz olyan átírt és megerősített oklevelet találtunk, melyek biztosan a nagyobb kancellária hiteleshelyi tevékenységének termékei; ezek közül mindeniket a kancellár látta el kézjegyével, és valószínü, hogy a fejedelem nagyobb pecsétjével voltak megerősítve. ${ }^{147} \mathrm{~A}$ kiadványok kivétel nélkül pátens alakban keltek.

Hogy valamelyest következtetni tudjunk a kisebb kancellária (ítélőmesterek) és a nagyobb kancellária (kancellár) által folytatott hiteleshelyi oklevéladás közötti arányokról, Báthory Zsigmond említett királyi könyvei alapján azt is megvizsgáltuk, hogy hány esetben köthetjük az átírt bevallások kiállítását egyértelműen az ítélőmesterekhez. Számításaink szerint 14 alkalommal látta el kézjegyével a kiadványt valamelyik ítélőmester (a vizsgált időszakban többnyire Radvánczy Márton vagy Borsoló János), tehát többször fordult elő, hogy olyan oklevelet írtak át, melyet az ítélőmesterek állítottak ki. Az arányok azonban sokkal nagyobb eltérést mutatnának, hogy ha minden esetben átíratták volna az ítélőmesteri kiadványokat, és ezeket be is vezették volna a liber regiusokba. A családi levéltárakban ugyanis nagy számban találhatunk ítélőmesterek által kiállított bevallásokat, míg a kancellártól ellenjegyzett fassióra csak elvétve akadhatunk. Véleményünk szerint inkább ezek a levéltárak tükrözik a valós arányokat, és ezt támasztja alá az is, hogy a nagyobb kancellárián tevékenykedő Jacobinus János formuláriumában csak „kevésszámú oklevél tükrözteti a fejedelmi kancellária hiteleshelyi működését" ${ }^{148}$

\footnotetext{
${ }^{146}$ 1569-ben Valkai Miklós Csáky Mihály főkancellár előtt tiltakozik, lásd ErdKirKv VII/1. 186. sz. 1570-ben a János Zsigmond kancelláriája előtt ellentmondást tevőket szintén Csáky idézi meg határidőre. Uo. 236-237. sz.

${ }^{147}$ ErdKirKv VII/3. 167., 249., 307., 735., 740., 755., 784., 847., 1203., 1517. sz. A kancellár előtt bevallást tevők közül hat esetben valamelyik fél tanácsúr volt, de a maradék három esetben is biztosnak tekinthetjük az udvarral való szoros kapcsolatot (udvari familiáris, kancelláriai íródeák stb.). Akárki tehát nem mehetett ügyével a kancellár elé!

${ }^{148}$ Jacobinus János erdélyi kancellár formuláskönyve (1602). Bevezetéssel és jegyzetekkel közzéteszi Bónis György és Valentiny Antal. Jogtörténeti és népi jogi tanulmányok 2. Kolozsvár, 1947. 24.
} 


\section{A KOLOZSMONOSTORI ÉS GYULAFEHÉRVÁRI HITELESHELYEK ÚJJÁSZERVEZÉSE. AZ 1575. ÉVI INSTRUKCIÓ}

Az előbbi fejezetekben nyomon követtük az Erdélyi Fejedelemség fennhatósága alá került három hiteleshely sorsának alakulását a szekularizációt közvetlenül követő időszakban, illetve röviden bemutattuk azokat az intézményeket, melyek a hiteleshelyeket - az oklevéladó tevékenység beszűkülésének ebben az időszakában - részben, és a későbbiekben is pótolták. A fejedelem és a rendek mindegyik „káptalan” működését különböző módon próbálták megoldani. Mint láttuk, egyedül Váradon tudták biztosítani a viszonylag zavartalan és folyamatos, a külső hiteleshelyi tevékenységet is magában foglaló oklevéladó működést úgy, hogy az eleinte négy, a későbbiekben három requisitor egyike Bihar vármegye jegyzőjének feladatait is végezte. Gyulafehérváron a káptalan helyben maradt, levélkeresőknek kinevezett tagjaira bízták a levéltárat, de itt a nagyobb kancellária által felügyelt hiteleshelyi tevékenység fejedelmi pecséttel megerősített átiratok kiállítására szorítkozott. Kolozsmonostoron az egykori konventi levéltárat a város felügyelete alá rendelték, a világi requisitorok kinevezése viszont elmaradt, a levéltárat a konvent egykori jegyzőjére, a vármegyei nótáriusként is tevékenykedő János deákra bízták.

A kolozsmonostori konvent és a gyulafehérvári káptalan írásos szolgálatának világi alapon való megszervezése végül csak a kezdeti zavaros idők elteltével, 1575 őszén következett be, amikor a kijelölt requisitorokat instrukciókkal látták el, amelyek az újra kibővült, a külső hiteleshelyi tevékenységet is felölelő müködésüket részletesen szabályozták. ${ }^{149} \mathrm{~A}$ két hiteleshelyi levéltár új alapokon való felépítése a már szinte egy évtizede működő váradi mintát követte, és feltehetően az akkori ítélómester, a könyvszerető, jogi ismeretekben jártas értelmiségi, Sulyok Imre nevéhez

\footnotetext{
${ }^{149}$ Jakó: Instrucțiunile 54-56.; A szabályzat annotált változatainak kiadását lásd Sunkó: A Gyulafehérvári Káptalan 79-87.
} 
köthető. ${ }^{150}$ Ő volt az, aki Báthory István fejedelem megbízottjaként, Sombori László jogügyigazgató társaságában 1575 őszén, részletes ügyviteli utasítások kíséretében átadta az iratokat az újonnan kinevezett kolozsmonostori requisitoroknak, a fehérvári káptalan egyik levélkeresőjét pedig az ezen tisztre méltóbb íródeákjával, András deákkal váltotta fel. Ekkor az új személyzet kötelességévé tették, hogy a teljes levéltári anyagot protocollumokba másolják be, az eredetiek változatlan őrzése mellett. Valószínűleg ennek a munkálatnak emlékei Balásfi János gyulafehérvári requisitor másolatai az erdélyi káptalan középkori regisztrumairól. ${ }^{151}$

Hogy miért telt el ilyen hosszú idő a kolozsmonostori konvent és a gyulafehérvári káptalan újjászervezéséig, az vélhetően részben a bizonytalan politikai helyzettel (előbb a Habsburgokkal való harcok, majd Bekes Gáspár lázadása), részint pedig azzal magyarázható, hogy a Királyhágón belüli országrész írásbeliség iránti igényeit nagyobbára kielégítette a két ítélőmester és a fejedelmi kancellária. Ez talán nem meglepő, ha tekintetbe vesszük, hogy a sajátos jogviszonyai miatt is még többnyire szóbeliségben élő székelység, illetve a fejlett, de nagyobbára városi írásbeliséggel rendelkező szászság korábban is a két erdélyi hiteleshely vonzáskörzetén kívül volt, és a requisitorok hivatalba állítása után sem igen vette igénybe azok szolgáltatásait. ${ }^{152} \mathrm{~A}$ hosszas tétovázáshoz bizonyára az is hozzájárulhatott, hogy a hiteleshelyeket a szekularizációval a müködésükhöz szükséges anyagiaktól is megfosztották, így idő kellett ahhoz, hogy az amúgy is pénzszűkével küszködő központi hatalom az új intézmény fenntartásának terhét magára vállalja.

A konventi és a káptalani hiteleshely helyzetének rendezéséről az 1575. július 25.-augusztus 6. között tartott kolozsvári országgyűlésen hoztak határozatot. ${ }^{153}$ Ekkor mindkét intézmény vezetésével, főrequisitorként vagy conservatorként papi személyeket bíztak meg, és rájuk testálták a

\footnotetext{
${ }^{150}$ Sulyok Imréről bővebben lásd Jakó Klára: Lekcsei Sulyok Imre kancellárról. In: Emlékkönyv Kiss András születésének nyolcvanadik évfordulójára. Kolozsvár, 2003. 191-207.

${ }^{151}$ ErdKápJkv VIII/1. 11.

${ }^{152}$ A székely és szász írásbeliség jellegére lásd Szentpétery Imre: Az erdélyi okleveles gyakorlat jellege. In: Turul 1941. 1-2. füzet. 5-6.

${ }^{153}$ EOE II. 562-563.: „Végeztünk erről is országúl, hogy az monostori conventben requisitorok legyenek, mind penig az fejérvári káptalamban. Az monostori conventben Polyáni Bálint pap legyen előttök, collegái legyenek Zalonkemeni Miklós deák és Márton deák, az kolosvármegyei notárius. Az feirvári káptalamban főrequisitor leszen az ott való plebános Ilosvai Benedek pap, collegái az káplánok, ki mellé szükséges egy notáriust keresni. Ezeket ő nagysága erősen megesküdtesse az hívségre, és külön-külön pecsétet adjon nekik, kiknek autoritások legyen nem csak a requisitióra, hanem minden exequtióra, de úgy, hogy ha kik nem akarnak velek exequáltatni, ennek előtte való mód szerint nemes emberrel is exequáltathassanak. Ő nagysága kegyelmesen viseltesse gondját, hogy az miképen kegyelmesen megígírte, legyen meg ezeknek fizetések azonképen, mint az váradi requisitoroknak, és azon fizetések legyen."
} 
régiek mintájára készített új pecsétnyomók őrzését is; Kolozsmonostoron Polyáni Bálint, Gyulafehérváron az ottani plébános, Ilosvai Benedek látta el ezt a feladatot. Azzal, hogy elöljáróknak egyháziakat neveztek ki, bizonyára a létrehozott új világi intézmény tekintélyét próbálták megalapozni. A későbbiekben azonban szinte kizárólag világi személyzet működtette a hiteleshelyeket, csak kivételesen találunk olyan levélkeresőt, aki ugyanakkor vagy előzőleg lelkipásztori teendőket is ellátott (Csanádi Pál püspökké választásában nem kolozsmonostori requisitori hivatala játszott szerepet, hanem az volt a döntő, hogy az unitárius kollégium tanára, tehát felavatott lelkész volt). A kolozsmonostori konventi levéltár őreinek, az említett Bálint pap mellett, a már korábban is requisitornak javasolt, de hivatalába ekkor lépett kolozsvári jegyzőt, Zalánkeményi Miklóst és Kolozs vármegye jegyzőjét, Kolozsvári Mártont rendelték.

Látszólag eltérő megoldást alkalmaztak Gyulafehérváron, ahol a förequisitornak kinevezett Ilosvai mellé az országgyűlési végzés Szilágyiféle kiadása szerint káplánokat, vagyis segédlelkészeket rendeltek levélkeresőkként. Ugyanazt a forrást Kemény József már korábban kiadta, ott viszont káplánok helyett káptalanok szerepelnek a főrequisitor kollégáiként. ${ }^{154}$ Úgy gondoljuk, hogy ez a helyes olvasat, és ezen vélekedésünket támaszthatja alá az a tény is, hogy források szerint a XVI. század közepe tájától nemcsak magát a hiteleshelyet, hanem - jelentésátvitellel - magukat a hiteleshely tagjait, a requisitorokat is magyarul a káptalan, illetve a konvent névvel illették. ${ }^{155} \mathrm{~A}$ káplánok requisitorként való szerepeltetése bizonyára téves olvasatnak tudható be, ugyanis semmi nem utal arra, hogy az 1575-ben kinevezett levéltárosok, Ilosvait kivéve, egyházi személyek lettek volna. 1580 júliusából a gyulafehérvári hiteleshely teljes személyzetét ismerjük, ekkor Ilosvai Benedek vezette a kancelláriát conservatorként, mellette Pápai Imre jegyző, valamint Laskai János és Bácsmegyei Ferenc tevékenykedtek. ${ }^{156}$ Négyük közül csupán Ilosvairól mondható el teljes bizonyossággal, hogy lelkészként is múködött, sőt ő inkább e minőségében ismert.

Összevetve a kolozsmonostori konvent 1575-ben kinevezett személyzetét a gyulafehérvári hiteleshely 1580-as személyi összetételével, néhány különbséget figyelhetünk meg. Először is a káptalannál négy levéltárost

\footnotetext{
${ }^{154}$ Erdélyország történetei tára. Egykoru s magyar nyelven készitett történet-iratok-, levelek-, országgyülési végzések- és törvényczikkelyekből. Kiadják gróf Kemény József és Nagy Ajtai Kovács István. Első kötet 1540-1600. Kolozsvártt, 1837. 147-148.

${ }^{155}$ Szabó T. Attila: Nem vagyok káptalan. In: A szó és az ember. Válogatott tanulmányok, cikkek II. Bukarest, 1971. 49-51. Vö. SzT VI. 139., VII. 200. (káptalan és konvent szócikk). A kolozsmonostori konvent requisitorait olykor még „kolozsvári káptalan uram”-nak is nevezték.

${ }^{156}$ Gálfi Emőke: Az aradi káptalan regisztrumtöredéke és regisztrumának elöszava. In: Erdélyi Múzeum LXXII (2010). 3-4. füzet, 185-196. (Laskai életrajzával). Bácsmegyei Ferenc korábban Fehér vármegye alispáni tisztjét viselte, lásd ErdKirKv VII/1. 342., 359. sz.
} 
találunk, akik közül Pápai Imre jegyzőként tevékenykedik. Ez a külön nótáriusi hivatal a későbbiekben megszűnt, feltehetően azért, mert a requisitorok egyúttal jegyzői feladatokat is végeztek. Az intézményt mindkét helyen egy-egy pap vezette, Kolozsmonostoron mellé requisitornak két jegyzőt: a városit és a vármegyeit rendelték, ezzel mintegy jelezve a hiteleshelynek a városhoz és megyéhez füződő szoros kapcsolatát, amely a későbbiekben is jellemzi a konvent müködését.

Nem tekinthettük feladatunknak a fejedelemség korában tevékenykedő gyulafehérvári levélkeresők jegyzékének összeállítását, ${ }^{157}$ e rövid áttekintéssel csupán szemléltetni akartuk, hogy milyen személyzet végezte a hiteleshelyi tevékenységet az 1575. évi instrukciót követően azért, hogy a kolozsmonostori hiteleshely személyi összetételével való összehasonlítást megkönnyítsük. A káptalani levéltár őrei a XVII. század folyamán is többnyire a gyakorlati jogban jártas, alapos képzettséggel rendelkező hivatalnokok, akik alkalmanként (és párhuzamosan) a fejedelmi központi adminisztrációban is szerepet vállaltak. ${ }^{158}$

Az 1575. év őszén kelt instrukció részletekbe menően szabályozta a világi alapokon újjászervezett kolozsmonostori és gyulafehérvári hiteleshelyek müködését. Összeállításakor részben a már évek óta működő váradi hiteleshely mintáját követhették, részben - bizonyos újításokkal - a bevált középkori gyakorlathoz tértek vissza. A kolozsmonostori levéltár leltár szerinti átadását a kinevezett levélkeresők kezébe Sombori László fiscalis directorra és Sulyok Imre ítélőmesterre bízták. Mindketten a központi fejedelmi adminisztrációnak alapos jogi képzettséggel rendelkező alakjai. Sulyok ítélőmesterként gyakorlattal is rendelkezett a hiteleshelyi jellegü oklevéladásban.

A rendelkezés 21 pontjából hat vonatkozik a levélkeresők elnevezését is adó tevékenységére, a hiteles levéltári másolatok kiállítására, illetőleg az igényelt jogbiztosító iratok megtalálását elősegítendő, a levéltár rendjének biztosítására. ${ }^{159}$ Feladataik közé tartozott a levéltárban őrzött anyag protocollumba való másolása, a par-példányok megőrzése és rendezése. A másolatokat a nótárius egyedül nem állíthatta ki, ha az eredetit a conservator (aki a pecsétet és valószínúleg a levéltár kulcsát is őrizte) megtalálta, mindnyájan össze kellett, hogy gyưljenek, hogy össze vethessék „,az originalokkal a transumptumokat". Minthogy a kinevezett levélkeresők nem laktak a „káptalanban”, az instrukció megengedte, hogy az átírandó oklevelek eredetijét szállásukra vihessék, de azokat „post transumptionem mindgiárast helyekre vidgienek".

\footnotetext{
${ }^{157}$ A gyulafehérvári requisitorok sok szempontból kiegészíthető archontológiáját Sunkó Attila állította össze, lásd Sunkó: Archontológia 297-313.

${ }^{158}$ Vö. Sunkó: Debreceni János 305-343.

${ }^{159}$ Jakó: Instrucțiunile 54-55. (2., 6., 9., 14-16. pontok).
} 
A káptalan és a konvent külső hiteleshelyi tevékenységét négy pontban szabályozták (3-5, 7), ezek közül a legelső a hatókörre vonatkozik: „Hogy a Conventnek a mennyire regenten hatarok volt migh iarhattanak az Országhban és Magiar Országhban, Executioban addigh iarhassanak, tovabb ne, hogy a Feiervári Captalannak is legien bizonyos helyek, hol exequalhassanak" ${ }^{160}$ Minthogy a két hiteleshely külső tevékenységének elhatárolására vonatkozóan semmilyen korábbi rendelkezést nem ismerünk és vélhetően ilyen nem is volt, az instrukció szerkesztőit csupán az a szándék vezérelhette, hogy a korábbi gyakorlat szerint a konvent az északi, a káptalan pedig a déli vármegyékben járjon el. ${ }^{161} \mathrm{~A}$ konvent fejedelemség kori hatókörének kérdését a következőkben részletesebben fogjuk tárgyalni, és ennek során sort kerítünk a középkori helyzettel való összehasonlításra is.

A szekularizáció előtti gyakorlathoz képest újítást hozott az instrukció negyedik pontja, amely megengedi, hogy a peres eljárások során az idézést (evocatio) „egyik az captalanok közzül” hajthassa végre. A különbség akkor tűnik fel, ha összevetjük ezt a rendelkezést az ötödik pontban foglaltakkal, amely megerősítve a régi szokást, kiköti, hogy „egieb executiokban tudniilik statutiokban, hatarjarasban, communis inquisitio dolgaban vajvodalis legien mellette" ${ }^{162} \mathrm{Az}$ idézéseket tehát a vajdai emberek mellőzésével a hiteleshelyi kiküldött egyedül is végezhette, habár a Werbőczy által összeállított törvénytár megfogalmazása szerint „minden perbehívást pedig a király vagy nádor és valamely hiteles hely embereinek kell véghezvinniök" ${ }^{163}$ Arról, hogy a perbehívások gyakorlata megváltozott, Báthory Zsigmond 1580-as években kelt parancslevele is tanúskodik, amelyben - vajdai emberek kijelölése nélkül - arra utasította a váradi levélkeresőket, hogy idézzenek udvarába egy rágalmazót. ${ }^{164}$

Az instrukciónak a bevallások felvételére vonatkozó pontjai (11-13.) leszögezték, hogy a továbbiakban a levélkeresők bármilyen ügyletről oklevelet adhatnak, a díjak megállapításában pedig a Zsigmond decretumában foglaltakhoz kell tartaniuk magukat. A pecsételést a rendelkezés két pontja $(8,10$.$) szabályozza: pecsételni csak együtt, mindenik requisitor jelenlé-$ tében szabad, a pecsét pedig a régi formájára legyen elkészítve, de véssék

\footnotetext{
${ }^{160}$ Uo. 54.; Sunkó: A Gyulafehérvári Káptalan 79-80.

${ }^{161}$ Az instrukciót 1650 táján jegyzetekkel ellátó requisitor a területi hatáskörre vonatkozóan semmilyen intézkedést nem ismert, „,hanem aki hozzá érkezik, menten megy". Lásd Sunkó: A Gyulafehérvári Káptalan 80.

${ }^{162}$ Jakó: Instrucțiunile 55.

${ }^{163}$ Tripartitum 278-279.: „Omnis autem evocatio, per regium, aut palatinalem, et alicujus loci credibilis homines, de juribus possessionariis, haereditariis, vel impignoratitiis, atque etiam officiolatibus eorum, qui sunt evocandi, fieri debet."

${ }^{164}$ MOL. F15/12, 42. (Evocatoria Hungaricalis ratione diffamationis).
} 
a pecsétnyomóra az évszámot, „hogi valami külömsegh esmertesség az regi peczettöl". ${ }^{165}$

A 21 pontból kettő (17-18.) a privilegiális oklevelek kiállítását tiltja. Már Papp László is vitába szállt Kemény József azon megállapításával, hogy a gyulafehérvári káptalannál „post secularisationem cessavit quoque usus literalia huius Archivi sigillo pendenti muniendi" ${ }^{166}$ Megállapította, hogy már a Báthoryak korában adtak ki az erdélyi hiteleshelyek privilegiális alakban okleveleket, és ezért úgy vélte, hogy a tiltás csak János Zsigmond uralkodásának idején lehetett érvényben, a Báthoryak alatt már elévült. ${ }^{167}$ A hiteleshelyek újkori történetét feltáró kutató azonban nem ismerte a levélkeresők részére kiállított instrukciót, amely a régi tiltást erősítette meg: „semmi leveleket in formam privilegy ők ne redigalianak”. ${ }^{168}$ A szabályzat és a gyakorlat közti eltérést 1650 táján már maguk a requisitorok sem tudták megmagyarázni, a privilégiumok kiállításának tiltására vonatkozó pontokhoz a következő megjegyzéseket füzték: „Ez dolog, mint s hogy légyen, nem tudom. Mikor az instrukciot az ország írta, talán egy kevés ideig observáltatott: de sem az előtt, sem azután nemigen". ${ }^{169}$ Tény az, hogy igen rövid ideig volt érvényben a tiltó rendelkezés, vagy - akár a szabályzat más pontjait - ezt sem tartották be. A kolozsmonostori konvent 1577 júniusában, tehát kevesebb mint két évvel az instrukció szerkesztése után már állított ki függőpecsétes oklevelet, ${ }^{170}$ a váradi hiteleshely 1579-ben, ${ }^{171}$ a gyulafehérvári 1581-ben járt el hasonló módon. ${ }^{172}$ A privilégiumok kiállításának módjáról, azok külalakjáról az oklevéladást tárgyaló fejezetben még szó lesz.

\footnotetext{
${ }^{165}$ Jakó: Instrucțiunile 55.

${ }^{166}$ Kemény: Notitia 33.

${ }^{167}$ Papp: A hiteles helyek 109-111.; 1566-ban a szebeni országgyülés a váradi levélkeresőknek is tiltotta kiváltságlevelek kiállítását, kikötve, hogy „privilegiumok kiadása az ő felsége cancelláriájára tartassék", lásd EOE II. 327.

${ }^{168}$ Sunkó: A Gyulafehérvári Káptalan 85.

${ }^{169}$ Uo. 85-86.

${ }^{170}$ KvNLt, Függőpecsétes oklevelek gyüjteménye (Documente cu peceți atârnate), nr. 127.

${ }^{171}$ ErdKirKv VII/3. 120. sz.

${ }^{172}$ ErdKápJkv VIII/1. 286. sz.
} 


\section{A KOLOZSMONOSTORI KONVENT FEJEDELEMSÉG KORI LEVÉLKERESŐI}

A hiteleshelyek középkori működésével foglalkozó tanulmányok rendszerint az oklevéladó tevékenység bemutatását követően térnek rá az intézmények személyi összetételének, a hiteleshelyi kancelláriának tárgyalására. ${ }^{173} \mathrm{Ez}$ annak tudható be, hogy csupán az egyes kiadványokban elszórt adatok alapján rekonstruálható valamilyen mértékben a kancellária személyi összetétele. Dreska Gábor helyesen állapította meg, hogy a hiteleshelyek tevékenységének megismeréséhez a kiadványok tanulmányozása révén nyílik meg az út. ${ }^{174} \mathrm{Az}$ ugyan egyértelmü, hogy a kolozsmonostori konvent fejedelemség kori oklevéladó tevékenységének a jellemzése is a kiadványok alapos tanulmányozása által lehetséges, az intézmény történetének megismeréséhez azonban ebben a korszakban már rendelkezésünkre állnak olyan más források (instrukciók, requisitorok levelezése, beadványaik stb.) is, amelyek lehetővé teszik a többnyire három levélkeresőből álló konventi testület személyi összetételének és müködésének részletesebb bemutatását. Már a szekularizáció előtt nem csak magát a hiteleshelyet, hanem magukat a hiteleshely tagjait is a konvent, illetőleg a káptalan névvel illették. ${ }^{175} \mathrm{Ez}$ a jelentésátvitel a fejedelemség kori Erdélyben teljesen helyénvaló volt, minthogy a hiteleshely intézménye az azt fejedelmi megbízás alapján működtető személyzetből, a levélkeresőkből állott. A továbbiakban tehát az 1575 után fungáló „konventek” életútjának és tevékenységének felvázolása által lényegében az intézmény történetét (is) tárgyaljuk.

${ }^{173}$ Kumorovitz: A leleszi konvent; Szakály Ferenc: A szekszárdi konvent hiteleshelyi és oklevéladó múködése 1526-ig. In: Tanulmányok Tolna megye történetéből I. Szerk. Puskás Attila. Szekszárd, 1968. 9-60.

${ }^{174}$ Dreska: A pannonhalmi konvent 128.

${ }^{175}$ Vö. 155. jegyzet 
A kolozsmonostori konvent levélkeresőiről összeállított jegyzékben 33 olyan személy neve szerepel, akik a szekularizációt követően a fejedelmi korszak végéig (tágabb értelemben kb. 1700-ig) a hiteleshely kancelláriájában dolgoztak. Az ő munkájuk eredményeként keletkezett az a tekintélyes okleveles forrásanyag, illetőleg azok a protocollum-kötetek, melyeknek feltárása és közzététele nélkülözhetetlen a kora újkori és újkori erdélyi társadalom alaposabb megismeréséhez. A jegyzékben szereplő személyek közül azok, akik 1575 előtt viselték a levélkeresői hivatalt, csak levéltárosokként, őrzőkként, hiteles másolatok kiállítóiként működtek, az utánuk következő hivatalnokok már a hiteleshelyi oklevélkiadás minden válfaját végezték, ideértve a külső hiteleshelyi tevékenységet is, bár az iktatások, határjárások, tanúvallatások végzésében a hiteleshelyek egyeduralma a szekularizáció után megszűnt. ${ }^{176} \mathrm{Az}$ alábbi fejezetben nem térünk ki az okleveles gyakorlatra és annak jellegére, csupán annak bemutatására szorítkozunk, hogy a levélkeresői munka milyen karriereket, anyagi és társadalmi érvényesülési lehetőségeket biztosított, hol volt e szűk réteg helye a fejedelemség kori hivatalnok-értelmiségiek körében.

\section{1. A konvent szervezete}

Az 1575-ös instrukció mind a hiteleshelyi munka, mind a jövedelmek terén elvileg egyenlőséget biztosított a három levélkereső között. A gyakorlatban viszont a hiteleshely felelős vezetője a latinul conservatornak, magyarul fókáptalannak vagy főrequisitornak nevezett levéltáros volt, aki többnyire saját lakásán őrizte a pecsétet, és felügyelte a többiek munkáját. A kolozsmonostori konvent első conservatora Somogyi Bálint pap volt, őt követhette ebben a hivatalban Kolozsvári Márton deák. A hosszú ideig levélkeresőként tevékenykedő Pálfi István 1648-ban „,conservator sigilli eiusdem Conventus Colosmonostrensis", a következö évben pedig főkáptalan. ${ }^{177}$ A váradi káptalannál 1580-ban Zilahi János viselte a „primarius requisitor"-i címet, 1638-ban pedig Torma János szerepel fókáptalanként. ${ }^{178} \mathrm{~A}$ gyulafehérvári hiteleshely esetében egyedül Debreceni Jánosról tudjuk, hogy 1619-ben főkáptalannak titulálták. ${ }^{179}$

\footnotetext{
${ }^{176}$ EOE II. 562 (1575. augusztus 6.).

${ }^{177}$ MOL F25 (Miscellanea), f. 339., 360.

${ }^{178}$ Békés vármegye hajdana. Írta Haan Lajos. II. kötet. Oklevéltári rész. Pest, 1870. 194-195.

${ }^{179}$ SzT IV. 354 (fókáptalan szócikk).
} 


\section{2. A levélkeresők kinevezése}

Az 1575. évi újjászervezés új korszakot nyitott a kolozsmonostori konventi hiteleshely történetében. A hiteleshely munkájának zavartalan menete ezentúl a kinevezett requisitorok hozzáállásától, felkészültségétól függött. Korábban a konventnek érdekében állott jól kiválasztani jegyzőjét, hiszen a hiteleshelyi tevékenység komoly többletjövedelmet jelentett az amúgy is tekintélyes birtokokkal rendelkező egyházi intézménynek. Ezentúl a fejedelem és a rendek határozták meg a hiteleshelyi levéltárak sorsát, az ő döntésük volt a megfelelő személyzet kijelölése. A levélkeresőket a fejedelem nevezte ki, megbízatásuk pedig feltehetően életfogytig szólt. ${ }^{180}$ A rendek csak a kezdeti, 1575-tel záruló átmeneti időszakban próbáltak szerepet vállalni a requisitorok kinevezésében, de fizetésük terhét mindig a fejedelemre hárították. ${ }^{181}$ Ezáltal a levélkeresők lényegében fejedelmi hivatalnokokká váltak, a levéltárak jellege pedig megváltozott, immár nem csak a hiteleshelyi tevékenység során termelt iratanyagot (kiállított oklevelek par-példányait, protocollumokat), hanem a királyi könyveket, törvénycikkeket, adólajstromokat, tizedbérletjegyzékeket is itt őrizték. Így lett a káptalani és konventi archívum egyúttal Erdély országos iratvédelmi intézménye, részben a kamarai és fiscalis levéltár szerepét is betöltve. ${ }^{182}$

A levélkeresők kiválasztásakor esetenként figyelembe vették a fungáló requisitorok javaslatait, ${ }^{183}$ de minden esetben arra törekedtek, hogy "elégséges tudományú", jogi ismeretekben jártas személyt állítsanak a hivatalba. ${ }^{184} \mathrm{Az}$ új requisitor kinevezéséről a fejedelem a többi levélkeresőt írásban is értesítette, utasítva őket, hogy ezen hivatalra rendelt „collega”

\footnotetext{
${ }^{180}$ Requisitori kinevezést 1665. július 19-ről ismerünk, ekkor Apafi Mihály hivatala elfoglalására utasította Böszörményi István gyulafehérvári levélkeresőt: „Michael Apafi Dei gratia princeps Transilvaniae partium Regni Hungariae dominus et Siculorum comes etc. Egregie fidelis nobis dilecte salutem et gratiam nostram. Hüségedet rendelvén az Fejérvári Captalanban eggyik requisitornak cum sollito sallarium minekokáért kegyelmesen parancsollyuk hüségednek [?], értvén ez kegyelmes parancsolatunkat alkalmaztassa ahoz magát, mennyen be Fejérvárra collegáihoz, juramentumát deponallya és azután lásson dolgához, járjon el tisztiben." Címzés: Egregii Stephano Beoszörmeny de eadem fideli nobis dilecto (Batthyaneum. A gyulafehérvári káptalan levéltára. X. 181.).

${ }^{181}$ A kinevezésekről, a hiteleshelyek helyzetének rendezésével kapcsolatos országgyűlési intézkedésekről lásd Trócsányi Zsolt: Törvényalkotás 212-215.

${ }^{182}$ Jakó: Fejedelmi levéltár 109-111.

${ }^{183}$ Sunkó: A Gyulafehérvári Káptalan 94-96.

${ }^{184} \mathrm{Az}$, hogy többnyire gyakorlott, nem csupán jogi ismeretekben jártas, hanem a levéltárban őrzött - a társadalom nagyobb része számára hozzáférhetetlen - iratok olvasásához, írásához értő személyek kerültek e hivatalba, eredményezhette a káptalan mindentudóságának hiedelmét, a Nem káptalan a fejem, hogy mindent tudjak szólás kialakulását.
} 
társukat fogadják be testületükbe. ${ }^{185} \mathrm{Az}$ állásért folyamodni is lehetett, így tett például egy ismeretlen nevü (talán Majadi László) váradi levélkereső, aki a fejedelemtől az 1595-ben titkárnak kinevezett Váradi Lukács (fö) requisitor hivatalát és fizetését kérte. ${ }^{186} \mathrm{~A}$ requisitorok hivatalba állítása a többi requisitor jelenlétében egy ítélőmester, a kancellár vagy egy fejedelmi titkár előtt felesketéssel történt. ${ }^{187}$ Ezzel lényegében az instrukcióban foglaltakat erősítették meg.

\section{3. Jövedelmek}

Az 1575-ben megállapított fizetés tisztes megélhetést biztosított a requisitorok számára. Mindegyikük évente $50 \mathrm{Ft}$ készpénzt, 20 köböl búzát, két hordó bort, két vágódisznót kapott, melyhez egy dézsmakerület jövedelme járult. ${ }^{188} \mathrm{~A}$ juttatásokat tehát részben készpénzben, részben pedig

${ }^{185}$ 1659. július 3-án Barcsai Ákos fejedelem levélben értesíti a gyulafehérvári requisitorokat arról, hogy „Arkosi Benedek hívünket edgyk collega társává rendelvén, szegény Papai János hellyet, az ki is erős hittel az nemes országh előt juramentumát deponalta azon hivatallyában való hüségesen el járására. Minekokáért hüségteket kegyelmesen intjük s parancsollyuk is megh nevezet Arkossi Benedek hívünket edgyk káptalan collega társának ismérje s agnoscallya és mindenekben az közönséges jókban és minden le[gitima] ... executiokban és hivataljához illendő alkalmatosságban edgyet ércsen velle. Secus non facturi". (Batthyaneum. A gyulafehérvári káptalan levéltára. X. 55).

${ }^{186}$ Sas Péter: A bonchidai Bánffy-kastély egykori kéziratgyüjteménye. In: Magyar Könyvszemle 2008/1. 61.

${ }^{187}$ Trócsányi: Kormányhatósági levéltárak 125-126. Az esküszöveg kiadását lásd Jakó: Instrucțiunile 56; Az eskü szövege XVII. századi másolatban: „Én T. mostani kegyelmes fejedelem urunk rendelése szerént való Colos-Monostori convent, esküszöm egy Istenre, menynek, földnek, tengernek és minden azokban lévőknek szent teremtőjére, hogy az én tisztemben jó lelki ismerettel és hűséggel járok, a Conventben lévő, ékedig be adatott és ezután be adandó dolgokat fassiókat, leveleket és írásokat titokban tartom és oltalmazom. Legitimum mandatum nélkül ki nem adom, írásom, szollásom, még intésem által is, semmi módon és okon ki nem jelentem. Legitimum requisitorium és executorium mandatum jövén penig hozzám, azoknak kívánsága szerént az mit fel kell keresnem, keresem és feltalalván, mind[en] hiba, hozzá adás, elvétel és változtatás nél[kül] írom le, úgy is adom ki. Minden legitima executiokban mindenüt mindenkor igaz és hủ l[á]tó halló és referens bizonság lészek. Conventbeli pecséttel tisztbeli társaim híre és jelenléte nélkül nem pecsétlek. A pecsét tartásra köz hely lévén, ott tartom és azt társaim akaratjok ellen magamhoz nem vészem, nálam sem tartom. Az egy procuratoria constitution kívül semmi egyéb fassiót edgyedül be nem vészek. Isten úgy segéljen és úgy idvözítsen". (Batthyaneum. A gyulafehérvári káptalan levéltára VIII. doboz, 255. sz).

${ }^{188} \mathrm{Az} 50$ Ft-ban megszabott juttatásukat időnként csak nagy késéssel kapták meg, illetve az eredetileg megállapított összeget I. Rákóczi György idején 33 Ft-ra és 33 dénárra csökkentették. 1664-ben Szalárdi fizetése is ennyi volt, lásd KmProt XXXVIII. $7^{\mathrm{V}}-8^{\mathrm{r}}$. Sombori László tizedfőarendátor 1587-1589 közé keltezhető dézsmaelszámolásában a három kolozsmonostori requisitor összesen $90 \mathrm{Ft}$-tal szerepelt. Az ugyancsak nehezen dönthető el, hogy ez a kiadás egy évre vagy esetleg hosszabb időre vonatkozik-e. Lásd Jakó: Dézsma 74. A későbbiekben nem találtunk utalást arra, hogy a dézsmából részt kaptak volna a requisitorok, ez a juttatás 
terményekben kapták meg. Az 50 Ft-os összeg, figyelembe véve az 1625. évi Bethlen-féle limitáció adatait, tekintélyes summának minősíthető: négy jó, borjas tehenet; két pár ökröt, 25 db galléros ködmönt ért, vagy egy kőmúvessel legalább három szép, cifrás ajtót csináltathattak rajta. ${ }^{189} \mathrm{~A}$ kolozsmonostori requisitorok pénzbeni jövedelme Kolozs vármegye adójából származott, és az évenkénti két (tavaszi és őszi) adószedés miatt az öszszeget két részletben utalták ki. ${ }^{190} \mathrm{Az}$ őszi kifizetés feltehetően Szt. Márton ünnepe táján történt, legalábbis erre utal egy 1613. évi oklevél, melyben Báthory Gábor utasítja fizetőmestereit, hogy a gyulafehérvári levélkeresők teljes fizetésének fele részét és a terményeket ezen ünnep táján adják ki. ${ }^{191}$

Ez a tekintélyesnek nevezhető, készpénzben kiutalt fizetés a takarékos, a kortársak által zsugorinak tartott I. Rákóczi György uralmának kezdeti szakaszában csökkenhetett 33 Ft-ra és 33 dénárra, és a fejedelemség korában végig ezen a szinten maradt. Részint a fizetés lefaragása, de inkább a kifizetések késlekedése képezte a hiteleshely zavartalan müködésének egyik „impedimentumát” a XVII. században kolozsmonostori levélkeresőként tevékenykedő Pálfi István szerint, aki 1655-ben kelt beadványában arról írt, hogy a levélkeresők fizetése régebben a $60 \mathrm{Ft}$-ot (!) is elérte, most 33 Ft és 33 pénz, melyből alig jut egy napra 10 pénz, és ezt a kis salariumot is csak nagy késéssel vehetik kézhez. ${ }^{192} 1651$-ben - de ezelőtt és ezután

feltehetően megszűnt. Az erdélyi hiteleshelyek helyzetéről 1754-ben jelentést tevő bizottság azonban úgy tudta, hogy a requisitorok fizetése: „juxta specificationem salarii requisitorum antiquam unus eorum accepit florenos Hungaricales 50. tritici cubulos 40 [!], vini urnas 160. sabellicos 2, et unum processum decimalem" (MOL F25, Miscellanea f. 435).

${ }^{189}$ Vö. EOE. VIII. 273-302.

${ }^{190}$ A kolozsmonostori requisitorok 1618-ban társuk, Szőlősi István, Kolozs megyei adószedő (perceptor contributionum) kérésére Bethlen Gábor két nyugtáját protocollumukba másolják: „Extractus brevis super administratione contributionum comitatus Colosiensis in generali comitiis Albae Iuliae ad quartam diem mensis May anno 1617 celebratarum a singulis portae [?] per fl 8 solven. ordin. Factus in dicto comitatu Colosiensi iuxta novam connumerationem connumerantur portae numero 306/ colon. 7. quae super f. 8 computando faciunt f. 2453/60. Pro sumptibus legatorum f. 116/28. Summa facit 2569/88. Administratio. In aerarium illmi. d. principi manibus Jonnis Boncziday administrati f. 1914/60 stb. Salarium supremorum comitum $\mathrm{f}$. 100, vice comitibus et judicialium $\mathrm{f}$. 32, preceptori contributionum $\mathrm{f}$. 12, Requisitoribus Colosmonostrensis iuxta annuentiam suae Cels. singulis $f$. 25, pro anno presentis

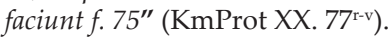

${ }^{191}$ Batthyaneum. A gyulafehérvári káptalan 1t, VI. doboz, 137.

192 "Az Articulusban fizetésünkről is vagyon emlékezet, de nekünk sem Articulus sem az nagyságtok kegyelmes commissioia szerint való fizetést meg nem adják. Az tavali és ez idei salariumunk [res?]tal Zamosuyvarat [...] néhány forint salariumunk jár avval veszünk búzát [...] és egyéb életünkre való táplálását. Adózás [...], gátlás, posta lóadás, tizedelés és egyéb [...] vagyon sine ullo discrimine et respectu [...], mellyen nagy fizetéssel kel végbe vinnünk [?]. Mikor fizetésünköt megadgyák is, salariumunk ami eddig volt is azt se adgyák meg az elmúlt eszt[endőre] Uyvarból. Az néhány forint pinzbeli salariumocskából kel venünk bort, búzát és életünkre való táplálást, ha mikor meg adgyák salariumonkat" (KmProt XXXV. kötet végén, számozatlan lapokon levő fogalmazvány). 
még néhány éven keresztül - csak két konventi requisitor, Kászoni József és Pálfi teljesített szolgálatot a hiteleshelyen. Kettejük fizetése, melyet valóban későn, decemberben vehettek át az utóbb konventi levélkeresőnek kinevezett vármegyei perceptortól, Benkő Bálinttól, kereken 100 Ft-ot tett ki. ${ }^{193}$ Tehát vagy továbbra is $50 \mathrm{Ft}$ volt egy levélkereső salariuma, vagy pedig - és ez valószínűbb - a törvények által megállapított három személyből álló hivatal illetményét (háromszor 33 Ft-ot és 33 dénárt) a szolgálatot teljesítő két requisitornak adták, így „emelkedett” a kézhez vett összeg fejenként $50 \mathrm{Ft}$-ra.

A requisitorok csökkenő készpénzfizetésüket a levelek kiállításáért megszabott illetékek szabálytalan növelésével egészíthették $\mathrm{ki}^{1}{ }^{194}$ de az időnként elvállalt más funkciók (vármegyei adószedő vagy jegyző, városi tisztségek) viseléséért járó salariumok is - nem csekély - pénzbeni juttatással jártak. ${ }^{195} \mathrm{~A}$ három levélkereső az 1575-ben kelt szabályozás szerint elvileg egyenlően osztotta el a levelek taxájából származó jövedelmet: „miérthogy penig commune és egyaránt való az officium mind a három requisitor között: illik és szükséges, hogy mind a munkát egyaránt supportálják, s mind annak a hasznával egyaránt osztozzanak", ez azonban a gyakorlatban nem így történt, ,,sok esztendők alatt csak az (h)uzmi-vozmi [!] dominált, sürgött-forgott a dolog pro arbitrio fortunae at casus momentanei, az mint kik (...) jókban promoveálhatta maga". ${ }^{196}$

A pénzbeni juttatás mellett a jövedelmek másik részét a termények képezték, ezeket a kolozsmonostori levélkeresők rendszerint a szamosújvári fiskális uradalom proventusaiból kapták meg. ${ }^{197}$ Ezekkel részint ellátásu-

${ }^{193}$ KmProt XXXIII. 122v : „Nos requisitores Colosmonostrenses etc. Recognoscimus per presentes [...] egregius Valentinus Benkeo de Colosvar, juratus notarius et perceptorem contributionum comitatus Colosiensis salarium nostrum conventualem, centum florenum hungaricalium constituentem, per illustrissimum dominum principem nobis ex contributione prescripta dari ordinatum, presenti millesimo sexcentesimo quinquagesimo primo anno plene et integre persolvisset. Super quo eundem quietum, expeditum et absolutum [...] testimonio. Actum Claudiopoli die 12 mensis Decembris. Anno 1651 prescripta."

${ }^{194} \mathrm{Az}$ 1640-es években egy tiltakozás kiállítása 2 Ft 97 dénárba, egy bevallás visszavonása pedig 1 Ft 48 dénárba került (KápJegyz 52. doboz). Habár az oklevelek kiállításának díját Zsigmond decretuma alapján - törvényben szabályozták, a gyakorlat azt mutatja, hogy a megszabott pénzösszegeknél gyakran többet elkértek.

${ }^{195}$ Kolozs vármegye perceptorának, a requisitor Szőlősi Istvánnak fizetése 1617-ben 12 Ftot tett ki, lásd 190. sz. jegyzet; 1654-ben Kraszna megye nótáriusának fizetése 16 Ft, az adószedőé ugyanannyi (KvNLt, Bánffy lt nr. 27/2.); 1627-ben Kolozs vármegye jegyzőjének két évre való salariuma jelentős összeget, számításaink szerint kb. 100 Ft-ot tett ki (KolJkv 181 ${ }^{\text {) }}$.

196 Sunkó: A Gyulafehérvári Káptalan 86.

${ }^{197}$ Erre Pálfi István említett beadványa mellett Apafi Mihálynak 1664. július 14-én kelt, Gillányi Gergely föarendátornak, Vizaknai Péter fiscalis praefectusnak és vicearendátornak és a Kolozs megyei perceptornak intézett rendelete is utal: „Colosmonostori Conventbeli három requisitor híveinknek azmint az nemes országh szolgálattjára fizetéseket el rendelvén, arrúl conventiojokat külön külön kiadattuk volt az elmúlt tavaszal Colosvarat létünkben, úgymint 
kat tudták biztosítani, részben pedig pénzzé tehették. Juttatásuk ezen részét is gyakran késve vehették kézhez, 1639-ben például a szamosújvári udvarbíró levelében jelentette Pálfi Istvánnak, hogy a búzát még nem tudja küldeni (a fejedelem ugyanis nagyon sok helyre deputált, a termés pedig gyenge volt), a bor pedig nagyon silány, inkább kérjen máshonnan, mert jobban jár. ${ }^{198} \mathrm{~A}$ bor behozatalát és árulását a városi kiváltságok tiltották, ezért a requisitorok többször is beadvánnyal fordultak a fejedelemhez, hogy valamilyen módon rendezze az ügyet, hiszen emiatt a salariumként járó juttatásuk is csökkent. ${ }^{199} \mathrm{~A}$ városnak ezen törvénye különösen a Várad eleste után családjával együtt földönfutóvá lett, birtokait elvesztő Szalárdi János számára jelentett nagy hátrányt. Szállásának pincéjébe behozott borát le is foglaltatta a város, hiába tiltakozott, hogy ő városi örökség hiányában nem tartozik joghatóságuk alá. ${ }^{200} \mathrm{~A}$ kolozsmonostori konvent requisitorainak nagyobb része viszont vagy törzsökös polgári családból származott, vagy örökséget szerzett a városban. Habár salariumukként járó borukat ők

harminc kis köböl búzáról, százhusz veder borrúl, két két verő sertés marhákról és harminchárom forint s harminchárom készpénz fizetésrül külön külön mind az háromnak. Kegyelmeteknek kegyelmesen parancsollyuk az bor, búza és verő marhákbeli fizetesiket, ha szinte most az németek miatt az Szamosuyvari jószághbeli proventusból, az előtti szokás szerént onnan nem lehetneis, de hozzájok közellyeb levő más fiscalis proventusokból mind búzát, bort, verő marhákat kegyelmetek fő arendator és prefectus hívünk mindenik rendbelit az ő szokott idejekben fogyatkozás nélkül szolgáltassa kezükben, az előtti szokás és rendtartás szerent. Hűséged is penigh perceptor hívünk az adóból pénz fizetéseket adgya megh fogyatkozás nélkül”" (KmProt XXXVIII. $7^{\mathrm{v} \_} 8^{\mathrm{r}}$ ); A gyulafehérvári requisitorok járandóságait a fehérvári udvarbíró adta ki, lásd Sunkó: Debreceni János 309.

${ }^{198}$ MOL F25 (Miscellanea II.), f. 108.

${ }^{199}$ Pálfi István beadványa: „Ezek felett az sem utolsó: hogy az mi borunk járna salariumunk [...] táplálására be nem hozhattyuk, hanem nagy dispendiummal, öt hat vedrével félszeg árron kell el vesztegetnünk itt [?] egy vedrével kell mást vennünk helyében [...] és fizetésünkbeli pénzel, mely azon küvül is csak fa vételünkre sem volna elégh [...]" (KmProt XXXV. kötet végén, számozatlan lapokon levő fogalmazvány). Lásd még Szalárdi János requisitor folyamodványát Kolozsvár városához, hogy salariumaként járó borát a városba behozhassa (Jakab: Oklevéltár II. 387-388.), és Apafi Mihály 1665. február 1-jén kelt utasítását a városhoz, hogy „mivel egyébünent sem várhattja sustentatiójára való commoditását megh nevezett hívünk, ne contrariallja benne sőtt engedgyen tőllünk salariumaban rendeltetett borbeli prebendajával szabadon élést hüségtek" (KmProt XXXVIII. 42.).

${ }^{200}$ "Nobilis et generosus Johannes Szalárdi collega noster conventualis ac solutionum suae Celsitudinis praesidiarium Claudiopolitanarum magister coram nobis personaliter constitutus, per formam solemnis protestationis dicitur quod licet Senatus civitatis usum vinorum suorum a sua Illustrissima Celsitudinae in salarium conventualem datorum, jam antea introductorum et in cellarium hospicii sui repositorum per fas et nefas, prohibere intendissent, eo argumento, ut vel hactenus nullis personis conventualibus huiusmodi vinorum introductio licita fuisset, verum distinctis personis conventualium illorum qui vel hactenus vel ad presens in medio ipsorum civitatum [?] Claudiopolitanorum residentias, domos, vineas, ac alios hereditates possedissent ac jurisdictioni civili omnino subfuissent, a dicti collegae nostri conventualis statu, qui nec ullas hereditates in hac eadem civitate et teritorio illius possideret, nec jurisdictionis civili subesset" (KmProt XXXVIII. p. 111.). 
sem árulhatták a falakon belül, de élvezhették mindazokat az előnyöket, melyeket számukra - hivataluk mellett - a polgári lét biztosított.

Nem lehetett jelentéktelen az a bevétel sem, melyet a requisitorok ajándék gyanánt kaptak az ügyfelektől, főként a régi jogbiztosító iratok előkereséséért és átírásáért. A hiteleshelyi jegyzőket ezek a discretiónak nevezett ajándékok már a középkorban is törvényesen megillették: a levélváltságon felül külön kisebb-nagyobb összeget vagy természetbeni juttatást kaptak. ${ }^{201}$ Ezekről a juttatásokról a levélkeresők a felekkel általában előre megegyeztek, néhány esetben még nyoma is maradt annak, hogy a hálás birtokos miképpen honorálta vagy mit ígért egy-egy átirat kiállításáért. 1643-ban Pécsváradi János fáradozását Miske György Fehér vármegyei birtokos egy pej lóval akarta honorálni, és még azt is kilátásba helyezte, hogy jószágában részt ad neki, ha további leveleket sikerül megtalálnia.. ${ }^{202}$ Lázár István ugyanebben az évben, Tordai Péter levélkeresőhöz intézett levelében, arra

\footnotetext{
${ }^{201}$ KmJkv I. 123-124.
}

${ }^{202} \mathrm{KmProt}$ XXXII. 13 ${ }^{\mathrm{rv} \text { : }}$,„Szolgálatomat ajánlom kegyelmednek mint nekem igen jó akaró fiam uramnak. Isten ő szent felsége áldgya megh kegyelmedet kívánságha szerént sok jókkal. Ez jó akaratirt kidvesiert [?] azirt édes fiam uram nem tudom az kegyelmed jó akarattját én megh szolgálni kegyelmednek, hogy érettem illy nagy fáratságát réám [?] szánta, és kikereste kegyelmed az leveleket, mind [...] együt, noha bizony bánom hogy eddigh is az tabellarius széllel hordozta, nem egyébért, hanem hogy kegyelmeteknek eddigh választ nem írhattam felőle. Atták pedigh megh az levelet nekem, kit kegyelmed írt an[no] 1642 die 5 Decembris, presentis Anno 16 Februarii. Ki kezében forgot nem tudom, egy oláh hozá kezemhez, azon órában el olvasásom után ez levelemet írtam kegyelmednek. Immár értvén hogy az statutoria és az introductoria, hogy Miske Barrabás nevére vagyon találva, mellynek igen örülök, kedvessen is veszük gyermekimmel együt [...]. Az írását pedigh nem kel nekem jó akaró uram sokára hadnod [?], hanem mentül hamaréb írja ki kegyelmed, és megh késülvén értésemre lévén, mikor kész lészen egy pej gyermek lovat küldök kegyelmednek fáratságos munkájáért. Bizony most is oda küldtem volna fiam uram, de tanulatlan, de ki fogattatan és sziligyen küldem megh kegyelmednek. Ha pedigh kegyelmed [...] nálam hadgya is nem difficultalom s jól is tartatom, csak [...] pedigh nem akarom az kegyelmed jó akarattját ez dologban elégh képpen megh elégíteni, hanem az miben nekem parancsol kegyelmed [...] az mire elégh leszek solgálni igyeközöm, gyermekimel egyetemben. Meg is kérem kegyelmedet fiam uram, ha lehetséges volna írná megh kegyelmed nekem mikora küldhetnék utána, noha az kegyelmed jó akarattjában nem kételkedhetem, mint megh mutatta most is kegyelmed hozzám, sőt ha megh nem bántódik kegyelmed az zálogitásról is keresne kegyelmed. Ugyan azon [...] zálogosította el kessebbik Miske András az Bekes hada után sok idővel, én úgy tudom megh hatta kegyelmed, hogy ezt is külön megh fizetvén kegyelmednek jámborul, mégh ha él kegyelmed és én is, részessé is teszem én abban kegyelmedet, mint illyen jóakaromat. Csak ne difficultallja kegyelmed keresni, és az zálaglását is fel keresvén az originallal együt ki írni. Isten tarcsa megh kegyelmedet jó egésségben, megh mutatot jó akarattja után, jó választ várok ez levelemre is kegyelmedtül. De caeteris valet [?] desidero et servitiis semper paratus G.D.V. pater benevolo Georgius Miske mp." [1643-ban beírva, Pécsváradi kezével]. Címzés: Az én jó akaró fiam uramnak, Peczvaradi János uramnak, az Kolosvari Capitulum egyik káptalanjának, nekem jóakaromnak adassék Colosvarat. 
tett ígéretet, hogy bizonyos oklevelek lemásolását „,kegyelmednek emberségesen meghfizetem". ${ }^{203}$

Szintén a requisitori jövedelmekhez számíthatjuk azokat a többnyire kisebb birtokadományokat, melyeket a konventek hüséges szolgálataik fejében a fejedelemtől, illetőleg olykor az elégedett ügyfelektől kaptak. Pécsi Jánoshoz például horgaspataki részjószága requisitori tevékenységének jutalmaként került, ${ }^{204}$ Kászoni Józsefnek pedig azért jutott Rhédei Ferenc tanácsúr részéről egy dési jobbágy, mert a számára szükséges okleveleket a konvent levéltárából előkereste. ${ }^{205}$

A konventi és káptalani levélkeresők fejedelmekhez intézett beadványait, panaszleveleit olvasva az az érzésünk támadhat, hogy a requisitorok terhes hivatalának jutalma csupán a nyomor volt, jövedelmeik igen szűkös megélhetést biztosítottak számukra. Ezzel szemben a valóság sokkalta árnyaltabb lehetett. A válságos időszakok biztosan őket is érintették, de a rátermettek élni és olykor visszaélni is tudtak a tisztségük által biztosított előnyökkel. Most csak egyetlen - talán kissé kirívó - példát hozunk fel állításunk bizonyítására. 1648-ban a Máramaros vármegyei Alsóapsa lakosai arra kérték Pálfi István requisitort, hogy szálljon ki, és a kijelölt regius társaságában állapítsa meg a vitás határokat. Ezért az executióért Pálfi éppen annyit kért, amennyit a visói határjáráskor kapott: „Ide be az exmissiójért f. 12. Az oda való járásomért és az executioról való relatoriaért attak conventioképpen f. 40. Ezen küvül mindenik falu egy egy gyermek lovat, rókát, nestet honorariumba, mellyet ő kegyelmektől én is jó néven vöttem, s jól is ügyekeztem szólgálni [...] Ez mellett kérem kegyelmeteket, nagy bizodalommal, akkorra ha be küld kegyelmetek, fogasson valami szép halakat, pisztrángot, galócát etc. Az Colosvari bíró nekem atyámfia, szintén akkor leszen az fiának menyegzeje, az kegyelmetek emberségével had tisztelkedgyem ő kegyelmének, igen kedvesen veszem kegyelmetektől. Ezzel Isten tarcsa megh kegyelmeteket jó egésségben". ${ }^{206}$ Egy-egy birtok határainak megállapítása valóban sok fáradsággal járt, de ebben az esetben a requisitor munkájának pénzbeni jutalma még a hivatalával járó fizetésének teljes összegét is meghaladta.

Tudjuk azt, hogy a gyulafehérvári hiteleshely levélkeresői jövedelmeik mellett, hivatalviselésük fontosságának jeleként, a hadi szolgálat alól is mentességet élveztek. ${ }^{207}$ A kolozsmonostori konvent requisitorai kolozsvá-

\footnotetext{
${ }^{203}$ MOL F25 (Miscellanea II.), f. 298.

${ }^{204}$ MOL F1. 21. 123 $-123^{\mathrm{v}}$.

${ }^{205} \mathrm{KmProt}$ XXXIII. 80v.

${ }^{206}$ MOL F25 (Miscellanea II.), f. 345.

${ }^{207}$ Erre utal Bethlen István kormányzónak 1620. november 29-én kelt utasítása Fehér vármegyéhez, amely ugyan a gyulafehérvári káptalanra vonatkozik, de ezen immunitással bizonyára mindhárom hiteleshely rendelkezett: „Miel hogy az Feyerwari requisitoroknak mind
} 
ri közteherviselő polgárokként nem kellett, hogy személyesen hadba vonuljanak, de vármegyei birtokaik után (ha rendelkeztek ilyennel), a többi birtokkal rendelkező városi polgárral együtt - jószáguk nagysága szerint - háború esetén katonát vagy felszerelt lovat kellett állítaniuk. ${ }^{208}$

\section{4. Származás, háttér, korábbi pályafutás}

Mielőtt rátérnénk a levélkeresők életrajzi adatainak ismertetésére, szükségesnek tartottuk néhány kérdés felvetését és tisztázását. Legelőször azt vizsgáltuk meg, hogy az ország melyik területéről és milyen társadalmi kategóriákból kerültek ki a konventi requisitorok. A levélkeresők mintegy fele részéről biztosan állíthatjuk, hogy a hiteleshelynek is otthont adó városból, Kolozsvárról származott. A levéltári szolgálat érvényesülési lehetőséget jelentett a város polgárai számára, ennek a hivatalnak a viselése egyúttal a kiváltságolt nemesség körébe való lépésüket is jelentette. A kolozsvári polgárokból lett levélkeresőknek tehát hármas „kötődésük” volt. Egyrészt köztiszteletnek örvendő városi polgárok, másrészt egy jellegzetesen „nemesi” intézmény, a hiteleshely tisztségviselői, de ugyanakkor a központi hatalom, a fejedelem fizetett „,szolgái” is. Erre a helyzetre és a város életében betöltött szerepükre a továbbiakban még részletesebben kitérünk.

A kisbirtokos nemesek közé öt nevet sikerült besorolnunk, Hajósi Pált, Szőlősi Istvánt, Szamosközi Mihályt, Szalárdi Jánost és Virginás Istvánt. Az első három valószínűleg környékbeli birtokos család tagja (Hajósi biztosan a Kolozs megyei Magyarpatán birtokolt), Szalárdi és Virginás viszonylag távoli vidékről, Biharból került a hiteleshelyhez, mindkettő fejedelmi utasításra. Jelentős arányban vannak jelen a requisitorok között a székelyek (Kibédi János, Bibarcfalvi János, Demeter János, Benkő Bálint). ${ }^{209}$ Az értelmiségi pálya jelentette számukra talán az egyetlen érvényesülési és emelkedési lehetőséget. Három levélkeresőről sikerült megállapítani, hogy mezővárosi származású: Pálfi István Enyedről, Kászoni József a Bereg vármegyei Kászonyról, Tordai Imre pedig a közeli Tordáról került a

az előt, s mind ez mostani kegyelmes királyunk ő felsége itt ben létében oly immunitasok volt, hogy miel az országh fejedelminek és utánna levő gondviselőknek az minemű kezönséghes országh szükséges dolgai, úgymint inventalás, foglalás vagy egyéb inquisitio és tisztekhez illendő szükséges parancsiolatok érkeztek, és szolgálattjok s kimenetelek valamely felé kívántatot, mingyárast ki menni és azt exequalni tartoztak, azon kivöl is az sacristiaban és országh levelei körül való vigyázásban és gondviselésben szolgálattjok minden napon kívántatván az hadban való menetelre szükségesképpen menni se személyekrül, se jószágokrúl nem kénszeretettek" (KápJegyz III. 314-315.).

${ }^{208}$ Pécsi János egy felszerelt lovat kellett, hogy hadba állítson (KmProt XXIX. 173 $)$.

${ }^{209}$ A nagyobb kancellária íródeákjai között is jelentős számban találunk székelyeket, lásd Trócsányi: Központi kormányzat 204-205. 
hiteleshelyre, közülük kettő hivatalviselése idején kolozsvári polgár lett. Az előbbiek azt bizonyítják, hogy a levélkeresők körében a legjelentősebb társadalmi elem egyértelmúen a városi (kolozsvári) polgárság volt.

Összeállításunk adatai alapján a requisitorok szolgálati idejének átlaga valamivel több, mint 11 év. Több mint 30 évig volt szolgálatban Rákosi Boldizsár, Pálfi István és Szentiványi György. A következő kategóriában 20 év fölötti szolgálati idővel Kolozsvári Márton, Kövendi Mátyás, Tordai Péter és János deák található. Ez utóbbi esetében azonban a hosszas levéltári szolgálat bizonyára azzal magyarázható, hogy ő volt az egyedüli, aki konventi nótáriusként a levéltárat alaposan ismerte, rá feltétlenül szükség volt a lemásolandó oklevelek kikereséséhez. A 10-20 év közötti szolgálatot teljesítők közé Balásfi Ambrust, Csanádi Pált, Kászoni Józsefet, Rákosi Pétert, Tordai Imrét és Vicei Istvánt számíthatjuk, öt év fölött heten, a többiek pedig ennél rövidebb ideig viselték a levélkeresői hivatalt. ${ }^{210}$

A kolozsmonostori levélkeresők szolgálati ideje a fejedelemség korában

\begin{tabular}{|c|c|}
\hline Szolgálati idő & Levélkeresők száma \\
\hline 30 év felett & 3 \\
\hline $20-30$ év között & 4 \\
\hline $10-20$ év között & 6 \\
\hline $5-10$ év között & 12 \\
\hline 5 év alatt & 8 \\
\hline
\end{tabular}

A fentiek alapján az ismert levélkeresők több mint fele 5 évnél hoszszabb ideig teljesített levéltári szolgálatot, és e kategórián belül (5-30 év közötti szolgálati idő) többségük számára ez jelentette értelmiségi karrierjük végállomását. Az 5 év alatti szolgálati idővel szereplők magas száma arra utalhatna, hogy a levélkeresők tekintélyes hányada csak életpályája átmeneti szakaszának tekintette a konventet, nagy részükről azonban valószínüsíthető, illetőleg esetenként bizonyítható, hogy tisztségüket halálukig viselték. A levélkeresői szolgálat tehát - ellentétben a nagyobb vagy kisebb kancelláriai íródeáksággal - általában egy-egy értelmiségi karrier végállomását képezte, de ez nem jelenti azt, hogy ezzel lezárult az út a magasabb és jövedelmezőbb tisztségek felé. ${ }^{211}$ Kolozsvári Márton deák és Virginás István életútja példa arra, hogy a kolozsmonostori hiteleshelyen való szolgálat nemcsak tisztes megélhetést biztosított, de lehetőséget teremtett arra is, hogy a levélkeresők párhuzamosan egyéb, jelentősebb szerepeket is elvállaljanak. Mindkét előbb említett requisitor alapos jogi

\footnotetext{
${ }^{210}$ Vö. Sunkó: Archontológia 290.

${ }^{211}$ A kancelláriai deákság átmeneti jellegéről lásd Trócsányi: Központi kormányzat 200.
} 
felkészültségének és a gyakorlati jogban való jártasságának köszönhetően a fejedelmi táblára került, Kolozsvári előbb ítélőszéki ülnökként, majd ítélőmesterként, Virginás pedig ülnökként. A két életpálya talán csak annyiban különbözik, hogy Virginás már korábban is jelentős tisztségeket (fiscalis director) töltött be, míg Márton deák pályája a legalacsonyabb szinttől, a nótáriusi funkciótól ívelt folyamatosan fölfelé.

A középkor évszázadaiban a konventi kancellária a gyakorlati jogászrend egyik iskolájának számított. A feltörekvő kisnemesi vagy polgári származású írnokok itt olyan magas szintű ismereteket sajátítottak el, melyeket az erdélyi tartományi kormányzatban is kamatoztatni tudtak. ${ }^{212} \mathrm{~A}$ fejedelemség korában a hiteleshelyek és a központi kormányzat közötti szoros kapcsolat továbbra is megfigyelhető, de az írástudók áramlása - a kolozsmonostori hiteleshely esetében - fordított irányú. ${ }^{213}$ Kijelenthetjük, hogy a levélkeresők „iskolájának” a fejedelmi kancellária számított, ott tökéletesítették közülük legalább tizenhatan az oklevelek fogalmazásában és írásában való gyakorlatukat (a nagyobb kancellárián: Csanádi János, Tolnai Miklós, Bibarcfalvi János, Pálfi István, Pécsi János, Pécsváradi János, Tordai Péter, Szamosközi Mihály, Szalárdi János, Szőlősi István; a kisebb kancellárián: Szentiványi György, Kibédi János, Hajósi Pál, Szőlősi István, Kászoni József, Benkő Bálint). Ha a nagyobb kancellárián szolgálatot teljesítők közül leszámítjuk azokat, akiknek neve csak a kezdeti szabályozatlan időszakban (1575 elött) fordul elö, és valószínüleg nem is müködtek requisitorként, megállapíthatjuk, hogy lényegében azonos arányban volt a kolozsmonostori hiteleshelyi levélkeresők életpályájának előző színtere a kisebb és a nagyobb kancellária. Ez ugyanakkor arra is utalhat, hogy a hiteleshelyi archívum levélkeresői hivatala nagyobb tekintéllyel bírt, és jelentősebb jövedelmet is hozhatott a kancelláriai jegyzőségénél.

Mint láttuk, már a szekularizáció előtt bevett gyakorlatnak számított az, hogy a felek valamelyik ítélőmesterhez fordultak azzal a kéréssel, hogy őrizze meg okleveleiket, vagy foglaltassa írásba bevallásukat. A protonotáriusok - feltehetően írnokaik által kísérve - gyakran járták az országot, így alkalmanként elérhetőbbnek bizonyultak egy-egy hiteleshelynél, melyet minden esetben fel kellett keresni. Ezt a hiteleshelyinek minősülő tevékenységet a fejedelemség korában a kisebb kancellária folytatta, melynek vezetői az ítélőmesterek voltak. Különféle jogi ügyletekről kelt bevallásokat, tiltakozásokat, egyezségeket foglaltak írásba, melyeket a fejedelem

${ }^{212}$ Sipos: Kolozsmonostor 45.; Jakó: Vajdai kancellária 42-61.

${ }^{213}$ A gyulafehérvári káptalan levélkeresőinek feltehetően tekintélyes hányada egyszerre teljesített szolgálatot a hiteleshely és a fejedelem kancelláriáján, lásd ErdKápJkv VIII/1. 16-18. 
nevében, de a bírósági pecséttel megerősítve állítottak ki. ${ }^{214}$ Ezen oklevelek szerkezete, szövegezése mindenben megegyezik a hiteleshelyek által használt formulákkal, a kisebb kancellárián tevékenykedő íródeákoknak tehát egyáltalán nem okozhatott nehézséget a konventi hivatali szolgálatra való áttérés.

\section{5. Képzettség}

Kérdésként merül fel, hogy milyen képzettség volt szükséges ahhoz, hogy valaki a hiteleshelyi „kancelláriára” kerülhessen. Valószínűnek tekinthetjük, hogy e képzés alapjait valamelyik (többnyire a kolozsvári) városi iskolában fektették le, további külföldi, egyetemi tanulmányokra nemigen volt szükségük ahhoz, hogy gyakorlatias jellegü munkájukat jól végezhessék. Ehhez inkább többéves írnoki munka kellett a fejedelem valamelyik kancelláriáján. Nem meglepő, hogy csupán négy levélkeresőről tudjuk azt, hogy külföldön is képezte magát, és négyükből kettő a felhalmozott tudást a helyi unitárius kollégiumban adta tovább, ahol tanárként tevékenykedett (Csanádi Pál és Rákosi Boldizsár).

\section{6. Felekezeti megoszlás}

Viszonylag kései, 1711-es adat alapján lehet arra következtetni, hogy a levélkeresők kiválasztása lehetőség szerint úgy történt, hogy valamenynyi bevett felekezet képviselve legyen a levéltár őrzésében. ${ }^{215}$ Nem tudjuk, hogy mennyiben tartották magukat a fejedelmek ehhez az elöíráshoz (ha volt ilyen egyáltalán), hiszen csak néhány requisitor vallását sikerült megállapítanunk. A fentebb említett Csanádi Pál és Rákosi Boldizsár nyilván unitárius volt, és ezt feltételezhetjük a kolozsvári polgárcsaládokból származó többi „konventről” is (Balásfi Ambrus, Kövendi Mátyás, Szentiványi György, Szőlősi Gábor, Lutz István). Kolozsvári Márton katolikus vallású lehetett, csakúgy, mint Pálfi István, aki talán a jezsuiták kolozsmonostori iskolájában nevelkedett, ${ }^{216}$ és Szamosközi Mihály, a kolozsmonostori ka-

\footnotetext{
${ }^{214}$ A kisebb kancellária ilyen jellegű tevékenységéről lásd Pécsi: Fejedelmi kancellária 65. Itt említjük meg, hogy az ítélőmesterek formuláriumokat is használtak az oklevéladáshoz. A valószínűleg Radvánczy Márton valamelyik íródeákja által vezetett formuláskönyv bejegyzései arról tanúskodnak, hogy az ítélőmesterek igen nagy számban állítottak ki hiteleshelyi jellegú okleveleket. Jelzete: KmProt XII.

${ }^{215} 1711$. december 3-án a Gubernium a kolozsmonostori requisitori hivatalra Rákosi Péter mellé a reformátusok és a katolikusok részéről Vizaknai Györgyöt és Horvát Mártont rendelte, lásd Beke: A kolozsmonostori konvent 648. sz.; Trócsányi: Kormányhatósági levéltárak 126.

${ }^{216}$ Jakó Klára: Betűművész 37-38.
} 
tolikusok egyik aedilise. Szalárdi Jánosról, Laki Péterről és Vicei Istvánról sikerült egyértelműen megállapítani, hogy reformátusok voltak. Laki gyakran képviselte egyháza érdekeit az unitáriusokkal folytatott tárgyalásokon, Szalárdi és Vicei pedig a kolozsvári református egyházközség kurátoraiként tevékenykedtek. ${ }^{217}$

\section{7. A requisitorok és a város}

Az előbbiekben már hoztunk példákat arra, hogy a requisitorok egy (tekintélyes) része hivatalviselése ideje alatt jövedelmét kiegészítette más hivatalok elvállalásával, részben a hiteleshelynek is otthont adó városban, Kolozsváron, részben pedig a vármegyénél vagy a pénzügyi igazgatásban. Az iskolázott kolozsváriak már a középkorban is szívesen vállaltak állást a város tőszomszédságában levő Kolozsmonostoron, így a konventi jegyzők nagy hányada a városi írástudók közül került ki. ${ }^{218} \mathrm{Ez}$ a jelenség a szekularizáció után, a hiteleshely és levéltár Kolozsvárra való költöztetésével természetesen tovább erősödött, az ismert requisitorok közül legalább tizenhétről biztosan állíthatjuk, hogy városi polgárok voltak, és gyakran a városvezetésben és igazgatásban is szerepet kaptak.

\section{A kolozsmonostori levélkeresók kolozsvári tisztségei}

\begin{tabular}{|l|l|}
\hline \multicolumn{1}{|c|}{$\begin{array}{c}\text { Levélkereső neve } \\
\text { és szolgálati ideje }\end{array}$} & \multicolumn{1}{|c|}{ Kolozsvári hivatalviselés ideje } \\
\hline Zalánkeményi Miklós 1575-1576 & jegyző 1569-1576 \\
\hline Kolozsvári Márton 1575-1600 & százférfi 1577 \\
\hline Kövendi Mátyás 1593-1614 & director 1603; százférfi 1603, 1606 \\
\hline Tordai Imre 1608-1619 & százférfi 1608, 1617; számvevő 1613, \\
& 1616; quarta gondviselője 1619-1620 \\
\hline Tordai Péter 1627-1646 & százférfi 1623, 1642 \\
\hline Pálfi István 1627-1667219 & százférfi 1640, 1642, 1647 \\
\hline Pécsi János 1633-1642 & százférfi 1623 \\
\hline
\end{tabular}

${ }^{217}$ Laki Péterről lásd Sipos: Kollégiumi könyvtár 57-58.; Szalárdi kurátorságára lásd Herepei: Adattár I. 550.; Vicei egyházgondnoki szerepére lásd Kolozsvári Református Egyházközség lt (az Erdélyi Református Egyházkerület lt-ban) 2. IV. 2. Az adatra a kolozsvári református egyházközség XVII. századi gazdálkodását feldolgozó Szász Anikó hívta fel figyelmemet.

${ }^{218} \mathrm{KmJkv}$ I. 121.

${ }^{219}$ Pálfi Istvánról tudjuk, hogy a Fehér megyei Enyedről származott, tehát nem helybéli polgárcsalád sarja, de hosszú hivatalviselése alatt városi örökséggel rendelkező, a közösség által megbecsült polgárrá vált. 


\begin{tabular}{|l|l|}
\hline Benkő Bálint 1654-1661 & százférfi 1653-1661; számvevő \\
& 1654-1655, 1657-1659; adószedő (rend- \\
& kívüli adó) 1660; divisor 1661 \\
\hline Szőlősi Gábor 1654-1657220 & dispensator 1651; számvevő 1652-1653, \\
& 1659-1660, 1665; esküdt 1654; százférfi \\
& 1648, 1653, 1655, 1659-1665; királybíró \\
& 1657; főbíró 1658; a város egyik gene- \\
& rálisa 1661; ülnök 1667-1668; a város \\
& országgyülési követe 1670 \\
\hline Lutz István 1661-1670 & esküdt 1655, százférfi 1675 \\
\hline Laki Péter 1696-1703 & százférfi 1696-tól \\
\hline Rákosi Péter 1696-1711 & jegyző 1701, 1704 \\
\hline
\end{tabular}

A fenti táblázat adatai arról vallanak, hogy a kolozsmonostori levélkeresők tekintélyes része, több mint 30 százaléka részt vett a városi szűkebb és tágabb vezetésben, illetve egy esetben (ez a későbbi korszakban még megismétlődik ${ }^{221}$ a bírói tisztet is egy levélkereső viselte. Tízen közülük a város felső tanácsának (százférfiak tanácsa) voltak tagjai, ahova csak a legtekintélyesebb és ugyanakkor legvagyonosabb polgárokat választották be. ${ }^{222}$ Természetesen nem gondolhatunk arra, hogy egyedül a konventi szolgálat tette lehetővé a magasra ívelő városi karriereket, csupán annyit állapíthatunk meg, hogy a „káptalanok” a városi közösség megbecsült tagjai voltak, akár törzsökös polgárcsaládból származtak, akár mezővárosokból, vármegyékből vagy a székely székekből kerültek Kolozsvárra. Sikerült tehát szinte mindannyiuknak beilleszkedni a városi közösségbe, örökséget tudtak szerezni, s ezt bizonyára fejedelmi támogatással, de a város jóváhagyásával tehették csak meg. Hivataluk lehetővé tette azt, hogy egyféle közvetítőkként lépjenek fel részint a város, részint a vármegyei nemesség és a központi hatalom, a fejedelmi udvar között.

A városi társadalomba való beilleszkedés azonban nem volt minden esetben akadálymentes. Az élete végén néhány évig konventi levéltárosként tevékenykedő Szalárdi gyakran illette panasszal a város vezetőségét amiatt, hogy amúgy is akadozva fizetett sallariuma kiegészítéséül kapott

\footnotetext{
${ }^{220}$ Szőlősi kisebb jelentőségű városi tisztségeit lásd a 405. sz. jegyzetnél.

${ }^{221}$ Páll Sámuelre gondolunk, aki a XVIII. században kolozsvári főbíróként és konventi levélkeresőként vállalkozott a városi levéltár rendezésére. Róla bővebben lásd Kiss: Források 26-29.

${ }^{222}$ A centumvireknek a város bírósági gyakorlatában betöltött szerepéről lásd Pakó László: Rolul adunării centumvirilor în activitatea judecătorească a Clujului în cea de-a doua jumătate a secolului al XVI-lea. In: Pe urmele trecutului. Profesorului Nicolae Edroiu la 70 de ani. Coord. Susana Andea, Ioan-Aurel Pop. Cluj-Napoca, 2009. 225-238. Ugyanarról bővebben lásd uő: Hatalmi konfliktus vagy testületi összefogás? A kolozsvári százférfiak tanácsa és a városi igazságszolgáltatás a 16. század második felében. In: Erdélyi Múzeum LXXII (2010). 3-4. füzet, 73-87.
} 
borát a város nem engedte be falai közé. ${ }^{223} \mathrm{~A}$ város az addig alkalmazott gyakorlatra hivatkozott, amely értelmében a konventbeli emberek, akik örökségekkel bírtak a városban, a városi joghatóság alá tartoztak úgy, mint minden városi birtokos. Szalárdi válasza erre az volt, hogy neki öröksége a városban nincs, és polgári igazgatás alá nem tartozik; a törökök minden jószágától és örökségétől megfosztották, hazájából, Váradról elűzték, a fejedelem és a rendek pedig Kolozsvárra küldték. A város különbséget kellene, hogy tegyen „it lakos patricius örökseges conventbeli becsületes szemelyek között, az kiknek külömben is kegyelmetek privilegiumatol, bottyatol kelletven függenijek, s öröksegesek leven, volt s vagyon is miből magokat sustentalniok, ellenben penigh az en romlot, nyomorodot allapotom mas karban vagyon, mert az közönseges haza szolgalattia mellet mindenemet el vesztven, Istennek igaz iteletiből a nyomorusag hozott es szoritott ide kegyelmetek közibe". ${ }^{224}$

\section{8. A requisitorok és a vármegye}

Érdemes arra is kitérni, hogy milyen kapcsolat volt a hiteleshely és esetünkben Kolozs vármegye között. Más hiteleshelyek működésében is előfordult, hogy a vármegyei és hiteleshelyi jegyző ugyanaz a személy volt, így történt ez a XVI. század közepén Zalaváron, ${ }^{225}$ de Váradon, a világi alapon újjászervezett hiteleshelyen is gyakran az egyik requisitor vezette a vármegyei törvényszék jegyzőkönyveit. ${ }^{226} \mathrm{~A}$ XVI-XVII. században a vasvári káptalan jegyzője gyakran nótáriuskodott a vármegyénél is. ${ }^{227}$ Úgy tűnik tehát, hogy nem ritka esetekről, hanem az egész ország területére jellemző

${ }^{223}$ KmProt XXXVIII. $41^{\mathrm{r}}-42^{\mathrm{v}}$.

${ }^{224}$ Jakab: Oklevéltár II. 387-388.

${ }^{225}$ A zalavári és kapornaki konventek hiteleshelyi levéltárainak oklevélregesztái 1542-1544 (szerk. Bilkei Irén). Zalaegerszeg, 2002. 13.

${ }^{226}$ Albert deák 1568-1569-ben váradi requisitor és ugyanakkor vármegyei jegyző lásd ErdKirKv VII/3. 63. sz; Lukács deák 1587-1595 között feltehetően folyamatosan váradi káptalani levélkereső, 1587-1588-ban a vármegye ügyeit foglalja írásba nótáriusként, lásd ErdKirKv VII/3. 724., 835., 1385. sz.; 1599-ben váradi Kis János deák egyszerre tölti be a váradi requisitori, Bihar vármegyei jegyzői és adóperceptori hivatalokat, lásd KmProt X. 448v. Róluk bővebben lásd Bogdándi Zsolt: A váradi hiteleshely a szekularizációt követően. In: Erdélyi Múzeum LXXIII (2011). 3-4. füzet. 104-116.

${ }^{227}$ Kóta Péter: Káptalani, megyei, városi jegyzők a XVI-XVII. századi Szombathelyen. In: Vas megyei levéltári füzetek 9. Előadások Vas megye történetéről III. Szombathely, 2000. 153. A közölt vármegyei protocollumok is a sedriák hiteleshelyi funkcióinak megnövekedését mutatják. Lásd Dominkovits Péter: Vármegyei vezetók, közigazgatási feladatok a 17. századi Sopron és Vas vármegyék példáján. In: Megyetörténet. Egyház- és igazgatástörténeti tanulmányok a veszprémi püspökség 1009. évi adománylevele tiszteletére (szerk. Hermann István és Karlinszky Balázs). Veszprém, 2010. 431. 
gyakorlatról van szó, melynek felderítéséhez a további kutatások valószínúleg újabb adatokat szolgáltatnának.

A levélkeresők Kolozs vármegyei tisztségei

\begin{tabular}{|l|l|}
\hline \multicolumn{1}{|c|}{$\begin{array}{c}\text { Levélkereső neve } \\
\text { és szolgálati ideje }\end{array}$} & \multicolumn{1}{|c|}{ Vármegyei hivatalviselés ideje } \\
\hline János deák 1560 (1552)-1575 & nótárius 1560-1564, 1569-1570 \\
\hline Kolozsvári Márton 1575-1600 & $\begin{array}{l}\text { nótárius 1575, 1579, 1582, 1585, } \\
1587,1590,1593 ; \text { adószedő (?) 1579 }\end{array}$ \\
\hline Kibédi János 1601-1602 & nótárius 1601-1602 \\
\hline Hajósi Pál 1603-1605 & nótárius 1605-ig \\
\hline Tordai Imre 1608-1619 & $\begin{array}{l}\text { nótárius 1605, 1608, 1611, } \\
1616-1617,1622, \text { adószedő 1611 }\end{array}$ \\
\hline Tordai Péter 1627-1646 & adószedő 1623, 1628, 1636 \\
\hline Szőlősi István 1616-1623 & nótárius 1623-1624, adószedő \\
& 1617-1618, 1621-1622 \\
\hline Pálfi István 1627-1667 & adószedő 1636, 1640 \\
\hline Benkő Bálint 1654-1661 & alszolgabíró 1647, nótárius 1651, \\
& $\begin{array}{l}\text { 1656-1659, adószedő 1651, 1659 } \\
\text { körül }\end{array}$ \\
\hline
\end{tabular}

A megyék és a hiteleshelyek között már a középkorban is szoros volt a kapcsolat. ${ }^{228}$ A vármegyék hiteleshelyi tevékenységet is végeztek, a külső hiteleshelyi munkák közül vizsgálatok elvégzésére kaptak megbízást, határjárásokat, iktatásokat csak jelentéktelenebb esetekben végezhettek. ${ }^{229}$ Kolozsmonostoron a középkor utolsó évtizedeiben már előfordult, hogy a hiteleshely írnoka egyben a vármegye jegyzői feladatait is ellátta, ${ }^{230}$ nem előzmények nélküli tehát a két „kancellária” összevonása. Erre részben az adott okot, hogy a hiteleshely és a sedria ugyanabban a városban székelt, részben pedig valószínúleg az, hogy a hiteleshelyi requisitorok a jogi írásbeliségben alapos felkészültséggel rendelkező hivatalnokok voltak, akik egyébként is - hiteleshelyi tevékenységük során - állandó kapcsolatban voltak a vármegyei nemességgel, ismerték az éppen folyamatban levő peres ügyeket, hiszen ők foglalták írásba a perek iratanyagát (is). A

\footnotetext{
${ }^{228}$ Erről bővebben C. Tóth Norbert: Adatok a megyék és a hiteleshelyek közötti viszonyra a 14. és 15. században. In: Századok 136 (2002). 351-364.

${ }^{229}$ A megyék hiteleshelyi működéséről lásd Tringli István: Megyék a középkori Magyarországon. In: Honoris causa. Tanulmányok Engel Pál tiszteletére (szerk. Neumann Tibor és Rácz György). Budapest-Piliscsaba, 2009. 502-504.

${ }^{230}$ A konvent szekularizáció előtti jegyzői közül Szegedi Csomai Benedek fiáról, Miklós deákról és Haczaki Gáspárról tudjuk, hogy egyben vármegyei nótáriusok is voltak lásd KmJkv I. 101-102.
} 
fentebb közölt táblázat alapján megállapítható, hogy az 1560-1624 közötti több mint fél évszázad során vélhetően folyamatosan valamelyik kolozsmonostori levélkereső végezte a vármegyei nótárius feladatait, majd egy hosszabb (szinte harmincévnyi) szünet után a szintén „káptalan” Benkő Bálintot találjuk e funkcióban. Nem tudtuk megállapítani, hogy ez a következetesség miért szakadt meg, talán a levélkeresők „,terheltsége” (a fejedelmi birtokigazgatásban gyakran vették igénybe szolgáltatásaikat) olyannyira megnövekedett, hogy nem tudták e tisztséget is elvállalni, vagy pedig a vármegyei nemesség nem találta őket megfelelőknek.

A vármegyei jegyzők választás útján kerültek hivatalukba, kiválasztásukban a legfőbb szempont a szakértelem, a jogban és a jogi írásbeliségben való jártasság volt. Csaknem mindannyian igen alapos, esetenként átlagon felüli jogi ismeretekkel rendelkeztek. ${ }^{231} \mathrm{~A}$ jegyzők elsődleges feladata a vármegyei protocollumok vezetése és őrzése volt, de ők foglalták írásba a vármegye előtt tett bevallásokat (elsősorban ügyvédvallásokat), és a hatósági parancsra tett jelentéseket is elsősorban ők jegyezték le. A perfolyamattal kapcsolatos teljes ügyintézés is a nótárius hatáskörébe tartozott. Ezeken kívül a jegyző részt kellett, hogy vegyen a cirkáláson, az adószedő mellé segítségül rendelték (abban az esetben, ha nem ő látta el ezt a tisztséget is) és általában a vármegye országgyülési követei között is megtaláljuk. ${ }^{232}$

A levélkeresők ügyintézésben, joggyakorlatban, közigazgatásban szerzett jártassága járulhatott ahhoz, hogy időnként őket alkalmazták a vármegye adóigazgatásánál is. A XVI. század második felében lesz egyre gyakoribb a vármegyénként való adózás és adószedés, és úgy tưnik, hogy e század végétől állandó vármegyei tisztviselővé válik a perceptor, mely hivatal állandósulásának egyik legnagyobb akadályát, a szakirodalom szerint, az azzal járó nagy felelősség képezte. ${ }^{233}$ A perceptorok a közterhek és a katonáskodás alól hivataloskodási idejükre mentességet élveztek, továbbá a vármegyei adóból munkájukért megszabott összeget kaptak. ${ }^{234} \mathrm{~A}$ levélkeresők közül Tordai Péterről tudjuk, hogy Bethlen István javasolta

${ }^{231}$ A tisztségről bővebben Dáné Veronka: „Az ônagysága széki így deliberála”. Torda vármegye fejedelemségkori bírósági gyakorlata. Erdélyi Tudományos Füzetek 259. Debrecen-Kolozsvár, 2006. 62-65. Vö. Fekete Lajos: A vármegyei tisztikar a XVI-XVII. században. Bp., 1914. 82-87.

${ }^{232}$ A kolozsmonostori konvent levélkeresői közül egyedül Szamosközi Mihályról tudjuk, hogy Doboka vármegyei jegyzőként részt vett az országgyülésen. Vö. 409. jegyzet.

${ }^{233}$ Kádár József-Tagányi Károly-Réthy László-Pokoly József: Szolnok-Doboka vármegye monographiája I. Deés, 1901. 375-378.

${ }^{234}$ Szőlősi István requisitor és Kolozs vármegyei adószedő 1617-re szóló elszámolása alapján a perceptor évi fizetése a vármegyei adóból 24 Ft-ot tett ki. Az 1617. május 4-i országgyúlés portánként $8 \mathrm{Ft}$-ot szabott ki, a beszedett összegből a főispánoknak $100 \mathrm{Ft}$, az alispánoknak és szolgabíráknak $32 \mathrm{Ft}$, a kolozsmonostori levélkeresőknek pedig fejenként $25 \mathrm{Ft}$ jutott (KmProt XX. $\left.7^{\mathrm{r}}-77^{\mathrm{v}}\right) .1654$-ben Kraszna megye adójából a perceptor 16 Ft-os fizetése megegyezett a nótárius salariumával lásd, az ENMLt a KvNLt őrizetében, Bánffy lt, nr. 27. (régi fasc. IV. a). 
ezen tisztségre, és az adó beszolgáltatásában jelentkező késedelmek miatt mentették fel hivatala alól. ${ }^{235}$

Végül, mielőtt elkezdenénk a levélkeresők életútjainak bemutatását, ki kell térnünk röviden műveltségi szintjükre és az erdélyi művelődésben betöltött szerepükre. ${ }^{236}$ Néhányan átlagon felüli igényekkel és ehhez mérhető teljesítményekkel rendelkeztek. Szalárdi János - aki a konventben csak rövid ideig szolgált, de korábban a váradi hiteleshelyen is müködött - korszakának legnevesebb krónikása, Pálfi István híres kalligráfus és könyvgyűjtő, Csanádi Pál pedig hosszú ideig a kolozsvári unitárius iskola rektora, majd az unitárius egyház püspöke volt. Ezen három requisitor közül egyedül Pálfiról állíthatjuk biztosan azt, hogy élete végéig „főállású" levélkereső volt, aki a szívén viselte a levéltár és a hiteleshely sorsát, rendezte az okleveleket, mentette a pusztulástól a középkori regisztrumokat. Szalárdi, habár a városhoz vagy a fejedelemhez intézett panaszleveleiből arra következtethetnénk, hogy csak kényszerből, a kis salariumért végezte munkáját, a körülményekhez képest rendszeresen vezette a jegyzőkönyvet, sőt még arra is talált alkalmat, hogy rendezze az összekeveredett iratanyagot és a korábbi protocollumokhoz elenchusokat készítsen. ${ }^{237}$ E néhány példa mellett maga a fennmaradt levéltári anyag mennyisége tanúskodik leginkább amellett, hogy a levélkeresők munkájukat nem csak egyszerü (mellék)keresetnek tekintették, hanem tevékenységükben a múlt emlékei iránti személyes érdeklődés és a felelősségtudat is fontos szerepet játszott. Ennek a hozzáállásnak köszönhető, hogy a konvent középkori és újkori protocollumai, valamint a hiteleshelyi levéltár jelentős része, Erdély történetének páratlan értékű forrásaiként, egyáltalán ránk maradtak.

${ }^{235}$ 1628-ban Bethlen István Kolozs megyéhez intézett levelében írja Tordairól: „,az kegyelmetek vármegyéjének perceptora ki ennek előtte való üdőkben, egynéhány esztendeigh nekem jámbor szolgám lévén ugyan én commendaltam valais arra az állapotra", lásd MOL F25 (Miscellanea), f. 514.

${ }^{236}$ Bővebben lásd a következő fejezet életrajzainál.

${ }^{237} \mathrm{KmProt}$ XVIII. elején. 


\title{
VI. 9. A kolozsmonostori konvent fejedelemség kori levélkeresőinek jegyzéke ${ }^{238}$
}

\author{
János deák (Óvári János) ${ }^{239} 1560$ (1552) - 1575
}

Kolozsvári polgárcsaládból kerülhetett a közeli konventhez jegyzőként, talán már 1545-ben. ${ }^{240}$ Valószínúleg vele azonosíthatjuk azt a János deákot, aki a város számadáskönyveiben 1564-70 között az Óvárban szerepel adófizetőként. ${ }^{241}$ Ezt a feltételezést az is alátámasztja, hogy egy 1586-ban kelt forrásban Owary Jánosnak nevezik. ${ }^{242}$ 1552-ben még a konvent protonotariusa, ebből arra következtethetünk, hogy nem egyedül végezte az oklevél-szerkesztési munkát, több jegyző is dolgozhatott a hiteleshely kancelláriáján. A forrásokban gyakran illetik discretus titulussal, amely talán arra utal, hogy pályája kezdeti szakaszában klerikusként tevékenykedett. ${ }^{243}$ Az ő személyéhez kapcsolható az 1549-1556. évi bevallásokat tartalmazó jegyzőkönyvek utólagos egybekötése a levéltárban hányódó fogalmazványokból. Jakó Zsigmond feltételezése szerint még Fráter György akaratából kezdhette el János deák ezt a munkát, melyet aztán egészen a szekularizációig, de azután is - feltehetően a levélkeresői intézmény végleges megszervezéséig (1575) - folytatott. Ekkor egyedül az ő személye biztosította a folytonosságot az okleveles gyakorlatban. ${ }^{244}$ Az 1560-1573 közötti időszakban adatolhatóan mindig János deák az, aki kolozsvári polgárok társaságában, a fejedelem levélkerestető parancsára kiment Kolozsmonos-

\footnotetext{
${ }^{238} \mathrm{E}$ fejezet korábbi, rövidebb változatát lásd Bogdándi Zsolt: $A$ kolozsmonostori konvent fejedelemség kori levélkeresói. In: Erdélyi Múzeum 2010/3-4. 43-72.

${ }^{239}$ János deákot Sunkó Attila véleményünk szerint tévesen azonosította Csanádi Jánossal, aki csupán névleg viselte ezt a hivatalt, János deák viszont feltehetően az 1575. évi instrukcióig egyszemélyes „konventként” kezelte a kolozsmonostori levéltárat. A két különböző személyre vonatkozó adatokat alaposan összekeverve lásd az „archontológiai" összeállításban, Csanádi János neve alatt: Sunkó: Archontológia 314-315.

${ }^{240} \mathrm{KmJkv}$ I. 88.

${ }^{241}$ Kolozsvár város számadáskönyvei (KvSzám) a KvNLt-ban: 1/IX. 20., 121., 221. 1/XIII 15. 105., 189., 280. (Kiss András adatai alapján, melyeket ezúton is köszönök).

${ }^{242}$ SzT VII. 200: 1586-ban említik a Szegedi György városi jegyző és „owary Janos deak” kolozsmonostori konvent által kiállított regestrumot.

${ }^{243}$ A Magyarországi Középkori Latinság Szótára III. Bp., 1992. 172-173. A discretus szócikknél megadott példák egyháziakra vonatkoznak. János deák discretus címére (zárójelben az említés keltével) lásd MOL DF 255030 (1568); DF 235576 (1569); DF 255036 (1570); DF 255273 (1573). János deák titulusaiban feltűnő és számunkra megmagyarázhatatlan következetlenség figyelhető meg: 1560. április 18-án még nobilis és Kolozs megye jegyzője (DL 74258), ugyanazon év novemberében azonban már providusként (!) vármegyei nótárius (DL 74264, 74175), és ugyanígy szerepel a következő év januárjában (DL 74362), 1563-tól viszont újra nobilisként jelenik meg.

${ }^{244} \mathrm{KmJkv}$ I. 89.
} 
torra, és megkereste az igényelt iratot. ${ }^{245}$ Ennek szövegét vagy a helyszínen rámásolták a parancslevél hátoldalára, vagy magukhoz vették az eredetit és bevitték Kolozsvárra, ahol a bíró nevében kiállított és a város pecsétjével megerősített átiratban lemásolták. Ebből az időszakból néhány olyan jegyzet is megmaradt, melyet János deák a levéltárban megtalált levelekről készített. ${ }^{246}$

Az 1563 júniusában tartott országgyülés már ezt a gyakorlatot próbálta törvényesíteni azzal, hogy a konventi jegyző János deák, akkor már Kolozs vármegyei nótárius requisitorként való felesketését rendelte el, javadalmazását pedig az átírásért fizetendő illetékekkel kívánta megoldani. ${ }^{247} \mathrm{~A}$ hiteleshelyi tevékenység beszűkülése a konventi levéltárban őrzött iratok lemásolására természetesen jelentősen csökkentette a nótárius jövedelmeit, aki addig minden egyes oklevél kiállításának díjából egy bizonyos részt kapott. Bizonyára ez is, de valószínúleg rátermettsége is nagymértékben hozzájárulhatott ahhoz, hogy János deákot Kolozs vármegye jegyzőjévé választotta, és ezt a hivatalt bizonyíthatóan 1570-ben is viselte. ${ }^{248} \mathrm{~A}$ következő év novemberében a rendek viszont már arra kérték a fejedelmet, hogy új embereket, Tolnai Miklós deákot, Csanádi Jánost és a városi jegyző Miklós deákot nevezze ki a kolozsmonostori levéltárhoz. ${ }^{249} \mathrm{Az}$ új levélkeresők kijelöléséhez feltehetően az járulhatott hozzá, hogy János deák oklevél-hamisítás gyanújába keveredett, és emiatt fogságra is vetették. ${ }^{250}$ 1573-ban azonban az országgyülésen ismét szóba került a kolozsmonostori hiteleshely múködésének az ügye, János deák pedig újból ,juratus notarius Abbacie de Colosmonostra"-ként tűnik fel, tehát megint ő az, aki a konventi levéltárból az okleveleket megkeresi. ${ }^{251}$ Noha még 1580-ban is életben lehetett, a hiteleshely működésében már nem volt szerepe.

János deák képzettségéről semmi közelebbit nem sikerült megállapítani, lendületes, könnyed írása azonban alapos gyakorlatról tanúskodik. Történeti érdeklődésének bizonyságai egyetlen fennmaradt könyvében tett bejegyzései kora jelentősebb eseményeiről. ${ }^{252}$

${ }^{245}$ 1560: DL 28003; 1561: DL 74362; 1563: DL 36957; 1569: DF 253576; 1573: DF 255273.

${ }^{246}$ MOL F25. (Miscellanea, 1560 körül kelt számozatlan lapokon): „Memoriale super requisitis litteris pro domino Joanne Kendy de Zenthywan consignate" (az oklevelek rövid kivonatai, Joannes notarius aláírással).

${ }^{247}$ EOE II. 218-219.

${ }^{248}$ 1560-tól jelenik meg vármegyei jegyzőként lásd DL 74258 (1560); DF 255036 (1570).

${ }^{249}$ EOE II. 506.

${ }^{250}$ MOL R 314, Városi iratgyüjtemény, 10. doboz, Vegyes iratok, 2a csomag, f. 25 $5^{\text {rvv }}$. (Az adatért Pakó Lászlónak tartozom köszönettel).

${ }^{251}$ DF 255273.

${ }^{252}$ Ez egy Eber-féle Calendarium historicum az 1551. évre, melyet János deák a címlapon olvasható bejegyzése szerint 1553-ban vásárolt: „Sum Joannis literati notarii de Colosmonostra 1553." Az utolsó bejegyzés 1580-ból való. Paul Eber kalendáriumainak történeti forrásérté- 


\section{Csanádi János deák}

A hiteleshely történetében csupán epizódszerepet játszott. 1571-ben a rendek őt is requisitornak javasolták, ${ }^{253}$ feltehetően János deák említett oklevél-hamisítási ügye miatt, de levélkeresőként bizonyára soha nem tevékenykedett. Csanádi 1558-1569 között a nagyobb kancellária írnoka, majd 1567-ben, illetve 1569-ben kancelláriai titkárként jelenik meg a forrásokban. ${ }^{254}$ Igazi hivatalnok-értelmiségi karrier az övé, amely azonban tragikus módon végződik: 1575-ben, Bekes többi hívével együtt lefejezték. ${ }^{255}$

\section{Tolnai Miklós deák}

Csakúgy, mint Csanádi, Tolnai Miklós is csak a rendek javaslatában szerepel kolozsmonostori levélkeresőként, tényleges működésének semmi nyoma. Ő is a nagyobb kancelláriáról került (volna) a hiteleshelyhez, írnokként 1559-1570 között említik. ${ }^{256}$

\section{Zalánkeményi Miklós deák 1575-1576}

Az 1571-ben kinevezettek közül valószínűleg ő az egyedüli, aki - bár rövid ideig - de valóban requisitorként müködött a konventi levéltárnál. Igazi deák-értelmiségi családból származott, vajdai protonotarius apját az a népmozgalom sodorhatta Erdélybe, amely tömegeket kényszerített távozásra a törökök által veszélyeztetett déli határvidékről az ország védettebb tájaira. ${ }^{257} \mathrm{~A}$ család a fejedelemség legjelentősebb városában, Kolozsváron telepedett meg, Zalánkeményi Albert ítélőmester itt szerzett örökséget, leányai helybéli polgárokkal házasodtak, fiai közül pedig a már 1571-ben requisitornak javasolt Miklós városi jegyző lett. ${ }^{258}$ Miklós deák bizonyára csak az 1575-ös instrukció kelte után, az év végétől haláláig teljesített

kéről és János deák bejegyzéseiről lásd C. Feneşan-K.G. Gündisch: Informații privind istoria Transilvaniei (sec. XVI-XVII) in calendarele lui Paul Eber. In: Anuarul Institutului de Istorie Cluj XVII/1974. 81.

${ }^{253}$ EOE II. 506.

${ }^{254}$ Trócsányi: Központi kormányzat 185.; Berger Albert-Wagner Ernst: Urkundenregesten aus dem Archiv der Stadt Bistritz in Siebenbürgen. II. Köln-Wien, 1986. 3137. sz.

${ }^{255}$ Bethlen Farkas: Erdély története. III. Budapest-Kolozsvár, 2004. 86.

${ }^{256}$ Trócsányi: Központi kormányzat 196.

${ }^{257}$ Zalánkeményi Albert protonotariusról bővebben lásd Jakó Zsigmond: Az erdélyi vajda kancelláriájának szervezete a XVI. század elején. In: Erdélyi Múzeum LII (1947). 75-76.

${ }^{258}$ Zalánkeményi Miklós 1569-1576 novembere között viselhette a városi jegyzői tisztséget, lásd Binder 1982. 230.; Kiss: Más források 192.: „Nicolaus Zalonkemeny notarius huius civitatis septennio vel circiter huic senatui non minus fidelem que utilem cum praestitisset opera tandem in ipso officio supremum vitae obiit anno 1576 mense Novembris." 
a konventnél levélkeresői szolgálatot, és ugyanakkor a városi nótárius feladatait is ellátta. Ismereteink szerint ez az egyedüli fejedelemség kori példa a városi és a hiteleshelyi jegyzőség összevonására, Rákosi Péter a következő, akiről sikerült megállapítani, hogy mindkét tisztséget egyszerre töltötte be, de ő már a fejedelemség korának végén tevékenykedett.

Zalánkeményi Miklós családjáról és vagyoni helyzetéről egy 1590-ben kelt osztálylevélből értesülünk. ${ }^{259}$ Ekkor néhai Zalánkeményi Albert erdélyi ítélómester fiának, a kolozsmonostori levélkereső néhai Miklós deáknak egy azonos nevű fiát és egy Erzsébet nevú leányát említik, akik megosztoznak ugyanazon Albert fiával, a váradi káptalan requisitorával, Jánossal, valamint Albert másik fiának, néhai Bálintnak leányával a kolozsvári jószágokon, egy Közép utcai kőházon és a város határában levő földeken. Ezek szerint Albert ítélőmester három fia közül kettő értelmiségi pályán érvényesült, a kolozsmonostori hiteleshelyen Miklós, a váradin pedig János teljesített szolgálatot. Ez utóbbi talán azonos azzal a Zalánkeményi Jánossal, aki 1583-ban Bolognában diákoskodott. ${ }^{260}$ Úgy tűnik, hogy a fejedelemség területén múködő hiteleshelyek közötti kapcsolatot időnként rokoni szálak is erôsítették. A Zalánkeményi testvérpár mellett erre utalhat a két Balásfi testvér kolozsmonostori, illetve gyulafehérvári hivatalviselése. Már Trócsányi felhívta a figyelmet arra, hogy a hivatalnokrétegnek volt egy olyan része, melynek alapvető életformája századokon át a hivatalnokoskodás maradt, ők értelmiségi "dinasztiákat” alkottak, melyeket egymáshoz szoros rokoni kapcsolatok füztek. ${ }^{261}$ Zalánkeményi Miklós özvegyét 1576 novemberében bekövetkezett halála után szintén egy litteratus, a gyulafehérvári káptalani levélkereső, Lippai Péter vette el. Arván maradt gyermekei vele kötöttek egyezséget 1594-ben, az őket Kolozsváron megillető anyai jószágaikról. ${ }^{262}$

Zalánkeményi Miklós requisitor azonos nevü fia talán szintén értelmiségi pályára lépett. A források 1594-ben említik, amikor Báthory András bíboros famulusaként éppen Lengyelországba utazott, Magyarrődön levő apai birtokrészeinek kezelésével pedig a konvent egyik levélkeresőjét - talán rokonát -, Kolozsvári Márton deákot bízta meg. ${ }^{263}$

\footnotetext{
${ }^{259} \mathrm{KmProt}$ X. $429^{\mathrm{r}}-429^{\mathrm{v}}$.

${ }^{260}$ Szabó-Tonk: Egyetemjárás 103. (1073. sz.)

${ }^{261}$ Trócsányi: Központi kormányzat 412-413.

${ }^{262} \mathrm{KmProt} X .272^{\mathrm{r}}-272^{\mathrm{v}}$. Az egyezségből az is kiderül, hogy Zalánkeményi Miklóstól gyermekei egy Farkas utcai házat is örököltek.

${ }^{263} \mathrm{KmProt}$ X. $298^{\mathrm{r}}-298^{\mathrm{v}}$.
} 


\section{Somogyi Bálint ${ }^{264} 1575$}

Bálint papról annyira bizonytalan adatokkal rendelkezünk, hogy még családnevét sem sikerült pontosan megállapítani. Az 1575 júliusában tartott országgyưlés nevezte ki a kolozsmonostori konventi hiteleshely élére „Polyáni Bálint pap”-ot. ${ }^{265}$ De ugyanabban az évben, az egyik középkori bejegyzéseket tartalmazó protocollum borítóhártyáján „conservator Valentinus presbiter de Somogy"-ként szerepelt. ${ }^{266}$ A legvalószínűbb az, hogy a magyarországi Somogyról Erdélybe került protestáns lelkésszel van dolgunk, akit talán azonosíthatunk azzal a Polyáni Bálinttal, aki 1566-ban nagyalmási prédikátor és kalotaszegi senior volt ${ }^{267}$ requisitori kinevezése előtt pedig Aranyospolyánon szolgálhatott mint lelkipásztor. Úgy tünik tehát, hogy a kezdetekben, 1575 után néhány évig mindhárom szekularizált hiteleshelyen klerikusok felügyelete alatt folyt az oklevéladó tevékenység. Talán ezzel próbáltak a fejedelem és a rendek szorosabb felügyeletet és nagyobb hitelt biztosítani müködésüknek. ${ }^{268}$ Somogyi Bálint 1577-ig vagy 1579-ig teljesített szolgálatot a hiteleshelyen, utóbb a conservatori címet már Kolozsvári Márton viselte, a másik két levélkereső pedig Szentiványi György (1577-től) és Balásfi Ambrus (1579-től).

\section{Kolozsvári Márton deák 1575-1600}

Márton deák Kolozs vármegyei jegyzőként került 1575-ben a konventhez, mely hivatalát még 1593-ban is viselte. ${ }^{269}$ Valószínúleg 1600 első felében bekövetkezett haláláig szolgált a kolozsmonostori konventnél, 1594-től

\footnotetext{
${ }^{264}$ Sunkónál tévesen Polgári Mihályként szerepel lásd Sunkó: Archontológia 318. Ezzel a névváltozattal még Jakab Eleknél találkozunk, lásd Jakab: Erdély egyháztörténelméhez 9. Jakab tévedésének forrása bizonyára Kemény József lehetett, nála viszont Polgári Bálintnak hívják a requisitort, vö. Kemény: Notitia 43. A Kemény által is idézett forrásban azonban biztosan Polyáni Bálint pap szerepelt, lásd EOE II. 562-563.

${ }^{265}$ EOE II. 562-563.

${ }^{266}$ KmJkv II. 4319. sz.

${ }^{267}$ Tüdős S. Kinga: Erdélyi testamentumok II. Erdélyi nemesek és föemberek végrendeletei. Marosvásárhely, 2005. 76.

${ }^{268}$ Gyulafehérváron Ilosvai Benedek pap (EOE II. 562-563), Váradon pedig Kristóf presbiter (ErdKirKv VII. 3. 63. sz.) irányította a hiteleshelyet.

${ }^{269}$ SzT III. 218. 1579-ben feltehetően a vármegyei adó beszedését is ő felügyelte perceptorként, lásd Beke: A kolozsmonostori konvent 490. sz. (Márton deák a regesztában kolozsvári nótáriusként szerepel, de ez valószínűleg Beke tévedése, Kolozsvári Márton ekkor vármegyei jegyző volt.); 1585-ből és 1587-ből fennmaradt cegei Wass György Kolozs vármegyei ispán és Márton deák vármegyei jegyzo „hivatali” levelezésének két darabja, melyek értékes adalékokkal szolgálnak a vármegyei adminisztráció működésére vonatkozóan, lásd MOL F25 (Miscellanea), 230, 254 f. 1593-ban is vármegyei jegyzőként jelenik meg, lásd KmProt X. 296r.
} 
bizonyíthatóan conservatorként, tehát a hiteleshely vezetőjeként. ${ }^{270}$ Kolozsvárról került a vármegye, illetve a hiteleshely kancelláriájához, 1577-ben mint köztiszteletnek örvendő, vagyonos polgár már a város centumvirei között szerepel. Bizonyára a gyakorlati jogban való alapos jártasságának, szakértelmének köszönhetően kerülhetett 1593-ban a fejedelmi tábla ülnökei közé, ahova - országgyülési határozat értelmében - csak olyanokat választottak, „,az kik tudósok deáki tudománban és az törvínben”. ${ }^{271}$ Márton deák számára azonban ez még nem jelentette hivatalnoki karrierjének csúcsát, 1597-től ugyanis már ítélőmesterként jelenik meg a forrásokban. ${ }^{272}$ Mindezen hivatalai mellett feltehetően haláláig a konvent vezetője maradt, sőt időnként az ország pénzügyeinek igazgatásában is szerepet vállalt, 1594-1599 között többször is adószámvevőként találkozunk nevével. ${ }^{273}$ Még azt is valószínúsíthetjük, hogy ő lehetett az a Márton deák, akit Báthory Zsigmond többször menesztett követként Konstantinápolyba vagy Prágába. ${ }^{274}$ Ennyi hivatali teendő mellett csupán időnként tartózkodhatott szülővárosában, ezért a hiteleshelyi feladatok végzése is bizonyára egyre inkább kollégáira hárult.

Adatok hiányában nehéz képet alkotni arról, hogy milyen családi háttér tette lehetővé ezt a magasra ívelő hivatalnokkarriert. Talán családi öröksége volt az a sütőház, melyet az Óvárban birtokolt, de az is lehet, hogy Bek Katalin nevü felesége jussán jutott kezéhez. ${ }^{275}$ Családjától maradt kolozsvári jószágai mellé - hivatali szolgálatai jutalmaként - úgy tünik, nem sokat szerzett: a Kolozs megyei Magyar- és Oláhrődön kapott adományba egy birtokrészt, de azt is egyezkedések árán vehette birtokba, ${ }^{276}$ továbbá

\footnotetext{
${ }^{270}$ Habár csak 1594-1595-ben nevezik conservatornak, feltehetően haláláig ő felügyelte requisitortársai munkáját. Conservatori címére lásd KmProt X. 298 $-298^{\mathrm{v}}, 377^{\mathrm{v}}$.

${ }^{271} 1578$ áprilisában hozott határozat: EOE III. 133.

272 1593-1596: ítélőszéki ülnök és requisitor (KmProt X. 269r , KmProt X. 473v); 1597-1598: ítélőmester és requisitor (KmProt X. 369). Vö. Trócsányi: Központi kormányzat 357.

${ }^{273}$ Trócsányi: Központi kormányzat 316.; Az 1598-ban tartott fehérvári országgyülés elhatározta, hogy „Az minémű adóbeli restantiák penig, úgymint két-ezer nyolczszáz kilenczvennégy forint nyolczvannégy pénz, Theke Ferencz uram idejébe beszedetlen maradtanak, arról tetszött, hogy azt ez jövendő bőth közép szeredára minden vármegyékből az ispánok, viceispánok, királybírák és perceptorok kétszáz forint tereh alatt Kolosvárra Márton mester kezébe szolgáltassák" (EOE. IV. 131.)

${ }^{274}$ EOE IV. 10., 14-15.

2751592-1595 között szerepel az Óvárban adófizetőként, lásd KvSzám 5/XV. 20., 5/XVI. 22., 5/XVI. 86., 5/XVI. 150. (Az adatokért Kiss Andrásnak tartozom köszönettel.)

${ }^{276} \mathrm{Az}$ 1597-ben kötött egyezség szerint magyarrődi Cseh, másként Dezső Péter és Miklós 50 Ft-ért lemondtak Márton deák ítélőmester és requisitor javára saját magyar- és oláhrődi jószágaikról, melyeket az hűséges szolgálataiért nyert el. Cselekedetüket azzal indokolták, hogy Márton deák ítélőmesterként segítheti őket pereikben: „volentes etiam animum dicti Martini litterati erga sese demerere... cuius ope et auxilio ipsi in prosecutionibus caussarum suarum plurimum indigerent" (KmProt X. 369r-370 $)$.
} 
egy bósi jobbágyáról van tudomásunk. ${ }^{277}$ Kolozs vármegye szintjén tehát mindenképpen kisbirtokosnak számított. Érdekes módon az említett Rődön Márton deák birtokostársai a Zalánkeményiek és a gyulafehérvári levélkereső, Lippai Péter voltak, talán a fejedelmek fenntartottak hivatalnokaik számára egy-egy birtokrészt, ezzel jutalmazva szolgálataikat. ${ }^{278}$

Kolozsvári Márton egyszerű városi polgárként országos főtisztségre jutott. Pályája valamikor az 1599 második fele, 1600 eleje közötti időszakban érhetett véget. Ô az egyedüli levélkereső, akinek síremléke is fennmaradt, a Farkas utcai templom 1911. évi restaurálásakor került elő az egyház padozatkövei közül. ${ }^{279}$ Temetésekor a Farkas utcai épületegyüttes a jezsuiták birtoka, ez egyértelműen bizonyítja, hogy Márton deák katolikus volt. Szaktudása mellett bizonyára ez is hozzájárulhatott karrierje sikeréhez.

A kolozsvári szász patríciuscsaládból származó feleségétől, Bek Katalintól feltehetően két fia született: az egyiket, Mártont sírköve említi (róla nevén kívül semmit sem tudunk), János nevü fia viszont valószínüleg apja nyomdokaiba lépett, talán ő az a kincstári jogügyigazgató, aki 1603-tól viselte ezt a tisztséget. ${ }^{280}$

\section{Szentiványi György (Kolozsvári György deák) 1577-1613}

Annak ellenére, hogy nagyon hosszú időn keresztül teljesített levélkeresői szolgálatot, György deák életútjáról csupán hézagos adatokkal rendelkezünk. Lakatgyártó apja talán valamelyik erdélyi Szentivánról került János Zsigmond gyulafehérvári udvarába, majd onnan Kolozsvárra. ${ }^{281}$ Ügyes mesteremberként hamarosan akkora vagyonra tehetett szert, hogy fiát, a későbbi requisitort a városi iskolában taníttathatta, de az sem kizárt, hogy wittenbergi tanulmányait is finanszírozta. Ez a feltételezés akkor bizonyosodhat be, ha egyértelmüen kiderül, hogy Szentiványi György azonosítható azzal a „Georgius Serarii Claudiopolitanus"-szal, aki 1567-ben a wittenbergi universitason tanult. ${ }^{282} \mathrm{Az}$ a Kolozsvári György viszont, aki 1569-ben alumnusként írt levelet Wittenbergből szülővárosába - a kézírás alapján - nem valószínü, hogy vele azonos. ${ }^{283} \mathrm{Az}$ is kérdés, hogy Szent-

\footnotetext{
${ }^{277}$ MOL F25 (Miscellanea), $283 \mathrm{f}$.

${ }^{278}$ A Zalánkeményiek birtoklására lásd KmProt X. 298 $-298^{v}$, 473루 ; Lippai Péter birtoklására lásd KmProt XVI. 99.

${ }^{279} \mathrm{~A}$ töredékes síremlék szövegét téves keltezéssel és félreértelmezett címmel közölte Sándor Imre: A kolozsvári Farkas-utczai ref. templom régi sírkövei. Kolozsvár, 1913. 17. A sírkő jelenleg a Kolozsvári Történeti Múzeum kapualjában található (Mihály Melinda szíves közlése). Vö. Balogh Jolán: Kolozsvári kőfaragó múhelyek. XVI. század. Bp., 1985. 191-192.

${ }^{280}$ Trócsányi: Központi kormányzat 364.

${ }^{281}$ Sunkó: Archontológia 321.

${ }^{282}$ Szabó-Tonk: Egyetemjárás 67. (660. sz. alatt).

${ }^{283}$ MOL F25 (Miscellanea), 135 $-135^{\mathrm{v}}$.
} 
iványival azonosítható-e a fejedelmi kisebb kancellárián 1568-ban, majd 1579-ben szolgáló Kolozsvári György deákok közül valamelyik. ${ }^{284} \mathrm{Az} 1598$ elött fejedelmi secretarius Szentiványi Gábor deák talán rokona lehetett. ${ }^{285}$

Szentiványi Györgyöt 1577-ben már a konventnél találjuk, és hivatali karrierje el is akadt ezen a szinten. Hosszú ideig tartó levéltárosi szolgálata alatt arra is volt gondja, hogy két protocollum-kötetet mutatóval lásson el. ${ }^{286}$ Azon levélkeresők között tarthatjuk számon, akik szívükön viselték a gondjukra bízott levelek sorsát. Erre az is utal, hogy levelezőpartnere volt a neves humanista, Szamosközi István gyulafehérvári káptalani levélkereső, aki történetíróként felismerte a hiteleshelyi levéltárakban őrzött levelek forrásértékét, jelentőségükre a rendek figyelmét is megpróbálta felhívni. ${ }^{287}$

Szentiványi György hivatali pályája során csupán annyit ért el - talán kapcsolatai, állása révén -, hogy Kolozsváron levő családi vagyonát tovább gyarapította, de vármegyei birtokszerzéseiről nem tudunk. György deáknak bizonyára nem sikerült a város keretei közül kitörni, feltehetően élete végéig birtoktalan nemes polgár maradt. Tekintélyes vagyona viszont lehetővé tette számára különböző kölcsönügyletek lebonyolítását, így sikerült - említett Monostor utcai ingatlana mellé - zálog címén megszereznie néhai Borbély Ferenc főtéri házának egy részét és egy Széna utcai házrészt. ${ }^{288}$

György deák nevével requisitorként utoljára 1613-ban találkozunk, amikor egy bizonyos összeget helyeztek letétbe nála. ${ }^{289} \mathrm{~A}$ halál is ekkor érhette utol, mert a későbbi forrásokból neve nem tűnik elő.

\section{Balásfi Ambrus 1577-1591}

Igazi kolozsvári értelmiségi dinasztia kevéssé ismert tagja, melynek legnevesebbjei testvére, az unitárius hitszónok, Basilius István, illetve unokaöccse, a hitvitázó katolikus főpap, Balásfi Tamás. ${ }^{290}$ Egyik testvérének fia, Balásfi János szintén sikeres hivatali karriert futott be, előbb a kisebb

\footnotetext{
${ }^{284}$ Trócsányi: Központi kormányzat 368., 370.

${ }^{285} \mathrm{KmProt}$ X. 421v.

${ }^{286} \mathrm{KmProt}$ III. és IV. mutatói. Erről lásd KmJkv I. 144. A jegyzőkönyvek leírása uo. 158.

${ }^{287}$ Szamosközi levelének címzése: „Ez levél adassék Coloswarat György deák uramnak, az conventnek, Monostor ucában, bizodalmas uramnak." MOL F25 (Miscellanea), 344-347. Közlése: Erdélyország történetei tára, egykorú s magyar nyelven készített történetiratok-, levelek, országgyülési végzések- és törvényczikkelyekből II. 1845. (közzéteszi Kemény József és nagyajtai Kovács István). 124-126.

${ }^{288}$ Kolozsvári házai, házrészei: KmProt X. $66^{\mathrm{r}}, 265^{\mathrm{v}}-266^{\mathrm{r}}$, 454 ${ }^{\mathrm{r}}-454^{\mathrm{v}}$. Atyai kőháza és telke a Széna utcában, lásd Sunkó: Archontológia 321.

${ }^{289} \mathrm{Az}$ 1614-ben kelt oklevél egy évvel korábbi ügyletre vonatkozik, vö. KmProt XVI. 135r.

${ }^{290}$ A családról bővebben lásd Bogdándi: Balásfiak 807-812.
} 
és nagyobb kancellárián és a gyulafehérvári káptalani hiteleshelynél írnokoskodott, majd 1594-től a fejedelmi kancellária titkára lett. A család tagjai közül tehát egyszerre ketten is szolgáltak a hiteleshelyi levéltárakban.

Ambrus deák először 1577-ben szerepelt kolozsmonostori levélkeresőként. ${ }^{291}$ Kolozsvári háza, melyben hivatalviselése idején feltehetően a konventi levéltár egy részét is kezelte, a Széna utcában, az említett Balásfi János és szülei sarokházának szomszédságában volt. ${ }^{292}$ 1591-ben szerepel utoljára levélkeresőként. ${ }^{293}$ 1593-ban már a Kolozs vármegyei adó számvevője (exactor censuum comitatus Colosiensis), azonban neve mellett requisitori címe nem szerepel, habár - mint tudjuk - gyakran megtörtént, hogy az egyik levélkereső vármegyei adószedő is volt.

\section{Kövendi Mátyás 1593-1614}

Neve alapján ítélve családja a közeli Aranyosszékről kerülhetett Kolozsvárra. 1593-tól szerepel a forrásokban a kolozsmonostori requisitorok sorában, az akkoriban elhunyt Balásfi Ambrust válthatta fel hivatalában. ${ }^{294}$ Semmit nem tudunk arról, hogy milyen családi és társadalmi háttér segítette elő Mátyás deák városi hivatali emelkedését, bizonyára alapos jogi felkészültségének, szakértelmének köszönhetően került 1603-ban a kolozsvári directorok közé. ${ }^{295}$ Ekkor már a város köztiszteletben álló, vagyonos polgára lehetett, hiszen neve a százférfiak sorában is szerepel. ${ }^{296}$ Halála 1614 júniusában következett be. ${ }^{297}$

\section{Kibédi János 1601-1602}

A marosszéki székely származású Kibédi János a fejedelmi kisebb kancelláriáról került a konventi hiteleshely levéltárához. ${ }^{298}$ Az ítélőszéknél, az ítélőmesterek szolgálatában sajátíthatta el azt a tudást, melyet utóbb requisitorként kamatoztathatott. 1599-ben Kolozsvárott találjuk, ekkor az

\footnotetext{
${ }^{291}$ KvNLt, Függőpecsétes oklevelek gyưjiteménye (Colecția de documente cu peceți atârnate), nr. 127.

${ }^{292} \mathrm{KmProt}$ VII. $60^{\mathrm{r}}-61^{\mathrm{r}}$.

${ }^{293} \mathrm{KmProt}$ X. $52^{\mathrm{r}}$.

${ }^{294}$ Levélkeresőként való említései időrendben 1593: MOL F25 (Miscellanea), 279r; 1594: „Mattyas deiakot az konventet vyzi Molnar Gaspar 2 lovan zekeren, Pettribe Bogatty zamara ikttattni" (SzT V. 531.); 1596: SzT II. 275.; 1599/1606: SzT VII. 200.; 1609: MOL F25 (Miscellanea), 357'; 1612: KmProt XVI. 91'; 1614: Beke: A kolozsmonostori konvent 533. sz.

${ }^{295}$ Herepei: Adattár III. 563.; Kolozsvári emlékírók 101.

${ }^{296}$ Binder 1982. 290., 293.

${ }^{297} \mathrm{KvNLt}$, Kolozsvár város levéltára, Tanácsi jegyzőkönyvek 6. köt. 167.

${ }^{298}$ A kisebb kancellária íródeákja 1589-1599 között, lásd Trócsányi: Központi kormányzat 368.
} 
Erdélyből távozó Kakas István hű embereként őrá bízza a városban levő háza őrzését. ${ }^{299}$ 1601-ben már a konvent egyik levélkeresője, de tisztségét viszonylag rövid ideig viselte, ${ }^{300}$ valószínúleg a századfordulót követő harcok vagy pestisjárvány áldozata lett. 1602-ben bekövetkezett halála után ingóságain székelyföldi rokonai osztoztak, az értéktárgyak átvételét bizonyító oklevélből derült ki, hogy Kibédi is viselte a vármegyei jegyzői tisztséget. ${ }^{301}$ Helyére talán Hajósi Pál került, aki 1603-tól volt bizonyíthatóan requisitor. ${ }^{302}$

\section{Hajósi Pál 1603-1605}

Családja a Kolozsvárhoz közeli Magyar- és Oláhpatán birtokolt, itt láthatta meg a napvilágot Bornemisza, másként Hajósi Benedek fiaként. ${ }^{303} \mathrm{~Eb}$ ből a kisnemesi környezetből került Hajósi Pál előbb írnokként a fejedelmi kisebb kancelláriára, ahol 1588-1599 között szolgált, ahonnan, feltehetően 1603-tól a konventi hiteleshelyhez távozott. ${ }^{304}$ Szintén e tájban választhatta meg Kolozs vármegye nótáriusának, mely tisztségben haláláig megmaradt. ${ }^{305}$ Bizonyára a századfordulót és az azt követő éveket jellemző kö-

${ }^{299}$ Dr. Veress Endre: Zalánkeményi Kakas István. Magyar Történelmi Életrajzok (szerk. Dézsi Lajos). Bp., 1905. 112.

${ }^{300}$ Requisitorként való említései, időrendi sorrendben 1601: KmProt XV. 45r, 49vi 1602: ENMLt, Bánffy lt, fasc. nr. 25.; 1608-ban néhai: KmProt XIII. 133r.

${ }^{301} \mathrm{KmProt}$ XV. $218^{\mathrm{r}}-218^{\mathrm{v}}, 222^{\mathrm{r}}$.

${ }^{302}$ Ezt a feltételezést az támasztja alá, hogy ebben az időszakban Szentiványi György és Kövendi Mátyás hosszú ideig (1613-ig, illetőleg 1614-ig) viselte requisitori tisztét, mellettük lehetett a harmadik konventi tisztviselő, Kibédi János, majd az őt felváltó Hajósi Pál.

${ }^{303}$ KmProt XVI. 8v.

${ }^{304}$ A kisebb kancellária írnoka, lásd KvNLt, Wesselényi 1t, Documente medievale nr. 150.; Trócsányi: Központi kormányzat 367. Requisitori említései 1603: Basta György hadvezér levelezése és iratai II. (1602-1607). A Magyar Tud. Akadémia Történelmi Bizottsága megbízásából hazai és külföldi levéltárakban gyüjtötte és közrebocsátja Veress Endre. Bp., 1913. 180., KmProt XV. 232v; 1604: Jezsuita Okmánytár I/1. Erdélyt és Magyarországot érintő iratok 1601-1606. Sajtó alá rendezte Balázs Mihály, Kruppa Tamás, Lázár István Dávid, Lukács László. Szeged, 1995. 294.

${ }^{305}$ Halála 1605. október 5. előtt következhetett be. Erre utal Tordai Imre Kolozs vármegyei nótárius ekkor kelt bejegyzése a vármegye jegyzőkönyvében (ENMLt-ban): „Postquam Paulus Haiosy morbo gravissimo ac diuturnissimo oppressus fuisset, tandemque sublatus e vivis et in locum eiusdem per electionem dominorum nobilium in officio notariatus [...] successissem." KolJkv f. 35. Ennek ellentmond viszont a kolozsmonostori protocollumban levő bejegyzés, mely 1606 márciusában még élőként tünteti fel, lásd KmProt XVI. 130v. Talán ez utóbbi oklevél jegyzőkönyvbe való bevezetésekor tévesztette el a dátumot valamelyik levélkereső. (A Kolozs vármegyei jegyzőkönyvekben található adatokra Dáné Veronka hívta fel figyelmemet, segítségét köszönöm.) 
rülmények kényszeríthették rá arra, hogy megélhetéséért időnként kölcsönökhöz folyamodjon, melyek törlesztése halála után rokonaira hárult. ${ }^{306}$

\section{Tordai Imre 1608-1619}

A közeli Tordáról jött Kolozsvárra, ahol először a Kolozs vármegyei jegyzőséget (1605-től), majd 1608-tól bizonyíthatóan a konventi levélkeresői tiszséget is viselii ${ }^{307}$ Családjáról csak annyit tudunk, amennyi 1609-ben kelt, részlegesen közölt címeresleveléből kiderül: feleségét Balogh Annának, leányait pedig Borbálának és Annának hívták. ${ }^{308}$ Ugyanebben az évben már Kolozs vármegye perceptora volt. ${ }^{309}$ Feltehetően hivatali szolgálatai jutalmául nemesítették meg, de arról, hogy nemesként voltak-e birtokai, vagy hogy szolgálata révén miként gyarapíthatta vagyonát, semmit nem tudunk. 1611-ben elvállalta a Kolozs vármegyei adószámvevőséget, de a városban is elismertségre és vagyonra tehetett szert, mert 1608-ban már a százférfiak között szerepel. ${ }^{310} 1613$-ban, majd 1616-ban a város egyik számvevője ${ }^{311}, 1618$ legelején pedig - városi jegyző hiányában - rövid ideig ő vezeti a tanácsi jegyzőkönyvet. ${ }^{312} 1619-1622$ között a fejedelmek által a városnak adományozott quarta gondviselője. ${ }^{313}$ Utoljára 1622-ben találkoztunk nevével, ekkor még Kolozs vármegye jegyzőjeként állított ki egy levelet, ${ }^{314}$ de az is lehetséges, hogy a konventi kancellárián is tevékenykedett még, talán e tájban bekövetkezett haláláig. A vármegyei jegyzői hivatalban bizonyára requisitor-társa, a korábban megyei adófizetói tisztséget is viselő Szőlősi István váltotta fel.

\footnotetext{
${ }^{306} 100$ Ft-ot kölcsönzött kolozsvári Gellyén Imrétől (KmProt XVI. 130v). 1607. május 18-án már testvére, Hajósi István törlesztette néhai testvérbátyjának Filstich Péterrel szembeni tartozását, $50 \mathrm{Ft}$-ot és egy köböl búzát (KmProt XVI. 8v-9r).

${ }^{307}$ Levélkeresőként említik 1608: KmProt XVII. 10; 1614: Beke: A kolozsmonostori konvent 533. sz.; 1616: KmProt XVII. 143r; 1619: KmProt XVIII. 75

${ }^{308}$ Sándor Imre közölte a Báthory Gábor által adott oklevél rövid regesztáját, illetve a címerleírás szövegét és a címerképet. Lásd Czímerlevelek. Gyüjtötte Sándor Imre. II. füzet, Kolozsvár, 1910. 39.

${ }^{309}$ A kolozsmonostori konvent 1t, Batthyaneum LXXVIII/97. sz.

${ }^{310}$ KvNLt, Kolozsvár város levéltára, Tanácsi jegyzőkönyvek 6. köt., 58.; Binder 1982. 295.

${ }^{311}$ KvNLt, Kolozsvár város levéltára, Tanácsi jegyzőkönyvek 6. köt., 164., 224.

312 „Praemissa decreta [...] dominorum centumpatrorum pro anni 1618. huc usque scribebat Emericus Thorday." Uo. 254.

${ }^{313}$ Uo. 277., 300., 362.

${ }^{314}$ ENMLt, Kemény cs csombordi lt, nr. 512.
} 


\section{Bibarcfalvi (másként Simon Literáti) János 1615?}

Sunkó Attila jegyzékében szerepel requisitorként 1615-ben. Mi semmi más nyomát nem találtuk müködésének. A rá vonatkozó életrajzi adatok közlését, minthogy levélkeresői tevékenységét bizonytalannak tekintjük, mellőzzük. ${ }^{315}$

\section{Szőlősi István 1616-1623}

Származásáról, tanulmányairól semmit nem tudunk. Talán polgárként vagy armálisos nemesként kerülhetett előbb a fejedelmi kisebb kancelláriára (1607), 1610-től pedig négy éven keresztül a nagyobb kancellárián szolgált mint íródeák. ${ }^{316} \mathrm{~A}$ kancellárián Angyalos Jánossal alakult ki szorosabb, baráti kapcsolata, erre vall az a tény, hogy hozzá intézett levelében az udvartól távol levő ítélőmester tudósítást kért az udvari állapotokról és afelől, hogy feltétlenül hadba kell-e vonulnia, vagy pedig otthon maradhat. ${ }^{317} \mathrm{~A}$ központi iratkibocsátó szerveknél elsajátított tudás, a gyakorlati jogban való jártasság segíthette ôt pályája újabb állomására: 1616-tól már a kolozsmonostori konvent egyik levélkeresője. ${ }^{318}$ Hivatalaiban szerzett keresetét prókátorkodással is kiegészítette, erre vall Vagyas Gáspár 1614. évi bevallása, amely szerint Szőlősi Istvánt - minthogy pereiben védelmezte - fiává fogadja, és jószágaiban örökösévé teszi, egyúttal átenged számára egy házhelyet és két kaszálót Magyarpatán. ${ }^{319}$ Ugyanebben az évben kelt beadványa azt bizonyítja, hogy a vagyonszerzésre még meglévő udvari

\footnotetext{
${ }^{315}$ Életpályájára vonatkozó adatokat lásd Sunkó: Archontológia 314.

${ }^{316}$ Trócsányi: Központi kormányzat 196.

317 1611. május 7. Angyalos János levele Szőlősi István nagyobb kancelláriai íródeákhoz:
} „Egregie domine frater et amice observandissime, post servitiorum meorum commendamus. Álgya meg Isten kegyelmedet minden jókkal. Hogy onnan Zebenből az gyúlésből ide Megygyesfalwara juték, itt az embereket mind szekerek hátán találám, az gazdaasszony penig be ment vala Vasarhelyre, az hajdúságtól való féltekbe, kik mely indisciplinatusok legyenek minden ember tuggya. Akarok méghis kegyelmedtül az én állapotom felöl érteni, lehet-e hon maradásom az hadból vagy nem, mert soha oly kedves jó szerencsjével járnánk is, én ollyan helyre nem kévánkozom, ollyan helyenn is eleghet jártam de méghis inkáb szeretem honn lakni. Azirt uram ha mit efficiálhatott kegyelmetek György uramnál, mentül hamarab lehet, aggya értésemre, de ha kegyelmed ír, bizonyos embertúl írjon kegyelmed. Mondák, hogy Moldowai követek is érkeztek az után hogy mi onnén el oszlottunk, öremest érteném, ha szabad volna, mi járásba voltanak. Egyéb dolog felőll is, az mit kegyelmed által illendő s szabad tudnom, írjon kegyelmed. Eandem fideliter valere cupio. Ex Meggyesfalwa 7. maii 1611". Lásd MOL F25 (Miscellanea), 346. f.

${ }^{318} \mathrm{KmProt}$ XX., címlap.

${ }^{319}$ Bethlen Gábor 1622-ben erősítette meg ezt a szerződést, oklevelében Szőlősiről a következőket írja: „in tabula principali Transilvaniae iudiciariae iurati notarii [...] post vero quod aulicae principum praedecessorum nostrorum ac tandem nostrae etiam cancellariae se addicens $[\ldots]$ in presentiarum etiam in officio requisitoratus dicti conventus de Colosmonostra 
kapcsolatait is felhasználta. Ekkor azért folyamodott a fejedelemhez, hogy a hunyadi harmincados által lefoglalt, csempészett ökrök közül a fiskust megillető hármat neki juttassák. ${ }^{320}$ Talán a Kolozs vármegyei birtokrész megszerzése segíthette Szőlősit abban, hogy a megyei adminisztrációban is szerepet kapjon: 1618-ban Bethlen Gábor salvus conductusát Kolozsváron lakó Szőlősi István részére állítja ki, aki „nem csiak az Colos vármegye adaiának perceptora, hanem az Colosmonostori conventnek is edgyik requisitora". ${ }^{321}$ Saját protocollumába másolt elszámolásaiból tudjuk, hogy e tisztségét egy évvel korábban, illetve 1621-22 között is viselte. ${ }^{322} 1623$-ban a vármegyei nemesség jegyzőjének választotta, de ezt a hivatalt csak rövid ideig viselte, talán a városban pusztító pestisjárvány ragadta el. ${ }^{323}$

\section{Kolozsvári Bágyoni Demeter, másként Hadnagy János 1617-1622}

A Kolozsvárhoz közeli aranyosszéki székely kisbirtokosok közül származott, és értelmiségi pályára lépve kerülhetett a konvent kancelláriájához. Családtagjai közül Kelemen Judit nevü feleségét és fiát, Dánielt ismerjük, aki az 1630-as években tiltakozott a Demeterek bágyoni, szentmihálytelki és kercsedi jószágai ügyében. ${ }^{324}$ Korábbi pályájáról semmi adatunk nincs, 1617-ben már kolozsmonostori levélkeresőként szerepel. ${ }^{325}$ Hivatali szolgálata nem járhatott túl nagy anyagi gyarapodással: 1619-ben csupán egy olcsó Alsó Király utcai faházat tudott vásárolni, további városbeli gyarapodásra, társadalmi emelkedésre már nem volt lehetősége. ${ }^{326}$ Requisitorként

publica Regni ordinumque ei commodo citra omnem quaerelam invigilaret." (KmProt XXI. $\left.32^{r}-34^{r}\right)$.

${ }^{320}$ MOL F25 (Miscellanea), f. 421.

${ }^{321}$ MOL F25 (Miscellanea), f. 433.

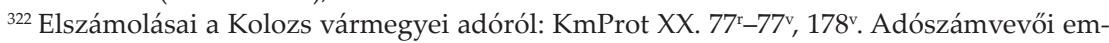
lítése 1622-ből: KmProt XXI. 34r.

${ }^{323}$ Vármegyei jegyzőnek való megválasztásáról és haláláról Kolozs vármegye jegyzőkönyvének 459. lapján található szöveg tájékoztat: „1623. feria IV. post dominicam Quadragesimae ex deliberatione dominorum nobilium Stephanus Szeoleosi requisitor conventus Colosmonostrensis in officium notariatus creatus; 1624 feria III. proxima post dominicam Jubilate post terribilemque et inopinatam Stephani Zeoleosi mortem ex communi eorundem dominorum nobilium consensu et suffragio, electus est in officium notariatus Stephanus Varsoczy." - A Kolozsváron pusztító pestisjárványról lásd Kolozsvári emlékírók 154-155. E járványnak a levélkeresők közül talán ketten is áldozatai lehettek: a requisitorok 1623. február 20-án egy végrendeletet „in quadam signatura praedecessorum nostrorum hisce scilicet elapsis pestilentissimis temporibus, divina voluntate e vivis sublatorum" találtak meg. A nevezett signatura 1622. március 31-én kelt, vö. KmProt XX. 185․ Talán a requisitor fia lehetett az a Péter, aki a konvent előtt 1648-ban tett tiltást anyja, Urbeger Zsófia testamentuma ellen, lásd KmProt XXXIII. 29r.

${ }^{324} \mathrm{KmProt}$ XXIX. 182 ${ }^{\mathrm{v}}$.

${ }^{325} \mathrm{KmProt}$ XIX. $20^{\mathrm{v}}$.

${ }^{326} \mathrm{KmProt}$ XXI. $51^{\mathrm{r}}$. 
utoljára 1622-ben szerepelt. ${ }^{327}$ Talán őt is az ekkor dühöngő pestis ragadta el.

\section{Szentmihályfalvi András 1623 (?)}

Konventi hivatalviselése bizonytalannak tekinthetö, mivel egyetlen adat említi requisitorként. ${ }^{328}$ Szentmihályfalvi András neve 1616-1631 között szerepel a nagyobb kancellária íródeákjainak sorában. ${ }^{329} \mathrm{Ez}$ inkább azt valószínúsíti, hogy Beke tévedésének tulajdonítható kolozsmonostori levélkeresőként való említése.

\section{Tordai Péter 1623-1646}

Származása bizonytalan, talán a tragikus sorsú Kolozsvári János deák fiscalis director Sombori Judit nevű feleségétől született, valamikor a XVI. század végén. Erre egy 1614-ben kelt forrásunk utal, ekkor tordai néhai Kolozsvári János deák özvegye, Sombori Judit és már törvényes korú (tehát 14. életévét betöltött) fia, Kolozsvári Péter deák bevallást tesznek a kolozsmonostori hiteleshelyen. ${ }^{330}$ Ugyanekkor említik Péter deák kiskorú testvéreit, Ferencet és Erzsébetet. Tisztes kolozsvári értelmiségi-polgár családból származhatott tehát Péter deák, és tehetsége mellett a családi háttér - apja bukása ellenére - lehetővé tette számára a hivatali karriert és a társadalmi emelkedést. Egy másik Tordai Péter 1612-ben a fejedelem nagyobb kancelláriáján deákoskodik, egy harmadikat pedig 1618-ban nemesítettek meg. ${ }^{331}$ További kutatások szükségesek ahhoz, hogy a sok Tordai Péter között rendet tudjunk tenni.

Az 1623-ban Kolozs vármegye adószedőjeként említett Tordai Péter viszont már biztosan ő. E tisztségben a vármegyei jegyzővé választott kollégáját, Szőlősi Istvánt váltotta fel. Ugyanebben az évben jelenik meg először konventi levéltárosként is. ${ }^{332} \mathrm{~A}$ hivatali ranglétrán való előrelépé-

\footnotetext{
${ }^{327}$ MOL F25 (Miscellanea), 479. f.

${ }^{328}$ Beke: A kolozsmonostori konvent 549. sz.

${ }^{329}$ Trócsányi: Központi kormányzat 195.

${ }^{330} \mathrm{KmProt}$ XVI. 70'; A Kolozsvári Jánosokra és családjukra vonatkozó adatokat Wolf Rudolf foglalta össze, lásd Torda város tanácsi jegyzókönyve. Bevezető tanulmánnyal és jegyzetekkel közzéteszi Wolf Rudolf. Erdélyi Történelmi Adatok VI. 1. Kolozsvár, 1993. 61-62. (74. és 75. sz. jegyzet). A 74. jegyzetnél, 1585-ben említettek (Mihály, Gáspár és Imre) bizonyára egy másik János deák fiai.

${ }^{331}$ KolJkv $125^{v}$.

${ }^{332}$ Vármegyei perceptori említései 1623: KmProt XXXIII. 79v-80r; 1628: Sunkó: Archontológia 322-323.; 1636: Uo. Requisitori említései Sunkó: Archontológia 322-323. 1633-ban kollégájával, Pécsi Jánossal együtt vette fel Gyaluban Zólyomi Dávid végrendeletét, EOE IX. 366-367. 1638-ban Gyulafehérváron tett vallomást egy feltehetően tévesen kiállított iktató-
} 
sében pártfogója, Bethlen István segíthette, a vármegyei perceptorságra is ő ajánlotta. ${ }^{333} \mathrm{~A}$ fölöttébb terhes adószedői tisztséget hosszú ideig viselte, hivatalából - valószínúleg az adók megkésett befizetése és elszámolása miatt - végül 1636 októberében vagy novemberében menthették fel. ${ }^{334}$

A vármegye mellett a városban is gyorsan lépett előre. 1623-ban már kellő elismertségre és gazdagságra tehetett szert ahhoz, hogy beválaszszák a város életét irányító testület, a százférfiak sorába. ${ }^{335}$ Kolozsváron levő ingatlanai közül csupán azt ismerjük, amely lakóhelyéül is szolgált, és amelyben a gondjaira bízott levéltár egy részét is őrizte. Egy neki küldött levelet így címeztek: „Az én jó akaró uramnak, Colosvarat Hid ucában lakó Péter deák uramnak (úgy mint Captalanban) nekem jó akaró uramnak adassék kezében" ${ }^{336}$ Valószínűleg ebben a házban érhette a halál is, melynek pontos dátumát requisitor-társa, Pálfi István jegyezte fel: 1646. október $2 .{ }^{337}$

Tordai Péter deák hiteleshelyi működésének legkézenfekvőbb emlékei az általa vagy többnyire általa vezetett jegyzőkönyvek. ${ }^{338}$ Ezen protocollumok közül kettőt a későbbi requisitor, Szalárdi János látott el mutatóval,

levél ügyében, lásd ENMLt, Kemény cs csombordi 1t, nr. 814.; 1623 októberében kolozsmonostori requisitor és Kolozs vármegye adószedője: Batthyaneum. A kolozsmonostori konvent levéltára LXXVIII. 117. Elképzelhető, hogy 1637-1640 között is ő viseli a perceptori hivatalt, feltéve, ha az ő kezével keltek az ezen évekre szóló elszámolások. Vö. Batthyaneum. A kolozsmonostori konvent levéltára LXXIX. 10.

${ }^{333}$ 1628-ban kelt Bethlen István levele Kolozs vármegyéhez, melyben arra szólítja fel a nemeseket, hogy az adóbeli restanciákat szolgáltassák Tordai Péter kezéhez, aki „,az kegyelmetek vármegyéjének perceptora, ki ennek előtte való üdőkben egynéhány esztendeigh nekem jámbor szolgám lévén, ugyan én commendaltam vala is arra az állapatra, melyben immmár öt esztendőtől fogva tehetsége szerént, úgy hiszem, hogy kegyelmeteknek vármegyéül kedvesen és nem haszontalanúl is szolgált". Lásd MOL F25 (Miscellanea), f. 514.

${ }^{334}$ 1636. október 22-én Gyulafi Sámuel, Serédi István és Tholdalagi János az alábbi módon „,fenyegették” Tordai Pétert a restanciák miatt: „Az urunk ő nagysága kegyelmes fejedelmünk ez esztendőbeli fel vetet adajának utólszori administratioja [...] részint restantiaban lévén, csudálkozunk rajta, hogy ez ideig is való perceptiot beszolgáltatni enni ideigh halasztotta, megh nem gondolván mostani állapathoz képest az ő nagysága fizetet hadai hópénzbeli fizetésekre való kiválképpen való szükségit. Elhivén, hogy az contributio restantiaiban jó részint percipialhatott is, holot azért urunk ő nagysága immár erről kegyelmesen demandalt is. Intjük kegyelmedet, sőt ex autthoritate a sua Celsitudinis nobis attributa, hadgyuk és igen serio parancsolljuk, ez levelünket vévén, valamit kegyelmed ez ideigh az vármegye adajában percipialhatot és ez utánn is percipialandó, minden haladék nélkül szolgáltassa be ide Fejervarra ő nagysága praefectussa és exactora keziben. Mert ha kegyelmed ebben valami fogyatkozást teszen, és az administratioját halogattja, urunk ő nagysága kegyelmes fejedelmünk gravis animadversioját veszi." - 1636. november 26-án már Péter deák konventi kollégája, Pálfi István az adószedő (MOL F25, Miscellanea, f. 62-63).

${ }^{335}$ Binder 1982. 301. 1642-ben is centumpater: KmProt XXVII. 77v.

${ }^{336} \mathrm{KmProt} X X V .73^{v}$.

${ }^{337}$ Sunkó: Archontológia 322-323.; KmProt XXXI. 3r.

${ }^{338}$ Sunkó: Archontológia 322-323. 
egyet pedig biztosan ő mentett meg a pusztulástól azzal, hogy a Péter deák által lejegyzett szövegeket egybekötötte. ${ }^{339}$

\section{Csanádi Pál 1625-1636}

A kolozsmonostori konvent egyik legismertebb levélkeresője, de hírnevét nem levéltárosi, hanem egyházi, irodalmi és az oktatásban betöltött szerepeinek köszönheti. ${ }^{340}$ Külföldi egyetemeken is tanult. ${ }^{341}$ Konventi requisitorként először 1625-ben említik, ${ }^{342}$ és e tisztségét élete végéig megtartotta. Pálfi István előtt ő lehetett a hiteleshely vezetője (conservatora?), de egyéb hivatalaival járó elfoglaltságai miatt feltételezhetjük, hogy egyre kisebb szerepet tudott vállalni a hiteleshely múködtetésében. Amikor 1626-ban Bethlen Gábor megerősíti a kolozsvári unitárius iskola kiváltságait, Csanádi Pál már 19 éve betölti az iskola rektorságát, emellett orvos és csak „utolsósorban” a konvent egyik requisitora. ${ }^{343}$ 1632-ben unitárius püspöknek is megválasztották, ezután még kisebb lehetett szerepe a hiteleshelyi oklevelek kiállításában. ${ }^{344} 1636$. december 3-án ragadta el a halál, "nagy solennitással” temették el a Házsongárdi temetőben. ${ }^{345}$

\section{Pálfi István 1627-1667}

Jakó Zsigmondnak köszönhetően életéről és a konventi levéltár rendezésében és megmentésében betöltött szerepéről viszonylag sokat tudunk. ${ }^{346}$ Már ifjú korában Bethlen István tanácsúr udvarában írnokoskodott, innen került előbb a fejedelem nagyobb kancelláriájára, majd 1627-től

\footnotetext{
${ }^{339} \mathrm{KmProt}$ XVIII. elején levő index 176. lapja.

${ }^{340}$ Ezekről bővebben lásd Kénosi Tőzsér János-Uzoni Fosztó István: Az erdélyi unitárius egyház története I. Fordította Márkos Albert. A bevezető tanulmányt írta és a fordítást a latin eredetivel egybevetette Balázs Mihály. Kolozsvár, 2005. 444-446.; Gál: Unitárius kollégium 393-395. Életrajzi adatait röviden összefoglalta Szabó-Tonk: Egyetemjárás 214. (2187. sz.), és lényegében ennek alapján Sunkó: Archontológia 315.

${ }^{341}$ A padovai egyetemet látogatta, lásd Szabó-Tonk: Egyetemjárás 214. (2187. sz.). 1626-ban a bölcsészet- és orvostudomány doktoraként említik, az orvoslást gyakorolta is. Vö. Herepei: Adattár I. 266.

${ }^{342}$ KmProt XXIII. 101".

${ }^{343} \mathrm{KmProt}$ XXI. 101" : „scholae Claudiopolitanae publicae iam ab annis decem et novem rector, philosophiae et medicinae doctor ac in conventu Beatae Mariae Virginis de Colosmonostra litterarum requisitor."

${ }^{344}$ Püspökké választásáról és jelleméről lásd Kolozsvári emlékírók 163.

${ }^{345}$ Sunkó: Archontológia 315.; Kolozsvári emlékírók 169. Sírfeliratát közli Herepei: Házsongárd 193-194. Az egykori domonkos kolostor, majd unitárius kollégium belső udvarán látható emléktáblájának szövegét lásd Lőwy Dániel-Demeter V. János-Asztalos Lajos: Kőbe irt Kolozsvár. Emléktáblák, feliratok, címerek. Kolozsvár, 1996. 42-43.

${ }^{346} \mathrm{KmJkv}$ I. $145-146$.
} 
biztosan a kolozsmonostori hiteleshelyhez, annak egyik requisitoraként. ${ }^{347}$ Valószínúleg a Fehér vármegyei Enyed mezőváros polgárai közül lépett hivatalnoki pályára, nemességet és címeradományt írnoki szolgálataiért 1623 táján kapott. ${ }^{348}$ Karrierjét leginkább különösen szép kézírásának köszönhette, s noha katolikus volt, a fejedelem őt választotta ki mint ,,jó kezű deákot", hogy letisztázza az 1636-ban Öreg Graduálként kinyomtatott kálvinista énekeskönyv összegyuujtött anyagát. ${ }^{349} \mathrm{E}$ munkájának köszönhette kolozsmonostori requisitorságát. ${ }^{350}$

Pálfi levélkeresőként is maradandót alkotott. 1640 körül kezdte el a levéltár rendezését, és feladatával 1648 táján készülhetett el. Ebben az évben kelt utasítása requisitor-társai részére, melyből kiderül, hogy Pálfi a levéltár régebbi anyagát elválasztotta a gyakrabban használt újabbtól, tárgyi csoportokba és ládikákba helyezte a leveleket, majd mutatókat készített hozzájuk. ${ }^{351}$ Neki köszönhetően állott össze a levéltárban őrzött minutákból a XV. századi jegyzőkönyvek nagy része, és ugyancsak ő készíthette, középkori szertartáskönyvek hártyáját is felhasználva, a mai kötéseket. A levéltár megőrzése és rendezése érdekében kifejtett tevékenysége mellett Pálfi azt is igen jól látta, hogy minden munkája hiábavalóvá válhat, ha nem oldják meg a levéltár elhelyezésének súlyos, a fejedelemség korszakát végigkísérő gondját. 1655-ben kelt felterjesztésében, melyet csak fogalmazványként ismerünk, sürgette a megoldást, és azt javasolta, hogy a konventi anyagot egy helyen, a Monostoron levo „mángorló házban” helyezzék el és ott őrizzék. ${ }^{352}$ Megszűnt volna ezzel az a gyakorlat, hogy a leveleket a

\footnotetext{
${ }^{347}$ KmProt XXI. 114v.

${ }^{348}$ MOL F1 (Libri regii). X. p. 352-353. - A címerleírást magyar fordításban közli Sunkó: Archontológia 316-317.

${ }^{349} \mathrm{KmJkv}$ I. 145. - Az Öreg Graduálról és Pálfi István személyéről lásd még Kurta József: Az Öreg Graduál századai Erdélyben. Erdélyi Református Egyháztörténeti Füzetek 8. Kolozsvár, 2002. 10-12.

${ }^{350}$ Pálfinak a konventi tisztséggel való jutalmazásáról lásd uo. 110: „mert a maga öregbik Cancelláriáján levő jó kezű Deákkal Pálfi Istvánnal, kit munkájáért az Colosmonostori Conventnek tisztivel jutalmaztata megh (...) leíratá." (Ismeretlen kéz bejegyzése a Graduál egyik példányán.)

${ }^{351} \mathrm{KmJkv}$ I. 145.

${ }^{352}$ Pálfi szövege: „Rendelne egy conventualis locust, melyet [...] privilegialna is, hogy az kik requisitorok lenének laknának egy helyben és ott [...] procedalnának, juxta officii exigentiam debito modo. Erre penig egy alkalmatos helt nem találunk mint [?] Monostoron vagyon egy mángorló ház, ki nem sok épülettel igen alkalmatos lene erre az szükségre, ott mindeneket szép rendbe [...] ládákba helyeztetve (Isten kitől oltalmazzon), háborúságnak idején, mind ládástól kenyő volna behozni az várasban, mint ennek előtt is..." KmProt XXXV. (számozatlan lapok)
} 
requisitorok szállásán tartsák, maga Pálfi is tapasztalta már, mekkora veszélyekkel járhat az, ha a saját Farkas utcai háza szolgál levéltárként. ${ }^{353}$

Pálfi István tervének az elkövetkező szomorú idők nem kedveztek. Talán neki is köszönhető, hogy amikor 1658-ban a tatár had rászakadt Erdélyre, a levéltárat vagy annak egy részét a biztonságosabb szamosújvári várba menekítették. Mikor a veszély elmúltával a levéltári anyag visszakerült a városba, minden maradt a régiben: a leveleket továbbra is a requisitorok szállásain őrizték.

Pálfi művelt, könyvszerető ember volt, de arról, hogy a tudását hol szerezte s miképpen gyarapította, semmit nem tudunk. Már 1625-ben, kancelláriai deákként bejegyezte nevét Joannes de Verdena 1509-ben megjelent könyvébe, ${ }^{354} 1630$-ban pedig a csíksomlyói ferenceseknek ajándékozott könyveiből. Könyveinek fennmaradt jegyzéke sokrétű és kivételes műveltségéról tanúskodik. ${ }^{355}$

Keveset tudunk arról, hogy mekkora anyagi és társadalmi elismerésben részesült. 1640-től került a kolozsvári centumvirek közé, ${ }^{356}$ ekkor a város már befogadta és talán így jutalmazhatta a közösség azt, hogy udvari kapcsolatait a civitas érdekében is felhasználta. Udvari összeköttetéseit Pálfi nem vonakodott időnként saját érdekében is kamatoztatni, noha ez nem mindig hozott számára anyagi hasznot, sőt esetenként még veszteséggel is járhatott. ${ }^{357}$ Hivatali szolgálatait úgy tünik, nem jutalmazták birtokadománnyal. 1636-ban Rákóczi György fejedelem sem jószágot, hanem évente 500 kősót adományozott a dési aknáról Pálfi István részére. ${ }^{358}$ Talán jövedelmei kiegészítéséért vállalta el ugyanebben az évben a Kolozs vármegye nem kis teherrel járó adószedői tisztségét, melyet még 1640-ben is viselt. ${ }^{359}$

\footnotetext{
${ }^{353} 1648$. október 1-jén a fejedelem két ittas állapotban levő udvari familiárisa Pálfi requisitor Farkas utcai házában garázdálkodott: „,noctis in silentio, tempore jam plane ad undecimam horam nocturnam urgente ad domum ipsius exponentis, eam videlicet, quae pronunc exeo quod ea omnia litteralia instrumenta quae alias alibi locata habebantur, in ipsa domo exponentis continerentur, pro sacristia sive conservatorio conventus Colosmonostrensis reputaretur, in platea Luporum, intra moenia dictae civitatis regiae Colosvar situatam ac vicinitatibus domorum ab orientali [...] circumspecti Martini Szindi, ab occidentali vero plagis Stephani Baczi junioris [...] ipso domus hospite potentiose irruissent et invasissent". MOL F25 (Miscellanea), f. 339-340.

${ }^{354}$ Jakó Klára: Az első kolozsvári egyetemi könyvtár története és állományának rekonstrukciója 1579-1604. Erdélyi Könyvesházak I. Szeged, 1991. 131.

355 Jakó Klára: Betüművész 37-38.

${ }^{356} \mathrm{KmProt}$ XXVII. 69v; Binder 1982. 303.

${ }^{357}$ Egy címereslevél protocollumbeli kihúzott másolata alatt olvasható Pálfi alábbi szövege: „Ennek az bestye kurva fiának ezt az armalist én magam szerzettem és írtam vala, és szépen el készítven, publicaltatván, czimerét is meg íratván, rajtam hagyá, melyet az cancellarius eleiben vittem és ott cassalták, annihilalták, oda az én költésem". (KmProt XXVII. 30).

${ }^{358} \mathrm{KmProt}$ XXVIII. 129 .

${ }^{359}$ MOL F25 (Miscellanea II.), 63v , 589v.
} 
A forrásokban utoljára 1667-ben szerepel, ekkor requisitori tisztsége mellett - előrehaladott kora ellenére - a török adó generális perceptora volt. ${ }^{360}$

\section{Pécsi János 1633-1642}

Baranyából, neve szerint éppen Pécs városából került Kolozsvárra, a török elől menekülők sokaságával együtt. ${ }^{361} 1622-1633$ között a fejdelem nagyobb kancelláriáján jegyző, ebben az időszakban talán külföldön is peregrinált. ${ }^{362}$ Kolozsváron, 1623-ban már a százférfiak között szerepelt, sikerült tehát beilleszkednie a városi közösségbe, ekkor már biztosan családot is alapított, és örökséget is szerzett magának. ${ }^{363} \mathrm{~A}$ konventi hiteleshely levélkeresőjeként 1633-tól említik, ebben az évben szállt ki társával, Tordai Péterrel együtt Gyalu kastélyához, hogy írásba foglalják Zólyomi Dávid testamentumát. ${ }^{364} \mathrm{~A}$ fejedelem megbízásából gyakran végzett tanúvallatásokat, foglalt írásba urbáriumokat. ${ }^{365}$ Hasonló jellegű szolgálatai jutalmaként, nevezetesen a székelyek összeírásáért adományozta neki és feleségének Rákóczi György a horgaspatakai részjószágot. ${ }^{366}$ Ehhez a jószágához járultak saját Kolozs vármegyei szerzeményei, melyek után a vármegye 1641. évi lustrálásakor egy felszerelt lovat kellett hadba állítania..367 Pécsi János Kolozsváron levő házát felesége, Rázmán Anna jussán birtokolta, felesége révén válhatott tehát kolozsvári polgárrá. ${ }^{668}$

\footnotetext{
${ }^{360}$ Trócsányi: Központi kormányzat 309.; EOE XIV. 231.

${ }^{361}$ Sunkó: A Gyulafehérvári Káptalan 102.

${ }^{362}$ Herepei szerint 1622. november 19-én társával, Dengelegi Péterrel „a fejedelem deáki” Gyulafehérvárról érkeztek Kolozsvárra és innen indultak külföldre tanulni. Lásd Herepei: Adattár I. 303.

${ }^{363}$ Binder 1982. 302.

${ }^{364}$ EOE IX. 366-367.

${ }^{365}$ 1635. május 4-én Beszterce vidékén járt executióban (KvNLt, Beszterce város levéltára, nr. 11162.); 1639-ben a kővári uradalom urbáriumát állította össze, lásd Makkai: Rákóczi György 426.

${ }^{366} \mathrm{Az}$ 1636. március 6-án kelt adomány indoklása: „attentis et consideratis fidelitate fidelibusque servitiis egregii Joannis Peczi de Colosvar, alterius requisitoris conventus Colosmonostrensis, quae cum antea in principali cancellaria nostra superioribus ab hinc annis [...] in expediendo omnis generis literis rebusque nostris suae diligentiae commissis, tum etiam presente matrimonialis sui status tempore, tum in hoc moderno suo requisitoratus a nobis ipse clementer collato [...], quam in nonnullis generalium [?] Siculorum nostrorum connumeratorum regestris describendo, aliisque cunctis in negotiis nostris pro diversitate temporum ipsi demandatis, fideliter et constanter exhibuit et impendit" (MOL F1. 21. 123 ${ }^{\mathrm{r}}-123^{\mathrm{v}}$ ).

${ }^{367} \mathrm{KmProt}$ XXIX. 173r.

${ }^{368}$ Sunkó: A Gyulafehérvári Káptalan 103.
} 
Pécsit 1642. április 3-án temették el, ${ }^{369}$ végrendeletében mindenét feleségére hagyta, de nem feledkezett meg az őt befogadó városról és az iskola „unitária religión levo"” diákjairól sem. ${ }^{370}$

\section{Pécsváradi János 1635-1644}

Először 1635-ben szerepel mint a kolozsmonostori konvent egyik requisitora. ${ }^{371}$ Életpályájáról csupán elszórt adatokkal rendelkezünk. 1639-1641 között a nagyobb kancellárián találjuk jegyzőként, úgy tünik, ő lehetett a kolozsmonostori konvent requisitorai közül az egyedüli, aki a konventi és a fejedelmi íródeáki hivatalt egyszerre viselte. ${ }^{372} 1643$-ban a kolozsvári borbélyok céhszabályait fordítja magyar nyelvre. ${ }^{373}$ Halála pontos időpontját kollégája, Pálfi István jegyezte le: 1644. július 30. ${ }^{374}$ Könyvei közül egyedül a Bécsben élő spanyol jezsuita, Ambrosius de Penalosa müve maradt ránk. ${ }^{375}$

\section{Kászoni József 1646-1659}

Neve alapján székelyföldinek vélhetnénk, származásáról viszont a konvent jegyzőkönyveiben tett bejegyzése egyebet vall: „cum superioribus diebus ex benigna [...] illustrissimi domini principis annuentia nobilis Josephus Kaszoni alter collega noster in et ad oppidum Kaszon, in comitatu Beregiensi existentem habitam, patriam videlicet suam propter ardua [...] negotia profectus fuisset" ${ }^{376}$ Elöször a fejedelem kisebb kancelláriáján szerepel 1641-1644 között írnokként, majd onnan 1646-tól a kolozsmonostori hiteleshely levéltárához került..377 Pálfi István gyakran panaszkodott, hogy Kászoni Désen levő birtoka miatt vagy a fejedelem

\footnotetext{
${ }^{369}$ Fasciculus rerum 156.

${ }^{370}$ 1637-ben kelt testamentumát 1642-ben egészíti ki. A szövegeket közli Sunkó: A Gyulafehérvári Káptalan 101-106.

${ }^{371}$ KvNLt, Beszterce város lt, nr. 11162.

372 Trócsányi: Központi kormányzat 194.

${ }^{373}$ Jakab: Oklevéltár II. 320.

${ }^{374}$ Sunkó: Archontológia 318.

${ }^{375}$ Possessor-bejegyzés az Opus egregium de Christi et Spiritus Sancti Divinitate necnon SS. Trinitatis mysterio contra Judaeos, Photium, Socinum, Eniedinum, aliosque veteres et novos arianos R.P.D. Ambrosio de Penalosa Mondexarensi S. J. Viennae Austriae, 1635, Matthaeus Formica c. könyv címlapján: „Ex libris Joannis Peczvaradi aliter requisitoris Conventus Colosmonostrensis." Vö. Kolozsvár, Marosvásárhely, Nagyenyed, Szászváros, Székelyudvarhely. Erdélyi Könyvesházak II. Szeged, 1991. (Adattár 16/2) 13.

${ }^{376}$ KmProt XXXIII. 10 .

${ }^{377}$ A kisebb kancellária íródeákja, lásd Trócsányi: Központi kormányzat 368.; MOL F25 (Miscellanea II.), f. 272, 299. Requisitori említései: 1646: KmProt XXXI. 82v, Sunkó: Archontológia 315.; 1659: KmProt XXXIII. 150v.
} 
ügyeiben (in negotiis principis) eljárva távol volt, emiatt a hiteleshelyi teendőket egyedül kellett végeznie. ${ }^{378}$ Valójában viszonylag sürűn szerepel Kászoni uradalmak inventáriumainak összeállítójaként, ${ }^{379}$ illetve biztosan dési háza és családja gondjai is eléggé lefoglalhatták. ${ }^{380} 1652$-ben Rhédei Ferenc tanácsúr a jogbiztosító levelek kikeresésében tanúsított szolgálataiért adományozhatta Kászoninak saját Désen lakó jobbágyát. ${ }^{381}$ Dési házát az 1658. évi tatár pusztítás alaposan megviselhette. 1659 márciusában Barcsai Ákos fejedelem utasította dési sókamarását, hogy Kászoni József „,colosmonostori egyik requisitor" részére utalja ki a 4000 kősót, az „mostani meg romlott dési házának élpületire". 382

Kászoni József hivatalával járó kis jövedelmét alkalmanként „könyvkereskedéssel" is kiegészítette, 1655-ben a Máramaros megyei Técső mezőváros lakosai nyugtatták afelől, hogy „egy Articulust, Constitutiones videlicet Regni Transilvaniae et Partium Regni Hungariae eidem annexarum" kézhez vettek, és az első adandó alkalommal négy nyestbőrt, jókat és szépeket küldenek cserében. ${ }^{383}$ Adatok hiányában nem sikerült eldönteni, hogy milyen (üzleti/rokoni) kapcsolat kötötte nagyenyedi Barakonyi Sámuelhez, akinek néhai kollégája, a kisebb kancellárián dolgozó Udvarhelyi György „stilionaris könyvét”, tehát formuláskönyvét adományozta, kikötve, hogy Barakonyi magtalan halála esetén az őt illesse. ${ }^{384}$

\section{Benkő Bálint 1654-1661}

A székely eredetű, unitárius Benkő Bálint pályája a kisebb kancellárián indult, 1639-1640 között az ítélőmesterek mellett írnokoskodott. ${ }^{385}$ 1647-ben Kolozs vármegye alszolgabírája, 1650-ben pedig már a megye

\footnotetext{
${ }^{378}$ Pálfi lényegében szabálytalanul járt el, amikor társai távollétében foglalt írásba bevallásokat. Ezekben mindig meg is jegyzi, hogy a kollégái nem voltak jelen: „Coram me Stephano Palffi collega in negotio illustrissimi domini principis absentis." (KmProt XXXI. 115); ,,altero collega nostro decedente, altero vero in negotiis ill. suae celsit. absente, coram uno nostrum in loco videlicet testimoniali et conventuali personaliter comparentis" (KmProt XXXI. 126r).

${ }^{379}$ 1648-ban a porumbáki uradalom inventáriumát állította össze, lásd Makkai: Rákóczi György 511.; 1652-ben kalotaszegi birtokok urbáriumát írja, lásd Jakó: Gyalu 94.

${ }^{380}$ A dési jószág felesége, a mezővárosi polgár Erdős Mihály leánya, Judit jussa volt, lásd KmProt XXXII. $66^{\mathrm{r}}-66^{\mathrm{v}}$.

${ }^{381} \mathrm{KmProt}$ XXXIII. 80v.

${ }^{382} \mathrm{KmProt}$ XXXIII. $150^{\mathrm{v}}$.

${ }^{383}$ Vélhetően az Approbbata Constitutiók kéziratos másolatáról vagy kinyomtatott példányáról lehetett szó.

${ }^{384} \mathrm{KmProt}$ XXXIII. 132r. A Fehér vármegye jegyzői tisztjét viselő Barakonyi Sámuelről és családjáról lásd Erdélyi Pál: A Teleki-énekeskönyv. Második közlemény. In: Erdélyi Múzeum XXIV (1907). 182-184.

${ }^{385}$ Trócsányi: Központi kormányzat 366.; SzT V. 167.
} 
nótáriusa és perceptora volt, ${ }^{386}$ és ezen hivatalaiban talán haláláig megmaradt, sőt 1658-ban a vármegye őt küldte követként az országgyűlésre. ${ }^{387}$ Semmit nem tudunk arról, hogy miként lett Benkő vármegyei tisztviselö, és hogy miként került Kolozsvárra, de ekkor már feltehetően vármegyei birtokkal is rendelkezhetett. 1654-től a konvent levélkeresői tisztségét is viseli. ${ }^{388}$ Kolozsváron biztosan felesége, a város jegyzőjének leánya, Pulacher, másként Conrad Borbála révén és udvari kapcsolatai, illetve fontos hivatalai hátszelével verhetett gyökeret; 1653-tól már a centumvirek között említik. ${ }^{389} \mathrm{~A}$ városban több ingatlanra is szert tett, a Monostor utcai fertályban két háza volt, a tanácsház melletti házat pedig bérelte. ${ }^{390}$

Benkő hivatalviselésének és kapcsolatainak köszönhette birtokai gyarapodását is. A Kassaiak vélhetően prókátori szolgálataiért adták neki a Kolozs megyei Fejérden levő puszta házhelyüket, ${ }^{391}$ Kamuthi Farkas pedig azért adományozza a Doboka vármegyei Kovácsiban levő jószágát, mert „Déva várában való fogságakor nem csak kevés attyafiságos jóakarattal telljes szolgálattját mutatta megh ő kegyelméhez tapasztalható képpen megh írt Benko Bálint uram, hanem mégh az tulajdon maga ezüst marháját, ezüstös aranyas bottját is oda küldötte ő kegyelmének, hogy azzal is Kamuthi Farkas uram ő kegyelme az mi kegyelmes urunk ő nagysága méltóságos személye előt érette való törekedésre jóakarókat szerezhessen velle magának, mely bot megh ért volna 65 forintot". ${ }^{392}$ Ügyvédként szolgálhatott Ördög Istvánnak is, aki birtokai visszaszerzésében nyújtott segítségéért neki adományozta a szintén Doboka vármegyei Sólyomkőn levő jobbágytelkét, és ugyanott egy nemesi fundust nála zálogosított el, ${ }^{393}$ és szintén prókátori tevékenységével egészítette ki újabb szerzeményekkel az említett Kovácsiban található „uradalmát” ${ }^{394}$ A források utoljára 1661-ben

\footnotetext{
${ }^{386}$ Herepei: Házsongárd, 274. lapot követő családfa; MOL F1. XXX. 133. Nótáriusi említései: KmProt XXXIV. 16 ; Sándor: Czímerlevelek I. füzet (1551-1629). Kolozsvár, 1910. 103. és uo. II. füzet 93.; KmProt XXXVI. $6^{\text {r }}$.

${ }^{387}$ EOE XI. 356.

${ }^{388}$ Sunkó: Archontológia 314.

${ }^{389}$ Binder 1982. 305. Talán második felesége származott a kolozsvári polgár Csanádi családból, 1659-ben ugyanis ettől az asszonytól való mostohafiai tiltakoztak, lásd KmProt XXXVI.

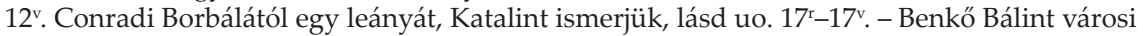
tisztségei: centumvir 1653-1661 (Kolozsvár város lt, Tanácsülési jegyzőkönyvek, Tjkv I/VII. 47., 58., 76., 91., 108., 141., 157., 188., 224.), számvevő 1654-1655, 1657-1659 (Tjkv I/VII. 73., 89., 123., 153., 183.), az 1660. évi rendkívüli adó beszedője (Kolozsvár város 1t, Számadáskönyvek 32/37. cs. 1. p.), divisor 1661 (Tjkv. I/VIII. 6., 38.)

${ }^{390}$ 1659: KvNLt, Kolozsvár város 1t, Számadáskönyvek 33/7., 4., 6.; 33/8., 22.

${ }^{391}$ MOL F1. XXX. 696-697.

${ }^{392}$ MOL F1. XXX. 133.

${ }^{393}$ Batthyaneum. A kolozsmonostori konvent levéltára. LXXIX. 30.

${ }^{394} \mathrm{KmProt}$ XXXIV. $45^{\mathrm{v}}$.
} 
említik; ekkor „,collega társával” Lutz Istvánnal együtt saját kolozsvári házában valami leveleket válogat. ${ }^{395}$

\section{Szőlősi Gábor 1654-1657}

Törzsökös kolozsvári unitárius polgárcsaládból származik, először 1645-ben találkozunk nevével, ekkor az unitárius iskolában tanuló 5 diáknak alamizsnát ad. ${ }^{396} 1651$-ben a város egyik dispensatora, 1654-ben pedig már esküdt polgár és ugyanakkor a konvent requisitora. ${ }^{397}$ Gazdag kolozsvári polgárként több Kolozs vármegyei birtokrész felett is rendelkezett. ${ }^{398}$ Levélkeresői tisztségében utoljára 1657-ben találjuk: ekkor Rhédei Ferenc fejedelem hozzá intézte parancslevelét, hogy requisitor-társával együtt tétesse le az esküt a fiskális várak őrségeivel. ${ }^{399}$ Ugyanebben az évben még egyszerre viseli a levélkeresői és a királybírói hivatalt. ${ }^{400}$ Életpályája következő szakaszai már kizárólag szülővárosához köthetők, 1658-ban kolozsvári főbíróvá választották, és azután is folyamatosan a város szűkebb vagy tágabb tanácsának tagja. ${ }^{401}$ 1661-ben a kolozsvári unitárius egyházfiak számadását végzi. ${ }^{402} \mathrm{~A}$ város tekintélyes összeggel, $706 \mathrm{Ft}$-tal tartozott neki, amiért 1665-ben arról biztosították, hogy a lekötött sörkocsmát továbbra is kezénél hagyják. ${ }^{403} 1668$-ban a város egyik assessora. ${ }^{404} 1672$. május 20-án temették el, özvegyét, Fenesi Borbálát és Mária nevű leányát hagyta hátra. ${ }^{405}$

${ }^{395}$ SzT VII. 47.; Herepei szerint halála 1665. november 10. előtt következett be, lásd Herepei: Házsongárd, 274. lapot követő családfa.

${ }^{396}$ Fasciculus rerum 177.

${ }^{397}$ Herepei: Adattár II. 376.; Sunkó: Archontológia 321.

${ }^{398}$ Sunkó: Archontológia 321.

${ }^{399}$ EOE XI. 329.

${ }^{400}$ KmProt XXXVI. 67v.

${ }^{401}$ 1658-as főbírói említése, lásd EOE XI. 356.; 1659, 1665 centumvir: Binder 1982. 306.; 1668 esküdt: uo. 285.; 1670 februárjában Kolozsvár követe a gyulafehérvári országgyülésen: KvNLt, Kolozsvár város lt, fasc. II. 207/272. sz. mikrofilmtekercs.

${ }^{402}$ Kolozsvári Unitárius Egyházközség Levéltára, Egyházfiak számadásai II.

${ }^{403}$ KvNLt, Tanácsi jegyzőkönyvek I/8. 139-140.

${ }^{404}$ KvNLt, Törvénykezési jegyzőkönyvek VI. 465.

${ }^{405}$ Herepei: Házsongárd 320.; Szőlősi Gábor városi tisztségei: centumpater (1648, 1653, 1655, 1659-1663), sáfárpolgár (1651), számvevő (1652-1653, 1659-1660, 1665), divisor (1653, 1655, 1659-1660, 1665, illetve néhai Benkő Bálint helyett 1661. aug.), vonásigazító (1654-1655, 1659-1660, 1665), kőfalak oculatora (1653-1654), adószedő (rendes adó - 1654; a törökök miatt kirótt adó: 1658. szept. 17.), senator (1656), királybíró (1657), főbíró (1658), a város generalisa másodmagával (1661. júl. 11.), tüzet okozó épületek lerombolásának felügyelője (1661. aug.), a praesidiumnak kiutalt pénz egyik inspektora (1664. aug.), a város inspektora (vagy kapitánya: 1665. okt. 5.), vármegyei assessor a városi rendből (1667. november 7.). 


\section{Szamosközi Mihály 1656-1661}

Talán a történetíró Szamosközi István atyafiságához tartozott, de bizonyítékkal erről nem rendelkezünk. Nevével először a nagyobb kancellárián találkozunk, itt írnokoskodott 1631-1633 között.406 Innen, kissé szokatlan módon nem Kolozs vármegyéhez, hanem Dobokához került előbb adóperceptorként, ${ }^{407}$ majd mint nótárius 1640-1653 között a közgyűlési jegyzőkönyveket vezette. ${ }^{408} \mathrm{Az} 1650$-es években a vármegye rendszerint országgyưlési követei közé választja. ${ }^{409}$ Jövedelmeit vélhetően tetemes öszszeggel egészítette ki azzal, hogy gyakran prókátori feladatokat is elvállalt. ${ }^{40}$ 1648-ban például a Máramaros vármegyei alsóapsaiaktól azért, hogy egy határjárás alkalmával érdekeiket képviselje, 50 Ft-ot és egy jó paripát kívánt. ${ }^{411}$ A korszak egyik legtehetségesebb és legtöbbet kereső ügyvédje lehetett, nemcsak magánszemélyek, hanem Kolozsvár városa is foglalkoztatta, 1656-ban pedig már a kincstár egyik ügyésze (fiscalis procurator) volt. ${ }^{412}$ Kolozsváron több házzal is rendelkezett (Monostor utcai fertályban, Szentegyház utcában). ${ }^{413}$ A konventi levélkeresői hivatalt 1656-1661 között viselhette. ${ }^{414}$ Biztosan katolikus vallású volt, 1655-ben ugyanis a kolozsmonostori katolikus egyház egyik aedilise. ${ }^{415} \mathrm{Az}$ ő kötetei közül kerülhetett Bethlen Elekhez az a kézirat, melyben Báthory Zsigmond cselekedeteit örökítették meg. ${ }^{416}$

\footnotetext{
${ }^{406}$ Trócsányi: Központi kormányzat 195.

${ }^{407}$ KmProt XXVIII. 102v.

${ }^{408}$ Doboka vármegye jegyzőkönyvei a MOL-ban, a Kolozsmonostori Konvent Levéltárának Miscellanea fondjában maradtak fent (F25).

${ }^{409}$ MOL F25 (Miscellanea II.), f. 195-196., 228.; EOE XI. 356.

${ }^{410} 1655$-ben szerepel prókátorként lásd ENMLt, Mike Sándor gyűjtemény, nr. 953.

${ }^{411}$ MOL F25 (Miscellanea II.), f. 345.

${ }^{412}$ 1660-ban prókátori szolgálataiért 30 Ft-tal maradt adósa a város (KmProt XXXVI. 31 $)$; Ügyészi említése: KmProt XXXVI. 61 .

${ }^{413}$ 1659: KvNLt, Kolozsvár város 1t, Számadáskönyvek 33/7, 7. p.; 33/8, 2. p. (Szász Anikó adata).

${ }^{414}$ Sunkó: Archontológia 320.; KmProt XXXVI. 16v.

${ }^{415} \mathrm{KmProt} X X X V .20^{\mathrm{v}}$.

${ }^{416}$ Az 1683-ban összeállított könyvjegyzékben szerepel „egj irot konjv Szamosközi Mihalye de rebus Sigismundi Bathori", lásd A Bethlen-család és környezete. Az Apafi-család és környezete. A Teleki-család és környezete. Vegyes források. Erdélyi könyvesházak III. (Sajtó alá rendezte Monok István, Németh Noémi, Varga András). Adattár 16/3. Szeged, 1994. 21.
} 


\section{Rákosi Boldizsár 1659-1694 előtt}

Családja Aranyosrákosról származott Kolozsvárra. Tanulmányait előbb a városban, majd 1651-től külföldön, a padovai egyetemen végezte, ahol 1655-ben az orvostudomány doktorává avatták. ${ }^{417}$ Hazatérte után az unitárius kollégiumban tanít, 1659-től pedig a konventi hiteleshely requisitori tisztét is betölti. Kolozsvári háza mellett Abrudbányán is birtokolt egy ingatlant. Családtagjai közül feleségét, Szőrös Borbálát, továbbá Boldizsár és Ilona nevű gyermekeit ismerjük. ${ }^{418} 1670$-ben ",captalani tiszti szerént” az országgyủlésen jelenik meg. ${ }^{419}$ Ebből arra következtethetünk, hogy a hiteleshelyek küldöttjei „hivatalból” részt vettek a fejedelemség kori országgyüléseken.

\section{Lutz István 1661-1670}

Kolozsvári szász polgárcsalád sarja, 1655-ben már a város unitárius senatorai között említik. ${ }^{420}$ Levélkeresői müködéséről viszonylag kevés adattal rendelkezünk, 1661-ben szerepel először mint Benkő Bálint „,collega tarsa". ${ }^{421}$ 1665-ben már Rákosi Boldizsár társaságában jelenik meg levélkeresőként,, ${ }^{422}$ utoljára pedig 1670-ben említik mint „captalan"-t, ekkor egy felhatalmazás megírásáért egy forintot kapott. 1675-ben neve a kolozsvári centumvirek között szerepel. ${ }^{423}$ Elképzelhető, hogy a levélkeresőnk azzal a Lucs Istvánnal azonosítható, aki 1652-1656 között a nagyob kancellária írnokaként működött, 1655-ben és az ezt követő évben pedig a fejedelem követe volt a kozákoknál. ${ }^{424}$ Akkor viszont Altdorfban, Padovában és Königsbergben is tanult. ${ }^{425}$

\footnotetext{
${ }^{417}$ Életrajzának összefoglalása: Gál: Unitárius kollégium II. 402.; Szabó-Tonk: Egyetemjárás 26. (249. sz.); Sunkó: Archontológia 318-319.

${ }^{418}$ Sunkó: Archontológia 319. De valószínüleg volt még egy fia, mert 1694-ben Péter nevü nagyobbik fia tiltakozik, lásd KmProt XXX. 191v.

${ }^{419}$ SzT VI. 140.

${ }^{420}$ Jakab: Oklevéltár II. 333.

421 SzT VII. 47.

${ }^{422}$ MOL F25 (Miscellanea II.), $481^{\mathrm{v}}$.

${ }^{423}$ Kolozsvár város tanácsi jegyzőkönyve (1666-1696), az Egyetemi Könyvtár Kézirattárának őrizetében (BCU. Ms 990.) 80

${ }^{424}$ Trócsányi: Központi kormányzat 193.

${ }^{425}$ Szabó-Tonk: Egyetemjárás 261.
} 


\section{Szalárdi János 1664-1666}

Habár Szalárdi nevét mindenki ismeri, kevesen tudják, hogy tehetséges történetírónk életének utolsó szakasza Kolozsvárhoz és az itteni hiteleshelyi levéltárhoz köthető. Saját szavai szerint: „,a mi kegyelmes Urunk ő nagysaga, az Tanacs es deputatus urakkal mostani romlot nyomorodot allapotomban naponkint valo magam tengetesemre adtak rendeltek mind az fizető mestersegi kis beneficiumot, s az Conventbeli hivatalkat ahoz valo salariumocskaval" ${ }^{426}$ Pályájának korábbi állomásai nagy vonalakban ismertek, ${ }^{427}$ most csupán a konventi levéltár egyik őreként kifejtett tevékenységét részletezzük. A történetíró már korábban is látott el hiteleshelyi munkakört, Várad eleste előtt hosszú ideig az ottani káptalan egyik levélkeresője volt. ${ }^{428}$ Családjával együtt Kolozsvárra kerülve Szalárdi csakhamar tapasztalhatta, hogy a fizetőmesteri és a konventi fizetés eleve csekély, és még e kis juttatásokért is mindennapos harcot kell folytatnia a fejedelmi praefectussal vagy a vármegyei perceptorral. ${ }^{429}$ Mivel járandóságainak jelentős részét borban kapta, hamar meggyűlt a baja a borárulási privilégiumukat féltő kolozsváriakkal is.

Minden terhe, életviszonyai és a várossal való konfliktusai ellenére Szalárdi kivette részét a közéleti tevékenységből; már 1664 júliusában a kolozsvári református egyház kurátorai között találjuk. ${ }^{430}$ Körülményeihez képest munkáját a konventnél is lelkiismeretesen végezte. 1664 júniusában arról panaszkodik Teleki Mihálynak, hogy „De uram az Conventbeli levelek annyira egybe zavarodtak volt Szamosújvárról az fel s alá való hordozásban, igen sok bajunk van véllek" ${ }^{431}$ Bizonyára ez a helyzet ösztönözte arra, hogy a konventi levéltár rendezésére, a protocollumok mutatózására vállalkozzék. Ennek a munkának emlékei a jelenlegi XVIII. protocollum elejére bekötött mutatói. ${ }^{432}$ A 17 lap terjedelmű töredék a Tordai Péter levélkereső által vezetett két jegyzőkönyvnek, valamint Kászoni József egyik protocollumának elenchusait tartalmazza, és 1665 őszén készülhetett. ${ }^{433}$

\footnotetext{
${ }^{426}$ Jakab: Oklevéltár II. 387.

${ }^{427}$ Életútja összefoglalása a korábbi irodalom felsorolásával: Siralmas krónika 16-63.

${ }^{428}$ Feltehetően 1649-1660 között váradi káptalani levélkereső, lásd Bogdándi: A váradi hiteleshely 115.

${ }^{429}$ Szalárdi nyomorult állapotáról, kérelmeiről lásd Siralmas krónika 32-33. Saját beadványait és a fejedelem erre kelt válaszait vagy utasításait az általa vezetett jegyzőkönyvbe is bemásolta, lásd KmProt XXXVIII. $7^{\mathrm{v}}-8^{\mathrm{r}}, 41^{\mathrm{r}}-42^{\mathrm{v}}$.

${ }^{430}$ Siralmas krónika 33.

${ }^{431} \mathrm{KmJkv}$ I. 147. (68. sz. jegyzet).

${ }^{432} \mathrm{Km}$ Prot XVIII. elején.

${ }^{433}$ Erre utal Szalárdinak az egyik protocollum indexe után írott megjegyzése: „In ipso festo S. Michaelis Archangeli die 29. Septembris Anno 1665 Deo auxiliante finitum."
} 


\section{Virginás István 1666-tól}

Csupán egyetlen forrásban találtunk utalást arra, hogy életpályája egy szakaszában konventi requisitorként tevékenykedett: 1666 szeptemberében az országgyưlés Szalárdi János helyett őt rendelte „Kolosvárra fizető mesternek, perceptornak és káptalannak". ${ }^{434}$ Virginás is, akárcsak Szalárdi, bihari volt, karrierjét úgy tünik, a fejedelem kisebb kancelláriáján kezdte, írnokként. ${ }^{435}$ Bizonyára rátermettségének köszönhette, hogy 1639-ben már partiumi fiscalis director lett és e tisztségét 1653-ig biztosan viselte. ${ }^{436}$ Arról sajnos nincs adatunk, hogy meddig teljesített szolgálatot a konventi hiteleshelyen, tény az, hogy 1667-től már a fejedelmi tábla ülnöke, ${ }^{437}$ de ez - mint korábbi példákon láttuk - nem zárja ki annak lehetőségét, hogy ugyanakkor requisitor is maradt.

\section{Vicei István 1674-1694}

Kolozsvári gazdag református vallású patricíuscsalád sarja. ${ }^{438}$ Hosszú ideig, 1674-1694 között volt a kolozsmonostori konvent egyik requisitora. ${ }^{439}$ 1693-ban a kolozsvári református egyházközség kurátora.

\section{Pécsi András 1684}

Csak egyszer, 1684-ben említik kolozsmonostori levélkeresőként. ${ }^{440}$ Korábban talán a fejedelmi nagyobb kancellárián volt jegyző. ${ }^{441}$

\footnotetext{
${ }^{434}$ EOE XIV. 199.

${ }^{435}$ Trócsányi: Központi kormányzat 361.

${ }^{436}$ Uo. 361.; KmProt XXIX. 100v; MOL F1. XXIII. 16b, 70-71.; XXV. 28.; XXVII. 251b.

${ }^{437}$ Trócsányi: Központi kormányzat 361.

${ }^{438}$ A család egyik irodalompártoló tagjának, Vicei Máténak életútját Kiss András mutatta be, lásd Kiss: Források 189-194.

${ }^{439}$ Requisitori említései 1674: KmJkv II. 2653. sz. (jegyzetben); 1676: Jakó: Gyalu XCVIII (bevezető); 1680: Herepei: Adattár III. 546.; 1681: Erdélyi Református Egyházkerület Gyűjtőlevéltára, Kolozsvári Ref. Egyházközség Lt 2. II. 24. (Szász Anikó adata); 1692: F25 (Miscellanea II.), 597; 1694: B. Nagy Margit: Várak, kastélyok, udvarházak, ahogy a régiek látták. XVII-XVIII. századi erdélyi összeírások és leltárak. Bukarest, 1973. 371.

${ }^{440}$ Jakab: Oklevéltár II. 424-425.

${ }^{441}$ Trócsányi: Központi kormányzat 194. (1652-ben).
} 


\section{Laki Péter 1696-1703}

Kolozsvári polgár, a református eklézsia kurátora és számvevője, Pataki István professzor sógora. ${ }^{42} \mathrm{~A}$ kolozsmonostori hiteleshely egyik levélkeresője volt az 1690-es évektől kezdve. ${ }^{443}$ Egyházközsége számára gyakran teljesített megbízásokat, képviselte egyháza érdekeit az unitáriusokkal folytatott tárgyalásokon. Két kötettel gazdagította a református kollégium könyvtárát, az egyik nürnbergi ősnyomtatvány, a másik egy 1504-es velencei kiadású munkákat tartalmazó colligatum. Bibliofíliájának jellege arra vall, hogy levéltári munkája mind a régiségek megbecsülésére, mind azok közgyűjteményben való őrzésének fontosságára megtanította. ${ }^{444} 1703$ októberében hunyt el Kolozsváron. ${ }^{445}$

\section{Rákosi Péter 1696-1711}

1696-ban szerepel először kolozsmonostori requisitorként, ekkor Laki Péterrel együtt állította össze Kolozsvár kiváltságleveleinek jegyzékét. ${ }^{446}$ Ugyanakkor a város nótáriusi hivatalát is viselte. ${ }^{447}$ Levéltárosi feladatait lelkiismeretesen láthatta el, a Guberniummal való levélváltása arról tanúskodik, hogy - nem tudni, mekkora sikerrel - intézkedni próbált a levéltár megfelelő elhelyezése érdekében. ${ }^{448} 1711$-től „a jogban és stylus juridicus”-

\footnotetext{
${ }^{442}$ Herepei: Adattár III. 115. Református centumpater 1696-tól (Kolozsvár város tanácsi jegyzőkönyve, Ms 990, Kolozsvári Egyetemi Könyvtár Kézirattára).

${ }^{443}$ Levélkeresői említései 1696: Kiss: Források 21.; 1703: F25 (Miscellanea 1700-1760), 10v.

${ }^{444}$ Sipos: Kollégiumi könyvtár 57.

${ }^{445}$ Herepei János: A dési református iskola XVII. és XVIII. századbeli igazgatói és tanítói. Erdélyi Tudományos Füzetek 130., Kolozsvár, 1941. 11.

${ }^{446}$ Kiss: Források 21.

${ }^{447}$ 1701-ben városi jegyző, vö. Jakab: Oklevéltár II. 456.; kolozsvári nótárius 1704-ben, lásd KvNLt, Kolozsvár város 1t, fasc. II. 425/273. mikrofilmtekercs.

${ }^{448} 1703$ novemberében a Gubernium kérte, hogy Rákosi Péter requisitor tegyen jelentést arról, hogy Patikáriusné Jakab deákné vagy Verner Mihályné háza alkalmasabb a levelek conservatiójára. Vö. Beke: A kolozsmonostori konvent 645. sz. Rákosi Péter és Szentmihályi István levélkeresők válasza erre 1703. december 3-án kelt: „Edgy néhány ízben írtunk ennek elötte is Nagyságtoknak az Conventi levelek conservatiojára kívantató hely felöl, a mint hogy recommendaltunk is két alkalmatos helyeket, de el hisszük sok gondgyai között arra nem érkezett nagyságtok hogy ezeknek valamellyikére protectiot extrahalhasson, mostan immár az Bellicus Commissarius belé szálván az Verner Mihályéba maradt csak az Jakab patikáriusné háza, kiben is egy pattantyus káprál lakik, ha azért nagyságtok töb gondgyai között erre edgy protectionalist extrahalhatna az Guberalistól [?] ő excellentiajától nagyságtok mind minékünk [?] elei és fia, s közrendeinek is, igen nagy jót cselekednék, mert féltjük őket kártól, nem lévén semmi olly erős helyünk. Nagyságtok meltóságos válasszát alázatal várván és nagyságtokat az Úr Istenek oltalmába ajánlván maradunk" (ENMLt, Mike Sándor gyüjtemény, nr. 1814.).
} 
ban jártas Rákosi a Kancellária tanácsosa és registratora lett. ${ }^{449}$ Ebben a tisztségben érte a halál 1714-ben. ${ }^{450}$

${ }^{449}$ Trócsányi Zsolt: Habsburg-politika és Habsburg-kormányzat Erdélyben 1690-1740. Bp., 1988. 84., 110., 311., 326.

${ }^{450}$ Uo. 326. 


\section{A KOLOZSMONOSTORI KONVENT OKLEVÉLADÓ TEVÉKENYSÉGE A FEJEDELEMSÉG KORÁBAN}

A konvent személyzetének bemutatása után, a következőkben arra a kérdésre is választ kell adnunk, hogy miként folyt az oklevéladó tevékenység a kolozsmonostori konventnél és hogyan végezték munkájukat a levélkeresők.

Az újkori hiteleshelyek történetét feldolgozó Papp László az erdélyi requisitorok müködését tárgyaló (rövid) fejezetben lesújtó képet fest az erdélyi hiteleshelyek helyzetéről, s ezt annak tulajdonítja, hogy a hiteleshelyek kikerültek az egyházi felügyelet alól, a kinevezett világiak pedig nem végezték eléggé lelkiismeretesen munkájukat. ${ }^{451}$ Úgy véljük, hogy a Papp László által felvázolt kép hitelességét két elem határozza meg: az újkori hiteleshelyek monográfusa az erdélyi hiteleshelyek levéltárait nem tanulmányozta, ${ }^{452}$ értékítéleteit pedig érezhetően befolyásolta katolikus szemlélete. Ha átnézte volna ugyanis az erdélyi hiteleshelyek tekintélyes mennyiségü okleveles és protocollum-anyagát, az itteni levélkeresők müködésének termékeit, bizonyára más következtetésekre jut. A következőkben a levélkeresők oklevéladó tevékenységének bemutatásával arra fogunk törekedni, hogy árnyaljuk vagy helyesbítsük a Papp László által felvázolt képet, hangsúlyt fektetve azokra a változásokra, amelyek a hiteleshelyi oklevélkiadásban a szekularizációt, illetve az 1575. évi rendezést követően jelentkeztek.

Amint már bemutattuk, az 1575-ben kelt instrukció részletesen szabályozta a konvent és a káptalan belső és külső hiteleshelyi tevékenységét, nagyrészt a bevett gyakorlatot ültette újra életbe, de néhány ponton eltért attól (például bizonyíthatóan rövid időre eltiltotta privilégiumok kiállítását, az idézéseknél mellőzték a királyi emberek jelenlétét). Az oklevéladó

\footnotetext{
${ }^{451}$ Papp László: A hiteleshelyek 108-117.

${ }^{452}$ Uo. 5.
} 
tevékenységet alapvetően meghatározta a kinevezett személyzet világi jellege (a requisitorok a fejedelem fizetett „hivatalnokai”), létszáma (csak hárman vagy időnként csak ketten voltak), képzettsége és hozzáállása, illetőleg a hiteleshelyi működés helyszíne (Kolozsvár városa).

A konvent szekularizáció utáni történetét, valamint a zavartalan müködés „impedimentumait” Pálfi István requisitor fejedelemhez intézett 1655. évi beadványának fogalmazványa tárja elénk részletesen, s minthogy ez - a jelenlegi tudásunk szerint - a hiteleshely kora újkori történetének leghitelesebb forrása, a szöveget teljes egészében közöljük: „Kegyelmes urunk. Noha ennek előtte is, nem csak mi, de [a mi] predecessorink is sokszor requiraltak nagyságtokat ez conventi hivatalnak alkalmatlan állapottja felől, mindazáltal még eddig az dolog re infecta maradván kinszerítettünk most, az mostani articulusnak continentiaia szerint ex de necesse aláz[atosan] requiralni nagyságodat, és ha úgy kellenék az [...] mivel anny difficultasi vadnak ez hivatalban, hogy ha ezt nagyságtok nem remediallja, mi ez mellet így meg nem maradhatunk. Sok ugyan az difficultas kegyelmes uram, de mi ez mostani alkalmatossághoz képest csak ezekről akarok nagyságodat aláz[atosan] tudosítani.

[1.] Az Articulus tartása szerént három personaknak kell lenni itt is, mi pedig csak ketten lévén [...] nem expedialhatunk, mert eggykünknek távol létében az másik semmit sem recipialhat, sem pecsételhet, melyből nagy confusio jöt csak eddig is ki. Az én collegamnak ${ }^{453}$ penig Desen lévén felesége után háza, öröksége és minden majorsága [...] szüntelen vigyázni, pusztulni nem hagyhattja kárával, gyalázattjával. Én penig csak ez hivatalnak adván magamat és semmi egyéb külső dolgokban [?]. Én sosem egyedül semmi [...] sem recipialhatok sem expedial[hatok] [...] töltöm üdőmet [...] káros vagion.

[2.] Conservatoriumunk kegyelmes uram nincsen, az levelek miatt csak [...] hurczolljuk. Eddig az Cassaiak házánal vol[tak?], továb ők sem szenvedik, hova kell tenni? Eddigh is sok kár [?] lőtt az sok váldozás és hordozódás miatt, mivel lehetett hogy eggyitt is másult is el ne maradozzon benne, kiváltképpen az [...] holtok után. Magunk is ucza szerbe lakunk, ki együt ki másut, ha kinek [...] vagion velünk, ha eggikünköt hon talállja, az másikat nem [...], meg jöveteléig várakozzék, vagy re infecta el kell menni [...].

[3.] Az Articulusban fizetésünkről is vagyon emlékezet, de nekünk sem Articulus, sem az nagyságtok kegyelmes commissioia szerint való fizetést meg nem adják. Az tavaly és ez idei salariumunk [res?]tal Zamosuyvarat [...], néhány forint salariumunk jár avval veszünk búzát [...] és egyéb életünkre való táplálását. Adózás [...], gátlás, postaló adás, tizedelés és egyéb [...] vagyon, sine ullo discrimine et respectu [...], mellyen nagy fizetéssel

\footnotetext{
${ }^{453}$ Kászoni József deák (lásd a levélkeresők jegyzékét).
} 
kel végbe vinnünk [?]. Mikor fizetésünköt megadgyák is (salariumunk, ami eddig volt is, azt se adgyák meg az elmúlt eszt[endőre] Uyvarbol), az néhány forint pinzbeli salariumocskából kel venünk bort, búzát és életünkre való táplálást, ha mikor meg adgyák salariumonkat. Borunkat be nem bocsáttya [...] öt hat vedrével, nagy dispendiummal kel el veszteget[nünk], itt penig helyében mást egy vedrével vagy igen [...] más felével vehetünk mást.

[4.] Ugyan az Articulus szerént az leveleknek expeditioit úgy el fogtak tőllünk, hogy négy vagy öt rendbéli leveleknek expeditioján kívül nekünk többet nem engettek. Az legitima executio, mely ez hivatalnak propriuma tolláltatott, taxaia az leveleknek úgy diminualtatott, hogy juste labori non correspondet, holott csak egy réghi molyette levelet menny szemvesztéssel kell megírni.

Tőbb illy inconvenientiak sokak vadnak kegyelmes urunk, melyekből nagyságod kegyelmesen megértheti minémő hivatal legyen ez, és hogy Nagyságtok kegyelmes provisioja nélkül [...]. Hogy ha azért ez hivatal az réghi szent királyok, fejedelmeknek institutioiok szerint láttatik szükségesnek lenni, nagyságtok méltóztassék providealni felőlle, tertius collegat adván mellénk, rendelljen conventualis locust is, melyben absque preiudicio officii continualhassuk hivatalonkat: alioquin illy állapatban maradván, egy kapus drabantnál aláb valóknak láttatunk lenni, mellyet nem is supportalhatunk.

Mi kévánonk [?] uram, hogy ha úgy lehetne (accedalván ehez értelmes embereknek is ő értelmek) országul nagyságtok rendelne egy Conventualis locust, mellyet cum authoritate privilegialna is, hogy az kik requisitorok lennének laknának egy helyben és ott authoritative [?] (mint egyéb helyeken is) procedalnának, juxta officii exigentiam, debito modo. Erre penig egy alkalmatos helt nem találunk, mint Monostoron vagyon egy mángorló ház, ki nem sok épülettel igen alkalmatos lenne erre az szükségre. Ott mindeneket szép rendbe [...] ládákba helyheztetve, (Isten kitől ótalmazzon) háborúságnak idején, mind ládástól könyő volna behozni az várasba, mint ennek előtte is. Minekünk is job alkalmatosságunk lene az magunk táplálásában. Akár penig itt az várasban is szerezhetne az nemes ország illy szükségre nézve egy házat, az mely örökösön Conventualis locusnak depputaltathatik: [...] és successorink is voltaképpen procedalhattak és procedalhatnak hivatalunkban.

Ezekről méltoztassék nagyságtok kegyelmesen resolvalni magát és ugyan [...] tertius collegat is állatni, mert annélkül semi dolgunkban bátorsággal nem procedalhatunk. Ha penig úgy teczenék a nemes országnak, 


\section{talán csak transferalni kellene az Fejervari Captalanba ezeket az leveleket is, hogy sem mint így veszedelmeztenek" ${ }^{454}$}

${ }^{454} \mathrm{KmProt}$ XXXV. számozatlan lapokon levő fogalmazvány. Ugyanitt található egy kissé eltérő szöveg: „Csak ezt jelentjük nagyságotoknak, hogy mikor az háború üdőkben Colosmonostorrol ide Colosvarra hozták be volt az conventet, akkor mingyárt kezdet megváltozni, és leszállani is annak authoritassa [...]. Az melyből [?] az mostani sok inconvenientiak és impedimentumok crealtattak [?], akkor az várasi bírák, polgárok löttek requisitorokká, kiknél sok esztendeig [állottak az leve]lek [?]. Azután 1575. egy thordai egy terminuson rendelte az ország ezt, hogy három három capitularis es conventualis personakkal épülvén [?] az Captalani és Conventi hivatal, s az mostani pecsétet is akkor csinálták. Azolta bizonyos Conservatorium nem lévén, ki ki az Conventek közül házánál tartotta az leveleket és kinek kinek holta után, azt vötték az successorok kezekhez [...], én idemben azoknak maradéki adtak be nagy csomó leveleket az Conventbe [...]. Mindh az én üdömbenn is, az kik ezelöt 50. esztendövel voltak conventi hivatalban maradé[kik] nagy csomó leveleket adtak ide be, kik nálok maradtak. Illyen [...] mert ez üdő alatt itt nyomulván megh az levelek örzése [?], az req[uisitoro]k is ide kellet telepedniek, kik vagy házasságok útján [?], vagy pinzeken házokat [szereztek?], ott kellet lakni, ahun szerét tehette. Mint hogy [...] laktak, az várossi ember semmi distinctiót nem tevén köztök szinte [...] úgy saczoltatták adóval, gátlással, őrzéssel, postaló adással, tizedléssel és egyéb várossi tereh viseléssel, mint eggykit akárki közüllök örökséges embert absque ullo respectu, mely dolog [...]. Ezek felett az sem utolsó: hogy az mi borunk járna salariumunk [...] táplálására, be nem hozhattyuk, hanem nagy dispendiummal, öt hat vedrével, félszeg árron kell elvesztegetnünk, itt [?] egy vedrével kell mást vennünk helyében [...] és fizetésünkbeli pénzel, mely azon küvüll is csak fa vételünkre sem volna elégh [...]. Esztendöre percipialunk egy holnapig is plus minus alig érjük megh [...] impedimentumink is vadnak, kiket nem illik elő számlálnom [áthúzva]. Második impedimentum, salariumunk percipialása. Nem adván (kiváltképpen az mostani Szamos Uyvari tisztek), akármint sollicitalljuk, de egy időre való fizetésünket két s három esztendeig sem vehettjük kezünkben, mint hogy most is mind az elmúlt s mind ez jelen való esztendókre való fizetesünk mind hátra vagyon. Az réghi Conventeknek jövedelmek noha felette nagy volt, melyre mi [...] érdemesek nem vagyunk, mindazáltal ugyan azon officiumok terhe [...] fizetések deficialt [...], de az levelektől való taxa is annyra leszállott, hogy az mi fizetésünk is most [?] járna (mellyet sok rendbéli requisitiónkra, mind az... országh, s mind üdvözült urunk ő nagysága ugyan ex consilio... rendeltek vala) csak vesző félben vagyon, úgy hogy mellette [...] illy ratiora [...] honnét ő nagyságok rendeltek, úgymint Zamos Uyvarbol az ott való tiszt[ek] [...] való [...]. [Pénzen?] veszünk búzát, pénzen veszünk bort kevés pénzbeli fizetésünkből [...] computalljuk, napjára tíz pénz jut. Az elött az is fl. 60 volt, most fl. 33.33 [...] mert amit adnak is, mindennek az allyát és az szegényét adgyák, sine ullo respectu. Minden napra penig az bornak töltésétt [?] fel tudván [...] belőlle, egyéb helyeken penig ordinarie, kinek kinek házához küldik [...]. Én penig tudván ezt, qui aliquod munus subire cupit, prius suo cum [...] debet [...] qua res suscepti muneris ratio exigat, privata et [?] negligenda sunt ut publica [...] moveantur. Laborandum et ut aliis otiari liceat, vigilandum e ut aliis dormire liceat [...], egyéb sollicitudiomat hátra hagyván és csak ez állapatra fordítván életemnek utolsó végéig ebben akarván continualni. Harmadik impedimentum magunktól is származik. Mert eggyk lesz, hogy csak ketten vagyunk: az collegamnak penig Desen lévén háza, öröksége igen gyakorta megyen oda, és ott maga dolgaihoz látván, hol egy s hol két holnapig el mulat. Itt az officium vacalvan interea temporis csak egyedül vagyok, semmi fassiót nem recipialhatok, Tcz [?] 16. mely fölről eljönek az nemesek (kiváltképpen az szegény aszonynépek), és re infecta kel visza menniek, mely miatt már szinte disputusba vagyunk, káros is mind nekünk, s mind az nemességnek. És így is [?] accidentiank sohunét [?] nem lévén, igen súlyos semmi mellet nekem is itt [lak?] nom. Interim, ha mi olly Urunk dolga intervenial, én supportálom, ő pedig más dologban insudal s ugyan felveszi az fizetést. Úgy vagyon alter alterius onera [?] portate, ezt mondgya az szent [?], de viszont non obligabis os [?] bovi [...] est damnosum esse cuipiam officium suum. 
Mielőtt rátérnénk Pálfi keltezetlen szövegének bemutatására, szükségesnek véljük meghatározni a beadvány keletkezésének körülményeit. 1655. április 3-án hatalmas tüzvész pusztította el Kolozsvár mintegy háromnegyed részét, II. Rákóczi György emiatt kérhetett jelentést a városban őrzött levéltár állapotáról, és erre írhatta válaszként Pálfi az idézett szöveget. ${ }^{455}$ A másik tényező, amely Pálfit a beadvány megfogalmazására késztethette, az a „káptalanok” múködésének törvényi szabályozása volt, amely az Approbaták elfogadásával, 1653-ban történt meg. Erre valószínúleg azért került sor, mert az 1575. évi instrukciókban foglaltaktól a levélkeresők - részben kényszerből, részben vélhetően ügyfeleik „rábeszélésére” - gyakran eltértek, ami a törvény szövegéből és a konvent kiadványaiból egyaránt kikövetkeztethető. ${ }^{456}$

A panaszlevél megfogalmazója 1655-ben már szinte harminc éve szolgált a konventnél, ezért helyzetismeretét nem vonhatjuk kétségbe, azonban figyelembe kell vennünk e beadvány elsődleges céljait. Pálfi bizonyára őszintén aggódott a hiteleshelyi levéltár sorsáért, de az elsődleges szempont számára mégis elmaradt fizetése kézhezvétele, illetőleg egy új „collega” hivatalba állítása, saját tehermentesítése lehetett (tekintettel előrehaladott korára is). Egyértelmü, hogy a szövegíró által felvázolt kép csak keletkezésének időpontjára, a XVII. század közepére vonatkoztatható, de tagadhatatlan, hogy Pálfi lényegében helyesen látta a folyamatot: „mikor az háború üdőkben Colosmonostorról ide Colosvarra hozták be volt az conventet, akkor mingyárt kezdet megváltozni, és leszállani is annak authoritassa".

\footnotetext{
Negyedik impedimentum az Conservatoriumnak nem létele. Nyolczvan vagy kilenczven esztendőktől fogva csak periclitalvan az levelek, ki hinné, hogy kár nélkül lehetett az, kiváltképpen anny külömb külömb kéznél forogván: ha Conservatorium volna, abban annak rendi és módgya szerent (mint más Captalanokban), annak való örökös helt csinálván és sem tüztől nem féltvén, sem imide amoda való hordozodástól nem szaggatodván, mely nyugodalmas, mely bátorságos, mely szép dologh volna. Mostan penig mindenek rend nélkül lévén, amit egy nap kereséssel véghbe kellene vinni, egy hétig, sőt egy holnapig, vagy esztendeigh is, az egész leveleknek fel hányásával alig vihetjük végbe. Én sok ideig való munkámnak igen kevés hasznát látom, mivel csak egy requisitiokor is széllel hányattatnak az levelek, sőt az protocolumok közüll is néha az másik colleganál maradván, honn nem létében hozzá nem nyúlhatni, és így requisitionk hiában leszen." (A dőlt betűvel írott részek egy másik változat alapján végzett kiegészítések.)

${ }^{455} \mathrm{~A}$ tüzvészről lásd Kolozsvári emlékírók 412.

${ }^{456}$ AC 203: „,A mely káptalanokba pedig eddig más usussal éltenek, a szerént peragáltatott dolgok in vigore hagyattatnak; ez után valók a végezésekhez alkalmaztassanak." Az 1575-ös instrukció 1650-ben annotált példánya is említést tett a szabályok megszegéséről: „Ha a jó instructio nem observaltatik mind hogy eddig is sok esztendők alatt emlékezet sem volt felőle csak epitaphiumot írjunk az conservatoriumnak." Lásd Sunkó: A Gyulafehérvári Káptalan 86.
} 
Most nem térünk ki azokra az akadályozó tényezőkre, melyek a hiteleshelynek a városba való költöztetéséből eredtek, illetve a konvent levéltárára vonatkoznak (erről a későbbiekben lesz szó), csupán azokat vesszük számba, amelyek a belső és külső hiteleshelyi (oklevéladó) tevékenységet lényegében befolyásolni tudták. Ezen általános megállapítások után arra is sort kerítünk, hogy a konvent protocollumai és különböző levéltárakban fellelhető kiadványai alapján részletesen ismertessük az oklevéladó tevékenységet, lehetőséget teremtve a Pálfi szövegében foglaltakkal való öszszevetésre. Így talán a valósághoz közelebbi, árnyaltabb képet alkothatunk a konvent hiteleshelyi tevékenységéről.

A beadvány első pontja a requisitorok létszámából adódó akadályra vonatkozik: habár az Articulus (a káptalanokra vonatkozó articulus, az Approbatákban) ${ }^{457}$ végzése szerint hárman kellene lenniük, a konventnél a beadvány keltekor csak ketten voltak hivatalban (Kászoni és Pálfi), az egyik távollétében a másik requisitor ,,az egy procuratoria constitutión kívül" semmi fassiót nem vehetett fel, ez a helyzet pedig igen káros volt a nemességnek. ${ }^{458}$ Pálfi az Articulus rendelkezéseivel magyarázza a hatósági (fejedelmi) parancsra végzett executiók számának drasztikus csökkenését is: „Az legitima executio, mely ez hivatalnak propriuma, tollaltatott, taxája az leveleknek úgy diminualtatott, hogy juste labori non correspondet" (lásd a beadvány negyedik pontját). Az Approbaták káptalanokra vonatkozó cikkelyében azonban semmi nyomát nem találtuk annak, hogy megtiltották a hiteleshelyek végrehajtásait, sem annak, hogy a levélváltás díjait csökkentették. ${ }^{459} \mathrm{Az}$ viszont tény, hogy a későbbiekben sem a protocollumokban, sem máshol nem találtuk nyomát a konvent külső hiteleshelyi tevékenységének.

\section{1. A konvent előtt tett bevallások}

Ismeretes, hogy a hiteleshelyi tevékenység jelentős, esetünkben arányaiban nagyobbik része tanúskodás volt valamilyen jogügyletnél. A bevallások csoportjába sorolható bármilyen jogi természetú akaratnyilvánítás, melyet a felek vagy azok - többnyire ügyvédvalló levéllel rendelkező

\footnotetext{
${ }^{457}$ AC 202-203.

${ }^{458}$ Itt említjük meg, hogy 1649-ben a gyulafehérvári hiteleshelyen is csupán egy requisitor, Hercegszőlősi János volt hivatalban, lásd KmProt XXXIII. 27-28

${ }^{459}$ AC 203.: „Authoritások légyen minden legitima executiókra; mindazonáltal nem excludáltatván mellőlök és kivülöttök is, a dolognak mivoltához és eddig observáltatott usushoz képest egyéb legitimus executorok is”. Az oklevelek áráról: „,a leveleknek taxaiaban a régi limitátióhoz alkalmaztatnak". Ha azonban figyelembe vesszük a pénz folyamatos értékvesztését, akkor a levélkeresőknek valóban kevesebb jövedelmük származott a levelek taxájából (annál több a különféle ajándékokból).
} 
- törvényes képviselője nem hatósági utasításra, hanem saját akaratukból tettek, s melynek bizonyságára autentikus pecséttel ellátott oklevél kiállítását kérték. ${ }^{460} \mathrm{~A}$ következőkben nem ismételjük meg a bevallások ama jellemzőit, melyek a szekularizációt követően sem változtak, hanem az eljárásbeli változásokra fektetjük a hangsúlyt.

\section{A bevallások módja}

A középkorban a hiteleshely ügyfeleinek viszonylag egyszerü dolga volt e tekintetben, hiszen mindenki számára természetesnek számított, hogy a konventet a kolozsmonostori dombon álló apátsági épületben találja meg. A hiteleshely újjászervezését (1575) követően azonban megváltozott a helyzet, a „,konventet" a városba költöztették, és az oklevéladó tevékenység végzését három levélkeresőre bízták, akik Kolozsvár különböző pontjain laktak. Aki oklevelet akart kiállíttatni a konventtel, hármójuk közül kellett valamelyiket a szállásán felkeresnie, ahol a requisitor rövid jegyzetet készített az ügyről, az oklevél kiadására pedig szabályszerúen akkor kerülhetett sor, ha legalább ketten jelen voltak. A fassiók felvétele Gyulafehérváron is rendszerint a levélkeresők szállásán történt, erre utal I. Rákóczi György 1631. december 16-án kelt oklevele, melyben az akkor requisitorként tevékenykedő Bojti Gáspár, Kisfaludi András és Barsi Mihály városban levő házait - hivatalviselésük okán - fölmentette a beszállásolás terhe alól. ${ }^{41}$ Pálfi István fentebb idézett beadványa alapján biztosak lehetünk abban, hogy Kolozsváron sem volt állandó „,conventualis locus”, a bevallásokat tehát legtöbbször a requisitorok szállásán vették fel és foglalták írásba.

A XVII. század folyamán egyre gyakoribbá vált, hogy nem a bevallást tevő ügyfél kereste fel a hiteleshelyet, hanem a requisitorok kiszállását kérte (olykor hatósági-fejedelmi paranccsal) a bevallás helyszínére. Erre az ügyfelet kényszerítő körülmények (betegség, öregség, terhesség) is késztethették. A végrendeletek írásba foglalásakor rendszerint két levél-

\footnotetext{
${ }^{460}$ Bilkei: A zalavári és kapornaki konventek 98.

${ }^{461}$ I. Rákóczi György 1631. december 16-án kelt oklevele így jellemzi a levélkeresők gyulafehérvári házait: „,universe literae et literalia instrumenta, tam publicos Regni et Fisci, quam privatorum etiam regnicolarum usus et iurium firmitates concernentes, maiori ea parte apud sese existentes ad occurrentes repentinasque occasiones et necessitates ut plurimum in eisdem domibus vel hospitiis suis intertenere et conservare debeant ac alias etiam, quia publica ipsorum servitutis ratio perpetua scriptione et variarum literarum expeditionibus nihil propemodum intermisso labore continuare soleat, idque laboris alibi nullo penitus modo sed in suis confici et peragi debeat aedibus et hospitiis et denique quia varios fatentes, componentes, literasque rebus et iuribus suis necessarias ab ipsis extrahere volentes domi et in hospitio suo exaudire, fassiones recipere literas quascunque extradare soliti sint et conveniatur". Batthyaneum, A gyulafehérvári káptalan 1t,VII. doboz, 35.
} 
kereső szállt ki a helyszínre, más esetekben azonban csak egyikük vette fel a fassiót, az oklevelet pedig utólag, a collega beszámolója alapján állították ki. Az előbbi eljárásra számtalan példát találunk 1600 tájáról, amikor az országot háború és ennek következményeként járványok is sújtották. ${ }^{462}$ Azonban nem csak testamentumokat vettek fel ilyen módon, 1608-ban például Rákóczi Zsigmond parancsára két levélkereső ment a fejedelem kolozsvári szállására, hogy oklevelet szerkesszenek Telegdi Mártonnal kötött cseréjéről ${ }^{463} 1619$-ben pedig Ötvös András kolozsvári házához szálltak ki, ahol Károlyi Zsuzsanna fejedelemasszony akaratát rögzítették, aki familiárisának adományozta némely részjószágait. ${ }^{464}$ Máskor, a hiteleshelyek tekintélyének bizonyítékaként, maguk a fejedelmek járultak fassio-tétel végett a konvent elé, 1615 decemberében például Bethlen Gábor is személyesen tett bevallást a requisitorok elött. ${ }^{465} \mathrm{~A}$ protocollumokba másolt kivonatos bejegyzésekhez füzött jegyzetek esetenként arról is tájékoztatnak, hogy a fassio fölvétele pontosan hol is történt. 1606-ban például a kolozsvári jezsuiták rektora a kolostor kapuja előtt vonta vissza korábbi bevallását, ${ }^{466}$ 1628-ban Pálfi István requisitor Mikola János temetésekor

${ }^{462}$ 1600-ban Szentiványi György és Kövendi Mátyás vette fel kolozsvári Vicei Gáspár özvegyének, Pézeri Sárának végrendeletét, a következő évben Belső-Szolnok vármegye főispánjának, Tahi Istvánnak testamentumát Szentiványi és Kibédi János foglalták írásba (KmProt XV. $\left.35^{\mathrm{r}}-36^{\mathrm{v}}, 45^{\mathrm{r}}-45^{\mathrm{v}}\right)$.

${ }^{463} \mathrm{KmProt}$ XVI. $167^{\mathrm{r}}-167^{\mathrm{v}}$. A levélkeresők olykor nagy távolságokat tettek meg, hogy egyegy befolyásosabb ügyfél kérésének eleget tehessenek. 1619-ben például Belső-Szolnok vármegye ispánja, Haller Zsigmond rendelte őket a Kolozsvártól több mint 80 km távolságra levő bethleni várába, hogy feleségével kötött egyezségét írásba foglalják (KmProt XX. 113 ${ }^{\mathrm{r}}-114^{\mathrm{v}}$ ). Az ilyen kiszállások csak akkor számítottak törvényesnek, ha fejedelmi parancsra történtek, ezt támasztja alá Pálfi Istvánnak Wesselényi István zsibói officiálisához írott alábbi levele: „Kösz[önetem?] után adgyon Isten uramnak mind [?] sok jókat. Jól tudgya kegyelmed itt létébenn is mely akadály lőn az József deák collega Hadadba való kimenésében, én csodálom hogy most is [?] kegyelmed, vagy az úr ő nagysága csak egy szót is nem ír felölle. Minekünk uram az dolog igen [?] conscientionkba jár, fejedelem parancsolattja nélköl csak az váras határából se szoktunk kimeni fassiók recipialására, mert az ollyan az törvénbe nem szokot megh állani. Im mindazáltal az Úr és nagyságod tekintetiért, cum rei declaratione most [?] elküldöttük, ha condescendál, nem mi vétkünk. Akárcsak két nemes ember löt volna az coll[ega?] mellet, akkor kiknek rescriptioiokat vévén világosban expedialhattuk volna az levelet. Az levél váltságért is semmit nem küldött kegyelmed maga itt létébe, külömben beszél vala kegyelmed. Ha az Úr ő nagysága itthon volna, magának írtam volna, de az Urunk ő nagysága táblájától is érteniök kel az töb Captalanokkal eggyütt ez dolog felöl, mellyről ugyan solemniter protestálunk is. 11. Maii, Claudiopoli 1648. Steph[anus] Palfy mp" (KmProt XXXI. 115r).

${ }^{464} \mathrm{KmProt}$ XVIII. $81^{\mathrm{v}}$.

${ }^{465} \mathrm{KmProt} X X .1^{\mathrm{r}}-1^{\mathrm{v}}, 21^{\mathrm{r}}-21^{\mathrm{v}}$.

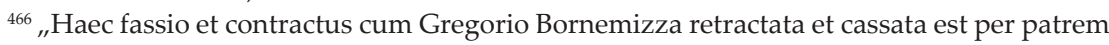
rectorem Joannem Argentum tempore exitus eorum ex hoc Regno, videlicet ante portam monasteriensem 12 die Novembris 1606. Coram me et Matthia Keovendy" (KmProt XVI. 129v). 
vett fel egy bevallást Szamosfalván, ${ }^{467}$ 1634-ben ugyanott foglaltak írásba egy ügyvédvallást, ${ }^{468} 1641$-ben a siralom éneklése közben pedig a kolozsmonostori templom a fassio-tétel helyszíne. ${ }^{469}$

1601-ben Kibédi Jánost és Kövendi Mátyást küldték ki „in conspectum dominorum procerum magnatum et universitatis Regni nobilium hic Colosvarini, in comitiis eorum generalibus ad vigesimam primam diem huius mensis Januarii anno currente indictis et celebratis", akik visszatérve jelentették, hogy a fötéri kisebbik templomban (,in templo minori theatrali”) fölvették a rendek nyugtáját arról, hogy Gyerőfi János fizetőmesteri hivatalában hűségesen járt el és a kifizetésekkel elszámolt. ${ }^{40}$ Ismeretes, hogy már a szekularizáció előtt élt az a gyakorlat, hogy a konvent kiküldte néhány tagját a nemesi congregatiókra a fassiók felvétele érdekében. 1368-ban például maga az apát szerepelt kiküldöttként a custos és a cantor társaságában „monostorunk rendtartása és ősi jogszokása szerint". ${ }^{471}$ Úgy tünik, hogy a korábbi hagyományt folytatva a requisitorok a fejedelemség korában is részt vettek az országgyúléseken, ahol - részben tehermentesítve a fejedelmi kancelláriát - írásba foglalták az előttük tett bevallásokat. ${ }^{472}$ Arról is van adatunk, hogy a levélkeresők írásbeli munkáját a városban tartott terminusok (törvénykezési szakaszok) alkalmával is fokozottan igénybe vették, így történt ez 1639-ben "tempore octavalis termini nobilium dominorum in partibus regni Hungariae Transilvaniae, in civitate Colosvar celebrati", midőn „,in hospitio [...] illustrissimi principalis celsitudini, domus videlicet honestae domine Anna Kowaz [?] presentes ibidem illustrissimo spectabili et magnifico domino Georgio Rakoczi de Felseo Vadaz, aliisque plurimis dominis et proceribus Transsylvanensis in eodem palatio", Wesselényi István a fejedelem kérésére felszabadította egy jobbágyát, aki az udvarban szolgált allovászmesterként. ${ }^{473}$

\footnotetext{
${ }^{467}, 1628$. feria sexta proxima post domenicam Sexagesimae generosus d. Michael Banfi Lossonczy de Zentelke, in possessione Zamosfalwa, ac in ipso templo, tempore videlicet funerationis generosi pueri Joanni, filii generosi quondam domini Joannis Mikola de Zamosfalwa dicta [?], ex generosa domina Susanna Kowaczioczi, alias consorte sua progeniti personaliter coram nobis existentis fassus est [...]" (KmProt XXIII. 35v).

${ }^{468} \mathrm{KmProt}$ XXVI. $76^{\mathrm{r}}$.

${ }^{469}$ "In templo Colosmonostrensi tempore cantandi lamentationum protestatio celebrata est" (KmProt XXVII. 75r).

${ }^{470} \mathrm{KmProt} X V .50^{\mathrm{v}}-51^{\mathrm{r}}$.

${ }^{471}$ Sipos: Kolozsmonostor 40.

472 1635-ben például Pécsi János requisitor egyedül állít ki oklevelet: „absentibus dominis collegis meis ac ob certas causas Albae Iuliae in comitiis dominorum regnicolarum existentis" (KmProt XXIX. $\left.47^{\mathrm{v}}-48^{\mathrm{r}}\right)$.

${ }^{473} \mathrm{KmProt}$ XXIX. 103 $-104^{\mathrm{r}}$.
} 
A kiszállásos fassio-felvétel másik módozata volt, hogy a konventi kiküldött a fejedelmi intézkedés végrehajtása érdekében kiszállásokon járván elfogadott magánosoktól bevallásokat, melyekről aztán a hiteleshelyen pecsétes oklevél született. Ismeretes, hogy a középkorban a leleszi konvent embere végzett ilyenféle „kiszállási melléktevékenységet”, de arról nem volt tudomásunk, hogy ez a gyakorlat a kolozsmonostori konvent fejedelemség kori tevékenységében is kimutatható. ${ }^{44}$ 1638-ban a kolozsmonostori requisitorok oklevelükkel bizonyították, hogy rátóti néhai Gyulafi Sámuel özvegyének, Bethlen Annának kérésére, illetőleg a fejedelem parancsára kiszállt közülük Tordai Péter és Pálfi István a Doboka vármegyei Őrmező birtokra, hogy fölvegyék az asszony ügyvédvallását. Visszatértükben megálltak Tamásfalvi Imre Tamásfalván (Kolozs vm) épült udvarházánál, ahol „mellékesen” megállapították az ifjú Tamásfalvi Miklós életkorát. ${ }^{475}$ Pálfi István 1647-ben is fassiókat vett fel, amikor a fejedelem Fehér megyébe küldte előbb Keresd, majd Orlát és Keresztyénsziget határainak bejárásához. ${ }^{476}$ Ezekben az esetekben a kiállított oklevél szövegében utaltak arra, hogy a bevallást valamely executio végrehajtása alkalmával vették fel.

A bevallásokat az ügyfelek általában élőszóban tették, de már a XVI. században előfordult, hogy előzőleg anyanyelven írásba foglalták vagy foglaltatták a jogügyletet, és úgy járultak a hiteleshely elé. ${ }^{477}$ Ez az eljárás a magyar nyelvű írásbeliség terjedésével, a következő század folyamán egyre gyakoribbá vált, azzal a különbséggel, hogy a beadott szöveget már nem fordították le latinra, hanem a konvent egyszerűen saját autentikus pecsétjével megerősített oklevelébe foglalta a bemutatott iratot. Így jár-

${ }^{474}$ Vö. Borsa Iván: A királyi ember és a hiteleshelyi küldött melléktevékenysége Leleszen. In: Emlékkönyv Jakó Zsigmond születésének nyolcvanadik évfordulójára. Kolozsvár, 1996. 101-108. AXVI. század közepétől ezek a helyszíni feljegyzések gyakran magyar nyelven készültek, vö. Kertész Balázs: Az Országos Széchényi Könyvtár MNY 64. jelzetü nyelvemlékéről (Egy hiteleshelyi eljárás során készített feljegyzés). In: Levéltári Közlemények LXXVII (2006). 1. sz. 91-103.

${ }^{475} \mathrm{KmProt}$ XXIX. $81^{\mathrm{v}}$.

${ }^{476}$ Miután Orlát és Keresztyénsziget határait megállapította, a fejedelem Kisenyedre küldte Pálfit végrehajtani (ad aliam expeditionem), ahol írásba foglalta egy udvarház eladását (KmProt XXXI. 127 $\left.{ }^{\mathrm{r}}-128^{\mathrm{r}}\right)$, Keresden pedig megállapította Macskási Mihály és Bethlen Katalin gyermekeinek életkorát (KmProt XXXI. 133r).

${ }_{477}$ Magyarországon is kezdett elterjedni ez a gyakorlat, vö. Papp László: A hiteles helyek 74-75. Rődi Cseh Istvánnak 1507-ben kelt, saját kezűleg írott, magyar nyelvű végrendelete is azért kerülhetett a kolozsmonostori konvent levéltárába, mert annak megfogalmazója „végső akaratáról teljesen közhitelü, latin nyelvű hiteleshelyi oklevelet kívánt kiállíttatni", lévén, hogy ekkor még a jogi írásbeliségben a magyar csak kisegítő szerepet játszott. Lásd Jakó Zsigmond: Rődi Cseh István, az anyanyelvü írásbeliség egyik erdélyi úttörője. In: Írás, könyv, értelmiség. Tanulmányok Erdély történelméhez. Bukarest, 1976. 40. 1554-ből példánk is van arra, hogy Barcsai Borbála végrendeletét anyanyelvü írásban adják be a gyulafehérvári káptalanhoz, melyet az latinra lefordítva és hiteles oklevelébe foglalva bocsát ki. Lásd Vass Miklós: Székely oklevelek a XVI. századból. In: Történelmi Tár 1910. 125. 
tak el például 1590. május 12-én, amikor a kolozsmonostori requisitorok tanúsították, hogy a betegsége miatt eléjük járulni képtelen Brini László szamosújvári praefectus kérésére Szentiványi György és Balásfi Ambrus levélkeresők kiszálltak egy kolozsvári házhoz, ahol Brini magyar nyelven, írásban végrendelkezett (,„coram eisdem collegis nostris condidisset testamentum in scriptis, nativo sermone") ${ }^{478} \mathrm{~A}$ testamentumokat előzőleg a végrendelkező foglalta írásba, illetőleg a végrendelkezésnél jelen levő tanúk valamelyike vagy maguk a requisitorok vetették papírra magyarul, a jobb érthetőség kedvéért („,nativo sermone perspicuitatis gratia”). Szinte mindig ezzel magyarázzák a korábban anyanyelven írásba foglalt rendelkezés közhitelű oklevélbe foglalását (és nem latinra fordítását). Úgy tưnk, hogy a végrendeletek esetében különösen törekedtek a „szöveghüségre”, arra, hogy a testamentumot tevő végső akaratát tartalmazó, az örökösök által is érthető magyar nyelvü szövegen semmit ne változtassanak.

Írásbeli fassio-tétel nem csupán végrendeletek esetében történt. Már 1561. augusztus 9-én előfordult, hogy a váradelőhegyi káptalan oklevelébe írásban megkötött, magyar nyelvú egyezséget foglaltak, ${ }^{479}$ de ezt az eljárást Istványi igen ritka esetnek minősítette. A kolozsmonostori konventnél a középkori gyakorlatból nem ismerünk hasonló esetet, de 1600-ban Mihály havaselvi vajda és császári helytartó familiárisa, Földesi Gáspár, illetve Erdő Miklós leánya, Fruzsina már anyanyelvű írásban tették fassiójukat, ${ }^{480}$ és ugyanebben az évben Perneszi Miklós is saját kezűleg írott bevallásával jelent meg a requisitorok előtt. ${ }^{481}$ A szerződések, egyezségek és más jogi ügyletek írásban való beadásának gyakorlata a XVII. század folyamán egyre gyakoribb jelenség, és ezt vélhetően ugyanaz a „majoris perspicuitatis et evidentia" magyarázza. Egyre kevesebben értették a latin nyelvű szöveget, az anyanyelven megfogalmazott pedig immár közérthetőnek számított a társadalom egyre tágabb rétegei számára.

Ritkábbak azok az esetek, amelyekben a hiteleshely ügyfele levélben küldte el bevallását valamelyik requisitornak, és arról konventi pecséttel megerősített oklevél kiállítását kérte. ${ }^{482}$ 1643-ban Szalánci Krisztina asz-

\footnotetext{
${ }^{478} \mathrm{KmProt}$ X. $11^{\mathrm{v}}$.

${ }^{479}$ Történelmi Tár 1887. 358-363. Idézi Istványi: A magyarnyelvủ írásbeliség 40.

${ }^{480} \mathrm{KmProt} X \mathrm{XV} .12^{\mathrm{r}}-13^{\mathrm{r}}$.

${ }^{481}$ A szöveget a következő formulákkal foglalták oklevelükbe: „eadem in scriptis nativo sermone manu sua propria exaratis nobis exhibuit petens nos debita cum instantia ut eadem de verbo ad verbum litteris nostris inserere vellemus quorum tenor et verbalis continentia sic habebat [...]”. A végén: „Praemissa itaque universa in scriptis exhibita presentibus literis de verbo ad verbum inserta idem Nicolaus Pernezy fassus coram nobis ad eademque se obligavit inviolabiliter observando" (KmProt XV. 16r $\left.-17^{\mathrm{r}}\right)$.

${ }^{482}$ Még ennél is gyérebben fordulhatott elő, hogy az oklevél igénylője a requisitorok nevében fogalmazta meg saját bevallását, majd ezt elküldte a levélkeresőkhöz, akiknek semmi más dolguk nem maradt, mint az irat konventi pecséttel való megerősítése. Kovacsóczi
} 
szony a kolozsvári Híd utcában lakó Péter deák konventi requisitort azzal a kéréssel kereste meg, hogy egy tordai ház eladásáról misszilisében tett bevallását „írja be az káptalanba, ha kegyelmedet az nevezet Szabo György uram megh talállja felölle" ${ }^{483}$ A protocollumba foglalt eredeti levél alatti bejegyzésből arról is tudomást szerzünk, hogy az asszony szolgája mikor jelent meg a levéllel, és a „bevallást” mikor vették fel: „1643 Feria tertia proxima post festum gloriosae Resur. d. nostri Jesu Christi exhibitae, presentatae per introscriptum Georgium Szabo Thordensis, exhibitae et approbatae receptae. Requisitor Colosmonostrensis". ${ }^{484}$ Olykor maga a fejedelem is lényegében szabálytalanul nyert oklevelet a konventtől azáltal, hogy például 1651-ben misszilisben küldte el bevallását, melynek értelmében a kendilónai jószágot és nemesi udvarházat, 17800 Ft erejéig, halála esetére Kassai István árváinak inskribálta. ${ }^{485}$

Az írásban tett fassiók sorában arra is találtunk példát, hogy a bevallást tevő levelet küldött a hiteleshelyre, majd utóbb személyesen is megjelent a levélkeresők előtt, és az írásában foglaltakat megerősítette. Vélhetően ugyanekkor nyert a konventtől szabályosan kiállított oklevelet is. Ilyen módon járt el például 1629-ben a dobokai ispán, Gyulafi Sámuel, aki saját kezével írott magyar nyelvű tiltakozását juttatta el a requisitorokhoz, akik levelét utóbb protocollumukba foglalták úgy, hogy a szöveg alatt feljegyezték a személyesen történt bevallás tényét és időpontját is. ${ }^{486}$ Szintén az írásban tett bevallások különleges, vélhetően ritkán előforduló eseteként jegyezhetjük a konvent 1638. október 19-én kelt oklevelét, amely szerint a requisitorok előtt megjelent Kemény János Fehér vármegyei főispán, illetve farnasi Géczi György özvegye, Bercsényi Zsuzsanna, és kijelentették, hogy az általuk bemutatott összehajtogatott és lepecsételt iratba foglaltakat (melynek tartalma a levélkeresők előtt ismeretlen maradt) minden részletében betartják. ${ }^{487}$

István kancellár protocollumba foglalt bevallása szabályos konventi kiadványnak tűnik, de Pálfi István requisitor érdemesnek vélte megjegyezni, hogy a szöveg „mind éppen szegény cancellarius Kovaczoczi István írasa, az stylus is magáé" (KmProt XXIV. 34).

${ }^{483} \mathrm{KmProt} X X V .73^{v}$.

${ }^{484} \mathrm{Uo}$

${ }^{485}$ II. Rákóczi György bevallását kisebb és titkos pecsétjével megerősített levelében küldte a konventhez, lásd KmProt XXXIV. 61 $1^{\mathrm{v}}-62^{\mathrm{r}}$.

${ }^{486}$ Gyulafi protocollumba foglalt tiltakozása alatt Tordai Péter levélkereső kezével: „Anno Domini 1629, feria quinta proxima ante festum B. Demetrii martiris, spectabilis ac magnificus dominus Samuel Giulafi de Ratotth, comes comitatus Dobocensis, coram nobis personaliter existentis, modo intrascripto oretenus retractavit, revocavit, reclamavit et contradixit, cum solemni protestatione" (KmProt XXV. $8^{\mathrm{r}-8^{\mathrm{v}}}$ ).

${ }^{487}$ A requisitorok a következőképpen fogalmazták oklevelüket: „sponte et libere exhibuerunt nobis et praesentaverunt unas quasdam literas complicatas et clausas, sigillisque ambarum partium propriis in cera hispanica, partim rubra, partim nigra ab extra in dorso impressive communitas et corroboratas promittendo sibi mutuo et invicem ac obstringendo 
Mint említettük, a jogi ügyletről személyesen és megbízott által is nyilatkozni lehetett, a megbízottat rendszerint valamelyik hiteleshelyen kiállított ügyvédvalló levéllel hatalmazták fel. Ezt az oklevelet olykor egyszerü megbízólevél is helyettesíthette, amelyben az ügyfél arról értesítette a konventet, hogy az előtte megjelenő személy az ő megbízásából teszi bevallását. ${ }^{488} \mathrm{~A}$ tekintélyesebb nemesek servitoraikat küldték a konventhez írásbeli ügyeik elintézésére, és olykor írásban is utasításokkal látták el őket, nehogy tévesen állíttassák ki az oklevelet. Kemény János például minden részletre kiterjedő instrukcióval látta el konventhez küldött emberét, akinek érkezéséről Pálfi István káptalannak is üzent. ${ }^{489}$

Minden előzetes egyeztetés ellenére, minthogy a requisitorokat megfigyeléseink szerint Bethlen Gábor uralkodásától kezdve alkalmanként, majd a Rákócziak alatt rendszeresen a fejedelmi birtok- és államigazgatás szolgálatába állították, egyre több alkalommal megtörténhetett, hogy a requisitorok közül többen is „in negotiis principis” távol voltak, így nem lévén teljes létszámú a konvent, az ügyvédvalláson kívül más oklevelet szabály szerint nem adhattak. Felmerül tehát a kérdés, hogy miképpen

sese eaedem ambae partes coram nobis universa et singula in eisdem clausis et modo quo supra obsignatis litteris contenta, scriptoque intrinsecus denotata et expressa, nobis tamen incognita et non specificata, tam in toto quam in parte sanctae et inviolabiliter in perpetuum utrinque observaturos" (Kemény cs csombordi lt a KvNLt őrizetében, nr. 831.).

${ }^{488}$ Igy tett például 1641-ben Bethlen István, Máramaros vármegye örökös ispánja, aki az alábbi levelet küldte a requisitorokhoz: „Adom tuttára mindeneknek az kiknek illik ez levelemnek rendiben, nevezet szerint az nemes Colosmonostori Káptalan uraimnak, hogy bocsyátottam be ez levelem megh adó Szegedi Zsigmond ne[v]ü iffjú legény szolgámat kegyelmetekhez néműnemü bizonyos és szükséghes dolgom véghet. Kegyelmeteket azért akarom felölle tudósíttani, hogy valamit én nevemmel kegyelmeteknek fogh mondani, kegyelmetek ez dologhban pro rata et ferma tartcsya, kérem is kegyelmeteket, hogy az mely contradictioról való levelet kell készítteni, ne késlellje kegyelmetek annak el készíttését [...]". F25 (Miscellanea II.), f. 258.

${ }^{489} \mathrm{Az}$ 1640-es évek végén kelt emlékeztető feljegyzés eredetijét a requisitorok protocollumukba foglalták (KmProt XXXI. 90r):

„Memorialle

1. Tholdi Istókot kolosvari káptalan eleiben vivén revidealni kell aetassat és revisionalt extrahalni arról

2. Az gyermek immár lévén tizennégy esztendős valljonn curatornak engemett ha akar, mert én tovább nem tutorkodom. Ha curatornak vall, cum plenipotentia kell lenni és curatoriat extrahalni. Constituálljon procuratorokat az gyermek mind Erdelyeket, s mind Partiumbeliekett

3. Eddig való tutorsagról quietalljon az káptalan uraim előtt és absolutusnak pronuntialljon, fatealvan eddig való gondviselésemmel mint volt contentus

4. Ha pedig nem akarna fatealni az gyermek [...] protestalljanak és renuncialljanak az tutelanak

Ez dolgokról izentem volt András deák uramtól Palfi uramnak, ő kegyelmét kell requiralniuk, az leveleknek pedig ki váltására és kézhez vételére András deák uram maga mennyen be. Azon leveleket pedig első alkalmatosságal hogy kezemhez küldgye kolosvari bíró uramat kell requiralni. Be kell csinálni és pecsétleni az levelekett." 
jártak el ilyen esetekben. Az bizonyos, hogy alkalmanként instrukciójukat megszegve állították ki az igényelt oklevelet, erre maga az Approbatákban levő tiltás a bizonyíték. A Kolozsváron maradt levélkereső ilyenkor úgy tett, mintha a testület teljes létszámmal működne, annak ellenére, hogy egyedül fogalmazta és pecsételte meg a kiadványt. Ennél gyakrabban alkalmazták azt a megoldást, hogy az írásba foglalandó ügyről signaturát vett fel az egyik káptalan, majd arról akkor bocsátották ki az oklevelet, amikor a testület mindegyik tagja jelen volt. Erre az eljárásra az oklevélben általában az alábbiak szerint utaltak: „Nos requisitores etc [....] memoriae commendamus tenore praesentium significantes quibus expedit universis quod egregius Petrus Thorday requisitor et collega noster conventualis personali sua astantia, ad singularem prudenti et circumspecti Petri Razman centumviri Colosvariensis instantiam et petitionem de rebus et fassione infrascriptis conscientiose et viva voce coram nobis retulit eo modo quod in anno domini millessimo sexcentessimo tricesimo secundo, immediate praeterito, feria sexta proxima post festum Annunciationis B. Mariae virginis, tunc elapsum prefatus Petrus Razman tutor et curator orphanorum et liberorum circumspecti quondam Joannis Bek Colosvariensis nominibus et in personis eorum ab una, ac nobilem alter Petrus Eormeny alias Lazar vel Czizmadia, pro semetipso, partibus ab alia, absentibus eo tempore nobis, coram se et certis quibusdam adhibitis nobilibus personis et arbitris [...] coram ipsis fassus fuisset tali modo [...]. In cuius quidem dicti requisitoris et collegae nostri conventualis fidedigne relationis testimonium presentes litteras nostras sigillo conventus nostri usitato roboratas [...] extradando duximus et concedendo" ${ }^{490} \mathrm{~A}$ városban levő requisitor az elébe járuló ügyfél bevallásáról felvett signaturáját többnyire saját jegyzőkönyvébe vezette be, és ennek az egyre gyakrabban magyar nyelven írott szövegnek a megfogalmazásakor utalt arra, hogy kollégái miért nem lehettek jelen. ${ }^{491}$

\footnotetext{
${ }^{490} \mathrm{KmProt}$ XXIX. 1 $1^{\mathrm{r}}-2^{\mathrm{r}}$. Ennek a formulának kissé különböző változata 1642-ből: „Nos etc. Damus etc. quod nobilis Stephanus Palffi de Colosvar frater et collega noster conventualis coram nobis personaliter constitutus fideliter et conscientiose nobis retulit in hunc modum: qualiter ano superiore millesimo sexcentesimo trigesimo septimo feria sexta proxima post dominicam primam Adventus, nobis duobus in negotio illustrissimi domini domini regni Transilvaniae principis etc. domini nobis gratiosissimus absentibus nobilis domina [...] coram ipso personaliter constituta [...] tum viva sua voce tum etiam in scriptis coram prenominato collega nostro in specie exhibitis et presentatis talem fecisset atque celebrasset fassionem pariter et contractum prout fecit et celebravit ungarico idiomate sit subsequentem [...], quam quidem praenominatae dominae Margarethae Fwzy fassionem modo et tenore quibus supra, coram antelato collega nostro factam et celebratam, ad fidedignam eiusdem collegae nostri relationem sub sigillo nostro conventuali et authentico fideliter et conscientiose extradando duximus et concedendo. Datum [...]" (KmProt XXXII. $\left.3^{\mathrm{v}}-4^{\mathrm{r}}\right)$.

${ }^{491}$ 1634-ben például Pálfi István egyedül veszi fel Nagy, másként Havaselvi István bevallását, minthogy ",aliis collegis uno quidem ad receptionem testium quorundam versus Abrugybanya, Offenbanya et Keoreosbanya ac Topanffalva, altero quidem ad lustrationem quorun-
} 
A bevallások írásba foglalásának változatai között még arra is találtunk példát, hogy a requisitorok távollétében (nobis requisitoribus in negotio Ill. Domini regni Transilvaniae principis absentibus) két kolozsvári polgár foglalt írásba egy végrendeletet, majd erről - a polgárok jelentése alapján - a konvent utóbb saját pecsétjével megerősített oklevelet adott ki. ${ }^{492} \mathrm{Ez}$ a példa is arra vall, hogy a levélkeresők - részben kényszerből - meglehetősen rugalmasan kezelték müködési szabályzatuk rendelkezéseit. Az Approbaták végzései e téren komoly változást hozhattak, hiszen a törvényben szigorúan szabályozták az oklevéladást, és adataink arra utalnak, hogy a levélkeresők - legalább egy ideig - követték is az intézkedéseket. 1655-ben a konvent oklevelével bizonyította, hogy elébe járult Kapi György, aki „exhibuit nobis et presentavit literas quasdam anno proxime preterito 1654 . feria etc [...] hic in conventum coram altero nostrum personaliter constitutus, propriis manibus suis scriptas et exoratas in conventumque ad reservandam datas protestatorias pariter et contradictorias, nativa lingva [!] confectas, quas ex eo quod per absentiam alterius collegae nostri tunc ipsae litterae legitime expediri extradarique, vigore Articulorum D. Regnicolarum superinde editas, per solum collegam nequivissent, easdem igitur ipsos literas nunc videlicet die datarum presentium, coram nobis utriusque denuo et ex novo fatendas et celebrandas omniaque et singula in eisdem contenta roborandas et ratificandas duxisset" ${ }^{493}$

A konventi testület hiteleshelyi működésének fentebb említett hiányosságai miatt, a létszámhiány következményeként az oklevél cselekménye (actio) - az a jogi jelentőségü tény, melyet az irat bizonyít -, illetve a kiállítás között olykor hosszabb idő is eltelhetett. ${ }^{494} \mathrm{~A}$ hiteleshelyet felkereső ügyfelek már a XVII. század első felétől kezdve, de inkább Bethlen Gábor uralkodásától számítva egyre gyakrabban kényszerültek arra, hogy a bevallásukat újból megerősítsék, midőn „integer lezen az Conventus”, hiszen többször előfordult, hogy „,az collega uraink, eggyk Urunknál ő felségénel, másik legitima executioban" volt. ${ }^{495}$ Ilyen esetekben a bevallásról jegyzetet vettek fel a protocollumban, és ennek alapján állították ki az oklevelet rendszerint mindhárom requisitor jelenlétében. Így az oklevél cselek-

\footnotetext{
dam militum sub certorum capitaneorum [...] militantium constituturum, ex commissione Illustr. D. D. principi [...]" távol vannak (KmProt XXVII. 53v).

${ }^{492}$ KmProt XXXII. $36^{\text {r. }}$.

${ }^{493} \mathrm{KmProt} X X X V .23^{\mathrm{v}}$.

${ }^{494} \mathrm{Az}$ actum és datum közötti különbségekről lásd Szentpétery: Oklevéltan 23-24. Vö. Süttő Szilárd: Datum és actum késő Anjou-kori uralkodói okleveleinkben. In: Studia Miskolcinensia 3. Történelmi tanulmányok. Miskolc, 1999. Digitalizált változat: http://mek.niif.hu/02000/02097/ html/sutto.htm

${ }^{495}$ KmProt XXIII. 106 v.
} 
ménye és kiállítása között olykor jelentős időbeli eltérések adódtak, még akkor is, ha a bevalló maga a fejedelem vagy annak képviselője volt.. ${ }^{496}$

Vélhetően szintén a létszámhiány és a fokozottabb leterheltség vezethetett az oklevéladó tevékenységben jelentkező ama hiányosságokhoz, melyekről a konvent egyik ügyfelének, Désfalvai Horvát Györgynek Pálfi István levélkeresőhöz intézett levele emlékezik meg: „Kegyelmed uram emlékezhetik reá, hogy az én bátyámmal, vitézlő Desffalvi Kükeolleo vármegyebeli Horvát Istvánnal az kegyelmed házához menvén az elmúlt esztendőben ő kegyelme valla engemet plenipotentiariusnak minden dolgokból, mely kegyelmed előt való dologh vala, ugyan az kegyelmetek várassában lakó emberséges ember előt, ki üdvözült kegyelmes urunknak deákja vala [...] revocaltunk is mindketten ugyan akkor, melyről meg is adtam ugyan akkor mentén d. 25, az többi restal, kit megh kültem kegyelmednek. Kegyelmed megh egy historiat is hoza elő, hogy csiak egy czédulára irata kegyelmed fel, hogy az szél elfúja néha az ollyan aprólék cziédulákot s oda lészen. Kegyelmedet uram az Istenért is igen kérem, hogy aszt az két levelet el készítse, ez levelem megh adó embertől küldgye megh kegyelmed, kit mígh élek szolgálhassak megh kegyelmednek" ${ }^{497}$ A levélben említett zavarok, egy-egy fölvett signatura elkavarodása amiatt is előfordulhatott, mivel a requisitorok nem egy épületben, hanem külön-külön, mindegyik saját házánál tevékenykedett, ezért is kényszerültek arra, hogy a hiteleshelyi tevékenység „menetéről” egymást levélben értesítsék, adatokat kérjenek a kiállítandó oklevélről, a bevallást tevő személyérôl. ${ }^{498}$

Mint a fenti példák is mutatják, az előttük tett bevallásokról a requisitorok rövid jegyzetet (signaturát) vagy valamivel hosszabb fogalmazványt készítettek, hogy az oklevél szerkesztéséhez szükséges adatok megőrződ-

${ }^{496} 1649$. április 20-án a kolozsmonostori levélkeresők egyike Szamosújváron veszi fel a fejedelmet képviselő udvarmester, Orbán Ferenc bevallását, amelyről szinte egy teljes év elteltével, 1650. március 25-én állítanak ki oklevelet (KmProt XXXII. 38 ${ }^{\mathrm{r}}$ ).

${ }^{497}$ 1649. október 3. F 25 (Miscellanea II.), f. 355.

${ }^{498} 1635$ körül vélhetően Tordai Péter jelenti Pálfi Istvánnak, „,hogy itt benn vala Vitez György uram, némünemü protestatiokat celebrala, kegyelmed is jelen vala, nem tudom mellykünk írta fel, ha kegyelmednél volna az jedzés expedialni kellene, mert sollicitallia igen serio. Nállam vagyon egy, azt én meghírom, de az másik nem jutt eszembe. Bene valeat" (KmProt XXVIII. $72^{v}$ ). 1638 táján szintén Tordai kért tanácsot Pécsi János kollégájától bizonyos oklevelek kiállítása ügyében: „Zentmarthoni uram ment vala kegyelmedhez valami revocatio dolga felől, azt mondá, hogy kegyelmeddel beszéllet, de dubitalok benne. Az revocatio és contradictio megh volt előttem, az felesége Zabo Anna nevével, mivel az elzállagosításkor in capillis volt, menyegzeje után egy héttel volt elötte, kegyelmedet azt mondgyák, honn nem találták akkor, úgy ítélem, hogy kiadhatni, mivel az mégh nem törvény, csiak thörvény úttja. Zilwasi Boldizsárné asszonyom képében is lőn tegnap egy protestatio az Vingarthi jószágh állapattja felől, az ember elsieti [?]. Ha kegyelmed az székel regestumot beadgya, s ő nagysága az nállam való felől emlékezik, megh mondhattja, hogy én is holnap felviszem az nállam valót. Az határ dolga felőll is, ha kévántatik, kegyelmed referalhattja mint volt, Finta [?] uram is bár eligazítaná az defalcatat [?] [...]." (KmProt XXVII. 64v utáni cédula). 
jenek. ${ }^{499}$ Ezeket a jegyzeteket vagy külön cédulákra írták, vagy egyből a protocollumokba fogalmazták, a XVII. századtól kezdődően egyre inkább magyar nyelven. Az okleveleket ezen fogalmazványok alapján állították ki, de előbb (vélhetően mindhárom, de legalább két requisitor jelenlétében) felolvasták és az előforduló hibákat javították. ${ }^{500}$ Ezt követően kerülhetett sor a megírt és újból átvizsgált tisztázat megpecsételésére.

\section{A bevallások tartalmi csoportosítása}

Az alábbiakban tartalmuk szerint kisebb csoportokba tömörítve tárgyaljuk a konvent kiadványait. Részletesebben csupán azokat a bevallásokat ismertetjük, amelyek a szekularizációt követő hiteleshelyi múködés jellegzetesebb termékei, nem térünk ki azokra, melyek a középkorra és a kora újkorra egyaránt jellemzőek. Célunk ezen a téren is a különbségek, változások szemléltetése. Arra is kísérletet teszünk, hogy a felsorolt oklevéltípusok megjelenésére és gyakoriságára magyarázatot adjunk.

\section{Jobbágyfelszabadítások}

A szekularizáció előtt vezetett konventi jegyzőkönyvek kivonataiban összesen hat alkalommal van szó a jobbágyi terhek alól való felszabadításról, és ezen bejegyzések mindegyike a XVI. században kelt. ${ }^{501}$ Ehhez képest az 1576-tól vezetett protocollumokba egyre nagyobb számban vezettek be manumissiókat, olyannyira, hogy a XVII. század némely időszakában az ilyen típusú bejegyzések vannak túlsúlyban. Ez egyértelmúen jelzi a növekvő társadalmi mobilitást, Kolozsvár fokozott vonzerejét, mellyel a tágabb környékbeli jobbágyság értékesebb elemeit magához vonta és egyúttal a parasztság kezén levő tőkét is beszippantotta. ${ }^{502}$

A jobbágyfelszabadításoknak lényegében két típusát különböztethetjük meg. Az elsőben a jobbágy és földesura közvetlenül érintkezik, megváltása díját a jobbágy vélhetően saját vagyonából törleszti, többnyire részben készpénzben, részben terményben vagy szolgáltatásban. 1582

\footnotetext{
${ }^{499}$ Leleszen, de bizonyára Kolozsmonostoron is az oklevélkiadás munkájának fázisai a középkorban is ugyanezek voltak, lásd Kumorovitz: A leleszi konvent 11.

${ }^{500}$ Olykor ezeket a fogalmazványokat egyszerüen bekötötték a jegyzőkönyvekbe, amiről a szövegük mellett olvasható feljegyzések is tanúskodnak: „Extradatae Francisco Haczoki et in protocolum inserendae” (KmProt XVI. 40 ), „Protocolo inscribendae” (KmProt XVI. 36 ).

${ }^{501} \mathrm{KmJkv}$ II. 3573., 3642., 3854., 5010., 5265., 5273. sz.

${ }^{502}$ A városok már a középkorban is nagy vonzerőt jelentettek a feltörekvő jobbágyok számára, vö. Szabó István: Jobbágyok-parasztok. Értekezések a magyar parasztság történetéből. Sajtó alá rend. és a bevez. írta Für Lajos. Bp., 1976. 179-189. A manumissiókról bővebben lásd Varga János: Jobbágyrendszer a magyarországi feudalizmus kései századaiban 1556-1767. Bp., 1969. 226-227.
} 
februárjában például Hacaki György azért menti fel Kolozsváron lakó ősi jobbágyát és családját a jobbágyi terhek alól, mivel az 35 magyar forintot fizetett, egy szőnyeget adott és kerekes mesteremberként egy szekeret is gyártott számára. ${ }^{503}$ 1609-ben Túri Mihály feleségének szökött jobbágya 150 Ft-tal, illetve ökrökkel és juhokkal fizette meg szabadságát. ${ }^{504}$

A manumissiók nagyobb részénél azonban a jobbágy közvetítők révén nyerte el szabadságát, akik vagy a város tekintélyesebb polgárai voltak és valószínűleg valamilyen kapcsolatban álltak a szökevénnyel, vagy azt szolgálatukba akarták szegődtetni. 1616-ban például az utóbb katolikus vikáriusnak kinevezett Fejérdi Márton szepesi kanonok Katalin nevű húga és gyermekei felszabadítását érte el úgy, hogy a földesúrnak 100 Ft-ot fizetett, aki viszont cserében az asszonynak adományozta a kalotaszegi Türében levő házukat, és kötelezte magát, hogy az iktatáskor nem tesz ellentmondást. ${ }^{505} \mathrm{~A}$ manumissiókban megjelenő közvetítők olykor tekintélyes összegek törlesztéséért vállaltak kezességet, 1612-ben például debreceni „Teoreosdi" Mihály nemes 1000 forint kifizetésére kötelezte magát Kamuthi Balázs Tóth Gergely nevü jobbágyának felszabadításáért. ${ }^{506}$ Sokkal ritkábban történhetett meg, hogy térítésmentesen szabadították fel a jobbágyot, sükösdi Teremi György özvegye is csupán azért mentesíti 1631-ben Varga Jánost, mert az a kolozsvári iskolában szász collaboratorként múködött. ${ }^{507}$ Ritkán szerezhetünk arról tudomást, hogy a közbenjárónak milyen érdeke füződött a jobbágy felszabadításához: egy 1625-ben kelt oklevél szerint Petki Ferenc Kolozsvárra szökött jobbágyáról Rozsás István senatorral kötött egyezséget, melynek értelmében a polgár 32 forintot fizetett a jobbágy felszabadításáért, aki viszont kötelezte magát, hogy ezentúl Rozsásnak dolgozik. ${ }^{508}$ Vélhetően a közvetítők révén létrejött manumissiók zömében a szabadságát elnyerő jobbágy polgári közbenjáróit illető tartozását hasonló módon, szolgaként törlesztette.

\footnotetext{
${ }^{503}$ KmProt VII. $128^{\mathrm{r}}-128^{\mathrm{v}}$.

${ }^{504} \mathrm{KmProt}$ XIII. $83^{\mathrm{r}}$.

${ }^{505}$ KmProt XVII. 181 ${ }^{\text {r-182 }}$. Bethlen Gábor 1618-ban nevezte ki katolikus vikáriusnak Fejérdi Mártont, aki lényegében püspöki joghatósággal kormányozhatta az erdélyi egyházmegyét. Lásd Bíró Vencel: Bethlen Gábor és az erdélyi katolicizmus. In: Ódon Erdély. Bp., 2004. (elektronikus változata: http://mek.oszk.hu/04900/04920/index.phtml)

${ }^{506} \mathrm{KmProt}$ XVI. 155ㄴ -156r. Megjegyzendő, hogy az oklevélben Tóth Gergely nobilisként szerepel.

${ }^{507} \mathrm{KmProt}$ XXVIII. $46^{\mathrm{r}}$.

${ }^{508} \mathrm{KmProt}$ XXII. 32v: ,JJacobus Berladi antedicto Stephano Rosas [...] in vinearum suarum cultura, aliisque decentis negotiis fideliter et cum fructu (accepto [...] laboris sui condigno salario) inservire debeat."
} 


\section{Jobbágyul kötések}

Valamivel ritkábban fordulnak elő a konvent kiadványai között olyan oklevelek, melyek szabad emberek jobbágyul kötését regisztrálták (a középkori jegyzőkönyvekben erre nem is találtunk példát). 1636-ban Kolozsvár senatusának kérésére a requisitorok a tanácsházhoz mentek, ahol írásba foglalták a Magyarországról elszármazott Polgár Ambrus szabados bevallását arról, hogy az megtapasztalva a patrónus nélküli élet bizonytalanságát, a város jobbágyának kötötte magát, cserében pedig három nagy köböl búzát és 32 forintot kapott. ${ }^{509}$ Néhány évvel korábban, 1629-ben $40 \mathrm{Ft}$ és két köböl búza "támogatást" kapott egy Szilveszter János nevű széki ember, aki szintén Kolozsvár jobbágya lett Apahidán. ${ }^{510}$ Minden jel arra utal, hogy a földesúr és a jobbágy közötti viszony mindkét fél számára - természetesen különböző mértékben - kötelezettségeket jelentett: a jobbágy elsősorban védelmet nyert patrónusától, az úr pedig hűséges szolgálatot és egy benépesített jobbágytelket. Egy 1620 májusában kelt bejegyzés magyar nyelven fejezi ki ezt a szerződéses viszonyt: „mivel mostan ő szabad személy volna és senkihez jobbágiul köteles nem volna, mindazáltal nem akarna bizonyos patronus nélkül lenni, akihez az ő szükségének idején folyamodhatnék és nyavalyájában, bántásiban patrociniumot várhatna [...] szabad akarattja szerent, juramento mediante coram nobis prestito örökös jobbágyul köté magát feleségestől, gyermekestől”, amiért a patrónus Jónás deák Magyarnádason egy házat, két ökröt szekerestől, egy fejős tehenet és két köbölnyi szántóföldet adott, kikötve, hogy szökés esetén elfogathatja és úgy cselekedhet vele „mint afféle hüti hagyot emberrel”. ${ }^{511}$ Szintén a szerződéses kapcsolatra példa azon 1621-es egyezség (lényegében kollektív jobbágyul kötés), amely Ajtonyi Jakab tordai kamarás és a Kolozs vármegyében levő Oláhkarára telepedett jobbágyai között jött létre. ${ }^{512}$ Ajtonyi a birtokán megszállt jobbágyokat és az ezután letelepedőket két évre felmentette a jobbágyi szolgáltatások teljesítése alól, ezen időszak elteltével havonta egy hetet kell szolgálniuk, aki ezt elmulasztaná, egy forinton marad. Ha viszont a földesúr nem tartaná be a szerződés feltételeit, jobbágyai szabadon távozhatnak. A telepesek ingóságait haláluk után gyermekeik öröklik, azok hiányában pedig atyafiaik. A fentiek bemutatásával korántsem az volt a szándékunk, hogy idealizáljuk a jobbágy-földesúr viszonyt, csupán arra próbáltunk utalni, hogy a protocollumokban és máshol fellelhető jobbágyul kötések, szerződések összegyűjtése és elemzése bizonyá-

\footnotetext{
${ }^{509}$ KmProt XXVIII. 101 $101^{\mathrm{v}}$.

${ }^{510} \mathrm{KmProt}$ XXIII. 108v.

${ }^{511} \mathrm{KmProt}$ XVIII. 150v.

${ }^{512} \mathrm{KmProt}$ XVIII. $110^{\mathrm{r}}-110^{\mathrm{v}}$.
} 
ra árnyalná és pontosítaná a kora újkori társadalmi viszonyokról alkotott meglehetősen sematikus képünket.

A konvent a szabadok és a jobbágyok közötti átmeneti kategóriára, a szabadosokra vonatkozóan is állított ki okleveleket, amelyek a libertinusként teljesítendő szolgáltatásokat taglalják. ${ }^{513}$ Hasonló jellegű szerződéseket már a szekularizáció előtt is kötöttek a hiteleshelyen, de vélhetően jóval ritkábban. ${ }^{514} \mathrm{~A}$ libertinus és birtokos közötti viszony részleteiről kimerítően tájékoztat egy sor - többnyire magyar nyelvü - szerződés, melyek közül egy 1629-ben keltet idézünk: „Karandy Miklós Baroldságban, Biharvarmegieben, Nagypatakon lakó, ki régen jött el hazájából, köté magátt örökös szabadosul Balintfy Kristóf uramnak, ez meghírtt conditiok alat: tudniillik, hogy Balintffi uram Korpadon, Colosvarmegieben adgyon ház hellyet neki és az megh éppítésében segíttséggel legyen pénzel florenus 2 . Item kétt köböl búzáwal. Annakfelette dézmát ne adgyon, hadban ne mennyen, hanem mint szabados úgy szolgálljon jámborul. Korpadra [?] jobbágyokat szállítsyon, az adóban az ő kegyelme több jobbágytt segítsye, mégh az jobbágyok megh szaporodhatnak. Köntösre minden kétt esztendőre egy egy végh abát adgyon neki Balintfi uram. Az mely jobbágyokat Korpadra [?] szállitt, azoknak kétt esztendeigh szabadságok legyen, csyak három három hetett szolgálljanak az két esztendőnek mindenikében. Az két esztendő le telvén, két héten magoknak, harmadikon Balintfi uramnak szolgáljanak. Karandi Miklóst penigh Balintfi uram Gieori Márton uramnak extra viam juris ki nem adgya, hanem vagy törvényel, vagy compositioval megh ótalmazza, ha penigh törvénnyel megh nyerné Gieori Márton uram, az mit Balintfi uram neki adott és ad, azokat Karandi Miklósnak vissza vitelekor ne tartózzék kiadni, ha penigh Balintfi uram jobbággyá akarná tenni Karandi Miklóst, és nem szabadosságban tartaná, tehát Miklós elmehessen, ha meghbizonyosodik. Sz[ent] György napigh penigh Balintfi uram nem erőlteti Karandy Miklóst, hogy inkáb éppülhessen. Kezét be adá Karandy Miklós ez dolgoknak igazán való megh állására". ${ }^{515}$

\footnotetext{
${ }^{513}$ A szabadosok a robottól és más urasági terhektől időlegesen vagy véglegesen mentesített jobbágyok voltak. Lásd Úriszék 1042-1043. Erre a kategóriára vonatkozóan bővebben lásd Csapodi Csaba: Szabadosok (libertini) 1514-1848. In: Századok LXXIV (1940). 405-426.

${ }^{514} \mathrm{KmJkv}$ II. 5378. sz.

${ }^{515} \mathrm{KmProt}$ XXIII. 112r $-112^{\mathrm{v}}$. 1637-ben a Lengyelországból származó Lengyel János és családja Born Lászlót földesurának ismeri el és kötelezi magát, hogy Magyargorbóra költözik és ott libertinusként szolgál: „more libertinali et non colonicali” (KmProt XXXI. 44r-44v); 1633-ban Székely Márton a Szt. Erzsébet ispotály szabadosának köti magát (KmProt XXVI. 73²).
} 


\section{Kezeslevelek}

Szintén többnyire jobbágyokra vonatkoznak a kezeslevelek. Közülük némelyek a röghöz kötött jobbágy szökését próbálták megakadályozni, illetve biztosítékul szolgálhattak arra az esetre, ha mégis elköltözött. 1627-ben például három jobbágy vállalt kezességet a kolozsváriak felsőfüldi jobbágyáért, kikötve: „ha penigh elszöknék, és az kezesek elő nem állathatnák, és kézben nem hozhatnák Vogha Simont, tehát az florenos 200, az váras és az ispánok az kezeseken mind falun, mezőn, várason és akármely hellyen, exclusis omnibus juris remediis, vigore saltem presentium, egy vice ispánnal, avagy szolgabíróval meghvehessen". ${ }^{516}$ A kezességvállalásokon belül elkülöníthetők azok az egyezségek, amelyek a kolozsvári Toronyban börtönben sínylődő foglyokról szólnak. A város törvénye szerint az, aki elfogatott valakit, köteles volt élelemmel tartani, ezért a rabok nem sokáig maradtak a börtön lakói, hanem az ítélethirdetésig kezességen szabadulhattak. ${ }^{517} 1627$ májusában a város felsőfüldi jobbágya előtt nyitották meg a fogház ajtaját, mivel többen is kezességet vállaltak érte. Ez utóbbiakra hárult a fogoly 160 forintot kitevő homagiumának kifizetése is, arra az esetre, ha az ítélethozatalra nem tudnák elóállítani. ${ }^{518}$

Újabb alcsoportként különíthetők el azok a kezeslevelek, melyeknek szereplői nemesek. 1620-ban például a gyakran hatalmaskodó Pápai Balázs szabadult ki a gyalui vár börtönéből, mivel több nemes - fővesztés terhe alatt - kezességet vállalt érte. ${ }^{519}$ Sajnos nem ismerjük annak az ügynek a hátterét, melynek folyamán Bethlen Gábor fejedelem szamosújvári börtönébe vetette kolozsvári Géczi Istvánt, aki onnan csak tekintélyes nemesek - mások mellett Bethlen Ferenc és Basa Tamás - közbenjárására, 10000 forint kezesség terhe alatt szabadulhatott. ${ }^{520}$ Teljesen más jellegú ama 1630-ban kelt kezesség, amely szerint tehetős kolozsvári polgárok arra az esetre vállaltak kötelezettséget, hogy ha Bethlen István vagy örökösei nem törlesztenék a Bethlen Gábor és első felesége, Károlyi Zsuzsanna részére készülő márvány síremlék árát, akkor 9000 lengyel forintig terjedően (a teljes összeg fele része!) kifizetik a tartozást a sírkőkészítő olasz mesternek vagy halála esetén testvérének. ${ }^{521}$

\footnotetext{
${ }^{516}$ KmProt XXIII. 19r.

${ }^{517}$ A kolozsvári börtönről és lakóiról bővebben lásd Kiss: Források 70-83.

${ }^{518}$ KmProt XXII. 114 ${ }^{\mathrm{r}}-114^{\mathrm{v}}$.

${ }^{519} \mathrm{KmProt} X X .174^{\mathrm{v}}-175^{\mathrm{r}}$. Pápai Balázs vármegyei ügyeiről lásd Dáné Veronka: „Az őnagysága széki így deliberála". Torda vármegye fejedelemségkori bírósági gyakorlata. Erdélyi Tudományos Füzetek 259. Debrecen-Kolozsvár, 2006. 120., 145-146.

${ }^{520} \mathrm{KmProt} X X .183^{\mathrm{v}}$.

${ }^{521} \mathrm{KmProt}$ XXIV. $51^{\mathrm{v}}-52^{\mathrm{r}}$.
} 


\section{Nemesi kiváltságokról való lemondás}

Kolozsvár városa az erdélyi nemesekre is komoly vonzerőt gyakorolt, akik gyakran nem csak tezaurizált vagyonukat, hanem önmagukat is a biztonságot nyújtó falak közé próbálták „menekíteni”. A vármegyei nemesek városi házszerzései már a XVI. század folyamán komoly problémát jelentettek a városi önkormányzat számára, minthogy ezek adómentességükre hivatkozva megpróbálták elkerülni a kötelező terhek és szolgáltatások teljesítését. ${ }^{522} \mathrm{Ha}$ a város többnyire nem is tudta megakadályozni a nemes birtokszerzését, azt minden esetben elérte, hogy a vármegyei nemes esküben vállalta városi jussa utáni kötelezettségei teljesítését és lemondott nemesi előjogainak kolozsvári érvényesítéséről. Ezen eskütétel helyszíne a XVI. század második felétól a fejedelemség korának végéig a konvent volt, ezt igazolja az 1656 szeptemberében kelt tanácsi határozat is, amely újra kihangsúlyozta, hogy a régi törvény értelmében „aki a városba be akar jönni, a káptalannál nemességéről mondjon le, azután magát a város közé hittel kebeleztesse be". ${ }^{523} \mathrm{Az}$ eskütételekről kiállított oklevelek teljes szövegü másolatai, illetve kivonatai jelentős számban maradtak fenn a konvent protocollumaiban. Hogy konkrétan mire vállalt kötelezettséget a városba költöző nemes, arról - mások mellett - egy 1620-ban kelt eskütétel tájékoztat. Ekkor gyulafehérvári Jezerniczky János fejedelmi adószámvevő György nevü fia jelent meg a requisitorok elött, aki mivel Kolozsvárra akart házasodni és költözni, Ajtonyi Jakab deák és ifjabb Filstich Péter által arra kérte a város elöljáróságát, hogy fogadják kebelükbe és írják be a lakosok közé (,,acceptare et in numerum reliquorum incolarum et inhabitatorum huius civitatis Coloswar recipere et ascribere dignarentur"). A város vezetősége viszont csak akkor volt hajlandó őt befogadni, ha nemesi előjogairól lemond, ezért arra kötelezte magát, hogy a város határain belül kiváltságaival nem él, hanem a helyi törvényeknek veti alá magát. ${ }^{524}$ Kolozsvár tanácsa (senatusa) többnyire két esküdt polgárt bízott meg a város-

\footnotetext{
${ }^{522}$ A kérdésről bővebben lásd Pakó László: Városi polgár-vármegyei nemes? Nemesek ingatlanszerzése Kolozsváron a fejedelemség korában. In: A reneszánsz Kolozsvár. Kolozsvár, 2008. 222-255.

${ }^{523}$ Uo. 239.

${ }^{524}$ „Idem Georgius Jezerniczky posthabita et deposita sua nobilitari praerogativa ad hoc se obstrinxit et obligavit nostri in conspectu, ut ipse nullo unquam tempore in hac civitate Colosvar et intra territorium eiusdem civitatis, contra privilegia et libertates antefatae civitatis Coloswar, adversus incolas et inhabitatores praenarratae civitatis Colosvar jure suae nobilitatis utitur, sed libertati et prerogativae nobilitatis suae renunciandum duxisset, prout renunciavit in praesentia modo premisso. Praeterea privilegia huius civitatis Colosvar, omnibusque et singulis eiusdem consuetudinibus, legibus et oneribus se submittere ac civitatensibus se ipsum conformare atque mandatis dominorum judicum et senatorum toties dictae civitatis Colosvar obedire et obtemperare velle asservit et affirmavit coram nobis" (KmProt XVIII. 101 r).
} 
ban házat szerző nemes konvent elé vitelével, hogy szükség esetén ők is tanúsíthassák az eskü letételét. ${ }^{525}$ Nemesi kiváltságokról való lemondásra a konvent középkori jegyzőkönyveiben nem találtunk példát, a szekularizáció előtti időszakban a város vélhetően még nem vonzotta annyira a nemeseket, mint a XVI. század második felétől kezdődő fénykorában.

\section{Végrendeletek}

Az előbbiekben már utaltunk arra, hogy Kolozsvár városa mekkora vonzerővel bírt az erdélyi társadalom különböző rétegei számára, de a véglegesen beköltözők mellett nagy számban voltak olyanok is, akik csupán átmeneti szállásnak vagy éppen menedéknek tekintették a várost. A tágabb környék birtokossága a válságos, háborús években a város falai között talált menedékre, és ezek az időszakok sokukat késztették arra, hogy végakaratukat is írásba foglaltassák az itt müködő hiteleshellyel. ${ }^{526}$ Különösen sok testamentumot tartalmaznak a Basta rémuralma idején vezetett jegyzőkönyvek, és a végrendelkezés indokaként szinte mindegyik szövegben a bizonytalan, pestises időket hozták fel. ${ }^{527}$ A levélkeresők 1602-ben éppen egy pestisben fekvő asszony, Hesdáti Erzsébet végakaratát vették fel kolozsvári szállásán úgy, hogy a korábban magyar nyelven leírt rendelkezést az asszony előtt felolvasták, majd a konvent pecsétjével megerősített oklevelükbe foglalták. ${ }^{528} \mathrm{Ez}$ volt a végrendeletek írásban való rögzítésének egyik módja. Máskor a testamentumtevő már képtelen volt személyesen a konvent elé járulni, ilyenkor két levélkereső kereste fel bevallását meghallgatni. Gyakran akkor is magyar nyelvü a testamentum és csak a keret latin, ha a requisitorok fogalmazták a szöveget. Bornemisza Boldizsár esetében, de máskor is, ezt az eljárást a jobb érthetőséggel magyarázták („,hoc ut sequitur ordine manifestasset, nativo sermone perspicuitatis gratia per nos

\footnotetext{
${ }^{525}$ 1631-ben kelt kivonatos bejegyzés szerint: „,circumspectus Michael Nyreo et alter Michael Fenessy jurati cives et dispensatores civitatis Colosvar ex commissione amplissimi senatus adduxerent secum nobilem Michaelem litteratum Beoleoni alias Cerjek [?], magulatorem Colosiensem, qui nobilitarem suam praerogativam deponeret, jurisditioni judicis et senatus Colosvariensis se subdidit" (KmProt XXVI. 13v). Vö. KmProt XXIII. 62 ${ }^{\mathrm{r}}$.

${ }^{526} \mathrm{~A}$ végrendeletekre vonatkozó irodalom összefoglalását lásd Lupescuné Makó Mária: Erdélyi késő középkori nemesi végrendeletek tárgytörténeti tanulságai. In: Emlékkönyv Kiss András születésének nyolcvanadik évfordulójára. Kolozsvár, 2003. 317-322.

${ }^{527}$ 1603-ban Várfalvi János végrendeletében az indok megfogalmazása: „considerans vitae humanae inconstantiam et periculosae huius nostrae tempestatis statum deplorandum" (KmProt XV. 80v-81 $)$.

${ }^{528} \mathrm{KmProt} \mathrm{XV}$. 93v . A végrendeletek esetében bevett gyakorlat volt az, hogy a konvent már korábban anyanyelven megfogalmazott szöveget foglalt saját kiadványába, lásd még: KmProt XV. $106^{\mathrm{r}}-107^{\mathrm{r}}$; KmProt XVI. 91 ${ }^{\mathrm{r}}-91^{\mathrm{v}}$.
} 
conscriptam") ${ }^{529}$ Bornemisza végrendelete a helyszín miatt is külön figyelmet érdemel, a tanácsúr szállása ugyanis a kolozsvári Borbély, másként Auner Márton házában volt, betegségében vélhetően ez utóbbi kezelhette. A fájdalmak által gyötört tehetősebb nemesek gyakran bízták magukat a városban működő borbélyok kezére, az 1580-as években például Rozsás János barbitonsor többször szerepelt végrendeletek tanújaként, vagy - orvosként teljesített szolgálatai jutalmául - kedvezményezettjeként. ${ }^{530}$

Az örökösödés a kolozsvári polgárság körében főképp a szokásjogot követte. ${ }^{531} \mathrm{Az}$ 1603-ban törvényben is lefektetett örökösödési jog a végrendelkezés jogát csak a szerzett javakra tartja fenn, kimondva, hogy „,valakinek őstől maradtat ne hagyjanak az, kit ő nem keresett", mert az ilyen rendelkezésnek semmi ereje nem lehet. ${ }^{532}$ Ezért az örökhagyó kolozsvári polgár többnyire csak akkor tekintette szükségesnek az írásban történő akaratnyilvánítást, amikor nagyobb szerzett vagyonnal rendelkezett és azt nem vagy nem csak törvényes örököseinek szánta. A tárnoki városokban a végrendelkezéseket a városi hatóságok felügyelték, és a XV. századra bevett gyakorlat volt a testamentumok városi könyvekbe való bejegyzése. ${ }^{533}$ Ezzel szemben Kolozsváron a városi könyvekben nem találhatók végrendeletek, arra viszont van adat, hogy 1568-ban a város saját, nagyobb pecsétjével ellátott testamentumot adott ki. ${ }^{53} \mathrm{~A}$ kolozsvári polgár végrendelkezését már a szekularizáció előtt is a város joghatóságától független intézménnyel, a konventtel foglaltatta írásba, és ez a gyakorlat a hiteleshely Kolozsváron való újjászervezése után ismét felelevenedett. Már 1580-ból találtunk példát arra, hogy Szegedi Anna polgárasszony férjének, Nagy Gáspárnak hagyta a debreceni Cegléd utcában levő ház őt illető harmadrészét, illetve a kolozsvári Farkas utcában épült ingatlanát és minden ingóságát. ${ }^{535} \mathrm{Az}$ örökségből kizárt rokonság természetesen nem hagyta jóvá Szegedi Anna végakaratát, testamentuma ellen 1583-ban tett tiltást Szabó Mátyás, Katalin nevü felesége és fiai nevében. ${ }^{536}$ Fejérvári József 1599-ben kelt rendel-

\footnotetext{
${ }^{529} \mathrm{KmProt}$ XVII. $10^{\mathrm{r}}-11^{\mathrm{r}}$. A középkori jegyzőkönyvekben magyar nyelven megfogalmazott végrendeletet nem találtunk.

${ }^{530} \mathrm{KmProt}$ VII. $146^{\mathrm{r}}, 149^{\mathrm{r}}-150^{\mathrm{r}}$.

${ }^{531}$ A kolozsvári polgárok végrendeleteit Kovács Kiss Gyöngy vizsgálta a konvent középkori jegyzőkönyvei alapján. Lásd Kovács Kiss: Végrendeletek 49-63.

${ }^{532}$ Uo. 55.

${ }^{53}$ Szende Katalin: Otthon a városban. Társadalom és anyagi kultúra a középkori Sopronban, Pozsonyban és Eperjesen. Bp., 2004. 69.

${ }^{534}$ Kovács Kiss: Végrendeletek 51. Érdekes, hogy a polgárok bevallásait tartalmazó városi könyv vezetését 1601-ben félbehagyták, a XVII. század közepétől pedig már csak tiltakozásokat és ügyvédvallásokat jegyeztek be. Ugyanekkor a kolozsmonostori protocollumok részben liber civitatis jelleget öltenek, minthogy ezekbe másolták a polgárok magánjogi ügyleteiről tett bevallásokat is. Vö. Kiss: Más források 183.

${ }^{535} \mathrm{KmProt}$ VII. 107 ${ }^{\mathrm{r}}-107^{\mathrm{v}}$.

${ }^{536} \mathrm{KmProt}$ VII. $164^{\mathrm{r}}-164^{\mathrm{v}}$.
} 
kezése egyértelműen azt támasztja alá, hogy a kolozsváriak akkor foglaltatták írásba testamentumukat a konventtel, amikor valamilyen módon a városi jog megkerülésével akartak hagyatkozni. Fejérvári a városban levő házának örökösévé feleségét tette, kikötve, hogy újbóli házasságáig az asszonyt a „város törvénye szerint” ne rekeszthessék ki javaiból, amikor viszont férjhez megy, a város törvényét kövessék, addig pedig testamentumát ",senki fel ne boncha se biro se tanach". ${ }^{537}$

A végrendeletek esetében a középkori gyakorlathoz viszonyítva két jelentős különbséget észleltünk, nevezetesen megváltozott a szövegek nyelve, minthogy többségüket anyanyelven foglalták írásba, illetőleg megnövekedett a polgári rendű akaratnyilvánítók száma.

\section{Inventáriumok}

A kolozsmonostori requisitorok a kora újkorban az ügyfelek kérésére, illetve hatósági parancsra egyaránt készítettek ingósági leltárakat. Ezek összeállítására legtöbbször akkor került sor, amikor a kolozsvári polgár visszaadta eredeti birtokosának (általában tágabb környékbeli nemes) vagy az örökösöknek a nála letétbe helyezett értéktárgyakat, tehát többnyire azokat az ingóságokat sorolják fel magyar nyelven, melyeket érdemesnek tartottak a városfalak mögött őrizni. 1587-ben a levélkeresők Kabos Mihálynak néhai Ferenci Antal kolozsvári házánál letett értékeit vették leltárba. A Kabos Mihály által kézhez vett nagy ládában az alábbiakat találták: „,oklevelek és privilegiomok két táskába, az eggyk táska zöld bagaziából, az másik fejér vászonból vagyon, Apahydaról, Twrról, Papfalwaról és Szwchakról való levelek. Az ezüstmarhák kedig ezek: két ezüstös aranyozott hegyestőr, eggyk kazdagb az másiknál. Egy ezüstös szablya, apró kötő vasakkal, régi módra. Egy ezüstös szekerczie, két pogán pénz a közepibe. Egy bokor régi módra való huszár kapcs, ezüst aranyazott, hét pár boglár, rajta az közepin vagyon, két aranyas nyakba vető, eggyk nagyobb másiknál, két fék láncz, ezüst vesszőből kötött, eggyk nagyobb másiknál, egy ezüst kötőfék, az lónak orrára való ezüstel eggyütt, kibe türkesek vadnak, négy ezüst aranyas boglár, fék agyra való, kövek vadnak benne, zöld, veress, kék, tizennégy boglárocskák vadnak, ezüst csattocskák, egy ezüst gombal egyetembe. Vagyon egy magass öreg ezüst aranyazott sima kupa, virágos fedelü, belől az fedelen egy vért vagyon, 1543 esztendőbe csináltatott [...]. Más ezüst aranyozott kupa, kinek a fedelén egy emberke [...]. Egy aranyas kupa fedél virágos, kinek tetején egy kígyós emberke [...]. Egy fél ezüst sarakantyú szí[...]. Vagyon ezek felett két szakadozott hittván sahos

\footnotetext{
${ }^{537}$ KmProt XV. $5^{\mathrm{r}}$ után, számozatlan lapokon.
} 
abrosz, kikbe az ezüst marhák voltak takarva." ${ }^{538}$ A polgárházakban őrzött ládák tartalmáról készült jegyzékek nem veszik számba az élő vagy néhai tulajdonos teljes vagyonát, de a legértékesebb, legféltettebb részét biztosan tartalmazzák. A protocollumokba bevezetett leltárak alapján úgy tünik, hogy a város Basta általi megsarcoltatása után (1601) ritkábban bízták kolozsvári polgárokra a nemesi vagyonok őrzését. ${ }^{539}$

Néhányszor még az is előfordult, hogy teljes vagyoni leltár összeállításával bízzák meg a requisitorokat. Az ilyen jellegü jegyzékek közül forrásértéke miatt kiemelkedő jelentőségű az árván maradt Susalics Zsigmond gyerővásárhelyi vagyonának összeírása. A leltár fölvételére 1587-ben került sor. A kolozsmonostori levélkeresők mellett több tanú, illetve a városból a tárgyak értékének felbecsülésére kirendelt céhtag (ötvös és szabó) vett részt az inventárium összeállításában, amely nem csak az arany- és ezüsttárgyakat, hanem a fegyvereket, ruhaneműeket, házi eszközöket, okleveleket, könyveket, szántókat, jobbágyok neveit is felsorolja. ${ }^{540}$

\section{Szerződések}

Míg a szekularizáció előtt általában birtokperek lezárása érdekében kötöttek egyezségeket a felek, a fejedelemség korában gyakoriak azok a megállapodások, melyeket üzleti szerződéseknek is tekinthetünk. Ezek esetében a két (vagy több) fél többnyire személyesen jelent meg a konvent előtt, de 1627-ből arra is találtunk példát, hogy a levélkeresőket a szerződéskötés helyszínére hívták. Ekkor Bornemisza Ferenc és László Közép utcai házához mentek, ahol írásba foglalták a Lysbona János és Henrik, illetve Bálintffi Kristóf generalis perceptor közötti egyezséget, amely szerint az előbbiek bányászati vállalkozásukban társukká fogadták Bálintffit (,intra sese deliberassent [...] ac certo statuissent antefatum Christophorum Balintfy in cultura auri et argenti fodinarum suarum in territoriis civitatis Rivuliensis Dominarum ac oppidi Mediomontani existentis, aliarumque rerum metallicarum exercitio in contubernium seu campaniam consortiumque suum recipere et annumerare velle"). ${ }^{541}$ A szerződésben hét pontban részletesen rögzítették a kitermelés rendjét, a munkaeszkö-

\footnotetext{
${ }^{538}$ KmProt IX. 98 $-99^{\text {r. }}$.

${ }^{539}$ Több per is indult amiatt, hogy Basta garázdálkodó zsoldosai elkobozták a polgárok házaiban őrzött vagyonokat, a kárért pedig a tulajdonos a polgárt tette felelőssé. Igy járt el Bethlen Gábor is, aki ingóságait Ballos Istvánnál helyezte el, ahonnan „tempore ingressus quondam Georgii Bastae, exercituum caesareanorum generalis facta super huiusmodi depositis dominorum nobilium inquisitione, quidam Germani et nonnulis alii diversae nationis protunc inimici" elvitték, de a fejedelem mégis kára megtérítését kérte. Lásd KmProt XX. $172^{\mathrm{v}}-173^{\mathrm{r}}$.

${ }^{540}$ KmProt IX. 135 $-143^{\mathrm{v}}$.

${ }^{541}$ KmProt XXIII. 29r-30 ${ }^{\mathrm{r}}$.
} 
zök karbantartását, a vállalkozás vezetésének módját (közös praefectus állítása, fizetések megállapítása), illetőleg arra is kitértek, hogy a kilépő fél csakis a vállalkozásnak adhatja el részesedését. Szintén közös bányászati vállalkozás létrehozásáról szól egy 1620-as években kelt egyezség, amely szerint Filstich Lőrinc aranybeváltó - minthogy az aranybányák müvelésére pénzre van szüksége - társának nyilvánítja kolozsvári Váradi Miklóst (az emlékíró Bethlen Miklós nagyapját), azzal a feltétellel, hogy az építések költségeit közösen állják és a haszon mellett a ráfizetést is egyenlő módon vállalják. ${ }^{542}$

Familiárisként teljesítendő szolgálatokról már a középkorban is kötöttek írásos megállapodásokat. A konvent által kiállított 1607. évi egyezség talán csak azért számít különlegesebbnek, mert részletesen taglalja a familiáris juttatásait. Bánffy János arra vállalt kötelezettséget, hogy a Kis Péter nevú nemesnek évente 20 Ft-ot fizet (stipendium annuatim), karazsiaposztóba öltözteti, őt és lovát is élelmezi, és az első két évben átenged számára két hold szántóföldet. Ezen felül a Fehér vármegyei Szentkirályon egy puszta jobbágytelket és egy szőlőt adományoz, vállalva, hogy a telket megnemesítteti. ${ }^{543} \mathrm{~A}$ város határában levő szőlők müvelésének felügyeletével megbízott vincellérekre a középkori jegyzőkönyvekben nem találtunk adatokat, a szekularizáció után vezetett protocollumokban viszont felbukkant néhány egyezség, melyben kötelezettségeiket és fizetésüket taglalják. ${ }^{544}$

Végül egy egyezséget érdekes tárgya miatt tartunk említésre méltónak. 1604-ben tordai Kolozsvári János deák és nagyesküllői Ördög Ferenc egyezett ki egy bizonyos tartozás ügyében. Ördög jószágai visszaváltásáért előzőleg pénzt kölcsönzött János deáktól és adósságából 100 Ft még törlesztetlen maradt. Ezért az összegért lekötötte a Doboka vármegyei Nagyesküllő birtok harangját, melyet ősei öntettek az általuk emelt templom részére. Kolozsvári János a harangot Zsomborra vitte, majd onnan az Szilágycsehre, Gyulaffi Lászlóhoz került. ${ }^{545}$ Ördög az egyezség szerint János deák választására bízza, hogy megtartja avagy eladja a harangot, a 100 Ft feletti összeget pedig az ő kezéhez kell szolgáltatnia. Arra, hogy tartozás

\footnotetext{
${ }^{542} \mathrm{Az}$ oklevél megfogalmazása: „eundem Nicolaum Varadi ratione culturae et elaborationis antenominatarum auri et argenti fodinarum OffenBanyayensis in fidelem et aequalem socium, fratremque et collegam eligendo, adoptando [...] duxisset" (KmProt XXIV. 12 $\left.{ }^{\mathrm{r}}-13^{\mathrm{v}}\right)$.

${ }^{543} \mathrm{KmProt}$ XVI. $21^{\mathrm{r}}-21^{\mathrm{v}}$.

${ }^{544}$ 1629-ben Kovács Gáspár polgár egri Nagy Andrást fogadja fel vincellérnek, hogy Stenczel Ferenc másfél hold szőlőjét múvelje. 1629-re 28 Ft-ot, a következő évre pedig 35-öt kapott (KmProt XXIII. 90v).

${ }^{545} \mathrm{KmProt} \mathrm{XV} .70^{\mathrm{v}}-71^{\mathrm{r}}$. A szilágycsehi református templomnak két középkori harangját ismerjük, valószínűleg ezek közül lehetett valamelyik az egyezségben említett. Lásd Emődi Tamás: A szilágycsehi református templom. Erdélyi műemlékek 21 (1996). 10.
} 
zálogaként egy harang szolgáljon, sem a korábbiakban, sem a későbbiekben nem találtunk példát.

\section{Inskribálások}

A fiskális jószágok hasznosításában követett gyakorlatban lényeges különbség mutatható ki a fejedelemség és a királyság között. Míg ez utóbbiban a király örök adományként adta a birtokokat híveinek, addig Erdélyben a fejedelem fiskális jószágot nem adományozhatott el, hű szolgálatokért csak ideiglenes zálogként bocsáthatta ki ezeket kezéből. ${ }^{546} \mathrm{Ez} \mathrm{az}$ ún. inskribálás, amely a meghatározás szerint „,szolgálatok jutalmazására valamilyen ingatlannak ingyen vagy értéken aluli összeg fejében bizonyos időre való átengedése a megjutalmazandó számára". ${ }^{547}$ Ez a meghatározás azonban nem fedi teljes egészében az inskripciók körét, inkább csak az uralkodó által történt elidegenítésekre vonatkozhat. Vélhetően a fejedelem mintájára magánszemélyek is inskribáltak jószágokat, tehát hűséges szolgálataikért familiárisaiknak zálogcím alatt adományoztak. ${ }^{548} \mathrm{Az}$ így birtokhoz jutó donatariusnak számított, az oklevelet pedig inscriptiónak vagy donatiónak nevezték és úgy is fogalmazták. ${ }^{549} \mathrm{~A}$ főurak általában servitoraikat jutalmazták ilyen módon, 1607-ben például Kovacsóczi István a Fehér vármegyei Újfaluban levő nemesi telkét inskribálta nemes szolgálójánál, ${ }^{550}$ 1609-ben pedig Bethlen Gábor tanácsúrként több Kolozs megyei birtokrészt kötött le kolozsvári Bornemisza Tamásnál. ${ }^{51}$ Forrásaink szerint függőpecsétes oklevelet inskribálásról először 1583-ban állítottak ki, ekkor Peres Márton sebészként teljesített szolgálataiért („,chyrurgica eiusdem curatione qua ipsum Martinum [...] plurimis et lethalibus sauciatum vulneribus diligentissime curasset") 200 magyar Ft-on örökösen Bor-

\footnotetext{
${ }^{546}$ Jakó: Gyalu XXIX-XXXI.

${ }^{547}$ Úriszék 1014.

${ }^{548}$ Dósa: Jogtudomány 332-333.

${ }^{549} \mathrm{Az}$, hogy valójában adományozásról van szó, a jegyzőkönyvi bejegyzések címeiből is kiderül, egy 1607-ben kelt inscriptio címe: „Sessio quaedam nobilitariam in Wyfalw in Albensis c. Emerico Kakuchi per Stephanum Kovachoczi donata." Emellett a szöveg is inkább adományozásra vall: „ipse matura intra se deliberatione prehabita, attentis et consideratis fidelitatem et fidelibus servitiis nobilis Emerici Kakuchi servitoris sui, quae ipse hactenus quovis tempore, in cunctis rebus suae fidei commissis probe et strenue obivisset et exhibuisset ac in futurumque exhibiturus ei impensurus esset, quandam totalem et integram sessionem suam nobilitarem [...] annotato Emerico Kakwchi, haeredibusque et posteritatibus suis utriusque sexus universis, in summa florenorum ducentorum Hungaricalium duxisset inscribendam et obligandam, prout inscripsit et obligavit", kikötve, hogy örökösei csak a nevezett összeggel válthatják ki a jószágot (KmProt XVI. $\left.9^{v}\right)$.

${ }^{550} \mathrm{KmProt}$ XVI. 9v-10

${ }^{551} \mathrm{KmProt}$ XVII. $30^{\mathrm{r}}$.
} 
bély Jánosnak inskribálta Kraszna mezővárosi nemesi telkét. 552 1617-ben újból privilegiális oklevelet adtak inskribálásról, amely értelmében Apafi György és Ferenc, Kákoni István tanácsúr közbenjárására, illetőleg hüséges szolgálataiért Balázstelkén található jobbágytelküket 300 Ft-on Csontos Gergelynél kötötték le (,dedissent, donassent, contulissent, atque in summam integram trecentorum florenorum Hungaricalium inscripsissent ac obligassent"), a telken levő házat pedig megnemesítették. ${ }^{553}$

Más jellegúek azok az inskribálások, melyeket a házastársak egymás között kötöttek meg. Ezeket a jogtudós Dósa Elek „,a férj és feleség közötti elzálogosítás" cím alatt tárgyalta, és felsorolta azokat az eseteket, melyek megengedték, hogy az egyik fél ősi jószágait a másiknál kösse le.554 1609-ben Tholdalagi János magtalan halála esetére 1000 Ft-on feleségénél, Gyerőfi Borbálánál kötötte le Kolozs és Doboka vármegyei jószágait. ${ }^{55}$ Az oklevél narratiójából az inskribálás indokára is fény derül. 1603-ban, amikor Radul havaselvi vajda győzelmet aratott Székely Mózes felett, Tholdalagi fogságba került, ahonnan felesége - bizonyára nem kis összeg árán - kiszabadította. Hasonlóan járt el Kamuthi Balázs házastársa, Zeller Angléta is, aki saját költségén mentette meg férjét Basta kezeiből. Kamuthi hálája jeléül $6000 \mathrm{Ft}$-on neki inskribálta jószágait. ${ }^{556} \mathrm{E}$ bevallásokat tehát nem pénzszűke miatt (,pro arduis necesitatibus”) kötötték, mint a zálogosításokat általában, hanem az inskribáló célja az volt, hogy házastársa irányában fennálló tartozását törlessze, vagy annak későbbi, esetleg örökösei általi törlesztését biztosítsa. Az így lekötött jószágokat az atyafiság csakis az általában igen magasra szabott inskripciós összeg törlesztésével válthatta vissza.

\section{Zálogosítások, kölcsönügyletek}

A nemesi birtokforgalom egyik leggyakoribb középkori formája a zálogosítás volt. A szekularizáció előtt kötött zálogosításokban a kamat kérdése soha nem merül fel, az oklevél formulái nem említik. ${ }^{557}$ A kora újkori kolozsmonostori protocollumokba vezetett zálog- és kölcsönügyle-

\footnotetext{
${ }^{552} \mathrm{KmProt}$ VII. $154^{\mathrm{v}}-155^{\mathrm{r}}$. A borbélyt és örököseit meg is nemesítette, azzal a feltétellel, hogy élete végéig szolgálja.

${ }^{553} \mathrm{KmProt}$ XVI. $114^{\mathrm{r}}-114^{\mathrm{v}}$.

${ }^{554}$ Dósa: Jogtudomány 486-487. Házastársak közötti inskripciók Kolozsmonostoron már a szekularizáció előtt történtek, lásd (a teljesség igénye nélkül) KmJkv II. 4947., 4972., 5012. sz. A budai káptalan középkori jegyzőkönyvébe is vezettek hasonló jellegű bejegyzéseket, vö. Kubinyi-Fügedi: A budai káptalan 41.

${ }^{555} \mathrm{KmProt}$ XVII. $148^{\mathrm{r}}$.

${ }^{556} \mathrm{KmProt}$ XVI. $136^{\mathrm{v}}$.

${ }^{557} \mathrm{Vö.}$ Kubinyi-Fügedi: A budai káptalan 41. A kolozsmonostori konvent középkori jegyzőkönyveiben sem említenek kamatot.
} 
tek esetében azonban a XVI. század második felétől - ritkán ugyan - megjelenik, a következő században pedig említése gyakrabbá válik. Az első adatok nem is a pénzügyekben jártas kolozsvári polgárokhoz köthetők, hanem nagy tőkével rendelkező főnemesekhez. A legkorábbi esetről egy 1582. évi konventi átiratból értesülünk. 1554-ben Possay Bertalan magyar nyelvủ kötelezvényt adott arról, hogy Kendi Ferenc erdélyi vajdától 6000 Ft-ot kölcsönzött, melyet - 1000 Ft-os kamatjával együtt - egy év múlva, a következő virágvasárnapra fizet vissza. ${ }^{558} \mathrm{~A}$ következő oklevélben már birtokok elzálogosításáról, illetőleg az azok hasznából származó kamatjövedelemről is szót ejtenek. 1581 áprilisában Báthory István udvari familiárisa, Kendi Péter azért kötötte le Bihar megyei jószágait, mert a moszkvaiak ellen hadba indult. Sombori László tanácsúr jelentős összeget, $2000 \mathrm{Ft}$-ot adott kezéhez, ezen felül kikötötték, hogy a birtokok közönséges és szokásos jövedelmeiből évente 200 Ft kamatot vehet fel („,pro lucro seu interese pecuniae suae accipere debeat"), ha viszont a jövedelmek meghaladják a $200 \mathrm{Ft}-\mathrm{ot}$, az azon felüli rész a zálogösszeghez adódjon („,in supplementum duorum millium florenorum deputari debeat"). ${ }^{559}$

A gondolkodásmód egyértelmű megváltozását jelzik a kölcsönügyletekre vonatkozó azon bejegyzések, melyek a kolozsvári református egyházközség „,befektetéseiről” tájékoztatnak. 1644-ben a konvent bizonyította, hogy Váradi Miklós kolozsvári főbíró azon összeget, melyet nemrég néhai Szemerei György a reformátusokra hagyott, átadta kamatoztatásra a városi szász református egyház első lelkésze (concionator primarius) vejének, Nürnbergi György deáknak. ${ }^{560}$ Egy másik nyugta azt is adatolja, hogy mekkora jövedelme származhatott az egyháznak az ilyen jellegü kamatoztatásokból. 1648-ban Székesfehérvári Benedek deák visszaszolgáltatta azon 1000 Ft-ot, melyet néhai Bethlen István az egyháznak rendelt. Az öszszeg tíz éven keresztül nála volt és évente 10 Ft-ot kamatozott. ${ }^{561}$

\section{Oklevélátírások}

Transsumptumokat a konvent a középkor folyamán, illetve a szekularizációt követően, az 1575. évi rendezésig is állított ki. Már korábban megállapítottuk, hogy a requisitorok hivatalba állításáig az átiratok kiadása a város felügyelete alatt folyt, és hatósági parancsra (királynéi, választott királyi, vajdai) a konvent levéltárából való másolatok kiállítására szorítkozott. Az újjászervezés után az eredeti irataikat féltő ügyfelek újból felkereshették a konventet, hogy birtokukban levő jogbiztosító oklevelükről hite-

\footnotetext{
${ }^{558} \mathrm{KmProt}$ VII. $160^{\mathrm{r}}-160^{\mathrm{v}}$.

${ }^{559}$ Uo. $117^{\mathrm{v}}-118^{\mathrm{r}}$.

${ }^{560} \mathrm{KmProt}$ XXXI. 59v-60r.

${ }^{561} \mathrm{KmProt}$ XXXII. 25ㄴ $-26^{\mathrm{r}}$.
} 
les másolatot állíttassanak ki. Ezekben az esetekben az oklevél tulajdonosa megjelent a requisitorok előtt, és - bevallást téve - kérte ügyének írásbeli rögzítését, ami ilyenkor a bemutatott oklevélnek szóról szóra történő lemásolását és konventi pecsét alatt való kiadását jelentette. ${ }^{562}$

Adataink arra utalnak, hogy az eredeti oklevélről nem minden esetben adták ki a másolatot, hanem úgy biztosították szövegének megőrzését, hogy azt a közhitelességgel bíró protocollumokba másolták. ${ }^{563} \mathrm{Az}$ átiratok vagy másolatok indoklásából is kiderül, hogy az ügyfél esetenként megelégedett oklevele szövegének jegyzőkönyvbe való rögzítésével, és nem igényelte a konvent kiadványát..$^{564}$ Ekkor biztosan nem hajtották be rajta a transsumptum kiállításának díját, hanem egy annál vélhetően kisebb öszszeget kellett fizetnie a beírásért. A protocollumokba másolt iratok tárgyilag igen változatosak, minthogy a felek mindent beírattak, amit megőrzésre érdemesnek véltek. Legnagyobb számban nemesítéseket, adományleveleket másoltattak be (és ezekről állíttatták ki a legtöbb átiratot), de előfordulnak kiváltságlevelek birtok tizedmentességéról ${ }^{565}$ nyugták és elszámolások (alispáni, vármegyei adószedői stb.), ${ }^{566}$ vagy Székely Mózes fejedelem utasítása az aranyváltásról, melyet azért iktattak, mivel „eosdem certis in partibus ipsius regni Transsilvaniae circumcirca transmitti moreque solito publicari facere necessum haberet formidaretque, ne in huiusmodi circumportatione in tanta rerum et omnium statuum confusione quoquomo-

${ }^{562}$ A középkori gyakorlatra lásd Dreska Gábor: A pannonhalmi konvent hiteleshelyének 14. századi oklevélátírásai. In: Mons Sacer I. Pannonhalma, 1996. 463-470.

${ }^{563}$ Kiss András megállapítása szerint a hiteleshelyek esetében is „hiteles oklevélkibocsátó joguk alapján a közhitelüség könyv alakú belső ügyviteli irataikra is vonatkozott, jóllehet ezek szövegeit nem pecsételték meg". Ezekbe a protocollumokba vezették be a bemutatott oklevelek másolatait. Lásd Kiss: Más források 174-175.

${ }^{564}$ 1619-ben adománylevelet másolnak protocollumba, az alábbi indoklással: „petens nos debita cum instantia ut nos easdem in librum seu prothocolon huius Conventus Colosmonostrensis inseri et inscribi ac cum temporis necessitas ita expostularet sub sigillo nostro authentico extradari facere vellemus" (KmProt XX. 144r). Szó szerint ugyanaz az indoklás egy 1622-es bemásolásnál, lásd KmProt XXI. 14r. 1631-ben egy nyugtát másolnak jegyzőkönyvbe a következő indok alapján: „petens nos debita cum instantia, ut nos easdem pro tutione, remansione et conservatione in protocolon seu librum istius Conventus Colosmonostrensis transcribendo et transumendo in Archivum tandem nostrum, ea potissimum de causa reconderemus, quod in originalis [?] praescripta pendicando [?] contingerent, paria ex hoc conventu jurium eiusdem Francisci litterati Medgyesi ad cautelam recipi possint" (KmProt XXVIII. 33r).

${ }^{565} \mathrm{KmProt} X V I .6^{\mathrm{r}} 7^{\mathrm{v}}$ : János Zsigmond ítéletlevelét másolják be a Fehér vármegyei Tompaháza birtok lakosai kérésére („,earum paria protocolo nostro conventuali pro futura dictorum incolarum Tompahaza cautela et [...] conservatione earundem litterarum [...] inserere vellemus").

${ }^{566}$ 1616-ban Máramaros vármegye alispánja, Pogány Péter kérésére másolnak be kifizetéseiről és elszámolásairól nyugtákat (KmProt XX. $\left.7^{\mathrm{r}}-8^{\mathrm{r}}\right), 1618$-ban a Kolozs megye adójáról kiadott elszámolást iktatják be $\left(\mathrm{KmProt} X X .77^{\mathrm{r}}-77^{\mathrm{v}}\right)$. 
do periclitari contingat" ${ }^{567} \mathrm{Az}$ oklevelek jegyzőkönyvbe való másolásakor alkalmanként részletekbe menő leírást adnak az eredeti dokumentumról, a díszítésekről, a betük alakjáról, illetve az eredeti hátoldalán levő jegyzeteket is lemásolták, így időnként arra is fény derül, hogy a nemesítést hol és mikor publicálták. 1607-ben a Berkeszy Péternek Bocskai által adományozott címereslevelét protocollumba másoló levélkereső megragadó leírást adott a szemet gyönyörködtető címerképről, ${ }^{568}$ az 1640-es években pedig Pálfi István requisitor taglalta III. Ferdinánd címeradományának szépségét. ${ }^{569}$ Pálfi kora egyik legtehetségesebb kalligráfusa lévén, biztosak lehetünk abban, hogy hozzáértő véleményt fogalmazott meg.

A protocollumok egyre inkább az országos jelentőségű iratok őrzőivé is váltak azáltal, hogy a fejedelmek is bemásoltatták a fontos szerződések szövegeit valamelyik hiteleshely jegyzőkönyvébe. Így került a kolozsmonostori protocollumokba a nagyszombati egyezség országgyưlés által megerősített változata, ${ }^{570}$ vagy II. Rudolf oklevele Báthory István részére Szatmár és Németi mezővárosok, illetve Nagybánya mezőváros cseréjéről. ${ }^{571} \mathrm{~A}$ másolatok mellett a requisitorok természetesen eredetiben is orriztek jogbiztosító iratokat, illetve országos fontosságú dokumentumokat, de ezekről a konvent levéltárát tárgyaló fejezetben lesz szó.

\footnotetext{
${ }^{567} \mathrm{KmProt} X \mathrm{X} .132 \mathrm{v}$.

${ }^{568}$ „Insignia quae a laeva parte in primordio earundem litterarum nobilitationalium docta pictoris manu suis naturalibus formis et coloribus mirabili qualitate, artificiosoque ordine depicta, diversis laciniis seu lemniscis circa fluitantibus adornata et effigiata et postea eiusdem serenitatis nomen et titulus aureis characteribus descriptus pulcherime variorum [?] formarum paradigmatibus intermixtis et venustate fere ineffabili coloratis insignitus inspicientium seu contemplantium oculos in delectionem incitare, ac animos in admirationem trahere videbantur contulisse dinoscebatur, petens nos debita cum instantia ut nos easdem in protocolon seu librum conventus Colosmonostoriensis inscribi et inseri faceremus" (KmProt XVI. $\left.26^{r}-26^{v}\right)$.

${ }^{569}$ „Litterae autem erant in integro pergameno patenter confectae et titulus imperatoriae maiestatis in prima et secunda linea litteris maioribus capitalibus, aliis vero quattuor lineis maioribus litteris sed per omnia auro obryzo conscriptae, insigniisque in capite litterarum pulcherime et artificiose appositis et depictis, jucundissime exornatae, in inferiori margine erat sigillum duplex appositum in zona sericea, albi flavi, cerulei et rubri coloris, praeterea scriptio tota pulchra, pura et exacta, ita ut intuentium oculi admirabili quadam delectatione pascerentur et ab earum visu vix avellerentur. Tenor autem litterarum talis erat [...]" (KmProt XXVIII. 135r).

${ }^{570}$ A bemásolásra 1617. november 11-én került sor, az oklevelet Erasmus Adam titkár és Patkó János kancelláriai íródeák mutatták be a konventnél. A requisitorok az alábbiakkal indokolták a bevezetést: „Quas nos de verbo ad verbum, sine diminutione et augmento, variationeque aliquali transumi et transcribi, presentemque in librum huius conventus in perpetuam rei memoriam ac prefati domini principis et totius Regni Transilvanicae partiumque Hungariae eidem annexarum futura pro cautela inseri et inscribi fecimus" (KmProt XX. $\left.53^{\mathrm{v}}-56^{\mathrm{v}}\right)$.

${ }^{571} \mathrm{KmProt} X V .255^{\mathrm{r}}-255^{\mathrm{v}}$.
} 
Más esetekben az oklevél szövegének bemásolásával egyidejűleg konventi pecséttel megerősített átirat kiállítására is sor került. Erre szintén az indoklásokból derült fény. 1610-ben például Kewy György azzal a kéréssel jött a requisitorok elé, hogy két adománylevelét másolják be a protocollumba, és állítsanak ki azokról transsumptumot is: „petens nos debita cum instantia ut nos earundem copia seu paria transumto literarum nostrarum inserentes juris eiusdem Georgii Kewy futura pro cautela sub sigillo huius conventus usitato extradare et earum etiam exempla protocolo nostro conventuali inscribere vellemus". ${ }^{572}$ A protocollumba való bemásolás mellett átirat kiállítását kérte 1634-ben Horvát Mátyásnak Giróti Margittól született leánya, Klára, aki azért igényelt másolatot a Girótiak családfájáról, mert férje a pestisjárványban meghalt, neki pedig egyetlen leánya maradt. ${ }^{573}$

Érdekes és a kor viszonyaira jellemző esetként említhetjük meg a konvent 1666. május 21-én kelt oklevelét. ${ }^{574} \mathrm{~A}$ Szalárdi által kiállított átirat azt bizonyítja, hogy a Toroczkaiakat képviselő Szaniszló Albert ügyvéd a konvent előtt bemutatott egy protocollumot, amely a jelek szerint az elmúlt zavaros időkben a gyulafehérvári káptalan levéltárából került Havaselvi László Kolozs vármegyei főszolgabíró kezéhez. Az átírást kérő ügyfél tehát egy egész jegyzőkönyvvel jelent meg, és ennek a Toroczkaiakra vonatkozó néhány lapját íratta át. A kalandos sorsú protocollum később valahogyan visszakerült a káptalani levéltárba, ahol jelenleg is ôrzik. ${ }^{575}$

Minden átírást természetesen alapos körültekintéssel hajtottak végre. A bemutatott oklevél hitelességének bizonyítására a formai és a tartalmi jegyeket tüzetesen megvizsgálták, és ha bármilyen gyanú merült fel, megtagadták az átirat kiállítását. 1654-ben például Küküllő vármegye gyanúsnak talált misszilis leveléről csak külön fejedelmi mandatummal voltak hajlandók másolatot adni ügyfelüknek, aki „exhibuit literas quasdam missiles comitatus de Kwkeolleo illustrissimo principi Georgio Rakoczy seniori sonantes, anno Domini 1648 scriptas, tritas et maculatas, cancellatasque ad transummendum: quae quia suspectae videbuntur ergo sunt remissae ad ill. D. principem eo fine quod si sua Cels. Literas preceptorias superinde dare [...] fuerit et reportabuntur, ita tamen transsumentur" ${ }^{576}$

\footnotetext{
${ }^{572} \mathrm{KmProt}$ XVI. $182^{\mathrm{r}}-182^{\mathrm{v}}$.

573 "Copiam seu paria prescripte genealogiae tum in archivum nostrum recondere, tum vero transumpto litterarum nostrarum inserere [...] sibi extradare vellemus" (KmProt XXVIII. $\left.81^{v}\right)$.

${ }^{574}$ DF 257862. Vö. CDTrans I. 492. sz.

${ }^{575}$ Jelzete: MOL F2. XIII. Vö. ErdKápJkv VIII/1. 10.

${ }^{576} \mathrm{KmProt}$ XXXV. $1^{\mathrm{r}}$.
} 


\section{A kolozsmonostori konvent vonzáskörzete és forgalma a fejedelemség korában}

A hiteleshelyek múködését bemutató tanulmányokban külön kezelik azt a területet, ahonnan a lakosok felkeresték az intézményt, illetőleg azt, ahol a kiküldöttek hatósági parancsra külső hiteleshelyi tevékenységet végeztek. ${ }^{577} \mathrm{~A}$ kolozsmonostori konvent vonzáskörzetének a bevallások alapján történő pontos megrajzolása - véleményünk szerint - több akadályba ütközik. Először is a bevallást tevők lakóhelye sok esetben nem állapítható meg. Noha a nemesi névadás rendszerint helynevek alapján történt, csak ritkán lehetünk bizonyosak abban, hogy az a bevalló lakóhelyét is jelöli. Az ügyfélnek lehetett több udvarháza, melyek közül bármelyikben lakhatott, de tartózkodhatott huzamosabb ideig vagy állandóan kolozsvári saját vagy bérelt házában is. Újabb nehézséget jelent, hogy egy-egy hiteleshely vonzáskörzetének és forgalmának befolyásolásában egyéb tényezők is közrejátszottak. Kolozsvár a kora újkorban az országgyülések gyakori helyszíne. Ekkor az ország nemességének színe-java a városban tartózkodott, és jogi ügyleteit az ugyanott működő hiteleshellyel foglaltatta írásba. ${ }^{578}$ Ilyenkor természetes, hogy a forgalom növekedése mellett a konvent területi hatósugara is növekszik, magában foglalva olyan területeket, melyekröl bevallókat a jelentős távolság miatt nem várnánk. Szintén forgalomnövekedéssel számolhatunk a vármegyei közgyűlések alkalmával, melyeket a XV-XVI. század fordulóján olykor, a XVI. század végétől pedig rendszeresen a városban tartottak. ${ }^{579}$

Gyakorlati okokból csak ritkán kereste fel a konventet idegen országban, más uralkodó fennhatósága alatt élő ügyfél. Ez általában csak a kereskedők, faktorok vagy olyanok esetében fordult elö, akiket valamilyen fontos helyi birtokügylet a konvent előtti bevallástételre késztetett. Az bizonyos, hogy a fejedelem fennhatósága alá tartozók számára nem volt ildomos erdélyi ügyekben a Habsburg-országrész valamelyik hiteleshelyét felkeresni, és e tiltás valószínűleg fordítottan is érvényben lehetett. 1632-ben például néhai Bálintffi Kristóf özvegye, Bornemisza Katalin azzal követte el a hűtlenség bűntettét, hogy a fejedelem elleni tiltakozását megbízottja

${ }^{577}$ Dreska: A pannonhalmi konvent 20.

${ }^{578}$ A középkorban már a XIV. század második felében élt az a gyakorlat, hogy a konvent két-három tagja, olykor maga az apát is, megjelent a vajdai közgyưlésen a bevallások felvétele végett. Lásd KmJkv I. 36-37.

${ }^{579}$ W. Kovács András: Megyeszékhelyek a középkori Erdélyben. In: Emlékkönyv Egyed Ákos születésének nyolcvanadik évfordulójára. Kolozsvár, 2010. 183-185. 
útján az egri káptalannal foglaltatta írásba, és e vétkéért jószágvesztésre ítélték. ${ }^{580}$

Az említett bizonytalanságok mellett sem tartjuk azonban teljesíthetetlen feladatnak a konvent kora újkori vonzáskörzetének, illetőleg törzsterületének megközelítő pontossággal való felvázolását és a középkori, szekularizáció előtti illetékességi területtel való összevetését. A középkori illetékességi terület megállapításánál a Sipos Gábor által ${ }^{581}$ a bevallásokban előforduló helységnevek alapján végzett számításokat összevetettük a konvent középkori jegyzőkönyveinek adataival. A fejedelemség kori vonzáskörzet megállapításához szintén a protocollum-bejegyzéseket vettük alapul (négy fejedelemség kori jegyzőkönyv anyagát dolgoztuk fel). Ismeretes, hogy nem került minden konventi kiadvány bejegyzésre, illetve a protocollumok között előfordulnak kronológiai átfedések, de a jegyzőkönyvek így is vélhetően elegendő bejegyzést tartalmaznak ahhoz, hogy helytálló következtetéseket vonhassunk le belőlük. Minden esetben arra törekedtünk, hogy csupán azokat a bevallásokat vegyük számításba, melyeknél az ügyfél/ügyfelek lakóhelye nagy valószínűséggel megállapítható volt. Számításainkat összesen mintegy 1000 bevallás alapján végeztük.

A Jakó Zsigmond által regesztákban kiadott középkori jegyzőkönyvekből az 1465-1468 (KmJkv I., 1676-1833. sz. kivonatok), illetve az 1538-1540 (KmJkv II., 4635-4762. sz. kivonatok) közötti bevallásokat dolgoztuk fel. Tetszőlegesen két olyan időszakot választottunk ki, melyekből a jegyzőkönyvi bejegyzések folyamatosan fennmaradtak. ${ }^{582} \mathrm{~A}$ tanulmányozott XV. századi bevallások (lásd alább) alapján ekkor egyértelműen a konvent vonzáskörzetéhez tartoztak a történeti Erdélyen kívülre eső vármegyék is, nevezetesen Közép-Szolnok és Kraszna. A legtöbb ügyfél nyilvánvalóan Kolozs megyei volt, majd a dobokaiak következtek, feltűnő viszont Torda vármegye lemaradása. Kolozsvár ekkor még csak néhány bevallással szerepel, a polgárok tehát (még) nem a konvent előtt foglaltatták írásba ügyleteiket. Számításaink eredményei különböznek a Sipos Gábor által felvázolt képtől (ott a konvent törzsterülete, vélhetően csökkenő sorrendben Kolozs, Torda, Doboka, Belső-Szolnok és Fehér vármegye északi része), ${ }^{583}$ de jóval nagyobb számú bevallás feldolgozása esetén valószínüleg még változna mindkét sorrend.

\footnotetext{
${ }^{580}$ Bejegyzés az EME egykori Kézirattárában (Egyetemi Könyvtár Kézirattára) őrzött for-

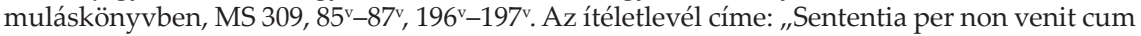
quis clandestine contra majestatem seu dignitatem principalem extra regnum in locis capitularibus falsis aut facinorosis utitur querelis et protestationibus".

${ }^{581}$ Sipos: Kolozsmonostor 43.

${ }^{582}$ Vö. KmJkv I. 151-152.

${ }^{583}$ Sipos: Kolozsmonostor 43. Torda vármegye valószínűleg tévesen került a második helyre, az általunk végzett felmérésekben mindig Doboka után következik, talán a dobokai nemesek jóval nagyobb száma miatt.
} 

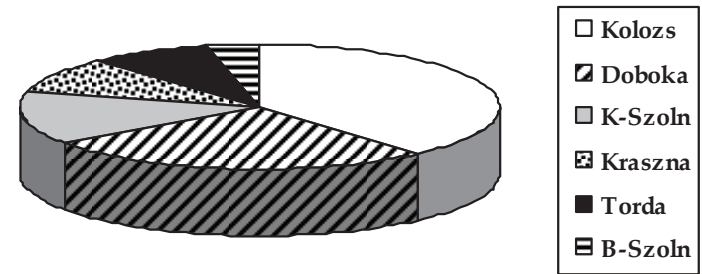

Az 1538-1540 közötti bevallásoknál (lásd alább) rögzül az a sorrend, amely kisebb változásokkal lényegében több mint száz éven át a konvent (vármegyei) törzsterületét alkotta: Kolozs, Doboka, Torda. A Meszesen túli megyékből csak kivételesen tettek bevallást a konvent előtt, és a kolozsváriak is elvétve szerepelnek.

\section{A kolozsmonostori konvent vonzáskörzete 1538-1540 között}
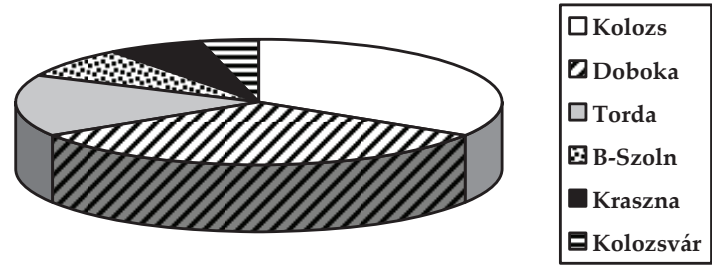

A szekularizáció utáni időszakból először a legelső fennmaradt jegyzőkönyv anyagát dolgoztuk fel (KmProt VII., 1576-1584, l. grafikon). Ekkor észlelhető a fentebb említett kisebb változás, amely lényegében a sorrendet is megváltoztatta: Kolozsvár a második helyen szerepel és ezentúl a bevallást tevők tekintélyes része városi polgár marad. ${ }^{54} \mathrm{Az}$ Erdélyen kívüli megyék lakói is nagy számban keresték fel a hiteleshelyet, Közép-Szolnok mellett a grafikonon már nem szereplő Krasznából is viszonylag sokan jöttek.

${ }^{584}$ Habár Werbőczy szerint városi ingatlanokra vonatkozó bevallást csak a városi hatóság előtt lehetett tenni (Tripartitum 395), a kolozsvári gyakorlat azt mutatja, hogy a polgárok már a szekularizáció előtt a kolozsmonostori konventnél rendelkeztek városi és vármegyei birtokaikról, a hiteleshely újjászervezését követően pedig ez az eljárás még fokozottabban jelentkezett, annyira, hogy egy-egy protocollum „városi könyv” jelleget öltött. 
A kolozsmonostori konvent vonzáskörzete 1577-1584 között
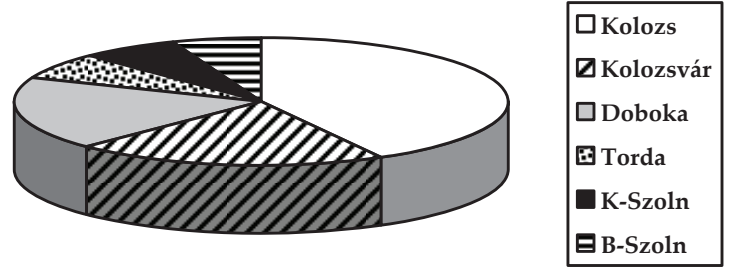

Az 1590-1600 közötti időszak (KmProt X.) érdekes változása Fehér megye előretörése és az Erdélyen kívüli megyék kikerülése a konvent törzsterületéből. A Kolozs, Doboka, Torda sorrend továbbra is megmaradt, Doboka és Torda közé azonban bekerültek a kolozsvári bevallók, akik tekintélyes számban keresték fel a városba költözött hiteleshelyet.

A kolozsmonostori konvent vonzáskörzete 1590-1600 között

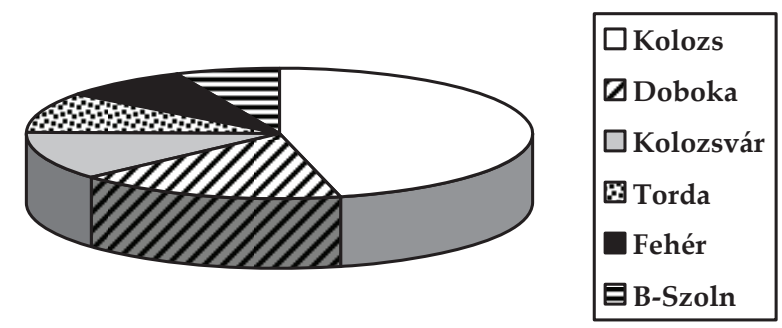

A következő vizsgált periódus (1607-1614, KmProt XIII.) feltűnő változása Kolozsvár első helyezése, de megjegyzendő, hogy az első két helyezett közötti különbség csekély. Fehér megyeiek továbbra is viszonylag nagy számban keresték fel a konventet, Közép-Szolnok és Kraszna azonban szinte teljesen kikerült Kolozsmonostor vonzáskörzetéből.

A kolozsmonostori konvent vonzáskörzete 1607-1614 között

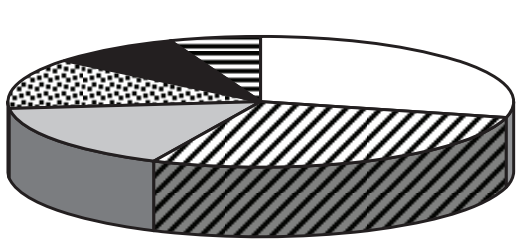

\begin{tabular}{|l|}
\hline$\square$ Kolozsvár \\
$\square$ Kolozs \\
$\square$ Doboka \\
⿴囗orda \\
$\square$ Fehér \\
B B-Szoln \\
\hline
\end{tabular}


Az utolsó grafikon a konvent 1647-1655 közötti (KmProt XXXIII.) vonzáskörzetét ábrázolja. Ebben az időszakban már nyomon követhető a hiteleshelyi tevékenység hanyatlása, ami a létszámhiány és a requisitorok fejedelmi adminisztrációban való „,bevetése” miatt következett be. A bevallások jellege is nagyot változott, nagy részben ügyvédvallásokat és tiltakozásokat vettek fel (egy levélkereső ügyvédvalláson kívül egyébről nem is adhatott oklevelet). A fenti okokból következően a vonzáskörzet is leszűkült lényegében Kolozsvárra és Kolozs vármegyére, a szomszédos vármegyék jóval kisebb arányban vannak képviselve. Feltünő és valószínűleg csalóka a székelyföldi bevallók nagy aránya. Közülük bizonyára csak kevesen jöttek a székekből bevallást tenni, nagyobb részük már Kolozsváron lakhatott, a nemesi előnév valószínűleg csak származásukat jelölte.

\section{A kolozsmonostori konvent vonzáskörzete 1647-1655 között}

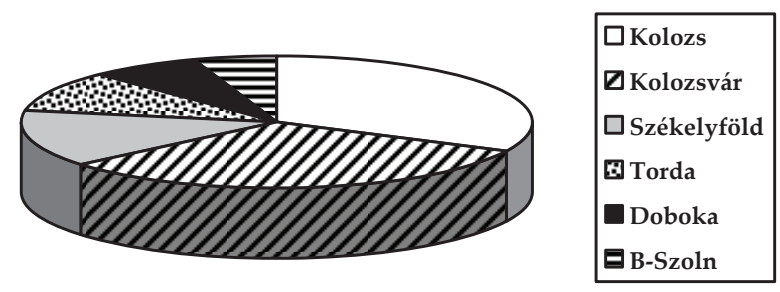

\section{A konvent forgalma}

A hiteleshelyi oklevélkiadás a konvent újjászervezése után (1575 őszén), vélhetően csak 1576 elején/közepén indult meg. Ezt támasztja alá az, hogy az ebből az évből való egyedüli jegyzőkönyvi bejegyzés június 12-én kelt. ${ }^{585}$ Ebből arra következtethetünk, hogy az oklevéladó tevékenység a kezdetekben gyér lehetett, 1577-től viszont már legalább havi rendszerességgel állítanak ki oklevelet. Minthogy a lelesziekhez hasonló oklevéltaxa-jegyzékekkel nem rendelkezünk, a forgalom további alakulását csupán a protocollumok bejegyzései alapján becsülhetjük fel. Le kell azonban szögeznünk, hogy nem került minden kiadvány bevezetésre, ezért számaink viszonylagosak. Ezek alapján azt a következtetést vonhatjuk le, hogy a kora újkori konvent fénykorának tekinthető XVI. század végén napi rendszerességgel állítottak ki okleveleket. Természetesen voltak olyan napok, amikor az oklevéladó tevékenység valamilyen okból szünetelt (vagy a múködésnek nem maradt nyoma), de olyanok is, amikor négyöt oklevelet adtak ki. Biztosan forgalomnövekedéssel járt egy-egy Kolozs-

${ }^{585} \mathrm{KmProt}$ VII. $13^{\mathrm{v}}-14^{\mathrm{r}}$. 
váron tartott országgyülés vagy vármegyei közgyưlés, viszont a forgalom csökkenését eredményezte a háború vagy pusztító járvány. Nagyjából a XVII. század közepétől jelentős mértékben hozzájárulhatott a konvent forgalmának csökkenéséhez az, hogy a fejedelem - vélhetően anyagi megfontolásból - hosszú ideig betöltetlenül hagyta az egyik requisitori állást, és ezzel párhuzamosan gyakran bízott a levélkeresőkre egyéb teendőket (inventáriumok felvétele, lustrák összeállítása, udvarbírák beiktatása stb). ${ }^{586}$ A forgalom tehát csökkent, a Szalárdi által 1664-1666 között vezetett jegyzőkönyvi bejegyzések alapján megállapíthattuk, hogy már csak havonta 4-5 alkalommal tettek bevallást a hiteleshelyen. ${ }^{587} \mathrm{Az}$ a tény, hogy az elöbb említett protocollum után már csak egy - tágabb értelemben fejedelemség korinak tekinthetö, az 1690-es évek bejegyzéseit tartalmazó - jegyzőkönyv maradt fenn, egyértelműen a konventi hiteleshely gyérülő forgalmára, az intézmény oklevéladó szerepének további csökkenésére utal.

\section{2. A konvent külső hiteleshelyi tevékenysége a fejedelemség korában. A jelentések}

A hiteleshelyek a középkorban jelentős szerepet játszottak az országos bíráskodásban és a közigazgatásban is, a közhatóságok kisegítő szerveiként. Különböző birtokügyekben jártak el és részt vettek a peres eljárások szinte minden szakaszában. ${ }^{588} \mathrm{~A}$ hatósági parancsok végrehajtása a legkülönbözőbb ügyekben is lényegében azonos módon folyt le. A parancslevélben megnevezett több nemes közül egy mint hivatalos kiküldött (királyi ember, vajdai ember) kiszállt a helyszínre a parancs végrehajtása végett. Tanúbizonyságként vele ment a hiteleshely megbízottja. Munkájuk elvégzése után mindketten visszatértek a konventhez vagy káptalanhoz, és a helyszínen fölvett jegyzetek alapján (melyet általában a parancslevél hátlapjára, széleire írtak) beszámoltak eljárásukról, majd a hiteleshely oklevelet állított ki, amelyet elküldött a megbízónak. ${ }^{589}$

\footnotetext{
${ }^{586}$ A létszámhiányt Pálfi István a harmadik impedimentumként sorolta fel, lásd 454. sz. jegyzet. Az 1649-1653 közötti időszakból fennmaradt egy 51 f. terjedelmü ívfüzet, amely a gyulafehérvári káptalan előtt felvett bevallások signaturáit tartalmazza. Ennek alapján megállapíthattuk, hogy a káptalani hiteleshelyet ekkor még hetente felkeresték. Lásd MOL F2. 52. doboz.

${ }^{587} \mathrm{KmProt}$ XXXVIII. p. 9-11. Az ügyfelek jelentős része ügyvédeket vallott, tiltakozott, vagy oklevele protocollumba való másolását kérte. Csak ritkán keresték fel a konventet birtokok adásvétele, zálogosítása vagy egyezségek írásba foglalása miatt.

${ }^{588}$ Kumorovitz: A leleszi konvent 3.; Bilkei: A zalavári és a kapornaki konventek 104-107.; Dreska Gábor: Egyházi intézményeink közhitelü iratkiadásának középkori emlékei. In: 700 éves a közjegyzőség Magyarországon (szerk. dr. Rokolya Gábor) Bp., 2008. 35-40.

${ }^{589}$ Sipos: Kolozsmonostor 41.
} 
Az ún. külső hiteleshelyi munka a konvent azon tevékenységi köre, amely a kora újkorban jelentős változásokon ment át. Először is megszűnt az erdélyi hiteleshelyek e területen tapasztalható viszonylagos „egyeduralma", a hiteleshelyek világi alapon való újjászervezése után iktatásokat, tanúvallatásokat, határjárásokat stb. gyakrabban végeztettek vajdai emberekkel (a kancelláriából kiküldöttekkel vagy helybéliekkel), a vármegyékkel vagy ítélőmesterekkel. A középkorihoz képest megfogyatkozott létszámmal müködő „világi” hiteleshelyek nem is lettek volna képesek ellátni a külső munka teljes körét, az előbbiekben folsorolt megbízásokat a XVI. században még viszonylag gyakran, a XVII. közepétől azután egyre ritkábban teljesítettek. Ez a folyamat annak is a következménye, hogy az elvégzendő külső hiteleshelyi tevékenység jellege is átalakult, nagyjából Bethlen Gábor uralkodásától kezdve a requisitorok a fejedelem megbízottjaiként egyre gyakrabban láttak el olyan feladatokat, amelyekre korábban nem találtunk példát: uradalmak urbáriumait állították össze és az udvarbírákat iktatták be, a székely hadakat írták össze (lustrák), várőrségek esküjét foglalták írásba, stb. Összefoglalva, a levélkeresők a fejedelem fizetett hivatalnokaiként jártak el a reájuk bízott állam- és birtokigazgatási teendőkben, és ezekről jelentéseket írtak megbízójuknak. Az alábbiakban csak azokat a tevékenységi köröket vesszük számba, melyek a fejedelemség kori konventet nagyban megkülönböztetik a középkoritól, tehát a külső hiteleshelyi munka tárgyalásakor is a változásokra fektetjük a hangsúlyt. A konvent fejedelemség kori executiós tevékenységét két csoportra osztva tárgyaljuk úgy, hogy elkülönítjük a magánügyfelek érdekében folytatott végrehajtásokat a fejedelem megbízottjaiként teljesítettektől.

Mielőtt azonban rátérnénk a jelentések tárgyalására, ki kell térnünk Pálfi beadványának egyik nehezen értelmezhetô megállapítására, amely a konvent külső hiteleshelyi tevékenységére vonatkozik. A levélkereső 1655-ben kelt beadványában az Articulus rendelkezései szerint „az legitima executio, mely ez hivatalnak propriuma tolláltatott". ${ }^{590}$ Véleményünk szerint az Articulus az 1653-ban elfogadott és nyomtatásban is megjelent Approbatae Constitutiones lehetett, amely lényegében a felülvizsgált törvénycikkek gyüjteménye. ${ }^{591}$ Ennek szövegében azonban nem találtunk utalást a hiteleshelyek executiós tevékenységének megszüntetésére. Sőt a káptalanokra vonatkozó részben megengedik, hogy „authoritások légyen pedig minden legitima executiókra, mindazonáltal nem excludáltatván mellőlök és kivülöttök is, a dolognak mivoltához és eddig observál-

\footnotetext{
${ }^{590}$ Bővebben lásd Pálfi beadványának 4. pontjánál. A tolláltatás eltöröltetést, megszüntetést jelentett. Vö. SzT XIII. 364-365.

${ }^{591}$ „revisioni collectorum articulorum opera” (EOE XI. 170). Az Approbaták nyomtatására vonatkozó rendeletek is articulusokat emlegetnek: „Az articulusoknak nyomtatását már jobbrészent elvégezvén [...]". Vö. EOE XI. 172.
} 
tatott usushoz képest egyéb legitimus executorok is". Ezt a rendelkezést utóbb újból megismétlik: „statutiókat és külső executiókat penes regium peragálhatnak". ${ }^{592}$ A Pálfi és az Articulus szövege közötti nyilvánvaló ellentmondásra nem sikerült magyarázatot találnunk. Tény az, hogy az Approbaták megjelenése után összeállított konventi jegyzőkönyvekben, illetve az általunk átnézett konventi és családi levéltári anyagban nem találtuk nyomát az executiós tevékenységnek. ${ }^{593}$ Pálfi panaszlevelének talán éppen az lehetett a kiváltó oka, hogy a törvényi rendelkezéssel ellentétben valóban nem használták a káptalanokat végrehajtásra.

\section{A magánügyfelek érdekében folytatott külső hiteleshelyi tevékenység}

A kolozsmonostori konvent a kora újkorban is végrehajtotta az érdekelt ügyfél által kieszközölt hatósági (fejedelmi) mandatumokat. A fejedelmi kancellária általában a jószágok adományozásával egy időben iktatóparancsot is kiállított, melyet a kijelölt vajdai (fejedelmi) emberekhez vagy valamelyik hiteleshelyhez intézett. A korszak jogfelfogása szerint az ingatlan javak birtoklásának továbbra is elengedhetetlen feltétele volt az iktatás végrehajtása. Miután vélhetően az ügyfél eljuttatta a konventhez a parancslevelet, az kiküldte valamelyik tanúbizonyságát (testimonium), ebben a korszakban az egyik requisitort, akinek jelenlétében a vajdai/fejedelmi emberek egyike végrehajtotta az iktatást. Nem tudtuk eldönteni, hogy volt-e valami rendszer abban, hogy éppen melyik levélkereső szállt ki az iktatások végrehajtásához, de arra nézve rendelkezünk adatokkal, hogy a kiküldött tanúbizonyság egyik konventi társa által összeállított instrukció alapján hajtotta végre a mandatumot. 1620-ban Demeter János levélkereső feltehetően Szőlősi István instrukcióját követte egy Kolozs vármegyei iktatás során. ${ }^{594} \mathrm{~A}$ végrehajtáskor összehívták az illető birtok szomszédait, és három napig a helyszínen maradtak, hogy az esetleges

\footnotetext{
${ }^{592}$ AC 203.

${ }^{593}$ Arról viszont van adatunk, hogy 1657-ben Szőlősi Gábor requisitor előtt tette le az esküt a szamosújvári ôrség lásd EOE XI. 329. Az executiók végzésének kérdése tehát továbbra is fennáll. Megjegyzendő, hogy az 1669-ben megalkotott Compilata Constitutiók cikkelyei már csak a káptalanok levéltári feladataival foglalkoznak, az executiós tevékenységről egyáltalán nem esik szó. Vö. Compilatae Constitutiones. In: 1540-1848. évi erdélyi törvények (Ford. és utalásokkal ellátták Kolosvári Sándor és Óvári Kelemen). Bp., 1900. 328.

${ }^{594}$ MOL F25 (Miscellanea), f. 452. Az instrukció töredékes szövege az alábbiakat tartalmazta: "Arra szorgalmatos gondot kel viselni, hogy az vicinusokat és commetaneusokat convocaliak solemniter egy parancsolattal, harmad harmadmagokkal az bírákat, és mikoron [?] az executiohoz akarnak kezdeni, megh kel tudni ha minden faluból jelen lesznek az vicinusok. Az után megh kel jelenteni elöttök mi okon convocaltattanak."
} 
ellentmondásokat fölvehessék. ${ }^{595}$ Olykor előfordulhatott, hogy valamilyen okból nem tudták a helyszínen végrehajtani az iktatást. 1584-ben például a fejedelem parancsára Wesselényi Ferencet vezették be a hadadi vár és tartománya birtokába, a vajdai embert és a requisitort azonban nem engedték be a várba, ezért az iktatást a hídon hajtották végre. ${ }^{596}$ Arra is volt eset, hogy az iktatást végző fejedelmi kiküldött - elfoglaltságai miatt - nem tudott a hiteleshelyen jelentést tenni, ilyenkor relatióját írásban is beküldhette. ${ }^{597}$ A kiküldött levélkereső magával vitte a mandatumot, ${ }^{598}$ és általában ennek margóján, illetve hátoldalán fogalmazta meg a jelentés szövegét, a középkori gyakorlathoz viszonyítva nem csak rövid jegyzetek formájában, hanem a kiállítandó jelentések szinte teljes szövegét a hátlapra írta. ${ }^{599}$ Ezeket a mandatumokat aztán elhelyezték a konvent levéltárában, ezért csak meglehetősen ritkán fordult elö, hogy a birtokiktatásról kiadott jelentést protocollumba másolták (ha viszont igen, akkor a jegyzőkönyvbe a kiszálló levélkereső vezette be).

A requisitorok hivatalba állítása után, vélhetően 1576-tól újra beindult a konvent külső hiteleshelyi munkája, az általunk ismert legkorábbi iktatás azonban csak 1577 júniusából maradt fenn. Ekkor a konventi levélkeresők pergamenre írott privilégiumukkal bizonyították, hogy Báthory Kristóf vajda 1577. április 29-én kelt parancsára kiküldték a vajdai ember mellé Balásfi Ambrus requisitort, s ők a konventhez visszatérve jelentették, hogy bizonyos Közép-Szolnok vármegyei jószágokat Gyulaffi László részére iktattak. ${ }^{600} \mathrm{~A}$ jelentésben teljes szövegében átírt mandatum vajdai emberekként kancelláriai íródeákokat és környékbeli nemeseket sorolt fel. Az oklevél díszes kiállítása egyértelmüen a fejedelmi kancellária hatására utal (a levélkeresők tekintélyes része valamelyik fejedelmi kancelláriáról került a hiteleshelyre). Az iktatásokról kelt jelentéseket az erdélyi hiteles-

${ }^{595}$ Vö. Bilkei: A zalavári és kapornaki konventek 104-105.

${ }^{596}$ KvNLt, Wesselényi cs 1t, 4. doboz (a kolozsmonostori konvent 1627-ben kelt átirata). A vajdai ember és a levélkereső „dum ad faciem eiusdem castri ingredi voluissent egregius Joannes Harangy, servitor generosae et magnificae dominae Annae Revai, cum caeteris eiusdem dominae familiaribus, ex voluntate eiusdem dominae et etiam in persona generosae puellae Susannae Jakchi, filiae quondam magnifici Balthasaris Jakchi de Kusali, ipsos ingredi non permisissent sed pro foribus eiusdem castri videlicet in ponti consistens" hajtották végre az iktatást. Vö. Papp László: A birtokba-iktatás 376.

${ }^{597} 1649$ decemberében például Pálfi István egyedül tett jelentést egy iktatásról, minthogy a fejedelmi emberek a közügyekben való elfoglaltságaik miatt személyesen nem tudtak a konventhez járulni, és írásban küldték el a relatiót. Lásd KvNLt, Kornis 1t, fasc. 10, 53.

${ }^{598}$ 1603-ban Basta György parancsára iktat a konvent Alsójárán úgy, hogy a parancslevél is a kiküldötteknél van (in specie apud se habitarum), lásd KmProt XV. 232 ${ }^{\mathrm{v}}-233^{\mathrm{r}}$.

${ }^{599}$ Lásd MOL F25 (Miscellanea), f. 226. és további példák ugyanott.

${ }^{600}$ KvNLt, Függőpecsétes oklevelek gyűjteménye (Documente cu peceți atârnate), nr. 127. 
helyek általában függőpecsétes oklevélként adták ki, ${ }^{601}$ ha azonban ellentmondást tett valaki, az erről kelt relatiót zárt alakban küldték el. Vélhetően így történt ez abban az esetben is, ha az iktatást ítéletlevéllel rendelték el és mégis tiltakoztak, ekkor azonban az ítéletlevelet a konvent pecsétföjével (capite sigilli) megerősítve visszaküldték. A vármegyék vagy vajdai emberek által végrehajtott iktatásokat viszont clausaként küldték vissza a kancelláriára, ${ }^{602}$ ahol a fejedelem nevében kiállított privilégiumba foglalták. A requisitorok általában nagyon ügyeltek arra, hogy jelentésükbe ne csússzon hiba, ha azonban mégis tévedtek, a károsult ügyfél mandatum correctoriummal az oklevél kijavítását és újbóli kiállítását kérhette. ${ }^{603}$

${ }^{601} \mathrm{KmProt}$ VII. $79^{\mathrm{r}}-80^{\mathrm{r}}$; KmProt XXIX. $114^{\mathrm{r}}-115^{\mathrm{v}}$ (további példák a konvent Miscellanea anyagában). Vö. ErdKápJkv VIII/1. 490., 495., 506., 587., 601., 640., 704., 744., 789., 800. sz.

${ }^{602}$ ErdKápJkv VIII/1. 337. sz.

${ }^{603}$ 1588-ból maradt fenn a konvent jelentése arról, hogy fejedelmi parancsra a mandatumban felsorolt hibákat (mások mellett a keltezésekben is) kijavították. Lásd MOL F25 (Miscellanea), f. 255. Olykor az is előfordult, hogy a konvent írásban figyelmeztette az ügyfelét a statutoriában előforduló ellentmondásokra. Így tett például Pálfi István 1650-ben, mikor levelében Kornis Ferenc figyelmét hívta fel az eljárás során elkövetett hibákra: „Jóllehet valóba igyekeztem nagyságodat levelemmel requirálni és majd minden nap küldöttem az nagyságod szállására is, ha nagyságodnak emberét találhattam volna, de szerencsétlen voltam, mert sem az georgyffalvi gondviselőt, se mást valakit nem kaphattam. Most azért Nylas uramtól akarám [?] nagyságodnak jelenteni. Az Gyekei relatoriat elkészíttettem, nagyságodnak megh is küldöttem. Az SzentMartonit is megh minutáltam, de megh nem írhatam, mivel abba is difficultasokat találék, mellyet hogy eléb eszembe nem vöttem, oka, mert az SzentMartoni statutoriat innét mingyárt oda küldöttem, és avval convocaltak Gyekebe az embereket. Gyekeből esmét ugyan azt vitték Zentmartonba s avval convocalták. SzentMartonból esmét ugyan azt vitték Gyrotba, hogy Hesdatra convocalliák az embereket, és így absolute nem percurralhattam. Úgy vagyon azért, hogy az statutorianak első részét megh tekintvén, láttam, hogy inscriptioban vagyon az a jószágh, quaestio is lőn felölle, hogy ha egészen kell-e statuálni? De Szigethi uramék azt állatván, hogy sem Vesseleni uram, sem nagyságod egészen nem bírta, per hoc most is ugyancsak azt a részt kell statualni, az mely nagyságod kezénél volna, ő kegyelmek úgy statualták az másfél ezer forint summáigh. Ez penig megh nem álhat talám, mert illy defectusokat látok benne:

1. Az statutoriaban az falu egészen vagyon írva, hogy nagyságod egészen bírta. Azt állatyák penig az tisztek, hogy csak portiót bír ott nagyságod, mi penig azt statualtuk, amit ott nagyságod bírt, úgy mint portiot. Ha azért egészen vagyon az falu, az donatio mutattja megh, és így káros nagyságodnak.

2. Az statutorianak utolljába azt írták, hogy perpetuo possidendo statuálljuk. Az inscriptios jószágot penigh, és kiváltképpen az fiscalist, perpetuo jure nem statuálhatni, articulus vagyon rólla. Mi is penigh az summának depositiójáigh statuáltuk.

Ezek nagyságodnak károsok. Ha azért defectus vagyon az dologban, job restatuálni, hogy sem mint kárt tenni. Én azért nem írtam megh az relatoriat az nagyságod resolutiójáigh. Nagyságodat penig kérem, hogy nehézsége ne legyen ezért, hogy jelentem, mert az relatoriában lehet az defectus, kit hogy előb eszembe nem vöttem, megh írtam az okát. Bíztam is az levélnek tenorához, de az mint eszembe veszen novitius deák is fogta írni. Ím magát is az statutoria levelet nagyságodnak el küldöttem, signaltam is valamit rajta, ha correctio kívántatik bene, az oda küldött relatoriat mikor apertaltattja nagyságod, azt is corrigalhattják. Ha penig ugyan restatualni kelletik s nagyságod difficultalna az újólagh való költést, inkáb magam fogadok lovakot és ki menvén peragalom, csak hogy informálljon az dologh felőll, és az 
A konventi requisitorok tanúskodhattak egy-egy birtok határainak megállapításánál is. A fejedelmi mandatum alapján, a vajdai emberrel együtt kiszálltak a vitatott határhoz, ahol - a szomszédok jelenlétében olykor régi határmegállapító oklevél segítségével, ${ }^{604}$ új határjeleket állítottak fel. Gyakran megesett, hogy valamelyik fél a határok helyzetét sérelmesnek találta, és tiltást tett. ${ }^{605}$ Ilyenkor a vitát csak hosszas határperrel lehetett eldönteni. ${ }^{606}$ Ha nem volt ellentmondás, a határok megállapításáról is függőpecsétes oklevelet állítottak ki. ${ }^{607}$ Egy-egy határjárás foganatosítása az igénylő félnek tekintélyes összegbe kerülhetett, minthogy a törvényesen megszabott illetékeken és ellátáson kívül az exequáló többet is követelhetett. ${ }^{608}$ Pálfi István requisitor például 1648-ban levélben egyeztetett a Máramaros vármegyei alsóapsaiakkal egy határjárás menetéről és áráról. ${ }^{609} \mathrm{Az}$ alsóapsaiak elégedettek lehettek Pálfi ajánlatával, mert a kije-

statutoriat külgye megh. Ha penig az statutio jól lött, ugyan nem concordal az statutoriaval, mert mi nem egész falut, hanem portiot és nem perpetuo jure, hanem inscripticio statuáltuk. Ezekről az nagyságod informatiot alázatoson várván, tarcsa megh Isten nagyságodat jó egésségben. Datum Claudiopoli, die 7 Januarii, anno domini 1650.

Spectabilis ac magnificae dominae vestrae humillimus servus Stephanus Palffy manu propria" (ENMlt a KvNLt-ban, Kornis lt, nr. 23. 1650-1741).

${ }^{604}$ 1640-ben Hosszúmező mezőváros (Máramaros vm) határait egy 1456-ban kelt oklevél alapján járják be. Lásd KmProt XXX. 64-65 .

${ }^{605} 1640$. október 29-én a hosszúmezei határjárást végző homo regius, Pogány Menyhárt máramarosi alispán és Pécsi János requisitor magyar nyelvü testimonialis levelet állított ki a szomszédok tiltakozásairól, illetve a hosszúmezeiek erre kelt válaszairól. Vö. KmProt XXX. $65^{\mathrm{v}}-66^{\mathrm{r}}$.

${ }^{606}$ Sipos: Kolozsmonostor 42.

${ }^{607} \mathrm{KmProt}$ XXXIV. $54^{\mathrm{r}}$ elötti számozatlan lapokon.

${ }^{608}$ EOE V. 504.

${ }^{609}$ „Szolgálatomat ajánlom kegyelmeteknek, nekem jó akaró uraimnak. Isten kegyelmeteket kívánsága szerent való sok jókkal álgya megh. Vevén az kegyelmetek írását újabban ide bocsátott emberétől, értem az kegyelmetek kívánságát. Azért az dologról mint discurráltunk és mit deliberáltunk, im meghírtam. Innét az megh indulásnak módgyát rendeltük ad diem 15. presentis mensis Junii, ha akkorra kegyelmetek beküld, úgy hogy kegyelmetek ad diem 22. Junii certificaltassa az vicinussokat. Az procuratorral én eleget discurraltam, úgymint Szamoskeozi Mihály urammal. Ő kegyelme az egy útra ötven forintot, f. 50 és egy jó paripát kéván, és hogy ha kegyelmetek arra reá megyen, csak Desre kell akkor küldeni eleibe egy lovat az melyen be mennyen, mert ott akkor szék leszen, neki ott kell lenni, onnét egyenesen csak Banyara megyen által. Ez eddigh kegyelmeteken áll. Az én dolgom esmét más kárban áll, mert ott az procurator most keveset szolgál, hanem jövendő az ő szolgálattja: úgy vagyon, hogy ha maga jelen leszen az executioba sokkal jobb és könnyebb leszen az causat agalni annak idejében. Hanem ott mindent én cselekeszem, jóllehet most ha contradicalni fognak, cessalnunk kell és evocalvan az adversa parsot az terminuskor, az mi relatoriank mellet procedalhat az procurator. Az én fizetésem mi legyen, kegyelmetek megh tudhattja az Vissai határjáráskor mit attak. Ide be az exmissiojert f. 12. Az oda való járásomért és az executioról való relatoriaert attak conventiokeppen f. 40. Ezen küvül mindenik falu egy egy gyermek lovat, rókát, nestet honorariumba, mellyet ő kegyelmektől én is jó néven vöttem, s jól is ügyekeztem szolgálni. Hogy ha azért kegyelmetek mindezekre reá megyen, Isten egésségben meghtartván, az indulás megh lehet. Az is penigh illy formán, hogy kegyelmetek ne külgyön bár többet, 
lölt időpontban a határjárás meg is történt, de a szomszédos szlatinaiak élőszóban és írásban tiltást tettek. ${ }^{610}$ Ha viszont nem volt ellentmondás, a határjárásról a konvent privilégiumot állított ki. ${ }^{611}$

Néhány adat alapján, melyet egy parancslevél versójára jegyeztek, a konvent határjárások elvégzésénél tanúsított hatékonyságára is következtethetünk. 1650-ben a Segesvár városa és a Bethlenek birtokai (Keresd, Segesd, Szentlászló) közötti határt állapította meg Pálfi István levélkereső. A mandatumot november 10-én vették kézhez, de a szomszédok értesítése már korábban, október utolsó napján megtörtént. A határokat november 14-én járták be Árkosi Mihály kancelláriai íródeák és az említett requisitor, a királyi ember pedig jelentését november 20-án tette meg („,relatio per eundem regium facta est in Conventu coram nobis"). ${ }^{612}$ A fejedelmi kiküldöttet a határjárást igénylő fél kérte fel a kiszállásra és általában költségeit is megtérítette. Petrovai Jakab, Máramaros vármegye főszolgabírája éppen amiatt tiltakozott a konventnél 1640-ben, mert miután Pálfi István társaságában Borsa, Felsővisó és Középvisó határait bejárták, tehát a határjárást az ország szokása és törvénye szerint végrehajtották, a birtokok lakosai nem igényelték jelentését, és a végrehajtás költségeit sem térítették meg, habár ô még készen áll jelenteni a konvent előtt. ${ }^{613}$

A perek folyamán az oklevelekkel nem bizonyítható tényeket hiteles tanúk vallomásai alapján lehetett igazolni. A peres eljárásokkor a fejedelemség korában is a bizonyítás eszközeként használták az egyik peres fél részére készült egyszerű (inquisitio simplex), illetve mindkét peres fél érdekében végzett köztudományvételeket (inquisitio communis). ${ }^{614}$ Amikor

\footnotetext{
hanem egy jó járó paripát, csak vezetéken, az mellyen vizeken, hegyeken járhassak, leszen nekem arra való szerszámom, nyergem etc. Minthogy penig beteges állapotom miatt paripán annyi földre nem mehetek, én az magam szekeremen akarok meghindulni, lovakat az szekér eleibe itt Coloswarat találni, én az mint jutalmasban lehet meghalkuszom velle. Négy ló könynyen elbír, az út penig Visk felől leszen. Négy vagy öt lovas keserő ember is legyen, az kik az útat tudgyák jól. Mind ezekre ha kegyelmetek reá megyen, mikor kegyelmetek beküld, pinzt is külgyön kegyelmetek. Ha penig kegyelmetek az megh írt napra emberét nem bocsáttja ide, azután engemet itthon nem találnak, az feriak is eljönek, őszre Szent Márton nap felé halad ez dologh, az mikor szinte az terminusnak ideje lészen. Én mindazáltal mindenben az kegyelmetek könnyebségét keresem fel. Ez mellett kérem kegyelmeteket nagy bizodalommal, akkorra ha beküld kegyelmetek fogasson valami szép halakat, pisztrángot, galóczát, etc. Az Colosvari bíró nekem atyámfia, szintén akkor lészen az fiának menyegzeje, az kegyelmetek emberségével had tisztelkedgyem ő kegyelmének, igen kedvesen veszem kegyelmetektől. Ezzel Isten tarcsa megh kegyelmeteket jó egésségben" (MOL F25, Miscellanea II., f. 345).

${ }^{610} \mathrm{KmProt}$ XXXII. $19^{\mathrm{r}}$.

${ }^{611} \mathrm{KmProt}$ XXXIV. $54^{\mathrm{r}}$ előtt, számozatlan lapokon.

${ }^{612}$ Uo.

${ }^{613} \mathrm{KmProt}$ XXVIII. $169^{\mathrm{v}}$.

${ }^{614}$ Ezekről bővebben lásd Bogdándi Zsolt: Tanúvallatások a XVI. század második feléből. Az erdélyi hiteleshelyi jegyzókönyvek forrásértékéröl. In: Történeti tanulmányok XII. A Debreceni Egyetem Történeti Intézetének kiadványa (szerk. Takács Péter). Debrecen, 2004. 25-31.
} 
a konventnél ${ }^{615}$ egyszerü tanúvallatásokat tartottak, általában az eljárást igénylő fél vitte a helyszínre a tanúkat, és biztosan ő fedezte az executióval járó költségeket is. Így történt ez a köztudományvételek esetében is, ilyenkor azonban valamelyik requisitor egy fejedelmi kiküldöttel szállt ki. A tanúk beidézése és a kiküldöttek honoráriuma elég nagy terhet róhatott a felekre, a kolozsváriak tiltakoztak is, amikor hiába áldoztak a requisitor és a bevallók Kolozsmonostorra való előállítására, minthogy a másik fél a tanúit nem küldte el. ${ }^{616}$

A tanúvallomások fölvételének és a jelentések kiállításának gyakorlata a középkorihoz képest nem sokat változott. A tanúvallatást elrendelő ítéletleveleket hasonlóképpen, pecsétfővel megerősítve küldték vissza a fejedelemhez, mint azt korábban tették, ${ }^{617}$ és a relatiókat a fejedelemség korában is a helyszínen fölvett tanúvallomások alapján állították össze. Ezek a jegyzetek azonban már anyanyelven készültek, ${ }^{618}$ és a kiadványokba is így kerültek. Talán emiatt is nő meg a jelentések terjedelme, olykor több tíz oldalon át sorakoznak fel a tanúk vallomásai. Bizonyára könnyebb lehetett magyarul megfogalmazni vagy rögzíteni a tanúk által mondottakat.

A bizonyításnak szintén gyakori módja volt a magyar joggyakorlatban már a XIV. századtól kezdve az eskütétel. Ennek ceremóniája általában a hiteleshelyek előtt ment végbe. A kolozsmonostori konvent fejedelemség kori protocollumaiban földesküre nem találtunk példát. ${ }^{619}$ Annál többször fordult elö, hogy egy-egy per folyamán a fejedelem parancsára a konvent előtt tettek esküt. Igy 1591 februárjában Tamásfalvi Dénes - két nemes eskütársával együtt - arról esküdött meg, hogy az általa fogságba vetett fejedelmi jobbágy nem az ő hibájából vesztette életét. ${ }^{620}$ Arra is találtunk

\footnotetext{
${ }^{615}$ Nehéz eldönteni, hogy ez a fejedelemség korában mit is jelent. Talán az egyik levélkereső házánál vagy a városi tanácsháznál vették fel a tanúk vallomásait.

${ }^{616} \mathrm{Az}$ eset 1619-ben történt. A konvent jelentéséből kiderül, hogy a fejedelem köztudományvételt elrendelő parancsára kiküldték Szőlősi István requisitort a kijelölt regius mellé Zambo Mihály kolozsmonostori udvarházához, de ott csak a kolozsváriak tanúi jelentek meg, a felperes Kamuthi Farkas senkit sem küldött, habár üzentek neki a kolozsmonostori kastélyba. A kolozsváriak emiatt a helyszínen tiltakoztak, minthogy ők tanúikat az ítélőszéki parancs szerint elóállították, és nem kis költséget áldoztak erre („,hominem conventualem et universos testes non levi sumpta et labore convocassent"). Lásd KmProt XX. 128v-130v.

${ }^{617}$ Szekularizáció előtti példák: KmJkv II. 5237., 5241. sz. Pecsétfővel való megerősítés említései a fejedelemség kori tanúvallatásokban: KmProt VIII. $5^{\mathrm{r}}-7^{\mathrm{r}}, 13^{\mathrm{r}}-15^{\mathrm{v}} ; \mathrm{KmProt}$ XX. $130^{\mathrm{v}}$; KmProt XXIX. 25 $29^{\mathrm{r}} 2^{\mathrm{r}}$.

${ }^{618}$ A leleszi konvent kiküldöttje is magyarul írta jegyzeteit az 1560-as években lásd http:// nyelvemlekek.oszk.hu/adatlap/leleszi_konvent_hiteleshelyi_feljegyzese

${ }^{619}$ A földesküről értekező Varga János szerint a földtulajdonosok körében utoljára a XVI. század harmincas éveiben említik ezt a szertartást. Vö. Varga János: Földeskü - Határviták lezárása a 12-15. században. Székfoglalók a Magyar Tudományos Akadémián. Bp., 2000. 14-15. A források arra utalnak, hogy Erdélyben a XVI. század végén a szász székekben még szokásban volt a határviták földeskü alapján való eldöntése. Lásd ErdKápJkv VIII/1. 918. sz.

${ }^{620} \mathrm{KmProt}$ VIII. $41^{\mathrm{r}}$.
} 
példát, hogy az eskütételt valamelyik peres fél megakadályozta. 1619-ben a konventi requisitorok a fejedelem parancsára jelentették, hogy megjelent előttük („,coram nobis in dicta sacristia Beatae Mariae virginis") Becsiki Anna, aki készen állott arra, hogy harmadmagával esküt tegyen, de az alperes a fejedelem tiltó levelével ezt megakadályozta. Ezért az asszonyt eskütársaival együtt hazaküldték, az egyik requisitor pedig - a fejedelem mandatuma értelmében - elment Anna asszony szállására, és megidézte. ${ }^{621} \mathrm{Az}$ eskütétel nem maradt el Prépostvári Zsigmondné Szécsi Katalin esetében, aki bizonyos oklevelek ügyében jelent meg 1618-ban eskütételre a requisitorok előtt. Bevallása szerint ő már korábban letette az előírt esküt, melynek szövegét be is mutatta, a levélkeresők átírták, felolvasták, az aszszony pedig ennek alapján újból esküt tett. ${ }^{.22}$

Természetesen még sokféle ügyben eljártak a konventi requisitorok, de most csupán olyan executiókra térünk ki részletesebben, melyekhez hasonlót a középkori gyakorlatban nem találtunk. Az egyik jelentés 1639-ben kelt, és a jegyzőkönyvi másolata fölé írott cím szerint „revisionalis super agritudine" kategóriába sorolható. Arról szól, hogy két levélkereső fejedelmi utasításra kiszállt Rozsás István Kolozsvár fôterén levő házához, ahol megállapították, hogy az említett személy a köszvény miatt (,gravi morbo podagrico et chiragrico pressum, decumbentem") semmiképpen sem tud útra kelni. Azt nem tudjuk, hogy miért akarta a fejedelem Rozsást útnak indítani, de egy másik esetben az is kiderült, hogy hova és miért nem akart elmenni a bizonyságlevelet kérő ügyfél. 1645-ben a requisitorok idősebb Vicei Péter kolozsvári házánál állapították meg, hogy Viceit a házastársi eskü arra kötelezi, hogy - a fejedelem hadba szólító parancsa ellenére halálosan beteg felesége mellett maradjon. ${ }^{623}$

Egy másik executiót azért tartunk említésre méltónak, mert a megintésre (admonitio) tett választ írásban terjesztették elö, és annak magyar nyelven írott szövegét a jelentésbe foglalták. 1631-ben történt az eset, amikor Rákóczi György fejedelem parancsára Pálfi István requisitor a kolozsvári tanácsházhoz ment, ahol megintette a főbírót, a királybírót és az esküdteket, hogy Hatvani István javaiból adják ki az exponenseket megillető részt. ${ }^{624}$

\footnotetext{
${ }^{621}$ KmProt XX. 119v-122r.

${ }^{622}$ KmProt XVIII. $48^{r}$.

${ }^{623}$ Vicei Péter a helyszínen azt vallotta, hogy maga helyett a többi városi nemessel együtt elégséges számú embert állított hadba, lásd KmProt XXXIV. 71v.

${ }^{624} \mathrm{KmProt}$ XXVIII. 39v.
} 


\section{A konvent területi hatásköre a jelentések alapján}

Minthogy a konvent protocollumaiba csak ritkán másolták be a külső hiteleshelyi tevékenység során keletkezett jelentéseket, csupán gyér források alapján tudjuk valamennyire felvázolni azt a területet, ahova a requisitorok általában kiszálltak. Egyébként is a középkori helyzethez képest az erdélyi hiteleshelyek executiós tevékenysége leszűkült (1654-től talán meg is szűnt); a végrehajtásokat már mások is (vármegyék, vajdai emberek) végezhették. Az executiót igénylő ügyfél tehát nagyobb mértékben válogathatott, mint korábban tehette, vélhetően kényelmi és anyagi szempontok döntötték el azt, hogy kihez fordult. Valószínúleg szintén a földrajzi közelség játszott közre abban, hogy a konvent külső hiteleshelyi tevékenységének helyszínei a környékbeli vármegyékben található birtokok, így a törzsterület Kolozs, Torda, Doboka megyékre terjedt ki, de elvétve távolabbi vidékekre, például Máramarosba is kiszálltak. A konvent területi illetékességében tehát semmilyen szabályszerúség nem figyelhető meg, annak ellenére, hogy az 1575-ben megszövegezett instrukció a régi határokhoz való igazodást rendelte el. ${ }^{625}$ Valamelyik levélkereső meg is jegyezte, hogy „most semmi efféle rendtartás nincsen, hanem aki hozzá érkezik, menten megy". ${ }^{626}$

\section{A requisitorok a fejedelem szolgálatában}

Úgy tưnik, hogy már Bethlen Gábor idején megkezdődött az a folyamat, amely az idősebb Rákóczi fejedelemségétől kezdve fokozottan követhető nyomon, nevezetesen a levélkeresőknek a fejedelmi birtokpolitikában, a fiskális uradalmak igazgatásában való igénybevétele. A konvent ilyen jellegű terhelése természetesen zavarokat okozott a "hagyományos” hiteleshelyi tevékenységben, minthogy létszámhiány esetén nem állíthatták ki jogszerúen az igényelt okleveleket.

Arról, hogy miben állott és hogyan folyt le a gyakorlatban a levélkeresők fejedelmi utasításra végzett munkája, leghitelesebben az ezekben az ügyekben váltott kevés fennmaradt levél tájékoztat. Amikor "hivatalos” ügyekben jártak el („,ex speciali praelibati domini principis mandato in negotiis eiusdem domini principis insudando absentibus"), ${ }^{627}$ a fejedelemtől salvus conductust kaptak, melyben az útjába eső hatóságokat postaló, esetleg fogat adására és cseréjére, továbbá szállás és ellátás biztosítására

${ }^{625}$ „Hogy a conventnek amennyire régen határuk volt, míg járhassanak az országban és Magyarországban executioban, addig járhassanak, tovább ne." Lásd Sunkó: A Gyulafehérvári Káptalan 79-80.

${ }^{626}$ Uo. 80.

${ }^{627}$ KmProt XXVII. 71 ${ }^{\text {r }}$. 
kötelezték. ${ }^{628}$ A megbízást végrehajtó requisitor e menlevéllel felszerelkezve levélben értesítette az executio helyszínéhez közeli hatóságot (várost, vármegyét, falusbírákat stb.) arról, hogy érkezése mikorra várható és a végrehajtás során mire lesz szüksége. ${ }^{629}$

A kolozsmonostori levélkeresők fejedelmi szolgálatban végzett tevékenységeinek jelentős része a kincstári uradalmak igazgatásához kapcsolódik. ${ }^{630} \mathrm{Az}$ inskribált fiskális jószágok visszavételekor például általában úgy jártak el, hogy a fejedelem valamelyik tisztségviselöjével a konventhez küldte a zálogösszeget, melynek átvételéről a jószágot visszaszolgáltató felek nyugtát adtak, ${ }^{631}$ vagy pedig maguk a requisitorok szálltak ki a birtokhoz, hogy kínálják fel az inskripciós összeget. ${ }^{632}$ Olykor tehát igazi kincstárként működött a konvent (a levélkeresők otthona vagy az a városi ház, melyben a levéltárat őrizték); a hiteleshelyen néha jelentős összegeket helyezett letétbe a fejedelem, 1636-ben például 9000 Ft-ot, a kolozsmo-

${ }^{628} 1641$. július 28.: „Ez levelünk mutató Colosmonostori edgyk káptalan hívünket kelletvén szükséghes dolghaink véghett Közép Szolnok vármegyében, Nagy Dobában kibocsyátanunk, parancsiolljuk minden rendbéli híveinknek kegyelmesen, ez levelünket látván adgyanak mindenütt postalovatt s szekerett alája, s békével bocsyátván ghazdálkodgyék is illendő képpen mind menett, s jövett nekie." Lásd MOL F25 (Miscellanea II.), f. 251.

${ }^{629} \mathrm{Az}$ executiók gyakorlatára vonatkozóan fontos adalék Pécsi János levélkeresőnek 1635. május 4-én Beszterce városához intézett levele: „Minden jóval lássa Isten kegyelmeteket kedve szerént. Az mi kegyelmes urunk ű nagysága bizonyos magára nézendő dolog felől való inquisitiora engemet ki bocsátván, holnap Lekentzere megyek, it Tekeben ma dulgomat végezvén, keg[yel]meteket annak okáért intem az ű nagysága nevével, hogy vevén az ű nagysága mandatumit mindgyárast az alsó processusabúl és az Szereten innen való részébủ[l], három esztendőtül fogva való és az mostani grébeket holnapra, pénteken 10 órára, sub oneribus 64 florenorum, az akkori esküttekel és minden [...] emberekkel Lekentzére gyüjtvén, két polgár társait regiusoknak oda bocsátván, az inquisitiot continualván ott, annak utánna, az Szereten túl való részét az szerént Szombatra 8 órára Beseniöbe gyüjtvén, ott is késedelem nélkủl az inquisitiot elvégezvén, keg[yel]metek városába is bemenvén, ott is az minek kellessék lenni kegyelmetekkel egy értelembűl elvégezvén, az relatoriakat ű nagyságának quantotius reportalhassam. Mivel penig mind Lekenczen, s mind Beseniőben múlatásom esik és felesen is leszek ugyan azon oda citalandó szegénység, magun [?] élésünk és lovaink szénája abraka felolll is provideallion az salvus conductus continentiaia szerént" (KvNLt, Beszterce város lt, nr. 11162).

${ }^{630}$ Vö. Trócsányi: Központi kormányzat 230-231.

${ }^{631}$ Szentpáli András nyugtája 1641. július 9-ről. Lásd MOL F25 (Miscellanea II.), f. 248.

${ }^{632} 1650$. január 4-én például Rákóczi György arra utasította a konventet, hogy mivel Kérő birtoka a szamosújvári uradalomhoz tartozik, az inskripciós összeget pedig már elküldte, menjenek ki „a possessorokhoz, úgymint Katonai Ferencnéhez és Istvánnéhoz s ammoneallja, levallják az summat, $\mathrm{s}$ az falut remmittallják fiscusunknak, mellyet ha levalnak az falut foglallja el és applicallja az várhoz, ha nem certificallja őköt intra quindenam producallják hüségtek eleiben igasságokat, alioquin az fiscus hozzá nyolott és az Articulus continentiaia szerént elfoglaltattja simpliciter." Vö. MOL F25 (Miscellanea II.), f. 368. 
nostori uradalom inskripcionális összegét, ${ }^{633}$ egy évvel korábban pedig a Kővár vidéki Hagymáslápos zálogösszegét, 6000 Ft-ot őriztek a requisitorok. ${ }^{634}$ Arra is találtunk példát, hogy a konvent hagyatéki leltár összeállításában és a készpénzvagyon elszállításában segédkezett fejedelmi parancsra. 1648-ban a tanácsúr és ítélőmester, néhai Kassai István kolozsvári házában található értéktárgyak és pénz számbavételét követően került sor a jelentékeny vagyonnak (a fejedelem titkos pecsétjével lezárt zsákocskákba csomagolt 9815 arany Ft-nak) a szamosújvári fejedelmi tárházba való szállítására. ${ }^{635}$ Ennek egyik kollégájuk és egy udvari familiáris általi lebonyolításáról a konvent nyugtát is adott a fejedelemnek. ${ }^{636}$ A Rákócziak idején a konvent és az udvar közötti kapcsolattartás folyamatos lehetett, a fejedelmek, praefectusok levelekben utasították a requisitorokat teendőik elvégzésére és szintén így kérték számon tőlük a jelentéseket. Ezekből a misszilisekből derült ki, hogy a levélkeresők a fiskális uradalmak provisorainak beiktatásában és a jószágok inventálásában is részt vettek. Hogy az új udvarbíró hivatalba állítása és a jószág számbavétele hogyan is ment végbe, Rákóczi György 1641. november 30-án kelt mandatumából derül ki. Ekkor a fejedelem arra utasította a konventet, hogy küldje emberét Szénás Péter fejedelmi praefectus mellé, akitől „,az levelünk meghadatván, az mikor eleikben fogja hüséghteknek adni az tisztben constitualandó udvarbírót, introducallja az tisztben, mindeneket kezében inventalván. Az inventalás penighlen úgy legyen: mindeneket szemével lásson megh, más ember relatiojára semmit, csak egy pénz érőt is fel ne írjon, és az mik megh másálásra, fontolásra és mérésre valók, mindeneket szemek előt igen szorgalmatosan és igazán megh másáltassanak, fontoltassanak és méressenek, lábas marhákat megh számultassanak szemek előt hites bírákkal, polgárokkal. Majorságinkban levő mindenféle asztaginkbann is meny kalongya szám legyen, aszt is az hites bírák s polgárok szavak és relatiojok után, az kik tudniillik azoknak rakatásokban ot forgottanak, írják fel, neveket is megh jegyezvén azoknak az kik relatiojokra azokat felírja. Mely inventalás ez szerént véghben menvén, kezdgyen mindgyárast az jószágh connumeralasához és azt is igen hüséggel és szorgalmatossággal peragalván, hova hamarab nekünk mind az inventalasrúl s connumeratiorúl küldgyön

${ }^{633}$ 1636-ban a konvent oklevelet állított ki arról, hogy eléjük járultak a Mikesek a kolozsmonostori jószág 9000 Ft-ot kitevő inskripciós összegének felvételéért. Mivel nem rendelkeztek megfelelő megbízólevéllel, az összeg átadása elmaradt (KmProt XXX. 15r körül).

${ }^{634}$ 1635-ben Gyulaffi Sámuel és felesége amiatt tiltakoznak, hogy a konventnél őrzött 6000 Ft-os inskripciós összegből hiányzik, habár „ő nagysága felvötte volna, ha it löt volna, és ezután is felveteti, csiak héja ne legyen" (KmProt XXVI. 109²).

${ }^{635}$ Kassai István kolozsvári házában levő ingóságait a requisitorok 1645. április 12-én írták össze. Lásd KápJegyz XIX. p. 59-70.

${ }^{636} \mathrm{KmProt}$ XXXI. 124 
mentűl job dispositioval való inventáriumot és urbariumot kezünkben". ${ }^{637}$ Minden provisor lecserélésekor sor került egy új inventarium elkészítésére, ezek összeállítását és az új udvarbíró beiktatását úgy tünik, többnyire a hiteleshelyek levélkeresőire bízták. Ilyen feladatok elvégzésére a fejedelmi praefectus is utasíthatta a konventet, 1645-ben például Szénás Péter új almási udvarbíró hivatalba állításáról rendelkezett. ${ }^{638}$

Szórványos adataink alapján bizonyosnak tünik, hogy olykor a kamaraispánokat is requisitorok vezették be tisztségükbe. Így történt ez 1645-ben, amikor a dési és aknai javakat vették jegyzékbe, majd azokat az inventatio szerint Alvinci András kezéből az új kamarásnak, Erdős Mihálynak adták át. ${ }^{639}$ Válságos időkben még arra is sor kerülhetett, hogy egy-egy várörség hűségesküjét is a konvent elött tette le. 1657. november 3-án például arra utasították a Gyulafehérváron ülésező rendek a requisitorokat, hogy "halogatás nélkül mindgyárást menjen el és praestáltassa az homagiumot" Rhédei Ferenc nevére a szamosújvári és kővári őrségekkel. ${ }^{640}$

A requisitorok és a fejedelmek közötti levelezés alapján megállapítható, hogy főleg idősebb Rákóczi György követte egy-egy jószág fiskushoz való csatolásának lépéseit, még arról is tájékoztatást kért a requisitoroktól, hogy az általuk őrzött levelek szerint miket lehetne még a kincstár számára requirálni. Pálfi István 1647-ben kelt misszilisében például részletesen beszámolt arról, hogy milyen lépések történtek Szentpáli, Megyeri Ferenc és Csáky urak ügyében, milyen fassiókat vettek be, illetve arról is tájékoztatta fejedelmét, hogy Kászoni József kollégáját elküldte Oroszmező birtok inventálására és connumerálására, a Báthory-jószágokra vonatkozó leve-

\footnotetext{
${ }^{637}$ MOL F25 (Miscellanea II.), f. 259.

${ }^{638}$ 1645. január 18. Szénás Péter praefectus levele Péter deák és Pálfi István requisitorokhoz: „Mivel uram az Almasi tisztartó, Cavassi Nagy Gergely semmi lőt képpen az udvarbíróságnak tisztitt nem akarja peragalni, nem gondolván sem reversalissaval sem penigh az mostani ott lételében való be állattással, hanem magát beteggé tévén vakmerőségre vetette magátt. Én is azért most illyen állapotban vele nem veszekedhetvén, hogy az mi kegyelmes urunk ő nagysága is kárt ne valljon, más udvarbírótt, Kobori Szabo Jánost rendeltem oda, kit innen meg is indítottam, requiralvan azért kegyelmeteket ez levelemmel mingyárast kegyelmetek mennyen el vele Almassra és ott az udvarbíróságnak tisztiben introducalia mind az előbbeni s mind az mostani utólszori inventariumot és urbariumot keziben adván" (MOL F25, Miscellanea II, f. 342); 1648-ban Kászoni József konventi levélkereső a porumbáki udvarbírót introdukálja tisztébe, lásd uo. Arról is szólnak forrásaink, hogy az urbáriumok összeállításához két hiteles ember szükségeltetett, 1641-ben Pécsi (?) János azért rótta meg kollégáját, Pálfi Istvánt, mert az egyedül végezte a gyalui vár inventálását, habár articulus is van arról, hogy "sem captalan, sem más tisztek in solo sua persona semminemő executiot nem tehetnek" (MOL F25, Miscellanea II, f. 261).

${ }^{639} \mathrm{KmProt}$ XXXII. $16^{\mathrm{v}}$ után, számozatlan lapokon.

${ }^{640}$ EOE XI. 325-326. Ekkor a nagyobb hitelesség érdekében és a fejedelmi sigillum hiányában a parancslevelet a gyulafehérvári káptalan pecsétjével erősítették meg!
} 
lek keresésében pedig még nem jártak sikerrel. ${ }^{641}$ Máskor Rákóczi arra utasította szamosújvári udvarbíráját, hogy hívassa magához a konventeket a Macskásiakkal kötendő ügylet írásba foglalása végett, amely szerint azok ajtonyi jussukról a fejedelem számára mondtak le. ${ }^{642}$ Ezek a példák mind arra utalnak, hogy a Rákócziak idejében a konventi levélkeresők a fejedelmi birtokpolitika nélkülözhetetlen és gyakran „,alkalmazott” eszközei voltak. A jószágok elfoglalásához a levéltárban őrzött iratok szolgáltathatták a megfelelö ,jjogalapot", de a requisitorok a végrehajtásban (megintésben, inventálásban, fassiók bevételében stb.) is eljártak. Sőt alkalmanként a hadügyi igazgatásban is szerepet játszottak; hadak mustráját, a székely gyalogok és lovasok összeírását is rájuk bízták. 1634-ben Pécsi János requisitor végezte a Désen, Széken és Udvarhelyen levő mezei hadak szemléjét, ${ }^{643}$ és szintén ő az, aki 1635 végén a hadviselő székelyekről lustrát készített. ${ }^{644}$ Mindezek alapján arra a következtetésre juthattunk, hogy a két Rákóczi uralkodása alatt, de vélhetően már előbb is a hiteleshelyek requisitorai a fejedelmi adminisztráció fontos részei voltak, a fejedelmi birtokpolitika ér-

${ }^{641}$ „Nagyságos uram, az nagyságod kegyelmes parancsolatit külömb külömb üdőkben vevén [?], azokban mit procedaltunk nagyságodnak azálatossan [!] így exhibealom [...]. Az Szentpali András uram Oroszmezeo nevű faluját hogy inventallja és connumerallja József deák collegámat ma elküldötem, csak hogy uram ambigálnak mert Eormezeo felöll vagyon emlékezet inkáb hogy sem Oroszmezeo felől. Ha ez alatt Desy camara ispán uram assignálta (mivel Szentpali uramnak mégh mi hozzánk semmi embere, se levele nem jött) alázatossan értenők ha ugyan Eormezejere az vagy Oroszmezeore kell menny, mert kegyelmes uram mind az két hely igen concurrens, malom is mindenik helyen vagyon [...]. Az Bathori jószágh requiralasában kegyelmes uram semmi processust reá [?] indíthatunk, holott semmi vármegye nincs megírva, melyeket [?] kellessék keresni: az mellyket kezdettük hánni semmit nem találtunk affélét" (KmProt XXXI. 131 $132^{\mathrm{r}}$ ).

${ }^{642}$ 1640. július 24. Rákóczi György levele Szamosújvár provisorához: „Érttyük, hogy az Maczkasiak mindenre reá mentek az derék leveleknek kézben adásán kívül. Azzal is már contentusok leszünk, csak hogy az derék leveleknek mind adgyák pariajátt captalan pecséti alat, s ugyan az Kaptalanban renuncialljanak az Aitoni minden jussoknak, de adigh Colosvarrá nem kel bocsiátani Maczkasi Jánost, hanem ott Uyvarban Maczkassi Péter subscribállja s pecsétellje megh elsőben az levelet s azután Maczkasi Jánost is bocsássa el, s mennyenek Colosvarra, s ott újobban mindketten az Kaptalanban fateallják. De elsőben oda Uyvarban hívassa ki az captalanokat s Czeffey uramot is. Az levél utolljára azt is oda tétesse, ha Maczkassi Péter, vagy az attya megh nem állanák az kötéseket, csak akármi kicsin részbenn is, úgy soha ne perelhessék se kereshessék semmikről Barczai uramat, feleségét és gyermekit és Aytont is mi tölönk" (KmProt XXIX. 135").

${ }^{643}$ "Csak mostan [érkezett] Urunk ő nagysága missilisse, hogy Deesen, Széken és Udvarhelt levő mezei katonákat megh mustrálljuk, holnap jó reggel leszen oda indulásom" (MOL F25. Miscellanea II, f. 33. Pécsi János levele Tordai Péter deákhoz).

${ }^{644}$ MOL F1. 21. 123r-123․ A székely lustrákról bővebben lásd Demény Lajos: XVII. századi történelmünk kiaknázatlan forrásai: a székely katonai összeírások. In: Levéltári Közlemények 66/1995. 53-65. 
vényesítésében és az állam igazgatásában a fejedelem fizetett hivatalnokaiként tevékenyen részt vettek. ${ }^{645}$

\section{3. A konvent kiadványai}

A kolozsmonostori konvent fejedelemség kori kiadványai más hiteleshelyek okleveleivel egyezően privilegiális, pátens vagy zárt alakban keltek. A formai különbségek nagy mértékben az oklevél tartalmával függtek össze; a kiváltságlevél ünnepélyes alakban kiállított és örök érvényưnek szánt, a pátens inkább ideiglenes érvényű, a zárt pedig átmeneti jellegű intézkedést tartalmazott. ${ }^{646} \mathrm{Az}$ oklevelek az ügyfelek kívánságainak és pénzének függvényében díszesebb kiállításúak vagy egyszerübbek voltak.

A konvent fejedelemség kori privilégiumainak anyaga többnyire pergamen ${ }^{647}$ de olykor papír is lehetett. ${ }^{648}$ Tartalmuk szerint nagy részben birtokok iktatásáról kelt jelentések, de privilégiumot adhattak ki bevallásokról (egyezségek, jobbágyfelszabadítások stb.) is. Az ünnepélyes formájú privilégiumokat alkalmanként díszes iniciálékkal ékesítették ${ }^{649}$ ritkán az oklevél egész első sorát arany betűkkel írták és színes díszítéseket alkalmaztak. ${ }^{60}$ Legtöbbször azonban a humanista írással kiállított privilégium első sorát csak scriptura longiorral emelték ki. ${ }^{651}$

A kiállított oklevelek alakja egyre ritkábban volt fekvő téglalap, a hoszszú tanúvallatásokat, iktatásokat egymáshoz ragasztott ívekre írták, utóbb pedig inkább könyv alakú kiadványokat szerkesztettek. Ilyenkor, ha privilégiumot állítottak ki, az összehajtott íveket ugyanazzal a zsinórral fúzték egybe, melyen a pecsét is függött. ${ }^{652}$

${ }^{645}$ A középkorban is elláttak közigazgatási és igazságszolgáltatási feladatokat. Vö. Sipos: Kolozsmonostor 50.

${ }^{646}$ Vö. Kumorovitz: A leleszi konvent 13.; Sipos: Kolozsmonostor 49.; Bilkei: A zalavári és kapornaki konventek 110.

${ }^{647}$ KvNLt, Függőpecsétes oklevelek gyüjteménye, nr. 127. (1577), nr. 27. (1586), nr. 295. (1610).

${ }^{648}$ Uo. egy kiadvány 1579-ből nr. 23. A privilégiumok anyaga tehát nem mindig pergamen, mint ahogyan Papp László megállapította, lásd A hiteles helyek 85.

${ }^{649}$ A gyulafehérvári requisitorok kiadványa 1596. május 4-ről lásd KvNLt, Függőpecsétes oklevelek gyüjteménye, nr. 109.

${ }^{650}$ A kolozsmonostori konvent 1577-ben kelt oklevele uo. nr. 127. Az általa tanulmányozott anyagban Papp László nem talált példát színes díszítésekre, lásd A hiteles helyek 86. További kutatások eldönthetik, hogy az ilyen jellegü díszítés erdélyi jellegzetesség-e. Talán ez is a fejedelmi kancelláriával való szoros kapcsolatra utal.

${ }^{651}$ KvNLt, Függőpecsétes oklevelek gyüjteménye, nr. 295. (1610).

${ }^{652}$ Függőpecsétes könyv alakú oklevelekre csak a gyulafehérvári káptalan kiadványaiból vannak példáink, de kétségtelen, hogy ilyen fajta megoldást a konvent is alkalmazott. Lásd KvNLt, Függőpecsétes oklevelek gyűjteménye, nr. 334. (1597), nr. 338. (1626). 
Az egyes oklevélrészek tekintetében a fejedelemség kora nem sok változást hozott. Ami említést érdemel, és amire már Papp László is felfigyelt, hogy a korszak hiteleshelyi okleveleiben a privilégiumok esetében gyakran szerepel az arenga, amely ekkor már a királyi oklevelekben sem volt használatban. ${ }^{653}$ Ezek formulái részben megegyeznek a szokásos, sablonos szöveggel, de olyanok is vannak, amelyek írójuk gondolatait tükrözik. Ez figyelhető meg például az egyébként is írói hajlamokkal rendelkező mezővárosi származású Pálfi István esetében, aki egy privilégiumként kiadott jobbágyfelszabadítás arengájában a parasztok társadalmi helyzetéről és felemelkedési lehetőségeiről, ${ }^{654}$ Bánffyhunyad kiváltságlevelének átírásakor pedig a hiteleshelyi levéltárak fontos szerepéről értekezett. ${ }^{65}$

A szekularizáció után az oklevelek intitulatiója is megváltozott, a pátensek többnyire „Nos requisitores literarum et literalium instrumentorum in sacristia sive conservatorio Conventus Monasterii Beatae Mariae virginis de Colosmonostra repositarum et locatorum ac quarumlibet judiciariarum deliberationum legitimorumque mandatorum executores" szöveggel kezdenek. ${ }^{656}$ Olykor ez a formula "principalium executores" változatban jelenik meg, ${ }^{657}$ vagy pedig kiegészül a fejedelem vagy kormányzó nevével is. ${ }^{658}$ A privilégiumok esetében az inscriptio és a salutatio gyakran egy mondatba van szorítva a következő formában: „Omnibus Christi fidelibus, praesentibus pariter et futuris notitiam presentium habituris, lecturis vel audituris salutem in omnium salutis largitore", ${ }^{659}$ majd ezt követi a szokott intitulatio.

\footnotetext{
${ }^{653}$ Papp László: A hiteles helyek 83-84. A zalavári és kapornaki kiadványokban viszont Mohács után már nem fordul elő, lásd Bilkei: A zalavári és kapornaki konventek 113.

${ }^{654}$ "Quod quamvis ordinatione divina status humana generis externus ideo ne bona vivendi ratio confunderetur, in diversis gradus sit collocatus et distinctus, ordoque et modus eiusdem bene separatus, moderateque rectus, sic ut superioris gradus personae a mediocribus ac tanto magis ab infimae et plebeae sortis hominibus probe secernerentur, ignobilitasque suam sequeretur conditionem: nihilominus tamen multi plerumque domini heroes magnates et nobiles, qui temporali dominio bonorum et jurium possessionariorum mundanorum necnon servituti rusticanae subjectarum personarum prefuerunt, inventi sunt, qui non paucos bonae indolis juvenes ac virtutibus pollentes plebeae generationis homines, pro heroica sua virtute e conditione ignobili, in qua nati erant eximentes, libertate et immunitate speciali insignerunt condecoraruntque" (KmProt XXXV. 24v).

${ }^{655} \mathrm{KmProt} X X X V .94^{\mathrm{r}}-94^{\mathrm{v}}$.

${ }^{656} \mathrm{KmProt} X V .3^{\mathrm{r}}$.

${ }^{657} \mathrm{KvNLt}$, Kornis lt, fasc. 632, 1650-ben kelt konventi kiadványban.

${ }^{658} \mathrm{KvNLt}$, Kemény lt, fasc. II/112.

${ }^{659} \mathrm{KmProt}$ XXII. 33 ${ }^{\mathrm{r}}$.
} 
A konvent kiadványaiban a fejedelemség korában is az egyházi ünnepek szerint jelölték a keltezést, csak néhány esetben találkoztunk „,mensis” szerinti dátummal. ${ }^{600} \mathrm{Az}$ 1590. december 25-e után kelt okleveleket - az erre vonatkozó országgyülési határozat értelmében - a Gergely-féle naptár szerint keltezték, és erre az újítást követő hónapokban az oklevél szövegében is utaltak („,iuxta stylum novum", ,iuxta novum calendarium"). ${ }^{661}$

A kiadványok nagy része latin nyelvű maradt a fejedelemség korának végéig. $A$ tanúvallomásokat, végrendeleteket, inventáriumokat viszont szinte mindig magyar nyelven foglalták latin keretbe, de ezek mellett a XVII. század elejétől kezdve egyre gyakrabban anyanyelven írott formában vették be a változatos tárgyú fassiókat is. ${ }^{662} \mathrm{Az}$ is előfordult, hogy az először latinul megfogalmazott oklevelet végül - az ügyfél kérésére - magyarul állították ki, erre utal Pálfi István széljegyzete egy 1648-ban kelt latin nyelvü bejegyzés alatt: „Annullatae. Nem annullatae, hanem magyarul kívánták expedialtatni, az mint aláb megteczik" ${ }^{663} \mathrm{Az}$ ügyfelek kérésére a levélkeresők le is fordították a bemutatott latin nyelvű iratot. Így jártak el például 1651-ben, amikor a kolozsvári ötvösök kérésére Báthory Gábor kiváltságlevelét szövegezték meg magyarul, minthogy „plerique essent e numero confratrum cehae predictae Aurifabrorum simpliciores, qui in Latini idiomatis studio minus exercitati, non satis ea, neque eo, quem genuinus earum literarum privilegialium stylus offerret, sensu, intelligere et capescere possent" ${ }^{664} \mathrm{~A}$ felsorakoztatott példák mellett az erdélyi hiteleshelyek kiadványainak nagyobb része azonban teljes szövegében latin nyelven kelt. Ez azt jelenti, hogy annak ellenére, hogy az intézmény egyházi jellege megszűnt, az anyanyelvű írás nem tudta kiszorítani a hagyományos latint. A világiak által múködtetett konvent és káptalan ebben éppen olyan konzervatívnak bizonyult, mint a fejedelmi kancellária. Úgy tünhet, hogy a hitelesség képzetéhez társult a kortársak tudatában a latin nyelv. Ismeretes, hogy a maradandónak szánt okleveleket a fejedelmi kancellárián

\footnotetext{
${ }^{660}$ A vasvári káptalan a XVII. század második felével kezdte a hónap napjai szerint írni a dátumot lásd, Papp: A hiteles helyek 88. Példák a kolozsmonostori konvent okleveleiből: 1576: KmProt VII. 14 ; 1579: KmProt VII. 52r ; A gyulafehérvári levélkeresők is olykor így kelteztek lásd ErdKápJkv VIII/1. 751., 768. sz.

${ }^{661}$ EOE III. 274., 374. Több példát is felsorol a konventi és káptalani kiadványok alapján Fejér Tamás: Fogarasi dokumentumok. Documente Făgărăşene I. (1486-1630). Editate de Antal Lukács. Bucureşti, 2004. (ismertetés az Erdélyi Múzeum LXXI (2009). 1-2. sz.-ban) 93. (a példák a 23. jegyzetben).

${ }^{662}$ Vö. Papp László: A hiteles helyek 90-91.

${ }^{663} \mathrm{KmProt}$ XXXV. f. 24 körül, számozatlan.

${ }^{664}$ Jakab: Oklevéltár II. 221-223. 1643-ban Pécsváradi János kolozsmonostori levélkereső a kolozsvári borbélyok céhlevelét fordította magyarra, lásd uo. 314-320.
} 
is mindig latinul szerkesztették, csak a kisebb jelentőségú mandátumokat, időleges rendelkezéseket szövegezték meg magyarul. ${ }^{65}$

\section{4. A konvent fejedelemség kori pecsétje}

A világi alapon újjászervezett konventi hiteleshelynek valamikor 1575 végén véshettek új pecsétnyomót, amely a fejedelemség korának végéig használatban volt. ${ }^{666}$ A tipárium elkészítésére mindenképpen csak az új szabályokat rögzítő instrukció (1575 ősze) kelte után kerülhetett sor, az azon szereplő évszám pedig ezen év végéig való kivésésre utal. ${ }^{667} \mathrm{~A}$ pecsétnyomó számunkra ismeretlen úton jutott a pannonhalmi bencés apátság gyưjteményébe, ahonnan - hosszas lappangás után - a bencés rend középkori emlékeit bemutató kiállítás előkészítése során került elő. ${ }^{668} \mathrm{~A}$ tipárium ezüstből készült, középrészén gótizáló formákból szerkesztett trónusépítmény látható, rajta Szűz Mária foglal helyet, karján a gyermek Jézussal. Mária fején gyöngyös keresztpánttal összefogott korona van. Takács Imre leírása szerint a vélhetően kolozsvári műhelyben készült vésnöki munka "népies és esetlen”. ${ }^{669} \mathrm{~A}$ kapitális betütípusú körirat szövege: Sig(illum) Con(ventus) Mon(asterii) Bea(tae) Mar(iae) Vir(ginis) de Col(os) Mono(stra) $1575 .{ }^{670}$

\footnotetext{
${ }^{665}$ A fejedelmi kancellária magyar nyelvű okleveleiről lásd Istványi: A magyarnyelvű írásbeliség 82-89.

${ }^{666}$ Ezt a tipáriumot 1700 körül az egyik requisitor elvesztette. Ezért új pecsétnyomót csináltattak, amely kisebb változtatásokkal a korábbi mintáját követte, a köriratban viszont Mono[stra] helyett Mon[ostra] szerepel, az évszám is 1575, de ennek elhelyezése különbözik (ezt a pecsétnyomatot közölte Jerney János: A magyarországi káptalanok és konventek, mint hielmes és hiteles helyek története. In: Magyar Történelmi Tár II. Pesten, 1856. 79. ábra). 1715-ben már az új pecsétnyomót használták (lásd hilibi Gál lt, az EME jelenlegi kézirattárában, fasc. 7, nr. 108). 1721-ben az elveszett tipáriumot megtalálták, és pecsét alatt a főkormányszék levéltárában helyezték el. Az 1575-ös tipárium hányatott sorsát Jakab Elek meglehetősen zavarosan adta elő és magyarázta: Erdély egyháztörténelméhez. 12, 17-18. Világosabban fogalmazott Kastal János konventi conservator Guberniumhoz intézett 1736-os kérelmében, melyben a megkerült pecsét visszaadását kérte, lásd MOL F25 (Miscellanea III.), f. 302-303. A pecsétnyomó visszaszolgáltatására azonban valószínủleg nem került sor, mert Jakab 1867-ben azt még a Gubernium levéltárában látta (innen kerülhetett utóbb a pannonhalmi bencések gyűjteményébe).

${ }^{667}$ Ezzel szemben a gyulafehérvári pecsétnyomó elkészítésére a köriratban szereplő évszám alapján csak 1576-ban kerülhetett sor. Lásd KvNLt, Függőpecsétes oklevelek gyüjteménye, nr. 109.

${ }^{668}$ A pecsétnyomó leírását és képét lásd a Pannonhalmi Főapátsági Gyűjtemények honlapján: http://collections.osb.hu/cgi-bin/targy?targy=578. Vö. Takács: Pecsétnyomó.

${ }^{669}$ Takács: Pecsétnyomó.

${ }^{670}$ A pecsét lenyomatát Kemény József kéziratos gyűjtése is tartalmazza: Erdély pecsétjei I-V. 413. sz. kézirat, egykor az Erdélyi Múzeum-Egyesület Könyvtárában, jelenleg a Román Akadémia Kolozsvári Könyvtárában. II. 82. kép.
} 
A felújított kolozsmonostori pecsétnyomón ábrázolt Madonna-alak megformálása a konvent 1384-ben készült pecsétjéről származtatható. A vésnök nem az előző pecsétnyomót, hanem annak viaszlenyomatát használta, ezért az új pecsét lenyomata a korábbinak éppen tükörképe lett. ${ }^{671}$ Az a tény, hogy az új pecsét megformálásában a régit használták mintaként, egyértelmúen az erdélyi társadalom folytonosság iránti igényét mutatja, a régi intézményi formákhoz és annak külsőségeihez való ragaszkodást jelzi. Nem hisszük, hogy ez az eljárás „,a Mária-kép iránti, még ki nem veszett, ősi vonzódás" következménye, vagy a reformáció képromboló radikalizmusának átmeneti enyhülését jelzi, ${ }^{672}$ csupán arról lehetett szó, hogy az oklevéladó tevékenység minden részletében a megszokott, régi formákat próbálták követni. A régi pecsétképhez való ragaszkodás a gyulafehérvári káptalan esetében is nyomon követhető; ott az 1576-ban készült pecsétnyomó a régi mintájára Szent Mihály arkangyalt ábrázolja ${ }^{673} \mathrm{~A}$ konventi és káptalani pecsétek különleges tekintélyét egyértelmúen jelzi az, hogy válságos időkben, illetve a fejedelmi pecsétnyomó hiányában a rendek azokkal erősítették meg az általuk kibocsátott iratokat. ${ }^{674}$

${ }^{671}$ Takács: Pecsétnyomó. A konvent 1331-1336 között készült tipáriumát István kolozsmonostori jegyző pecséthamisítása miatt semmisítették meg. Leírását lásd Takács Imre: $A$ magyarországi káptalanok és konventek középkori pecsétjei. Múvészettörténeti tanulmány és katalógus a Magyar Tudományos Akadémia Müvészettörténeti Kutató Intézete és a Budapesti Történeti Múzeum másolatgyưjteménye alapján. Bp., 1992. 70.

${ }^{672}$ Takács Imre a pecsét tradicionalista jellegére ezeket a magyarázatokat veti fel.

${ }^{673}$ KvNLt, Függőpecsétes oklevelek gyüjteménye, nr. 263. Az 1576-ban vésett káptalani pecsétnyomó elveszett a XVI. század végi, XVII. század eleji pusztításokban, de az 1609-ben vésett új is a régi mintájára készült, és szintén a régi pecsétképet újították meg az 1658-as pusztításokat követően (vö. DL 74220). Az 1609-es pecsét lenyomatát közölte Kemény József: Erdély pecsétjei II. 80. kép. Az új káptalani pecsétnyomó készítéséről lásd Sunkó: A Gyulafehérvári Káptalan 90-91; KvNLt, Mike Sándor gyüjtemény, nr. 995. A váradi hiteleshely a fejedelmi címert vésette pecsétnyomójára, ennek vélhetően az volt a magyarázata, hogy a világi intézmény nem egy, hanem két egyházi hiteleshely ,jogutódjaként” tevékenykedett.

${ }^{674}$ 1657. november 3-án a rendek Gyulafehérvárról küldik káptalani pecséttel megerősített parancsukat, hogy a várőrségek Rhédei Ferencre esküdjenek fel (EOE XI. 325-326.). 1659. március 26-án a Besztercén egybegyült rendek Magyarországra küldött manifestumukat „publico regni sigillo destituti sub sigillo conventus Colosmonostoriensis” adták ki (EOE XII. 214-216.). 



\section{A KONVENT LEVÉLTÁRA ÉS PROTOCOLLUMAI A FEJEDELEMSÉG KORÁBAN}

A kolozsmonostori konvent hiteleshelyi levéltára az oklevéladó tevékenység megindulásával együtt, már a XIV. században kialakult. Az oklevélkiadó kancelláriáknak és az okleveleket nyerö ügyfeleknek alapvető érdeke volt, hogy a kiadványok nyoma megmaradjon az illető kancelláriánál, és kérésre bizonyíthassa egy-egy oklevele hitelességét, illetve újból kiadhassa azt. Ez a megőrzést és reprodukálást igénylő társadalmi érdek, illetőleg a kialakulóban levő ügyviteli rend vezetett ahhoz, hogy az oklevelek szövege, esetenként tartalmi feljegyzése megmaradjon a kibocsátónál. Ezt a kezdetekben a kibocsátott oklevéllel egyidejüleg készült chirographum útján, majd utóbb a szövegek regisztrumokba való másolásával oldották meg. ${ }^{675}$

A konvent levéltára, akárcsak Leleszen, a hiteleshelyi müködéssel kapcsolatos regisztratúrából és a magánügyfelek által megőrzés végett elhelyezett oklevelekből, illetőleg egyéb iratokból jött létre. ${ }^{676}$ Kolozsmonostoron a középkor folyamán az apátsági templom sekrestyéjében, a többi értéktárgy, illetve a pecsét mellett őrizték a levéltári anyagot is. Az apátság megszüntetése (1556) azonban új korszakot nyitott a konventi levéltár történetében.

Amint a korábbiakban láttuk, az átiratok kiállítására szorítkozó hiteleshelyi tevékenységet ezután a város felügyelete alatt végezték, és a korábbi konventi jegyző, Óvári János deák volt az, aki a levéltári anyag ismerőjeként az átmenetet valamennyire biztosította. A lényegében gazdátlan, de pecséttel lezárt és vélhetően őrzött levéltár azonban egy ideig még korábbi helyén maradt; János deák és kolozsvári polgártársai 1570-ben még Kolozsmonostoron keresték meg az igényelt iratot, melyet magukhoz vettek

\footnotetext{
${ }^{675}$ KmJkv I. 133-134.; Kiss: Más források 172-173.

${ }^{676}$ Kumorovitz: Levéltár 223.
} 
és beszállították Kolozsvárra, ahol az átirat elkészültéig a tanácsházban tartották. ${ }^{677} 1573$-ban is a sekrestyében lehetett a levéltár, ekkor ugyanis a rendek újból szót emeltek a konvent érdekében: „az monostori conventet itíljük károsnak lenni, hogy ez ideig pusztán állott, az levelek is mód és rendtartás nélkűl voltak". ${ }^{678}$

A levéltári anyag Kolozsvárra való áthelyezése végül is csak a hiteleshelyi requisitorok 1575 júniusában való kinevezése után, az ügyviteli utasítások átadásakor valósult meg. ${ }^{679}$ Ekkor az iratanyagot valószínűleg ideiglenesen a tanácsházban helyezhették el. ${ }^{680}$ Ettől kezdve a konventi levéltárnak csak ideiglenes városi őrzőhelye volt, 1655-ben Pálfi István levéltáros a requisitori hivatal negyedik impedimentumaként éppen a "Conservatorium nem lételé" -t sorolta fel. ${ }^{681}$ Ô már pontosan nem tudta, hogy a levéltárat mikor szállították be Kolozsvárra, de megállapította, hogy „,azólta bizonyos Conservatorium nem lévén, ki ki az Conventek közül házánál tartotta az leveleket". Még az is előfordult, hogy az előtte 50 évvel szolgáló levélkereső örökösei adtak be a konventi levéltárhoz tartozó iratokat. 1648-ban éppen a conservatori tisztséget betöltő Pálfi Farkas utcai háza szolgált a konvent „sekrestyéjeként”, amint egy idézőlevélből kiderült. Ebben a furcsa mód maga Pálfi által a fejedelem nevében megfogalmazott oklevélben részletesen leírta az 1648. október 1-jének éjszakáján történt eseményeket: a II. Rákóczi György nevében eljáró és a városban megszálló udvari familiárisok, Sárospataki Czernel Pál és Jenői Vér Ferenc, miután megtudták, hogy Pálfi betegágyban, tehetetlenül fekszik, servitoraikkal együtt felfegyverkezve „noctis in silentio, tempore jam plane ad undecimam horam nocturnam vergente, ad domum ipsius exponentis [Pálfi István háza - B.Zs.], eam videlicet quae pro nunc, exeo quod ea omnia literalia instrumenta, quae alias alibi locata habebantur, in ipsa domo exponentis continerentur, pro sacristia sive conservatorio conventus Colosmonostrensis reputaretur, in platea Luporum intra moenia dictae civitatis regiae Colosvar situatam, ac vicinitatibus domorum ab orientali [...] circumspecti Martini Szindi, ab occidentali vero plagis Stephani Baczi junioris" vonultak, és a requisitort szidalmazva azt lerohanták. ${ }^{682}$ Minthogy a szöveg megszakad, azt nem tudjuk, hogy érte-e kár a támadás során a konventi anyagot, vagy annak Pálfi házában őrzött részét. Úgy tűnik ugyanis, hogy a konventi

\footnotetext{
${ }^{677}$ MOL R 314, Városi iratgyüjtemény, 10. doboz, Vegyes iratok, 2a csomag, f. 25 $5^{r-v}$.

${ }^{678}$ EOE II. 541.

${ }^{679} \mathrm{KmJkv}$ I. 91.; Jakó: Instrucțiunile 91.

${ }^{680}$ Jakab Elek: Erdély egyháztörténelméhez 11. Ebben az időszakban még biztosan nem a Szent Mihály-plébániatemplom tornyában őrizték a levéltárat, mint ahogyan azt Sipos Gábor állította: Kolozsmonostor 36 .

${ }^{681}$ Lásd a 454. sz. jegyzet alatt. Többi adatunkat is hivatkozás nélkül onnan vettük.

${ }^{682}$ MOL F25 (Miscellanea), f. 339r-340r.
} 
levéltárat kétfelé osztották: a kurrens anyagot (protocollumokat, par-példányokat, ügyviteli levelezést stb.) a requisitorok saját házaikban, a konvent régi levéltárát viszont vélhetően bérelt szálláson ơrizték. Éppen Pálfi 1655. évi beadványában említi, hogy a levéltárat folyton hurcolják, „eddig az Cassaiak házánál vol[tak?], továb ők sem szenvedik, hova kell tenni?" Azt nem tudtuk megállapítani, hogy hol is volt Kassai István ítélőmester és családja háza, melynek valamelyik helyiségében a konventi levéltár régebbi anyagait elhelyezték, de forrásaink már 1628-ban is emlegetnek egy "conservatoria domus"-t, melyben egy szerződést kötöttek meg. ${ }^{683}$

A bérelt szállások folyamatos váltogatása, illetve a levéltári anyag "domestice” kezelése, Pálfi István megfogalmazásában „az sok váldozás és hordozás" természetesen károkat okozott a konventi iratokban. Ezért ő a fejedelemnek egy állandó „Conventualis locus” felállítását javasolta, ahol a requisitorok is lakhatnának, e célra pedig a Kolozsmonostoron levő „mángorló ház"-at ${ }^{684}$ javasolta, ahol „mindeneket szép rendbe [...] ládákba helyheztetve [...] háborúságnak idején mind ládástól könyő volna behozni az várasba, mint ennek előtte is". De az sem lenne rossz megoldás, ha Kolozsváron szerezne "az nemes ország” erre a célra egy házat, mert különben jobb lenne a levéltárat a gyulafehérvári káptalan sekrestyéjébe költöztetni. ${ }^{685}$ Erre azonban a konventi levéltár és a történetkutatók szerencséjére - részint az elkövetkező zavaros időszak miatt - nem került sor, hanem minden maradt a régiben. A Pálfi által javasolt változtatások közül csupán annyi valósult meg, hogy folyton Désen időző kollégáját a fejedelem a városba, hivatalához rendelte. ${ }^{686}$

${ }^{683} \mathrm{KmProt} X X V .1^{\mathrm{r}}$. Egyébként már az 1575. évi instrukció is külön conservatoriumot emleget, ahonnan „soha egieb levelet ki ne vidgienek, se szállásokon ne tarczanak, hanem tsak aszt, vagi azokat, kiket valaki requiraltatott es transumaltatni akar véllek, mellyeket post transumptionem ismét mindgiárast helyekre vidgienek". Lásd Jakó: Instrucțiunile 55.

${ }^{684}$ A mángorlóház vászon simítására szolgáló helyiség, lásd SzT VIII. 133. Mikó József halála után, 1636-ban Kolozsmonostor fejedelmi birtok lett (a monostori jezsuiták csupán a templommal rendelkeztek), s a birtokközponthoz tartozó gazdasági épületek között lehetett a mángorlóház is.

${ }^{685}$ A Gyulafehérvárra való átszállítás gondolata már János Zsigmond idejében is felmerült lásd KmJkv I. 90.

${ }^{686}$ Erre II. Rákóczi György 1655. április 9-én kelt leveléből derül fény. A vélhetően Pálfi emlegetett beadványára kelt válaszában a fejedelem nyugtázta, hogy a konventi anyagban a nagy tüzvész nem okozott kárt, de a levéltár elhelyezéséről nem intézkedett: „7. die praesentium nekünk írott hüséged levelét elvőttük, az Conventi levelekben hogy semmi kár nem lőtt, értjük, im parantsoltunk conventbeli társának is, oda mennyen, visellyen gondot az levelekre hüséghtek is. Az mángorló háza felől való írását az mi illeti hüségednek, mivel azt Monostoron vallásunkon levó predikator számára rendeltük szállasul, már nem rendelhettjük másnak, építésből mi segítséggel lehet udvarbiránk, meghláttjuk, tsak hogy nekünk is sok építésünknek kelletik lenni Monostoron" (MOL F25, Miscellanea II, f. 426). 
Az elkövetkező években végül nem a levéltár szervezett költöztetésére, hanem menekítésére került sor, valószínűleg 1658-ban, mikor a tatár pusztítás rászakadt Erdélyre. ${ }^{67}$ Bár az általános fejetlenségben a védekezés megbénult, és nem volt ki intézkedjék, a magukra hagyott levéltárosok utasítások nélkül is megtettek mindent, ami módjukban állott. ${ }^{688} \mathrm{~A}$ menekítést bizonyára a konventi levéltár vezetőjének tekinthető idős, de még mindig tevékeny Pálfi István szervezhette meg. ${ }^{689}$ Ekkor a konventi levéltárat a jól védhető Szamosújvár várába szállították. Az ott elhelyezett iratanyagot talán az ekkor requisitorként tevékenykedő korábbi Doboka vármegyei jegyző, Szamosközi Mihály kezelte, róla tudjuk, hogy 1660-ban a várban jegyzett le a többnyire általa vezetett protocollumba bevallásokat. ${ }^{690}$ A veszély elmúltával, 1664-ben a levéltár újra Kolozsvárra, bérelt szállásra került. Az újonnan kinevezett levélkereső, Szalárdi János történetíró 1664 júniusában már innen keltezte Teleki Mihályhoz intézett levelét: „Asszonyunk ő nagysága parancsolt volt valami levelek keresése felől; attól fogva valóba rajta vagyunk, de, Uram, a conventbéli levelek annyira egyben zavarodtak volt Szamosujvárról az fel s alá való hordozásba, igen sok bajunk van véllek. Mindazáltal, Uram, rajta vagyunk $\mathrm{s}$ ha lészen valahol valami haszonra való ő nagyságának értésére adni s alázatosan meg is küldeni el nem mulatjuk". ${ }^{691}$

Ezután a levéltár sorsáról egy ideig hallgatnak a források, csak 1703 novemberében érdeklődött a Gubernium afelől, hogy a patikáriusné, Jakab deákné vagy pedig Verner Mihályné háza lenne-e alkalmasabb a levelek conservatiójára. ${ }^{692}$ Erre Rákosi Péter és Szentmihályi István requisitorok 1703 decemberében válaszoltak azzal, hogy Jakab patikáriusné házát javasolták kibérelni levéltárnak, és erre mentességet kívántak szerezni a katonai beszállásolások alól, de a háborús események következtében tervük bizonyára nem valósulhatott meg. ${ }^{693}$ 1729-ben, amikor megszüntették a hiteleshelyek világi jellegét, és a konventet az erdélyi káptalan felügyelete alá rendelték, a levéltár még mindig bérelt szálláson, Kolozsvári, másként Jövedécsi István házában volt. ${ }^{694}$ Innen vette át az iratanyagot Lukács András nagyprépost és őrkanonok, és ekkor szállították be a levéltárat a Szent Mihály-plébániatemplom karzatából nyíló boltozott emeleti szobában ki-

\footnotetext{
${ }^{687} \mathrm{KmJkv}$ I. 146.

${ }^{688}$ A gyulafehérvári káptalani levéltár menekítéséről lásd Jakó: Fejedelmi levéltár 112-113.

${ }^{689}$ Gyulafehérváron a káptalani levéltár menekítésére Taraczközi Ferenc „főkáptalan” saját költségére fogadott szekereket. Lásd uo. 112-113.

${ }^{690} \mathrm{KmProt}$ XXXVI. 24, $32^{\mathrm{r}}$.

${ }^{691}$ Teleki Mihály levelezése III. 1664-1666. (szerk. Gergely Sámuel) Bp., 1907. 130-131.

${ }^{692}$ Beke: A kolozsmonostori konvent 544. (645. sz. regeszta).

${ }^{693} \mathrm{KmJkv}$ I. 147.

${ }^{694}$ Jakab Elek: Erdély egyháztörténelméhez 12.
} 
alakított conservatoriumba, majd onnan az 1882. évi törvény értelmében jelenlegi őrzőhelyére, a Magyar Országos Levéltárba.

Miután sort kerítettünk a levéltár szekularizáció utáni „itineráriumának" felvázolására, azt is szükséges bemutatnunk, hogy milyen változások következtek be az iratanyagban, illetve miként történt annak rendezése, és hogy kik vállalkoztak erre a sok fáradsággal járó feladatra. A hiteleshelyi múködés során keletkezett anyag az oklevéladó gyakorlat fejlődési fázisainak megfelelően különböző formát mutat. ${ }^{695}$ A konvent levéltárában fennmaradtak a kibocsátott oklevelek par-példányai, ${ }^{696}$ részleges fogalmazványai, vagy csak a fogalmazványok alapjául szolgáló nótáriusi jegyzetek, signaturák, illetőleg az oklevelek szinte teljes vagy kivonatos szövegeit tartalmazó protocollumok. Ezek mellett azonban a levéltári anyag egyre inkább „országos” jelleget öltött azáltal, hogy a requisitorok feladatai közé sorolták a királyi könyvek, törvénycikkek, adójegyzékek, tizedlajstromok, tizedinstrukciók, hadi mustrák, összeírások és egyéb nagy jelentőségű iratok őrzését is. ${ }^{697} 1638$-ban például a dési complanatio egy példányát küldte a fejedelem a konventi levéltárba, az „jövendő meghmaradásért”. ${ }^{698}$ Máskor úgy vélték megoldottnak egy-egy szöveg megőrzését, hogy azt valamelyik protocollumba másoltatták. ${ }^{699}$ De nemcsak a fejedelmek helyeztek el fontos iratokat a konventnél, hanem ezt - feltehetően megfelelő díj fizetése ellenében - magánosok is megtehették. Leginkább címeresleveleket,

${ }^{695}$ Kumorovitz: Levéltár 223.

${ }^{696}$ 1503-ban az erdélyi vajda arra kényszerítette a konventet, hogy szabálytalan módon megpecsételjenek egy oklevelet, anélkül, hogy azt átírnák, és másodpéldányát a levéltárban helyeznék el. Balázs konventi tag érvelt leginkább amellett, hogy nem szokás olyan oklevelet pecséttel ellátni, melynek párját nem helyezték el a conservatoriumban. Lásd ErdKápJkv VIII/1. 9. (3. jegyzet).

${ }^{697}$ Trócsányi: Kormányhatósági levéltárak 126.; Andrei Kiss: Caracterul specific al locurilor de adeverire din Transilvania în crearea şi păstrarea arhivelor feudale. In: In memoriam Ion Mărcuş. (sub redacția G. Asanache şi L. Mărcuş). Bucureşti, 1979. 65. Nyilvánvalóan nagyobb mennyiségben került ilyen jellegü anyag a fejedelmi székhelyen levő káptalani levéltárba.

${ }^{698}$ „Országunknak Feiervarat celebráltatot az elmúlt tavaszi generalis gyülésében az mint az Unitaria religióban exorialtatot controversiáknak és dissensioknak eligazítása ide, úgymint Dési várasunkban determinaltatot és halasztatot volt, az már végben menvén, és azon religioban való complanatio ecczer s mind azon religiobeli confessioi az arra rendeltetet személyeknek peczétek és kezek írasa alá vettetvén, jövendő meghmaradásért, azt abban az Conventben is reponáltatni akartuk, mellyet ez levelünkkel hűségtek kezéhez dirigalván kegyelmessen parancsolljuk nekiek, reponalják mindgyárast az Conventben, oly helit és gondviselés alat tarcsák, eltévedése ne legyen, sem peniglen akármint is valami akadállya, eső miat vagy penigh valamint való bántódása, maradgyon megh jövendőre is, mindenkorra azon Conventben is" (MOL F25, Miscellanea II, f. 91).

${ }^{699}$ 1617-ben Bethlen Gábor a nagyszombati egyezséget másoltatja be, lásd KmProt XX. 53v$56^{\mathrm{v}}$. 
nemesítéseket és adományleveleket, azaz a családi archívumok legféltettebb darabjait bízták a konventi levélkeresők őrizetére. ${ }^{700}$

\section{1. A levéltárrendezések}

Feltehetően már a levéltár városba való költöztetését követően, 1575 után kísérletet tettek a szállítás és tartós elhanyagoltság miatt összekeveredett anyag valamelyes rendezésére, amint ezt a levélkeresők részére kiállított hivatali utasítás is magában foglalta. ${ }^{701} \mathrm{~A}$ munka nagy részét Szentiványi György requisitor végezhette el. Erre utal az, hogy ő indexeket is készített egy-egy protocollum-kötethez, de a levéltár többi részét, a parpéldányokat és fogalmazványokat is valamennyire rendbe tehette, hiszen ezekről is volt már nyilvántartás. ${ }^{702}$

Az időközben felgyülemlett levéltári anyag és a középkori protocollumok rendezésére a leghosszabb ideig a konventnél szolgáló és annak sorsát szívén viselő requisitor, Pálfi István vállalkozott, feltehetően 1640-1648 között. 1648-ból származik a levéltár általa kialakított rendjéről és kezelési módjáról összeállított utasítása kollégái és hivatalbeli utódjai számára. Ennek megírására az a "rettenetes confusio" is késztethette, melyet egy-egy kollégatársa halála után annak hagyatékából hozzá került levéltári anyagban tapasztalt. ${ }^{703} \mathrm{Az}$ instructióból kiderül, hogy Pálfi a gyakrabban igénybe vett újabb levéltári anyagot (amely feltehetően Farkas utcai házában volt) elválasztotta a ritkábban használt régitől, és - lényegében a mai levéltári rendnek megfelelő - területi és tárgyi csoportokra osztva, ládikákban helyezte el, s az egész anyaghoz hely-, név- és tárgymutatót készített.704 Ugyanakkor köttette be és jelölte az ábécé betüivel, illetve számokkal ${ }^{705} \mathrm{a}$

${ }^{700}$ Egy címereslevél másolata alatt, Pálfi István kezével a következő megjegyzés olvasható: „Nota. Praescriptae literae armales per eundem Georgium Balvanyosvarallyai repositae sunt ad perpetuam conservationem in Conventum nostrum in specie tali tamen conditione, quod si aliquando vel ipse Georgius vel successores eius aliqui rehabere cupiverint eiusdem extradentur, alterius autem partis hominibus non. Steph. Palffy" (KmProt XXXIV. 13r).

${ }^{701} \mathrm{KmJkv}$ I. 144.; Jakó: Instrucțiunile 54.

${ }^{702} \mathrm{KmJkv}$ I. 144-145.

${ }^{703}$ 1646-ban, Tordai Péter deák leveleinek átnézésekor így fakadt ki: „Mikor az szegény Péter deáktól elhozot leveleket hánnám és urunk ő nagysága kegyelmes paranczolattjára requiralnék, és az leveleknek rettenetes confusioia miat semmit nem találnék, jövének hozzám Udvarhelyi György deák uram, urunk cancellarista deákja, másod magával, T. nevűel, kik Basa Mihály statutiojára mennek vala az Mezeoségre. Azért nagy búsultomban solemniter protestalék az leveleknek rút állapattján, hogy oly confuse tartotta" (KmProt XXXI. 84v).

${ }^{704}$ Uo. 145. Az instrukció szövege kiadva Jakó: Instrucțiunile 57-58.; 1647 körül, egy levélkeresésről való jelentés fogalmazványában említik, hogy „,az egész protocolumokat s ládákat kikben az levelek deponaltattak felhántuk" (MOL F25, Miscellanea, f. 322v).

${ }^{705}$ A protocollumok általa írott jegyzékét lásd MOL F25 (Miscellanea), f. 534v. 
régebbi és újabb protocollumokat, részben középkori szertartáskönyvek hártyáját is felhasználva. ${ }^{706}$

A konventhez 1664 áprilisában ${ }^{707}$ requisitornak kinevezett Szalárdi János leveléből ismeretes, hogy a levéltári anyag eléggé megsínylette a Szamosújvárra való menekítést. Ezért, minden nehézség és a korántsem kedvező viszonyok ellenére, Szalárdi rögtön hivatalba kerülése után hozzálátott az összekeveredett iratanyag rendbetételéhez, illetve az elődei által vezetett protocollumok mutatózásához. Töredékes indexének 13 számozott lapja (p. 172-185. közöttiek) a jelenlegi XVIII. protocollum elejéhez kötve maradt fenn. Ez a rész a jelenlegi XXIV., XXV. és XXXIII. jegyzőkönyvek, többnyire Tordai Péter és Kászoni József levélkeresők által vezetett bejegyzései rövid kivonatait tartalmazza, és 1665 . szeptember 29-én készült el. ${ }^{708}$ Minthogy Szalárdi mutatója legalább 185 oldal terjedelmú volt, az egykor vélhetően bekötött index valószínüleg a korábbi protocollum-kötetek nagy részét tartalmazta. Szalárdi azonban nemcsak a konvent könyvbe kötött anyagát rendezte, hanem az okleveleket és a hiteleshelyi tevékenységhez kapcsolódó egyéb iratanyagot is beosztotta, vélhetően a Pálfi-féle rendezés elveit követve. ${ }^{709}$ Ekkor a leveleket valószínűleg zárható és könnyen szállítható ládákban tárolták, ezeken belül az iratokat pedig megszámozták. ${ }^{710}$

A Szalárdi után konventi tisztséget viselő fejedelemség kori levélkeresők már nem vállalkoztak a levéltár rendezésére. Erre valószínűleg sem módjuk, sem különösebb igényük nem lehetett, több vagy kevesebb sikerrel inkább arra törekedhettek, hogy a korábban kialakított rendet a költözések ne zavarják össze. Az elkövetkező időszakban egyébként sem keletkezett olyan nagy mennyiségü lajstromozásra váró iratanyag. A tatárjárást követő tartós és általános válság a konvent müködését is nagymértékben meghatározta. Sokatmondó az, hogy az utolsó fejedelemség kori bejegyzéseket tartalmazó protocollum Szalárdi János 1664-től haláláig írott bejegyzéseivel kezdődik, 127 lap terjedelmü és 1671-es bevallásokkal zárul (ezzel szemben az 1590-1599 közötti bejegyzéseket tartalmazó X. protocollum például 483 fólió terjedelmű). Az elkövetkező kuruc mozgalmak és a sok hányódás során megfogyatkozott és összekeveredett iratok megmentésére

\footnotetext{
${ }^{706}$ Ilyen „,csomagolást” kapott pl. a XVII., XVIII., XXI. és XXVII. jegyzőkönyv.

${ }^{707} \mathrm{KmProt}$ XXXVIII. f. 1.

${ }^{708} \mathrm{Az}$ index 181. oldalán: „In ipso festo S. Michaelis Archangeli die 29. Septembris, anno 1665 Deo auxiliante finitum."

${ }^{709} \mathrm{Az}$ oklevelek hátlapjára írott jegyzetei általában a dátumot és a birtokneveket sorolták fel: MOL F25 (Miscellanea), f. 8v , 29v $, 56^{\mathrm{v}}, 97^{\mathrm{v}}, 107^{\mathrm{r}}$.

${ }^{710}$ Uo. 110 (az oklevél hátlapján: 36, 1. Lada); 169 (az oklevél hátlapján: Ladula 3. Borbely Istwanne 119).
} 
végül csak 1754-től kezdődően történtek intézkedések.711 Ezek bemutatását és értékelését azonban már nem tekintjük feladatunknak.

\section{2. A fejedelemség kori protocollumok}

A kolozsmonostori konvent középkori regisztrumai a középkori Erdély történetének vitathatatlanul leggazdagabb forrásai. ${ }^{712}$ Jakó Zsigmond helytálló megállapítása véleményünk szerint a fejedelemség korára is nagyrészben érvényes; a ránk hagyományozott 28 szekularizáció utáni (1576-1690 között vezetett) protocollum - habár csak részlegesen pótolhatja a nagyrészt elpusztult fejedelmi levéltárat - olyan forrásbázist képez, melynek feltárása és ismerete nélkül Erdély kora újkori története tekintetében továbblépés nem lehetséges, mint ahogy nem lehetséges a káptalani protocollumok és a királyi könyvek feltárása nélkül sem.

A hiteleshely 1575-ben történt újjászervezése után a kinevezett requisitorok a jegyzőkönyvvezetésben is a régi, megszokott módszerekhez tértek vissza. Ekkor viszont már inkább protocollum seu librum a többnyire utólag bekötött jegyzőkönyvek megnevezése. A registrum és a protocollum terminus között tehát valójában nem jelentésbeli, hanem időbeli a különbség, minthogy a XVI. századtól kezdve inkább az utóbbi megnevezés volt használatos. Az 1576-tól fennmaradt négy XVI. századi jegyzőkönyv a szövegmegőrzés tekintetében a legfejlettebb típusba tartozik. ${ }^{713}$ Ezeket valójában másolati könyveknek is nevezhetnénk, hiszen többnyire szinte csonkítatlan szövegú okleveleket tartalmaznak, tehát a protocollumba való bemásolásra a kész tisztázatról a kézbesítés előtt, illetve utólag a teljes szövegü fogalmazványokról kerülhetett sor. ${ }^{714}$ Ezt bizonyítja a bejegyzések gyakran felbomlott időrendje, illetve a kevés számú javítás. Olykor ezeket a fogalmazványokat nem másolták be, hanem egyszerúen protocollumba kötötték. Erre utalnak az ilyen fogalmazványok lapszélein olvasható megjegyzések: „Extradatae et protocolo inscribendae ${ }^{715}$ vagy „Protocolo inscribendae" ${ }^{716} \mathrm{Az}$ utólag érvénytelenített bevallásokat áthúzták, eseten-

\footnotetext{
${ }^{711}$ KmJkv I. 147-149.

${ }^{712}$ A középkori jegyzőkönyvekről bővebben lásd KmJkv I. 133-141. Az erdélyi káptalan középkori iratmegőrzési gyakorlatáról lásd Károly Vekov: Despre evidența documentelor în cadrul locului de adeverire din Alba Iulia. In: Pe urmele trecutului. Profesorului Nicolae Edroiu la 70 de ani (coord. Susana Andea, Ioan-Aurel Pop). Cluj-Napoca, 2009. 103-114.

${ }^{713}$ Vö. KmJkv I. 139-140.

${ }^{714}$ Ezzel szemben Papp László szerint a magyarországi hiteleshelyeken „a XVI. században általában a protocollumban való fogalmazás dívott". Vö. Papp: A hiteles helyek 99-100.

${ }^{715}$ KmProt XVI. 40v.

${ }^{716}$ Uo. $36^{\mathrm{v}}$.
} 
ként pedig széljegyzetben jelölték a visszavonás tényét: „Cassata et annihilata est per eosdem", ${ }^{717}$ "Cassatae sunt presentae litterae". ${ }^{718}$

A kolozsmonostori konventnél a protocollum-vezetés nem eredményezett olyan változatos és bonyolult megoldásokat, mint ahogyan azt Kumorovitz a leleszi konvent kapcsán leírta. Ott a XVI. század elejétől három csoportját különböztették meg a jegyzőkönyveknek: a tulajdonképpeni protocollumokat, a tanúvallatásokról vezetett regisztrumokat és a fassiókról felvett jegyzetek regisztrumait. ${ }^{719}$ A szekularizációt követően úgy tünik, hogy a requisitorok is kísérleteztek az inquisitiókról kelt jelentések külön jegyzőkönyvbe való vezetésével, ${ }^{720}$ de utóbb nem folytatták ezt a gyakorlatot, hanem ezek szövegét is bemásolták a többi bevallás közé. A jegyzőkönyvek nagy része tartalmilag fassionális protocollum, tehát nagyrészben a felek bevallásainak hosszabb-rövidebb szövegeit tartalmazza. Viszonylag ritkán vezették be a külső hiteleshelyi tevékenységről kelt jelentéseket. Ezeket vélhetően inkább úgy őrizték meg, hogy a kézhez vett parancslevelet és azzal együtt a hátlapra írott jelentésfogalmazványt helyezték el a levéltárban. ${ }^{721}$

A protocollum-vezetés módszerei Kolozsmonostoron már a középkor folyamán tökéletesedtek, de tévedés lenne azt gondolni, hogy a fejlettebb gyakorlat megjelenése egyszer és mindenkorra véget vetett a kezdetlegesebb módszereknek. ${ }^{722}$ A szekularizáció előtti változások a requisitorok müködése idején is megfigyelhetők, de irányuk fordított: a fejlettebb megoldások felől tartanak az egyszerübbek és rendetlenebbek felé. Lényegében az 1620-as évek végéig a jegyzőkönyveket másolatkönyveknek lehet tekinteni, tehát ezek töltik be leginkább azt a megőrző szerepet, melyet a protocollumoknak a hiteleshelyi gyakorlatban eredetileg szántak. Ezután, körülbelül a jelenlegi XXII. jegyzőkönyvtől kezdve vegyes megoldásokat alkalmaztak az oklevélszövegek megőrzésében. A legegyszerúbb módszert a felek bevallásával egyidejűleg készített szűkszavú, csak a tárgy lényegét tartalmazó feljegyzések, a signaturák alkotják. Ezekből hiányoznak a szokott formulák, csak valamelyik requisitor által a bevalló vagy képviselője jelenlétében sebtiben papírra vetett jegyzetek. ${ }^{723}$ A signaturák az ok-

\footnotetext{
${ }^{717} \mathrm{KmProt}$ XXXI. $7^{\mathrm{v}}$.

${ }^{718}$ Uo. 9 r.

${ }^{719}$ Kumorovitz: A leleszi konvent 19.

${ }^{720} \mathrm{KmProt}$ VIII. nagy részben attestatiókat tartalmaz. Hasonló félbemaradt kísérlet történt már 1549-1550 körül is, vö. KmJkv I. 141.

${ }^{721}$ Több ilyen maradt fenn a konvent Miscellanea anyagában. Idővel azért is fordulnak elő egyre ritkábban, mert kevésszer végeztettek executiót a konventi requisitorokkal. A konvent középkori jegyzőkönyveiben is ritka a relatio.

${ }^{722} \mathrm{KmJkv}$ I. 136.

${ }^{723}$ Ilyen, gyakran magyar nyelven írott signaturákat tartalmaz, pl. a többnyire Tordai Péter által vezetett XXIII. protocollum.
} 
levéladási folyamat első munkaszakaszát képezték, amint az utólag hozzájuk füzött megjegyzésekből kiderül. ${ }^{724} \mathrm{~A}$ bevalláskor az ügyfél rögtön kifizethette a levélváltság diját, vagy azt későbbre, az oklevél átvételének idejére is halaszthatta. Olykor a bevallás felvétele és az oklevél kiállítása között hosszabb idő is eltelhetett. Nem lehet véletlen, hogy a signaturák megjelenése nagyjából egybeesik azzal az idővel, melytől kezdve a fejedelmi hatalom egyre inkább saját szolgálatába állította a requisitorokat. Ekkortól kezdve történt meg gyakrabban, hogy az oklevelet igénylő ügyfél csak az egyik levélkeresőt találta hivatalában (otthonában), így az - ügyvédvalláson kívül - semmilyen oklevelet ki nem adhatott, hanem az ügyről rövid jegyzetet írt saját jegyzőkönyvébe vagy egy papírszeletre, és ennek alapján requisitor-társai visszatérte után állították ki a tisztázatot.

A requisitor egyenesen a protocollumba is fogalmazhatta az okleveleket, ilyenkor a bevezető formulákat elhagyta, az oklevéladót meg sem nevezte, hanem többnyire a dátummal, nos vagy quod szócskával kezdte, majd rátért az ügyre. A fogalmazványokat onnan könnyủ felismerni, hogy tele vannak sorközi javításokkal, betoldásokkal és emiatt olvasatuk is nehézkes. ${ }^{725} \mathrm{Az}$ elkészült fogalmazványt legalább két requisitor jelenlétében felolvasták, és a becsúszott hibákat ilyenkor javították. ${ }^{726}$ Ilyen szövegeket még a középkori jegyzőkönyvek üresen maradt lapjaira is másoltak. ${ }^{727}$

Az, hogy a signaturákat, fogalmazványokat vagy teljes szövegü bejegyzéseket mekkora részletességgel és figyelmességgel szerkesztették, nagymértékben függött a protocollumot vezető levélkereső képzettségétől, rendszeretetétől és igényességétől. A lelkiismeretesebbek bejegyzéseik élén címszerüen néhány szóban utaltak a szöveg tartalmára, a hanyagabbak ezt gyakran elmulasztották, és ezért utólag mások pótolták ezt a hiányosságot.

A kézírások és más adatok alapján egyértelmüen megállapítható, hogy a hivatalban levő három (vagy olykor két) levélkereső mindenike vezetett jegyzőkönyvet. A requisitor „,saját” protocollumához címlapot készített, ${ }^{728}$

\footnotetext{
${ }^{724}$ "Promisit se solvendo florenum 1." (KmProt XXXI. 16), , Extradata. Uberi stylo" (KmProt XXII. 59v).

${ }^{725}$ Sok ilyen nehezen olvasható fogalmazványt tartalmaz pl. a XXIX. protocollum Pálfi István kezétól.

${ }^{726}$ Egy 1625-ben kelt bejegyzés alatt: „Lecta correcta in voce interlineis per requisitores” (KmProt XXII. 72 $2^{\mathrm{r}}$.

${ }^{727}$ Lásd a DL 36406. kötet 78-87. lapjait, ahol az 1602 táján összeállított helységnévmutató mellett a konvent elött 1601-1602 között tett bevallások fogalmazványait is olvashatjuk.

728 ",Protocolon Conventus Monasterii beatae Mariae Virginis de Colosmonostra. Annorum 1616, 1617, 1618, 1619, 1620, 1621, 1622. Stephano Zeoleosi de Colosvar, requisitore eiusdem conventus inchoatum” (KmProt XX. belső címlap); „Protocollum R. 1656-1661. Domini Valentini Benkeo" (KmProt XXXVI. belső címlap).
} 
a kötetet pedig valószínűleg lakásán őrizte. ${ }^{729}$ Távollétében vagy halála után a bejegyzések vezetését társai folytatták, ezért egy-egy köteten belül több kéz írása is előfordul. ${ }^{730} \mathrm{Ez}$ a jegyzőkönyv-vezetési módszer nagymértékben befolyásolta egy-egy kötet jellegét, hiszen a requisitor hozzáállásán sok minden múlott. A történetíró Szalárdi János még a zűrzavaros, nehéz időkben is törekedett arra, hogy rendezett, áttekinthető és olvasható jegyzőkönyvet hagyjon az utókorra. ${ }^{731}$

Mint korábban említettük, a protocollumi kivonatos bejegyzések nyelve a XVII. század első felétől olykor magyar volt. ${ }^{732} \mathrm{Ez}$ azonban nem azt jelenti, hogy a bevalláskor felvett adatok alapján kiállított oklevél is anyanyelvű lett volna, a tisztázatok között ugyanis még nem találtunk magyarul megfogalmazott oklevelet (arra persze sok példa van, hogy az írásban beadott, magyar nyelvú bevallást latin keretbe foglalták).

A protocollumokban található bejegyzések gyakran felbomlott időrendje arra enged következtetni, hogy az okleveleket nem időrend szerint, hanem számunkra ismeretlen szempontok alapján válogatták és másolták be. Csak gyulafehérvári analógiák alapján, illetve egy káptalani „belső használatra" készült, 1649-1653 közötti időszakban kelt bevallások fogalmazványait tartalmazó ívfüzet segítségével következtethetünk a hiteleshelyi oklevéladás ügyrendjére, a bemásolás feltételeire. ${ }^{733}$ Ebből egyértelmúen kiderült, hogy a káptalan elé járuló ügyfelek bevallásairól az egyik levélkereső időrendi sorrendben rövid signaturákat vett fel, a főkáptalan conservator pedig lapszéli jegyzetekkel utasította kollégáit a szöveg protocollumba való másolására. Az oklevél bemásolását követően a felvett jegyzeteket kihúzták, és a lapszélen az eljárás dijának törlesztésére is utaltak.

${ }^{729}$ Tordai Péter levélkereső 1634 márciusában kelt levelében arra kérte Pécsi János kollégatársát, hogy "ne neheztellye néha néha házamhoz tekinteni interim. Kegyelmedet ezen is kérem, hogy Lazar Istvánné asszonyom newére írjon kegyelmed cum declaratione egy procuratoriat, az új prothocolumban beírtam az dirsset [?], az boltban vagyon az prothocolum, s kegyelmed adgya Pál deák uram kezében, én is mást szolgálok kegyelmednek éretthe." (MOL F25, Miscellanea II. f. 33). A gyulafehérvári levélkereső Bárdi István is szállásán tartotta a protocollumok és a királyi könyvek egy részét, illetve a káptalani pecsétet is. Lásd Sunkó: A Gyulafehérvári Káptalan 93-94. (A regesztában Barkai Ambrus helyett tévesen Barcsai Ákos szerepel!)

${ }^{730}$ Benkő Bálint protocollumában például Szamosközi Mihály és Lutz István keze írása is megtalálható, lásd KmProt XXXVI.

${ }^{731} \mathrm{KmProt}$ XXXVIII. A protocollumok „,herélöit” az egyik levélkereső saját bejegyzése szerint így büntetné: „Nem kár volna ha egyébbel nem büntetni, legaláb kemény plagalassal a tenyerét megplagalni, az ki így herélte s ezután is heréli ki a protocolumokból az tiszta papírossát, nem gondolván azoknak meg vesztegetésekkel, külömben is rút durvájol kimiletlenől bánván vellek, nem gondolván, hogy azok nem csiak mostanra valók volnának, hanem posteritasokra nézve is kellene duralniok" (KmProt XXV. 82v).

${ }^{732}$ Vö. Papp: A hiteles helyek 106.; Bilkei: A zalavári és kapornaki 115.

${ }^{733}$ MOL F2. 52. doboz. 
A hiteleshelyi kiadványok közül tehát csak azokat vezették be a protocollumokba, melyek esetében az oklevelet kérő fél igényelte a regisztrálást, és kifizette az ezért járó díjat.

A konvent oklevéladó tevékenységének hanyatlásával párhuzamosan egyre fokozottabban kerülnek előtérbe a megőrzés szempontjai. Már szekularizáció előtti, XVI. századi adatok is a jegyzőkönyvek megnövekedett bizonyító erejéről vallanak, ${ }^{734}$ a XVII. században pedig egy-egy protocollum királyi könyv jelleget ölt a nagy számban bemásolt nemesítés, címeradomány stb. miatt. ${ }^{735} 1666$-ban már Szalárdi is bizonytalan volt, amikor a gyulafehérvári káptalan egyik 1590-es években vezetett - a zürzavaros időkben magánkézre került - jegyzőkönyvét hozták a konventhez, hogy abból egy bejegyzést átírassanak. A kötetet az alábbi módon írta le: „certum quoddam protocollum seu potius librum regium". ${ }^{736} \mathrm{~A}$ két különböző kancellárián vezetett - egyaránt a megőrzés céljából keletkezett - jegyzőkönyvtípus közötti választóvonal tehát lassan kezdett elmosódni.

A gyakran nehezen olvasható, szemrontó írású protocollumok azóta sem vonzották a kutatókat, hogy az erdélyi hiteleshelyi levéltárakat az 1882-ben hozott törvény értelmében a Magyar Országos Levéltárban helyezték el. A XIX. század végén és a XX. század elején még élt a köztudatban, hogy ezek áttanulmányozása nélkül alapos történeti feldolgozást írni nem lehet, mégis kevesen használták fel a bennük foglaltakat. A szekularizáció után vezetett kötetekben módszeresen egyedül Tagányi Károly kutatott Szolnok-Doboka vármegye monographiájának összeállításakor. A világháborúkat követően a protocollumok szinte teljesen feledésbe merültek. Sokatmondó, hogy Trócsányi Zsolt Erdély központi kormányzati szerveit bemutató alapmüvében sem hasznosította az azokban fellelhető, nem csak archontológiai adatokat.

\footnotetext{
${ }^{734} \mathrm{KmJkv}$ I. 140.

${ }^{735}$ Ilyen jellege van pl. az utólag összeállított XXX. jegyzőkönyvnek, amely nagy számban tartalmazza az Apafi Mihály által kiadott oklevelek másolatait.

${ }^{736}$ DF 257862. Utólag az F15/3. és 4. jelzetű két konventi jegyzőkönyvet is tévesen Izabella királyné királyi könyvének minősítették, lásd KmJkv I. 141.
} 


\section{ÖSSZEGZÉS}

Az erdélyi állam kialakulásával a fennhatósága alá került hiteleshelyek is sajátos útra léptek. A hasonló magyarországi intézményekkel azonos alapokon épülve egy különleges erdélyi intézmény, a requisitori hivatal jött létre, hogy a társadalomnak a jogbiztosító iratok kibocsátása és megőrzése iránti igényét kielégítse. Húszévnyi bizonytalanság után, ami alatt az intézmény tevékenysége a levéltárban őrzött iratok lemásolására és városi pecséttel megerősített átiratokban való kibocsátására szorítkozott, új szervezetet kapott a konventi hiteleshely. A kinevezett requisitorok újra végezhették a hiteleshelyek jogkörébe tartozó tevékenységeket, de részben kis létszámuk, részben egyéb iratkibocsátók (vajdai vagy fejedelmi emberek, vármegyék) működése miatt lassanként kiszorultak az executiós tevékenységből. Ebben a folyamatban korszakhatárt vélhetően az Approbaták jelentettek. Az 1650-es évek második felétől kezdődően a külső hiteleshelyi tevékenység valószínűleg megszűnt. Ugyanakkor az 1658-as esztendőben bekövetkezett katasztrófa, majd az azt követő tartós bizonytalanság a hiteleshely müködésében is akkora törést okozott, hogy lényegében eddig is számíthatnánk a konvent fejedelemség kori történetét. A továbbiakban az oklevéladás inkább alkalmi jelleget öltött, már nem az iratkibocsátás, hanem a megőrzés szempontjai kerültek előtérbe. Azt is mondhatnánk, hogy ekkortájt ér véget a hiteleshelyi intézmény története, és kezdődik igazán a levéltáré. A levéltáré, amely a fejedelemség korában a rendek és a fejedelmek intézkedései következtében a gyulafehérvári káptalani és vélhetően a váradi hiteleshelyi archívum mellett Erdély egyik országos iratvédelmi intézménye lett.

Mindezek bekövetkezte elött azonban a konvent a fejedelmi kancellária és az ehhez szorosan kapcsolódó gyulafehérvári káptalani hiteleshely, illetve a váradi requisitorok mellett Erdély egyik legjelentősebb oklevél- 
kibocsátója volt. Mindhármójuk működését nagymértékben befolyásolta tevékenységük helyszíne. A konvent Kolozsvárra költöztetésével például a korábban jellegzetesen nemesi intézmény „városias” jelleget is öltött. Maguk a levélkeresők is jelentős tisztségeket viselő városi polgárok voltak vagy lettek, és a városlakók hiteleshely iránti bizalma is megnövekedett. A Tripartitum tiltása ellenére egyre gyakrabban intézték kolozsvári városi ingatlanaikra vonatkozó ügyeiket is a requisitorokkal. Az új helyszín, illetve a társadalmi változások komolyan befolyásolták az oklevéladó tevékenységet, meghatározták a kiállított oklevelek típusait és a konvent forgalmát is. A konventi levéltár városba költöztetése a bevallások felvételének menetét is nagymértékben meghatározta. A levélkeresők ugyanis az iratanyag egy részét saját szállásaikon őrizték, és házaiknál került sor az ügyfelek által előadottak írásba foglalására is, habár arra is találtunk példát, hogy ez egy "conservatoria domus"-nak nevezett helyen történt. A hiteleshelyi tevékenységben fennakadásokat okozott az, hogy a Rákócziak fejedelemsége alatt a levélkeresőkre egyre gyakrabban bíztak olyan birtok- vagy államigazgatási feladatokat, melyek korábban nem tartoztak a hiteleshelyek tevékenységi körébe. A requisitorok tehát a fejedelem fizetett hivatalnokaiként az ország adminisztrálásában is részt vettek.

A konvent és a vármegye közötti kapcsolat középkori előzmények alapján a fejedelemség korában is tovább élt azáltal, hogy valamelyik levélkereső gyakran a vármegye jegyzői vagy adószedői hivatalát is viselte. A vármegyei és a hiteleshelyi írásbeliség ilyen módon való összefonódására részben az adott okot, hogy a hiteleshely és a sedria ugyanabban a városban székelt, részben pedig valószínủleg az, hogy a hiteleshelyi requisitorok alapos jogi felkészültséggel rendelkező hivatalnokokként egyébként is állandó kapcsolatban voltak a vármegyei nemességgel, ismerték az éppen folyamatban levő peres ügyeket, hiszen ők foglalták írásba az azokhoz kapcsolódó iratanyag jelentős részét.

Az oklevéladó tevékenység minőségét természetesen nagymértékben az is meghatározta, hogy a levélkeresők miként viszonyultak hivatalukhoz, mennyire voltak képzettek, és milyen lelkiismeretesen végezték munkájukat. Úgy véljük, hogy a közölt életrajzi vázlatok, illetőleg a fennmaradt levéltári anyag tekintélyes mennyisége egyaránt azt bizonyítják, hogy feladataik végzésében a múlt emlékei iránti érdeklődés és a felelősségtudat is komoly szerepet játszott.

A konvent fejedelemség kori müködését áttekintve felmerül az a kérdés, hogy mennyiben tekinthetjük még hiteleshelynek ezt a fejedelmi hatalom alá rendelt, világiak által müködtetett intézményt. A középkori 
hiteleshelyek meghatározása szerint ${ }^{737}$ bizonyosan nem illik ebbe a kategóriába a requisitorok oklevéladó hivatala, minthogy nem volt egyházi intézmény. A felvázoltakból viszont az is kiderült, hogy a levélkeresők is testületként, igaz, világi testületként müködtek, részben a fejedelem, részben az évszázados hagyományokkal rendelkező egykori egyházi intézmény tekintélyére alapozva. Éppen úgy, mint korábban, ügyfeleik megkeresésére vagy fejedelmi megbízásra okleveleket állítottak ki, és e tevékenységükben - kisebb változtatásokkal - megőrizték a régi, szokott mintákat. Habár, mint láttuk, a fejedelmek olyan feladatokat is a levélkeresőkre bíztak, melyek korábban nem tartoztak a hiteleshelyek feladatkörébe, illetve a levéltáruk is „országos” jelleget öltött, alaptevékenységük mégis, mint korábban, a bevallások felvétele és a hiteleshelyi levéltár ôrzése maradt. Ez egyértelműen megkülönbözteti a konventet azoktól az intézményektől (vármegye, fejedelmi kancellária stb.), melyek hiteleshelyi jellegú tevékenységet is folytattak, illetve az executiók végrehajtásában fokozatosan átvették a konvent és a káptalanok helyét, és inkább a magyarországi, egyházak keretében működő hiteleshelyekkel rokonítja. A királyi Magyarország területén tevékenykedő egyházi hiteleshelyek, illetve a világiak által müködtetett erdélyi hiteleshelyek okleveleinek középkori mintákat követő formulái is - kivéve természetesen az intitulatiót - lényegében azonosak.

Végül, ha a kolozsmonostori konvent fejedelemség kori hiteleshelyi tevékenységének mérlegét kívánjuk megvonni, a Papp László által a törvényi rendelkezések és korábbi szegényes irodalom alapján ábrázoltakat, illetve a Pálfi István 1655-ben kelt beadványában felsorolt impedimentumokat kell összevetnünk az oklevéladó tevékenység termékeivel, a protocollumokkal és a kiadványokkal. A fennmaradt fejedelemség kori levéltári anyag mennyisége és minősége egyaránt azt bizonyítja, hogy a megváltozott világ igényeinek megfelelően átalakított kolozsmonostori konvent még hosszú ideig a fejedelmi Erdély egyik jelentős iratkibocsátója és megőrzője maradt.

${ }^{737}$ Korai magyar történeti lexikon (9-14. század). Főszerk. Kristó Gyula. Szerk. Engel Pál és Makk Ferenc. Bp., 1994. 263-264. 



\section{RÖVIDÍTÉS- ÉS IRODALOMJEGYZÉK}

\section{Levéltári és kézirattári források}

Bánffy lt = A gr. Bánffy család nemzetségi levéltára a ENMLt-nak a KvNLtban ôrzött anyagában

Batthyaneum. A gyulafehérvári káptalan és a kolozsmonostori konvent levéltárai

Beszterce város levéltára a KvNLt-ban

A Középkori Magyarország Levéltári Forrásainak Internetes Adatbázisa (DL-DF): http://mol.arcanum.hu/dldf/opt/a101129htm?v=pdf\&a=start

EME Kézirattára, a Kolozsvári Egyetemi Könyvtár (BCU) őrizetében, MS 309 (Formularium)

ENMLt $=$ Erdélyi Nemzeti Múzeum Levéltára (a KvNLt őrizetében)

Függőpecsétes oklevelek gyűjteménye (Documente cu peceți atârnate) a KvNLt-ban

hilibi Gál lt, az EME jelenlegi kézirattárában

KápJegyz = Magyar Országos Levéltár. Erdélyi Kormányhatósági Levéltárak. A Gyulafehérvári Káptalan Országos Levéltára. Protocollumok (F2)

Kemény József: Erdély pecsétjei I-V. 413. sz. kézirat, egykor az Erdélyi Múzeum-Egyesület Könyvtárában, jelenleg a Román Akadémia Kolozsvári Könyvtárában

Kemény lt = A br. Kemény család csombordi levéltára a KvNLt-ban 
KmProt = Magyar Országos Levéltár. Erdélyi Országos Kormányhatósági Levéltárak. A Kolozsmonostori Konvent Országos Levéltára. Protocollumok (F15)

KolJkv = Kolozs vármegye jegyzőkönyvei az ENMLt-nak a KvNLt-ban őrzött anyagában

Kolozsvár város lt a KvNLt-ban

Kolozsvár város számadáskönyvei (KvSzám) a KvNLt-ban

Kolozsvár város tanácsi jegyzőkönyve (1666-1696) az Egyetemi Könyvtár Kézirattárának őrizetében (BCU. Ms 990)

Kolozsvári Református Egyházközség lt (az Erdélyi Református Egyházkerület lt-ban)

Kolozsvári Unitárius Egyházközség Levéltára, Egyházfiak számadásai II.

Kornis lt, az ENMLt-nak a KvNLt-ban őrzött anyagában

KvNLt $=$ Román Nemzeti Levéltár Kolozs Megyei Igazgatósága

Mike Sándor gyűjtemény az ENMLt-nak a KvNLt-ban ôrzött anyagában

MOL F1 = Magyar Országos Levéltár. Erdélyi Fejedelmi Kancellária, Libri regii

MOL F25 (Miscellanea) = Magyar Országos Levéltár. A Kolozsmonostori Konvent Levéltára, Miscellanea

MOL R 314 = Magyar Országos Levéltár. Városi iratgyüjtemény, 10. doboz, Vegyes iratok

Wesselényi $1 \mathrm{t}=\mathrm{A}$ br. Wesselényi család zsibói levéltára az ENMLt-nak a KvNLt-ban őrzött anyagában

\section{Irodalomjegyzék}

A Magyarországi Középkori Latinság Szótára III. Budapest, 1992.

A Wass család cegei levéltára. Valentiny Antal oklevélkivonatait felhasználva bevezető tanulmányokkal és jegyzetekkel közzéteszi W. Kovács András. Kolozsvár, 2006.

A zalavári és kapornaki konventek hiteleshelyi levéltárainak oklevélregesztái 1542-1544 (szerk. Bilkei Irén). Zalaegerszeg, 2002.

AC = Approbatae Constitutiones. In: 1540-1848. évi erdélyi törvények (Ford. és utalásokkal ellátták Kolosvári Sándor és Óvári Kelemen). Budapest, 1900.

B. Nagy Margit: Várak, kastélyok, udvarházak ahogy a régiek látták. XVII-XVIII. századi erdélyi összeírások és leltárak. Bukarest, 1973. 
Balogh Jolán: Kolozsvári kőfaragó múhelyek. XVI. század. Budapest, 1985.

Balogh Jolán: Varadinum. Várad vára I. Budapest, 1982.

Basta György hadvezér levelezése és iratai II. (1602-1607). A Magyar Tud. Akadémia Történelmi Bizottsága megbízásából hazai és külföldi levéltárakban gyüjtötte és közrebocsátja Veress Endre. Budapest, 1913.

Beke: A kolozsmonostori konvent $=A$ kolozsmonostori konvent levéltára. Ismerteti Beke Antal. Kny a Történelmi Tár 1896-1898. évfolyamaiból.

Békés vármegye hajdana. Írta Haan Lajos. II. kötet. Oklevéltári rész. Pest, 1870.

Berger Albert-Wagner Ernst: Urkundenregesten aus dem Archiv der Stadt Bistritz in Siebenbürgen II. Köln-Wien 1986.

Bethlen Farkas: Erdély története III. Budapest-Kolozsvár, 2004.

Bilkei: A zalavári és kapornaki konventek = Bilkei Irén: A zalavári és a kapornaki bencés konventek hiteleshelyi tevékenysége a Mohács utáni évtizedekben. In: Loca credibilia. Hiteleshelyek a középkori Magyarországon (szerk. Fedeles Tamás-Bilkei Irén). Pécs, 2009. 87-130.

Binder 1982 = Binder Pál: Közös múltunk. Bukarest, 1982.

Bíró Vencel: Bethlen Gábor és az erdélyi katolicizmus. In: Ódon Erdély. Budapest, 2004. (elektronikus változata: http://mek.oszk.hu/04900/04920/ index.phtml)

Bogdándi Zsolt: A kolozsmonostori konvent fejedelemség kori levélkeresői. In: Erdélyi Múzeum LXXII (2010). 3-4. füzet, 43-72.

Bogdándi Zsolt: Az erdélyi hiteles helyek müködése a szekularizációt követően. In: 700 éves a közjegyzőség Magyarországon (szerk. Rokolya Gábor). Budapest, 2008. 41-53.

Bogdándi Zsolt: Tanúvallatások a XVI. század második feléból. Az erdélyi hiteleshelyi jegyzókönyvek forrásértékéról. In: Történeti tanulmányok XII. A Debreceni Egyetem Történeti Intézetének kiadványa (szerk. Takács Péter). Debrecen, 2004. 25-31.

Bogdándi: A váradi hiteleshely $=$ Bogdándi Zsolt: $A$ váradi hiteleshely a szekularizációt követóen. In: Erdélyi Múzeum LXXIII (2011). 3-4. füzet, 104-116.

Bogdándi: Balásfiak = Bogdándi Zsolt: A kolozsvári Balásfiak. In: Református Szemle 96. évf. (2003. november-december). 807-812.

Bónis: A jogtudó értelmiség = Bónis György: A jogtudó értelmiség a Mohács előtti Magyarországon. Budapest, 1971. 
Borsa Iván: A hiteleshelyekról. In: „Magyaroknak eleiről”. Ünnepi tanulmányok a hatvan esztendős Makk Ferenc tiszteletére (szerk. Piti Ferenc). Szeged, 2000. 99-106.

Borsa Iván: A királyi ember és a hiteleshelyi küldött melléktevékenysége Leleszen. In: Emlékkönyv Jakó Zsigmond születésének nyolcvanadik évfordulójára. Kolozsvár, 1996. 101-108.

Bunyitay = Bunyitay Vince: $A$ váradi püspökség története I-III. Nagyvárad, 1883-1884, IV. Debrecen, 1935.

C. Feneşan-K.G. Gündisch: Informații privind istoria Transilvaniei (sec. XVIXVII) în calendarele lui Paul Eber. In: Anuarul Institutului de Istorie Cluj XVII/1974. 79-97.

C. Tóth Norbert: Adatok a megyék és a hiteleshelyek közötti viszonyra a 14. és 15. században. In: Századok 136 (2002). 351-364.

C. Tóth Norbert: Szabolcs megye = C. Tóth Norbert: Szabolcs megye múködése a Zsigmond-korban. Nyíregyháza, 2008.

CDTrans $=$ Codex diplomaticus Transsylvaniae. Diplomata, epistolae et alia instrumenta litteraria res Transsylvanas illustrantia. Erdélyi Okmánytár. Oklevelek, levelek és más írásos emlékek Erdély történetéhez I. (1023-1300). Bevezető tanulmánnyal és jegyzetekkel regesztákban közzéteszi Jakó Zsigmond. Budapest, 1997. - II. (1301-1339). Regesztákban jegyzetekkel közzéteszi Jakó Zsigmond. Budapest, 2004.

Compilatae Constitutiones. In: 1540-1848. évi erdélyi törvények (Ford. és utalásokkal ellátták Kolosvári Sándor és Óvári Kelemen). Budapest, 1900.

Csapodi Csaba: Szabadosok (libertini) 1514-1848. In: Századok LXXIV (1940). 405-426.

Czimerlevelek. Gyüjtötte Sándor Imre. II. füzet, Kolozsvár, 1910.

Dáné Veronka: „Az ônagysága széki így deliberála”. Torda vármegye fejedelemségkori bírósági gyakorlata. Erdélyi Tudományos Füzetek 259. DebrecenKolozsvár, 2006.

Decreta Regni Hungariae. Gesetze und Verordnungen Ungarns 1301-1457. Collectionem manuscriptam Francisci Döry. Additamentis auxerunt, commentariis notisque illustraverunt Georgius Bónis, Vera Bácskai. Budapest, 1976.

Demény Lajos: XVII. századi történelmünk kiaknázatlan forrásai: a székely katonai összeírások. In: Levéltári Közlemények 66/(1995). 53-65. 
Dominkovits Péter: Vármegyei vezetók, közigazgatási feladatok a 17. századi Sopron és Vas vármegyék példáján. In: Megyetörténet. Egyház- és igazgatástörténeti tanulmányok a veszprémi püspökség 1009. évi adománylevele tiszteletére (szerk. Hermann István és Karlinszky Balázs). Veszprém, 2010. 421-444.

Dósa: Jogtudomány = Dósa Elek: Erdélyhoni jogtudomány. Kolozsvártt, 1861.

Dreska Gábor: A pannonhalmi konvent hiteleshelyének 14. századi oklevélátírásai. In: Mons Sacer I. Pannonhalma, 1996. 463-470.

Dreska Gábor: A pannonhalmi konvent hiteleshelyének müködése a Zsigmondkorban. In: Levéltári Közlemények 68 (1997). 1-2. sz. 3-61.

Dreska Gábor: Egyházi intézményeink közhitelü iratkiadásának középkori emlékei. In: 700 éves a közjegyzőség Magyarországon (szerk. dr. Rokolya Gábor). Budapest, 2008. 26-40.

Dreska: A pannonhalmi konvent = Dreska Gábor: $A$ pannonhalmi konvent hiteleshelyi tevékenysége 1321-1500. Doktori disszertáció elektronikus változata (http://doktori.btk.elte.hu/hist/dreska/diss.pdf)

Eckhart Ferenc: Die glaubwürdigen Orte Ungarns im Mittelalter. In: Mitteilungen des Instituts für österreichische Geschichtsforschung, 1914. 395-558.

Ember Győző: Az újkori magyar közigazgatás története Mohácstól a török kiüzéséig. Budapest, 1946. 486-494.

Emődi Tamás: A szilágycsehi református templom. Erdélyi müemlékek 21 (1996).

Entz Géza: A gyulafehérvári székesegyház. Budapest, 1958.

$\mathrm{EOE}=$ Erdélyi országgyülési emlékek (Monumenta comitialia regni Transsylvaniae. Szerk. Szilágyi Sándor). I-XXI. Budapest, 1876-1898.

Erdélyi Könyvesházak II. Kolozsvár, Marosvásárhely, Nagyenyed, Szászváros, Székelyudvarhely. Szeged, 1991. (Adattár 16/2)

Erdélyi könyvesházak III. (Sajtó alá rendezte Monok István, Németh Noémi, Varga András). Adattár 16/3. Szeged, 1994.

Erdélyi Pál: A Teleki-énekeskönyv. Második közlemény. In: Erdélyi Múzeum XXIV (1907). 360-372.

Erdélyország történetei tára. Egykoru s magyar nyelven készittett történet-iratok-, levelek-, országgyülési végzések- és törvényczikkelyekből. Kiadják gróf Kemény József és Nagy Ajtai Kovács István. Első kötet 1540-1600. Kolozsvártt, 1837. 
Erdélyország történetei tára, egykorú s magyar nyelven készített történetiratok-, levelek, országgyủlési végzések- és törvényczikkelyekből II. 1845 (közzéteszi Kemény József és nagyajtai Kovács István).

ErdKápJkv $=A z$ erdélyi káptalan jegyzókönyvei 1222-1599. (Erdélyi Történelmi Adatok VIII. 1. Szerk. Jakó Zsigmond). Mutatókkal és jegyzetekkel regesztákban közzéteszi Bogdándi Zsolt - Gálfi Emőke. Kolozsvár, 2006.

ErdKirKv = Az erdélyi fejedelmek Királyi Könyvei I. 1569-1602. (Erdélyi Történelmi Adatok VII. 1-3. Szerk. Jakó Zsigmond). VII. 1. János Zsigmond Királyi Könyve (1569-1570). VII. 2. Báthory Kristóf Királyi Könyve (1580-1581). VII. 3. Báthory Zsigmond Királyi Könyvei (1582-1602). Mutatókkal és jegyzetekkel regesztákban közzéteszi Fejér Tamás, Rácz Etelka, Szász Anikó. Kolozsvár, 2003-2005.

Fasciculus rerum $=$ Fasciculus rerum scholasticarum collegii Claudiopolitani unitariorum I. Journals of the years 1626-1696. Prepared and arranged by Edit Dományházi, Miklós Latzkovits. Szeged, 1997.

Fedeles Tamás: A pécsi székeskáptalan személyi összetétele a késő középkorban (1354-1526). Pécs, 2005.

Fejér Tamás: Fogarasi dokumentumok. Documente Făgărăşene I. (1486-1630). Editate de Antal Lukács. Bucureşti, 2004 (ismertetés az Erdélyi Múzeum LXXI (2009). 1-2. sz.-ban).

Fekete Lajos: A vármegyei tisztikar a XVI-XVII. században. Budapest, 1914.

Gál: Unitárius kollégium = Gál Kelemen: $A$ kolozsvári unitárius kollégium története (1568-1900). II. H.n. 1935.

Gálfi Emőke: Az aradi káptalan regisztrumtöredéke és regisztrumának előszava. In: Erdélyi Múzeum LXXII (2010). 3-4. füzet. 185-196.

Gáll Erwin-Gergely Balázs: Kolozsvár születése. Régészeti adatok a város 10-13. századi történetéhez. Kolozsvár, 2009. 106-107.

Herepei János: A dési református iskola XVII. és XVIII. századbeli igazgatói és tanítói. Erdélyi Tudományos Füzetek 130. sz, Kolozsvár, 1941.

Herepei: Házsongárd = Herepei János: $A$ házsongárdi temetô régi sírkövei. Budapest, 1988.

Herepei: Adattár = Herepei János: Adattár a XVII. századi szellemi mozgalmaink történetéhez. I-III. Budapest-Szeged, 1965-1971.

Horn Ildikó: Hit és hatalom. Az erdélyi unitárius nemesség 16. századi története. Budapest, 2009.

Horn Ildikó: Tündérország útvesztői. Tanulmányok Erdély történelméhez. Budapest, 2005. 
Istványi: A magyarnyelvü írásbeliség = A magyarnyelvú írásbeliség kialakulása. Budapest, 1934.

Jacobinus János erdélyi kancellár formuláskönyve (1602). Bevezetéssel és jegyzetekkel közzéteszi Bónis György és Valentiny Antal. Jogtörténeti és népi jogi tanulmányok 2. Kolozsvár, 1947.

Jakab Réka: A veszprémi káptalan újkori hiteleshelyi tevékenysége az első felvallási jegyzőkönyv alapján (1635-1653). In: Levéltári Szemle 2008/3. 82-90.

Jakab: Erdély egyháztörténelméhez = Jakab Elek: Erdély egyháztörténelméhez. Történelmi Tár 13/1867.

Jakab: Oklevéltár II. = Jakab Elek: Oklevéltár Kolozsvár története második és harmadik kötetéhez. II. kötet. Budapesten, 1888.

Jakó Klára: Betűművész = Jakó Klára: Egy XVII. századi betûmüvész könyvtára. In: Müvelődés 37/1984. 2. sz. 37-38.

Jakó Klára: Az első kolozsvári egyetemi könyvtár története és állományának rekonstrukciója 1579-1604. Erdélyi Könyvesházak I. Szeged, 1991.

Jakó Klára: Lekcsei Sulyok Imre kancellárról. In: Emlékkönyv Kiss András születésének nyolcvanadik évfordulójára. Kolozsvár, 2003. 191-207.

Jakó Zsigmond: Az erdélyi vajda kancelláriájának szervezete a XVI. század elején. In: Erdélyi Múzeum LII (1947). 50-80.

Jakó Zsigmond: Csáki Mihály (1492-1572) erdélyi kancellár származásáról. In: Társadalom, egyház, múvelődés. Tanulmányok Erdély történelméhez. Budapest, 1997. 91-96.

Jakó Zsigmond: Rődi Cseh István, az anyanyelvü írásbeliség egyik erdélyi úttörője. In: Írás, könyv, értelmiség. Tanulmányok Erdély történelméhez. Bukarest, 1976. 37-41.

Jakó: Dézsma = Jakó Zsigmond: Adatok a dézsma fejedelemségkori adminisztrációjához. Erdélyi Történelmi Adatok V. 2. Kolozsvár, Erdélyi Múzeum-Egyesület, 1945.

Jakó: Fejedelmi levéltár = Jakó Zsigmond: Az erdélyi fejedelmek levéltáráról. In: Tanulmányok Borsa Iván tiszteletére (szerk. Csukovits Enikő). Budapest, 1998. 109-111.

Jakó: Gyalu = Jakó Zsigmond: $A$ gyalui vártartomány urbáriumai. Kolozsvár, 1944.

Jakó: Instrucțiunile = Jakó, Sigismund: Instrucțiunile arhivistice ale oficiilor din Transilvania, 1575-1841. Problema reorganizării arhivelor vechi din Transilvania. In: Revista Arhivelor I (1958), nr. 1. 54-56. 
Jakó: Vajdai kancellária = Jakó Zsigmond: Az erdélyi vajdai kancellária szervezete a XVI. század elején. In: Írás, könyv, értelmiség. Tanulmányok Erdély történelméhez. Bukarest, 1977. 42-61.

Janits Iván: Az erdélyi vajdák igazságszolgáltató és oklevéladó müködése 1526-ig. Budapest, 1940.

Jerney János: A magyarországi káptalanok és konventek, mint hielmes és hiteles helyek története. In: Magyar Történelmi Tár II. Pesten, 1856.

Jezsuita Okmánytár I/1. Erdélyt és Magyarországot érintő iratok 1601-1606. Sajtó alá rendezte Balázs Mihály, Kruppa Tamás, Lázár István Dávid, Lukács László. Szeged, 1995.

Kádár József - Tagányi Károly - Réthy László - Pokoly József: Szolnok-Doboka vármegye monographiája I. Deés, 1901.

Kemény: Notitia = Kemény Josepho: Notitia historico-diplomatica archivi et literalium Capituli Albensis Transsilvaniae. I-II. Cibinii, 1836.

Kénosi Tőzsér János - Uzoni Fosztó István: Az erdélyi unitárius egyház története I. Fordította Márkos Albert. A bevezető tanulmányt írta és a fordítást a latin eredetivel egybevetette Balázs Mihály. Kolozsvár, 2005.

Kertész Balázs: Az Országos Széchényi Könyvtár MNY 64. jelzetü nyelvemlékérôl. (Egy hiteleshelyi eljárás során készitett feljegyzés). In: Levéltári Közlemények LXXVII (2006). 1. sz. 91-103.

Kiss, Andrei: Caracterul specific al locurilor de adeverire din Transilvania în crearea şi păstrarea arhivelor feudale. In: In memoriam Ion Mărcuş (sub redacția G. Asanache şi L. Mărcuş). Bucureşti, 1979. 62-71.

Kiss: Források $=$ Kiss András: Források és értelmezések. Kriterion Könyvkiadó, Bukarest, 1994.

Kiss András: Oklevéltár Kolozsvár történetéhez 1592-ig. Kézirat.

Kiss Andrei: Locurile de adeverire $=$ Kiss, Andrei: Locurile de adeverire din Transilvania în timpul secularizării lor. In: Revista Arhivelor LXXI. Vol. LVI. 1/1994. 58-67.

Kiss: Más források = Kiss András: Más források - más értelmezések. Marosvásárhely, 2003.

KmJkv = A kolozsmonostori konvent jegyzőkönyvei I-II. (1289-1556). Kivonatokban közzéteszi és a bevezető tanulmányt írta Jakó Zsigmond. Budapest, 1990.

Kolozsvári emlékírók = Kolozsvári emlékírók 1603-1720. A bevezető tanulmányt írta és az időrendi áttekintést összeállította Bálint József. A forrásokat válogatta és jegyzetekkel ellátta Pataki József. Bukarest, 1990. 
Korai magyar történeti lexikon (9-14. század). Főszerk. Kristó Gyula. Szerk. Engel Pál és Makk Ferenc. Budapest, 1994.

Kota Péter: Káptalani, megyei, városi jegyzók a XVI-XVII. századi Szombathelyen. In: Vas megyei levéltári füzetek 9. Elöadások Vas megye történetéröl III. Szombathely, 2000.

Kovács András: Kolozsmonostor. Római katolikus kálvária templom. Erdélyi müemlékek 27. Kolozsvár, 1997.

Kovács Kiss: Végrendeletek = Kovács Kiss Gyöngy: Végrendeletek Kolozsvár város levéltárában. In: Megidézett múlt. Tanulmányok, forrásközlések. Kolozsvár, 2008.

Kőfalvi Tamás: A hiteleshelyek mint a magyarországi közjegyzőség előzményei. In: 700 éves a közjegyzőség Magyarországon. A 2008. november 27-i jubileumi konferencián elhangzott előadások szerkesztett változata (szerk. Rokolya Gábor). Budapest, 2008. 12-25.

Köfalvi Tamás: A hiteleshelyi oklevelek egyháztörténeti tanulságai. In: Egyháztörténeti Szemle 1 (2000). 1. sz. 61-64.

Kruppa Tamás: Nagyvárad jelentősége a Báthoryak müvelődés-és valláspolitikájában. In: Századok 139 (2005). 4. sz. 945-968.

Kubinyi-Fügedi: A budai káptalan = Kubinyi András - Fügedi Erik: $A$ budai káptalan jegyzőkönyve. In: Történeti Statisztikai Évkönyv 1967-1968. Budapest, 1970. 9-59.

Kumorovitz: A leleszi konvent = Kumorovitz Bernát Lajos: A leleszi konvent oklevéladó müködése 1569-ig. In: Turul 42 (1928). 1-39.

Kumorovitz: Levéltár = Kumorovitz Bernát Lajos: A leleszi konvent országos levéltárának története. In: Levéltári Közlemények 10 (1932). 223-255.

Kurta József: Az Öreg Graduál századai Erdélyben. Erdélyi Református Egyháztörténeti Füzetek 8. Kolozsvár, 2002.

Lakos János: A Magyar Országos Levéltár története. Budapest, 2006.

Lőwy Dániel-Demeter V. János-Asztalos Lajos: Kőbe írt Kolozsvár. Emléktáblák, feliratok, címerek. Kolozsvár, 1996.

Lupescuné Makó Mária: Erdélyi késő középkori nemesi végrendeletek tárgytörténeti tanulságai. In: Emlékkönyv Kiss András születésének nyolcvanadik évfordulójára. Kolozsvár, 2003. 317-330.

Magyar Törvénytár. 1526-1608. évi törvényczikkek. Fordították és utalásokkal ellátták Dr. Kolosvári Sándor és Dr. Óvári Kelemen. Budapest, 1899.

Makkai: Rákóczi György = Makkai László: I. Rákóczi György birtokainak gazdasági iratai (1631-1648). Budapest, 1954. 
Oborni Teréz: Izabella királyné erdélyi udvarának kezdetei (1541-1551). In: Történelmi Szemle 2009/1. 21-43.

Pakó László: Városi polgár-vármegyei nemes? Nemesek ingatlanszerzése Kolozsváron a fejedelemség korában. In: A reneszánsz Kolozsvár. Kolozsvár, 2008. 222-255.

Pakó László: Rolul adunării centumvirilor în activitatea judecătorească a Clujului în cea de-a doua jumătate a secolului al XVI-lea. In: Pe urmele trecutului. Profesorului Nicolae Edroiu la 70 de ani. Coord. Susana Andea, Ioan-Aurel Pop. Cluj-Napoca, 2009. 225-238.

Pakó László: Hatalmi konfliktus vagy testületi összefogás? A kolozsvári százférfiak tanácsa és a városi igazságszolgáltatás a 16. század második felében. In: Erdélyi Múzeum LXXII (2010). 3-4. sz. 73-87.

Papp László: A birtokba-iktatás = Papp László: A birtokba-iktatás (statutio) lefolyása. In: Emlékkönyv Szentpétery Imre születése hatvanadik évfordulójának ünnepére. Budapest, 1938. 372-384.

Papp László: A hiteles helyek = Papp László: $A$ hiteles helyek története és müködése az újkorban. In: Palaestra Calasanctiana. A piaristák doktori értekezései az 1932. évtől. 14. szám. Budapest, 1936.

Pécsi: Fejedelmi kancellária = Pécsi Anna: Az erdélyi fejedelmi kancellária kialakulása és okleveles gyakorlata 1571-ig. Budapest, 1938.

Radvánszky Béla: Történelmi levelek a Hédervári levéltárból (második közlemény). In: Történelmi Tár. Budapest, 1880. 686-587 (téves lapszám!).

Sándor Imre: A kolozsvári Farkas-utczai ref. templom régi sírkövei. Kolozsvár, 1913.

Sas Péter: A bonchidai Bánffy-kastély egykori kéziratgyüjteménye. In: Magyar Könyvszemle 2008/1. 56-61.

Schrauf Károly: A bécsi egyetem magyar nemzetének anyakönyve 1453-tól 1630-ig. Magyarországi tanulók külföldön IV. Budapest, 1902.

Sill Ferenc: A vasvár-szombathelyi káptalan hiteleshelyi tevékenysége. In: Levéltári Évkönyv 1. Vas megye múltjából. Szombathely, 1976. 20-60.

Sipos: Kollégiumi könyvtár = Sipos Gábor: $A$ kolozsvári református kollégium könyotára a XVII. században (Olvasmánytörténeti Dolgozatok I.). Szeged, 1991.

Sipos: Kolozsmonostor $=$ Sipos Gábor: A kolozsmonostori konvent hiteleshelyi működése. In: Művelődéstörténeti tanulmányok. Bukarest, 1979. 33-50.

Solymosi László: A bencés konventek hiteleshelyi oklevéladásának kezdetei. In: Mons Sacer 996-1996. Pannonhalma ezer éve I. Pannonhalma, 1996. 481-498. 
Solymosi László: Az egri káptalan dékánválasztási statútumai a XV. századból. In: Levéltári Közlemények 63 (1992). 1-2. sz. 137-156.

Solymosi László: Die glaubwürdigen Orte (loca credibilia) Ungarns im 14-15. Jahrhundert. In: Archiv für Diplomatik 55 (2009). 175-190.

Sunkó: Archontológia = Levélkeresők. A Gyulafehérvári Káptalan és a Kolozsmonostori Konvent requisitorainak archontológiája a XVI-XVII. században. In: Fons XI (2004). 2. sz. 277-327.

Sunkó: A Gyulafehérvári Káptalan = Sunkó Attila: A Gyulafehérvári Káptalan és a Kolozsmonostori Konvent Levéltárának müködésére vonatkozó iratok. In: Lymbus. Magyarságtudományi forrásközlemények. Budapest, 2003. 75-110.

Sunkó: Debreceni János = Sunkó Attila: Debreceni János életpályája. A Gyulafehérvári Káptalan levéltárosának élete, végrendeletének tükrében. In: Fons IX (2002). 1-3. sz. 305-343.

Süttő Szilárd: Datum és actum késő Anjou-kori uralkodói okleveleinkben. In: Studia Miskolcinensia 3. Történelmi Tanulmányok. Miskolc, 1999. Digitalizált változat: http://mek.niif.hu/02000/02097/html/sutto.htm

Szabó István: Jobbágyok-parasztok. Értekezések a magyar parasztság történetéből. Sajtó alá rendezte és a bevezetést írta Für Lajos. Budapest, 1976.

Szabó Károly: Nagy-váradi káptalan XVI. századi egyház kincsei. In: Archaeologiai Értesítő XII (1878). 261-262.

Szabó T. Attila: A Wesselényi-levéltár és XVI. századi magyar iratai. In: Levéltári Közlemények 16 (1938). 205-235.

Szabó T. Attila: Egy 1552-i mezőségi szövegemlék és nyelvjárástörténeti adalékai. In: A szó és az ember. Válogatott tanulmányok, cikkek II. Bukarest, 1971. 495-496.

Szabó T. Attila: Hivatal; hivatalos. In: A szó és az ember. Válogatott tanulmányok, cikkek II. Bukarest, 1971. 127-128.

Szabó T. Attila: Nem vagyok káptalan. In: A szó és az ember. Válogatott tanulmányok, cikkek II. Bukarest, 1971. 49-51.

Szabó-Tonk: Egyetemjárás = Szabó Miklós-Tonk Sándor: Erdélyiek egyetemjárása a korai újkorban 1521-1700. Szeged, 1992.

Szakály Ferenc: A szekszárdi konvent hiteleshelyi és oklevéladó müködése 1526-ig. In: Tanulmányok Tolna megye történetéből I. Szerk. Puskás Attila. Szekszárd, 1968. 9-60.

Siralmas krónika = Szalárdi János siralmas magyar krónikája. Sajtó alá rendezte, a bevezető tanulmányt és a jegyzeteket írta Szakály Ferenc. Budapest, 1980. 
Szende Katalin: Otthon a városban. Társadalom és anyagi kultúra a középkori Sopronban, Pozsonyban és Eperjesen. Budapest, 2004.

Szentpétery Imre: Az erdélyi okleveles gyakorlat jellege. In: Turul 1941. 1-2. füzet. 1-10.

Szentpétery: Oklevéltan = Szentpétery Imre: Magyar oklevéltan . Budapest, 1930.

SzT = Erdélyi Magyar Szótörténeti Tár I-XIII. Anyagát gyűjtötte és szerk. Szabó T. Attila (et alii). Bukarest-Kolozsvár, 1975-2009.

Takács Imre: A magyarországi káptalanok és konventek középkori pecsétjei. Müvészettörténeti tanulmány és katalógus a Magyar Tudományos Akadémia Művészettörténeti Kutató Intézete és a Budapesti Történeti Múzeum másolatgyüjteménye alapján. Budapest, 1992.

Takács: Pecsétnyomó = Takács Imre: A kolozsmonostori konvent pecsétnyomója 1575-ből. In: Korunk 2001 július. (elektronikus változata: http://epa. oszk.hu/00400/00458/00043/monostor.htm)

Teleki Mihály levelezése III. 1664-1666. (szerk. Gergely Sámuel). Budapest, 1907.

Torda város tanácsi jegyzókönyve. Bevezető tanulmánnyal és jegyzetekkel közzéteszi Wolf Rudolf. Erdélyi Történelmi Adatok VI. 1. Kolozsvár, 1993.

Tringli István: Megyék a középkori Magyarországon. In: Honoris causa. Tanulmányok Engel Pál tiszteletére (szerk. Neumann Tibor és Rácz György). Budapest-Piliscsaba, 2009. 487-518.

Tripartitum = Werbőczy István Hármaskönyve. Az eredetinek 1517-iki első kiadása után fordították, bevezetéssel és utalásokkal ellátták Dr. Kolosvári Sándor és Dr. Óvári Kelemen. Budapest, 1897.

Trócsányi Zsolt: Habsburg-politika és Habsburg-kormányzat Erdélyben 1690-1740. Budapest, 1988.

Trócsányi Zsolt: Törvényalkotás = Törvényalkotás az Erdélyi Fejedelemségben . Budapest, 2005.

Trócsányi: Kormányhatósági levéltárak = Trócsányi Zsolt: Erdélyi kormányhatósági levéltárak. Budapest, 1973.

Trócsányi: Központi kormányzat = Trócsányi Zsolt: Erdély központi kormányzata 1540-1690. Budapest, 1980.

Tüdős S. Kinga: Erdélyi testamentumok II. Erdélyi nemesek és föemberek végrendeletei. Marosvásárhely, 2005.

Úriszék = Úriszék. XVI-XVII. századi perszövegek (szerk. Varga Endre). Budapest, 1958. 
Varga Árpád: A váradi káptalan hiteleshelyi működése. In: Művelődéstörténeti tanulmányok. Bukarest, 1980. 20-35.

Varga János: Földeskü - Határviták lezárása a 12-15. században. Székfoglalók a Magyar Tudományos Akadémián. Budapest, 2000.

Varga János: Jobbágyrendszer a magyarországi feudalizmus kései századaiban 1556-1767. Budapest, 1969.

Vass Miklós: Székely oklevelek a XVI. századból. Első közlemény. In: Történelmi Tár 1910. 121-143.

Vekov Károly: A gyulafehérvári káptalan hiteleshelyi tevékenysége és a 16. századi szekularizációja. In: Loca credibilia. Hiteleshelyek a középkori Magyarországon (szerk. Fedeles Tamás-Bilkei Irén). Pécs, 2009. 131-141.

Vekov Károly: Egy erdélyi püspök és a gyulafehérvári székesegyház kincstára. In: Emlékkönyv Jakó Zsigmond születésének nyolcvanadik évfordulójára. Kolozsvár, 1996. 525-548.

Vekov: Alba Iulia = Vekov, Károly: Locul de adeverire de la Alba Iulia (secolele XIII-XVI.). Cluj-Napoca, 2003.

Vekov, Károly: Despre evidența documentelor în cadrul locului de adeverire din Alba Iulia. In: Pe urmele trecutului. Profesorului Nicolae Edroiu la 70 de ani (coord. Susana Andea, Ioan-Aurel Pop). Cluj-Napoca, 2009. 103-114.

Dr. Veress Endre: Zalánkeményi Kakas István. Magyar Történelmi Életrajzok (szerk. Dézsi Lajos). Budapest, 1905.

W. Kovács András: Administrația comitatului Hunedoara în Evul Mediu. In: Sargetia. Acta Musei Devensis. XXXV-XXXVI (2007-2008). 203-240.

W. Kovács András: Megyeszékhelyek a középkori Erdélyben. In: Emlékkönyv Egyed Ákos születésének nyolcvanadik évfordulójára. Kolozsvár, 2010. 177-187. 



\section{KÉPMELLÉKLET}

1. A jelenlegi XX. protocollum címlapja (Szőlősi István requisitor bejegyzésével)

2. A jelenlegi XXI. protocollum régi kódex felhasználásával készült borítója

3. Pálfi István 1655-ben kelt beadványának részlete (KmProt XXXV.)

4. 1585-ben kelt bejegyzés a XV. protocollumból

5. Részlet a XXVII. protocollumból, Pálfi István 1630-ban kelt bejegyzésével

6. Tordai Péter requisitor 1630. évi bejegyzése a XXX. protocollumból

7. Részlet a XXXIII. protocollumból, Kászoni József requisitor 1652-ben kelt bejegyzéseivel

8. Szamosközi Mihály requisitor 1661. évi bejegyzései a XXXVI. protocollumból

9. Szőlősi Gábor requisitor 1656. évi bejegyzései a XXXVII. protocollumból

10. Részlet a Szalárdi János által vezetett jegyzőkönyvből (KmProt XXXVIII.)

11. Részlet a jegyzőkönyvek Szalárdi által összeállított mutatójából (KmProt XVIII.) 


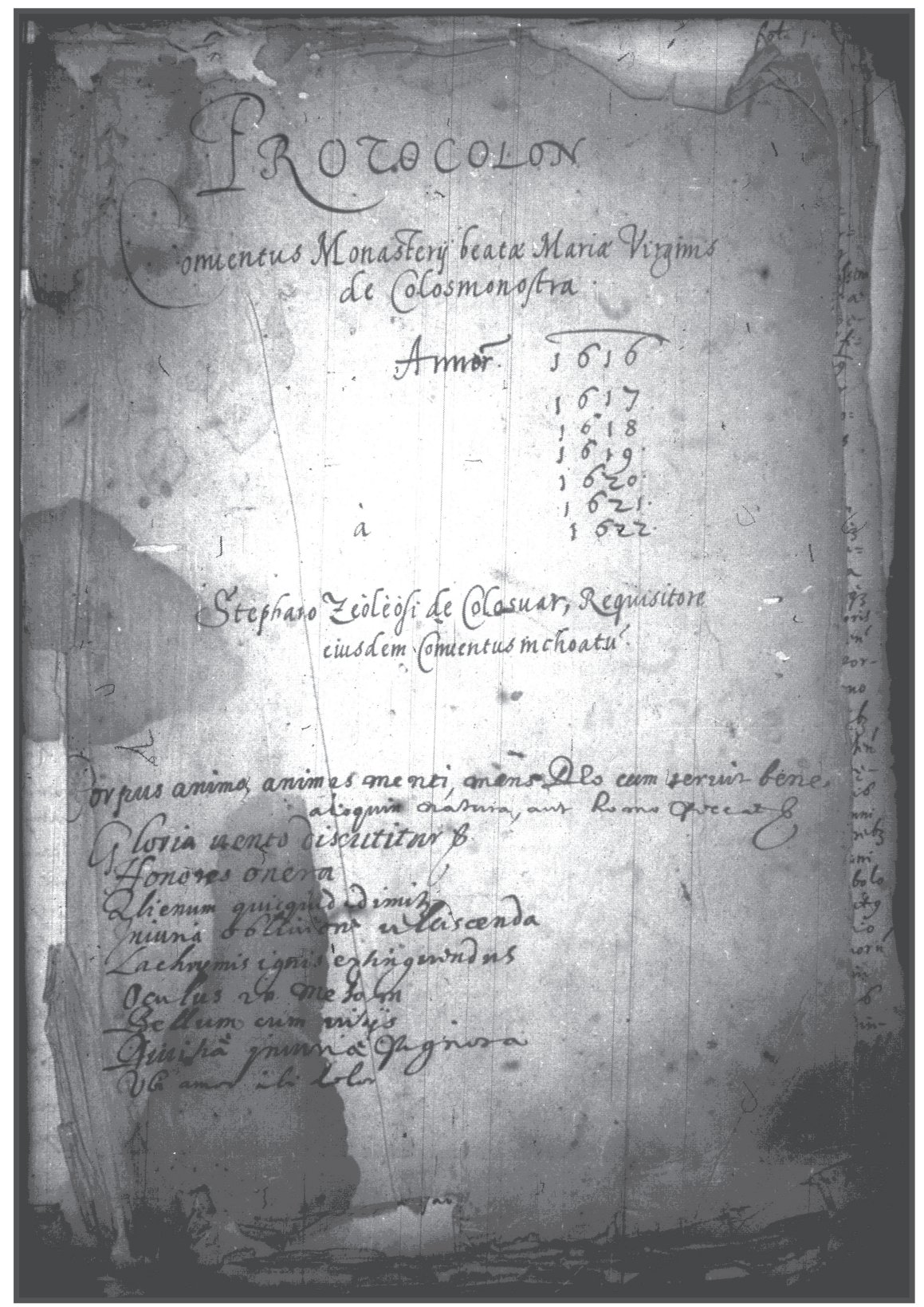

1. melléklet 


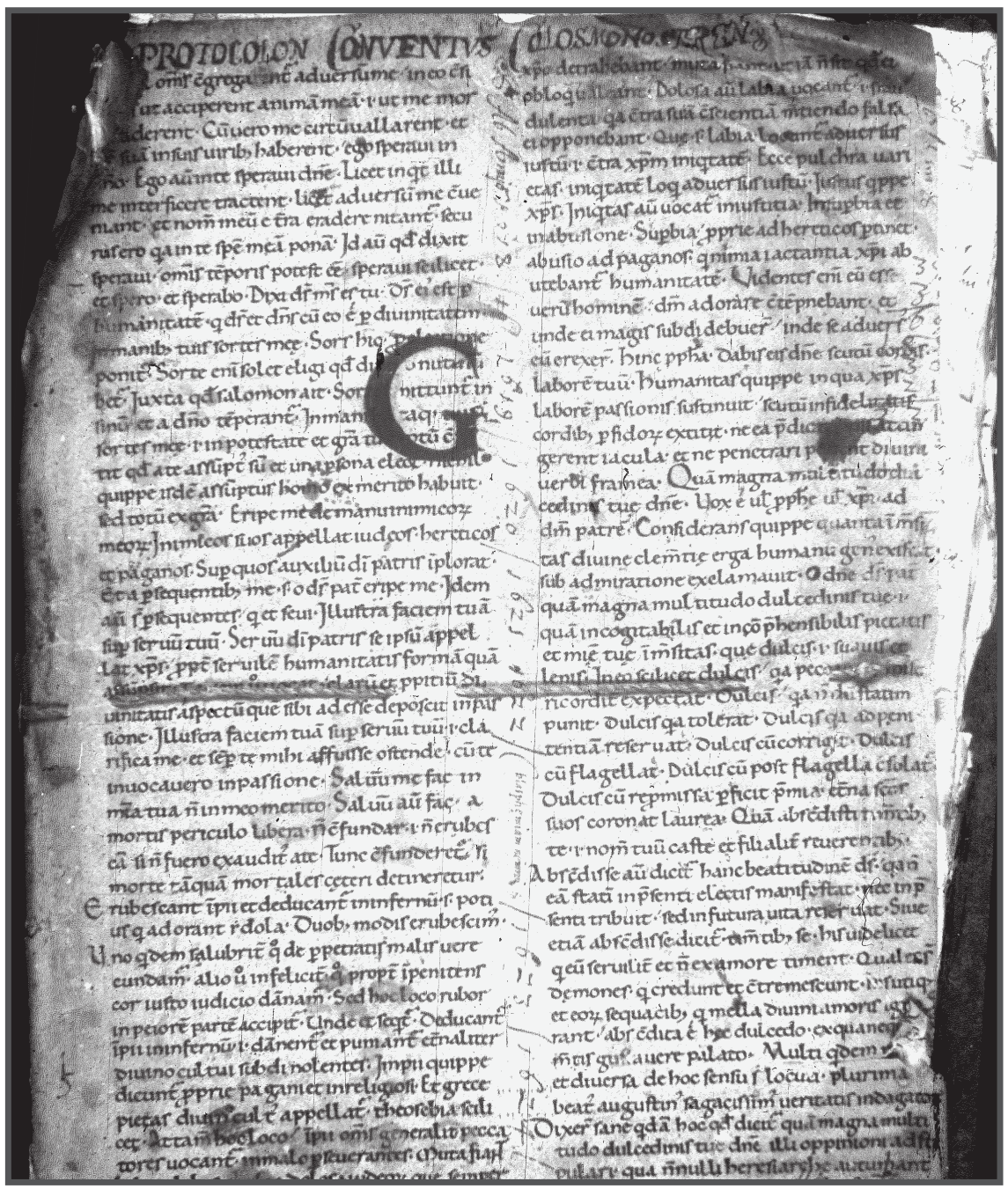

2. melléklet 


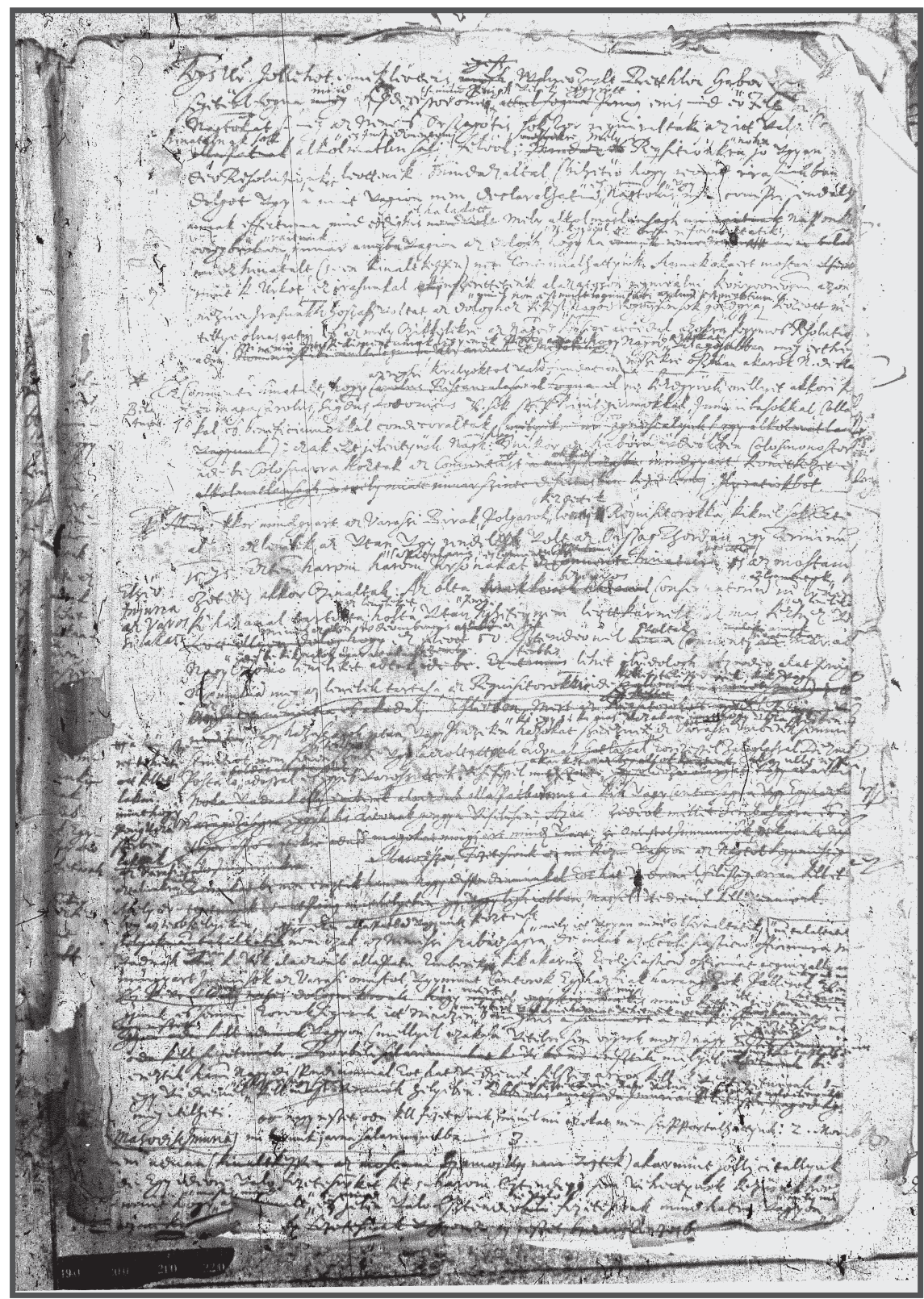

3. melléklet 


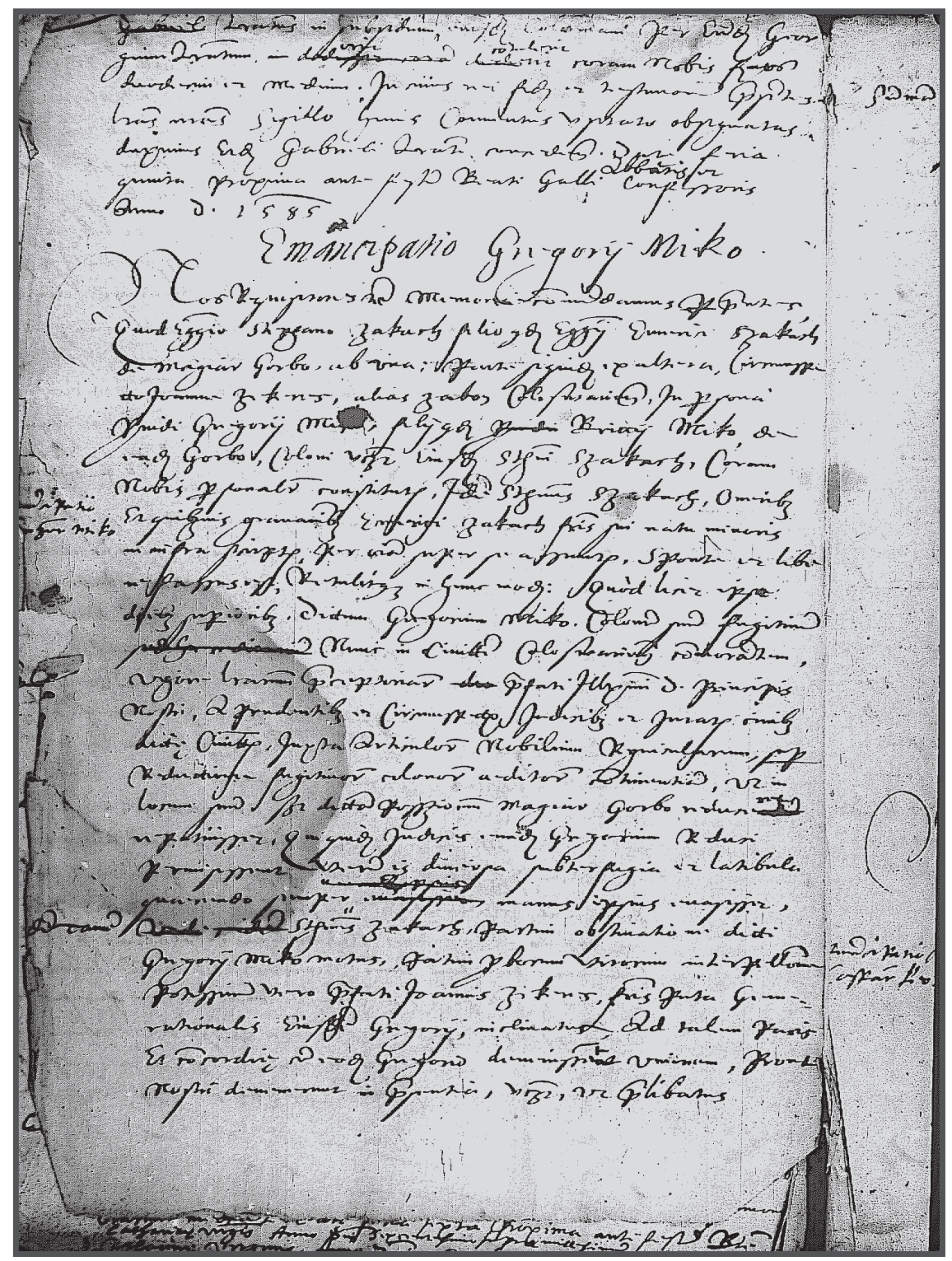

4. melléklet 


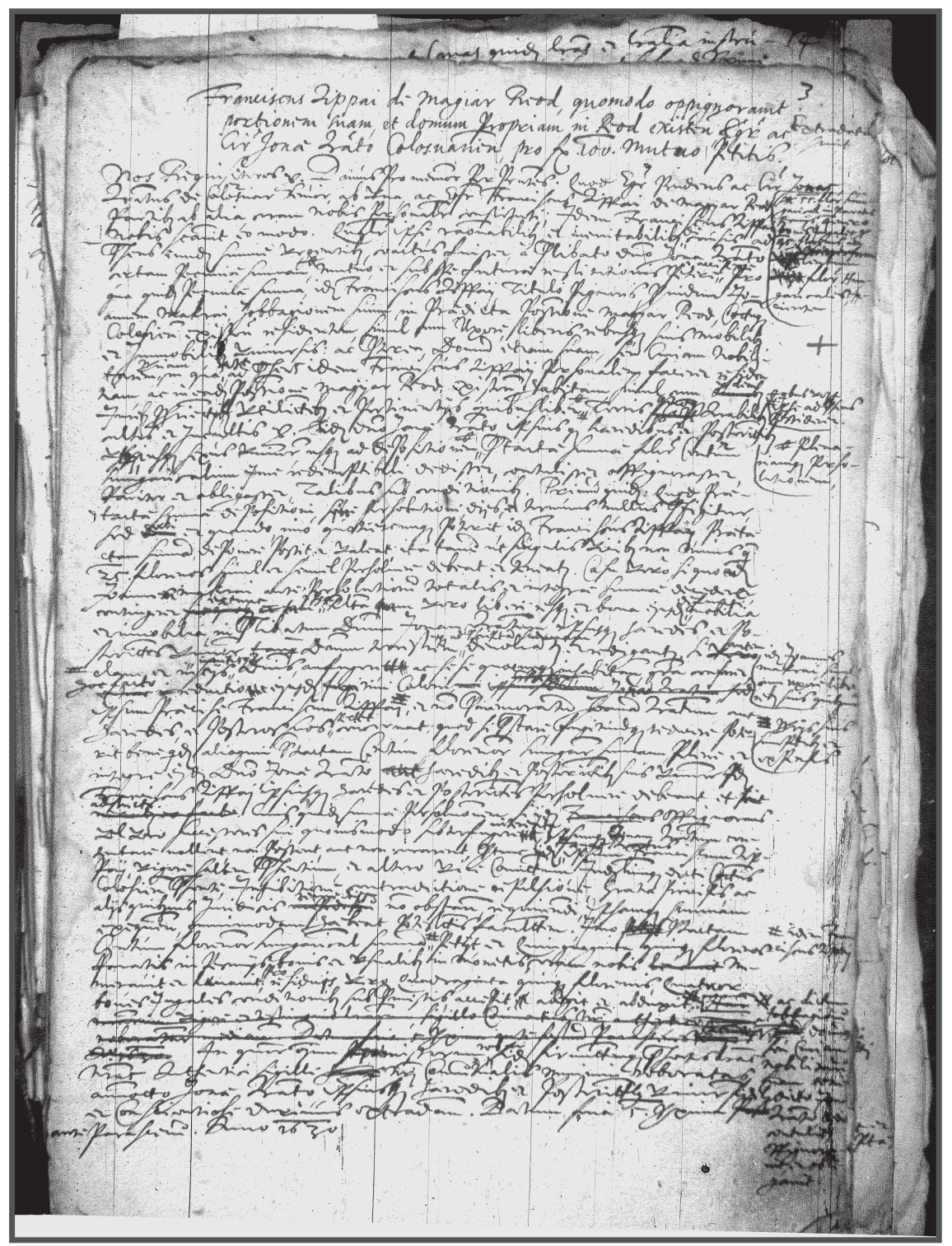

5. melléklet 


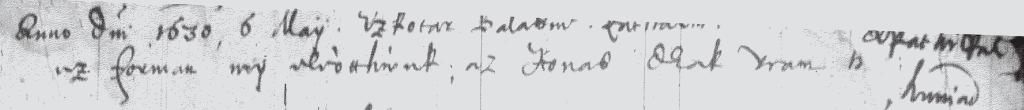

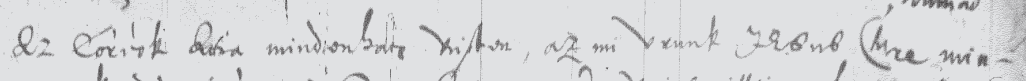

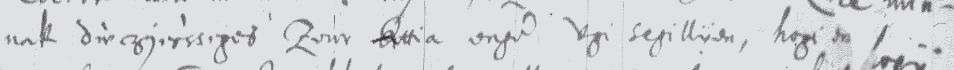

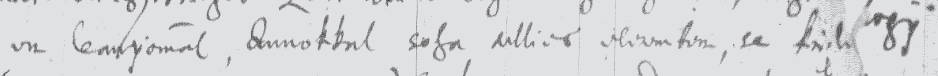

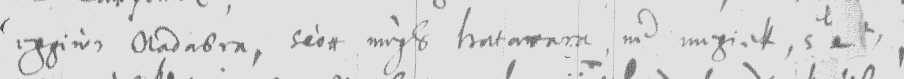

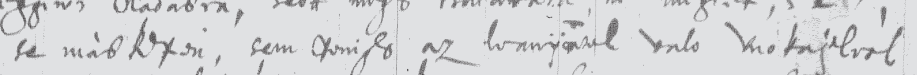

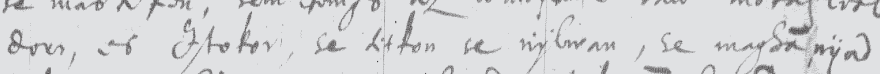

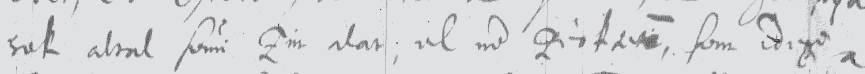

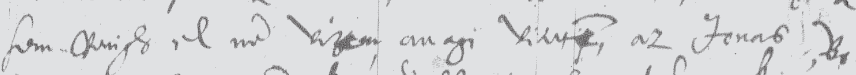

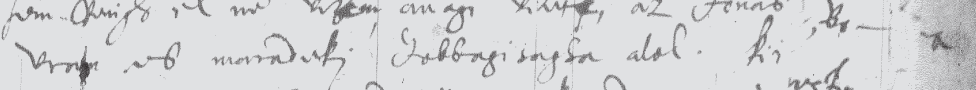

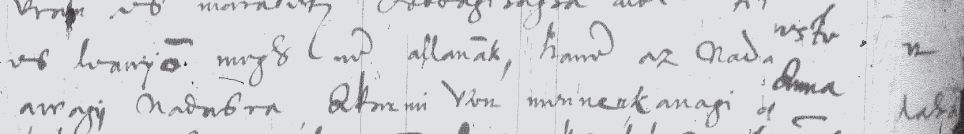

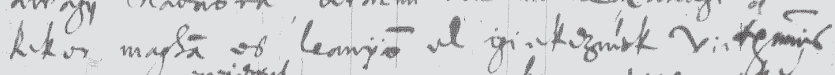

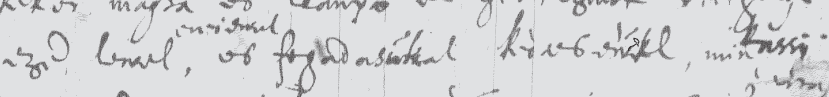

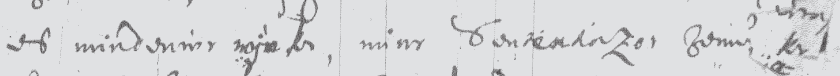

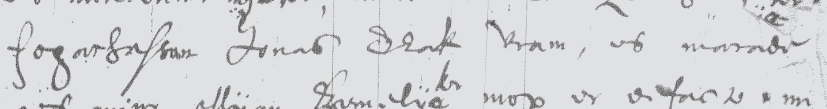

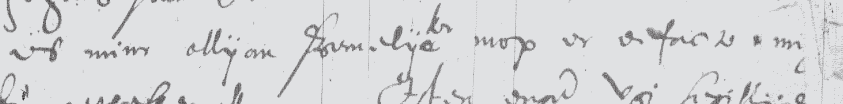

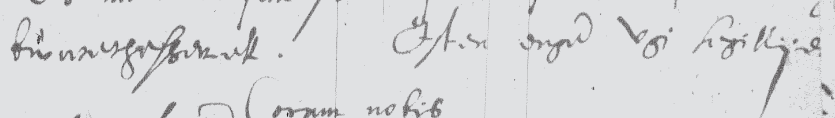

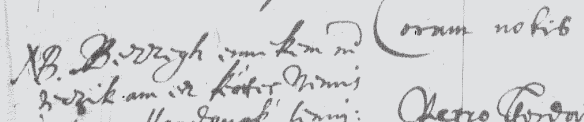

vition allawis ons

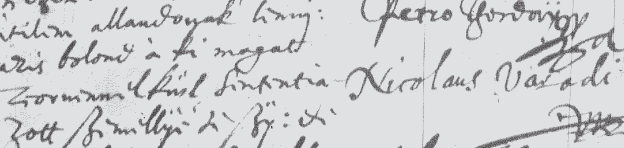

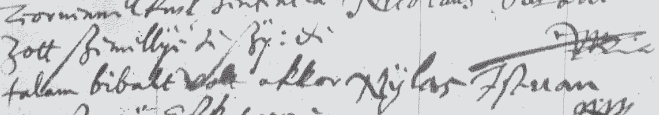

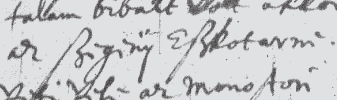
Zfint ar monoton

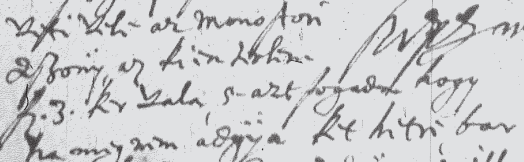

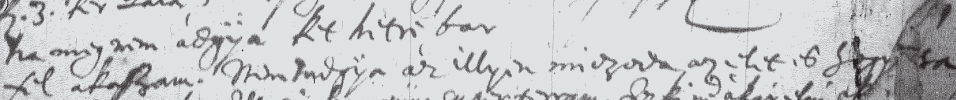

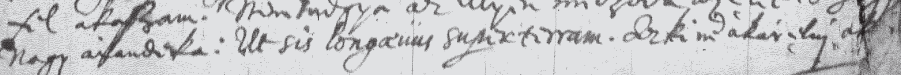




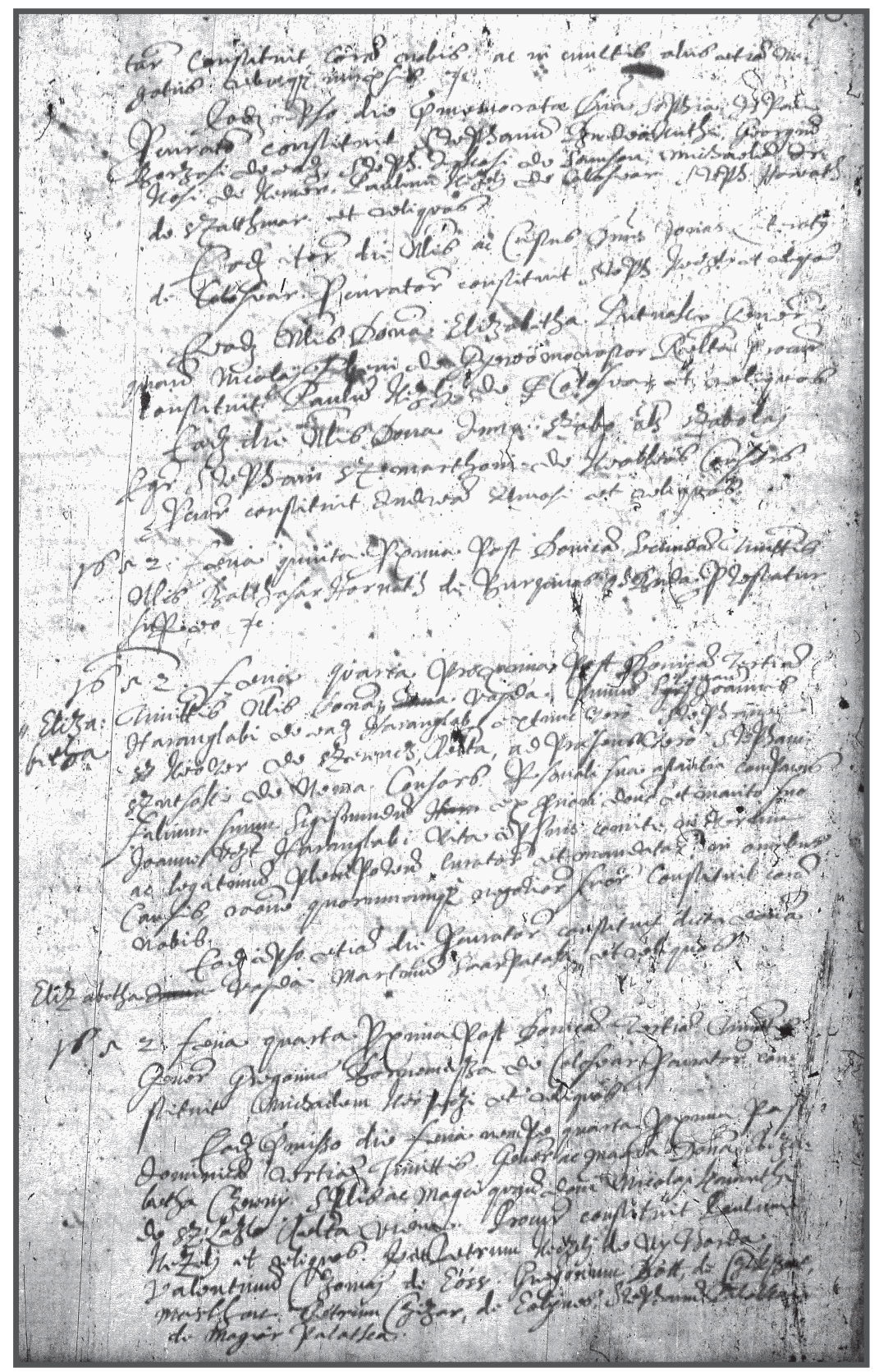

7. melléklet 


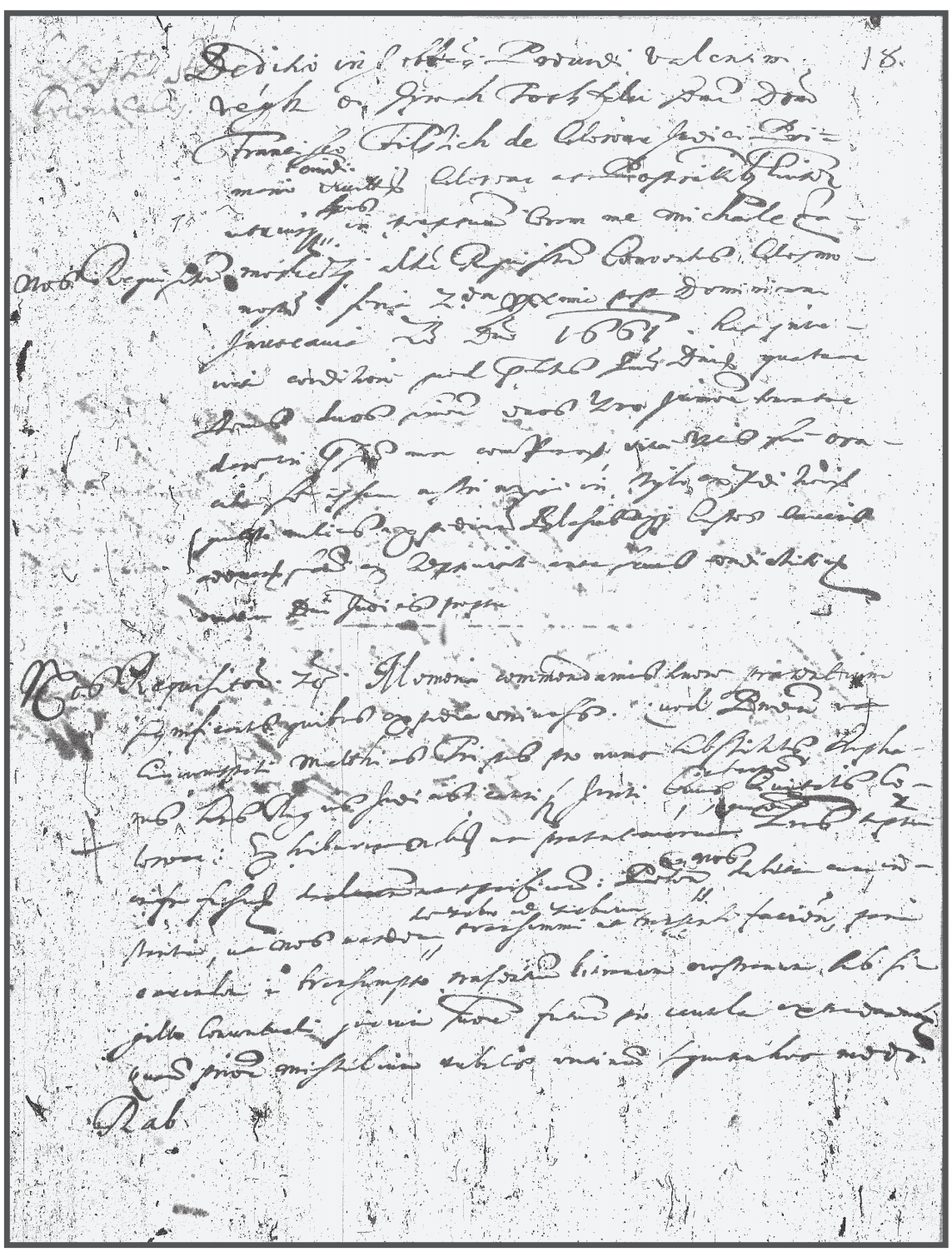

8. melléklet 


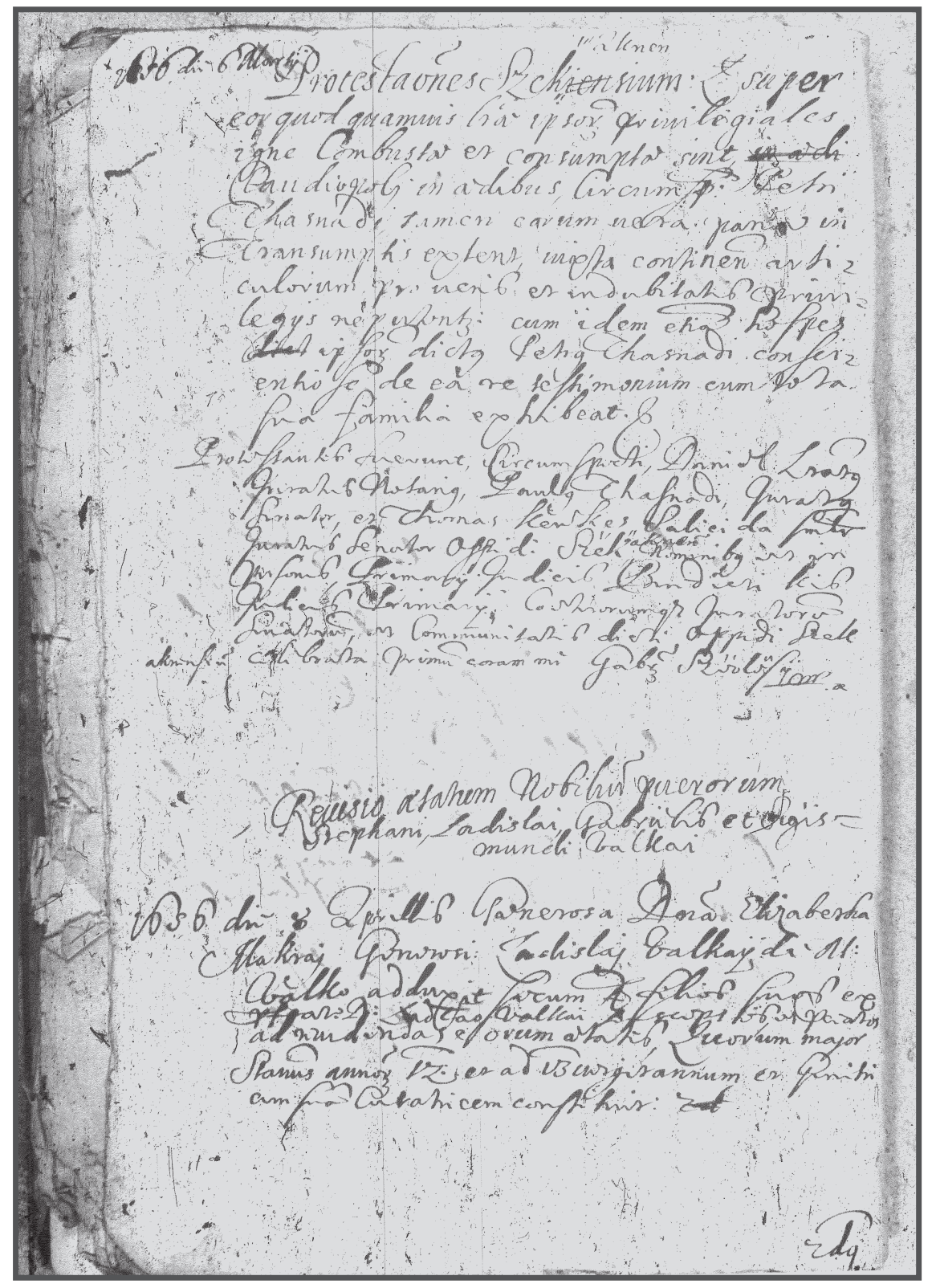

9. melléklet 


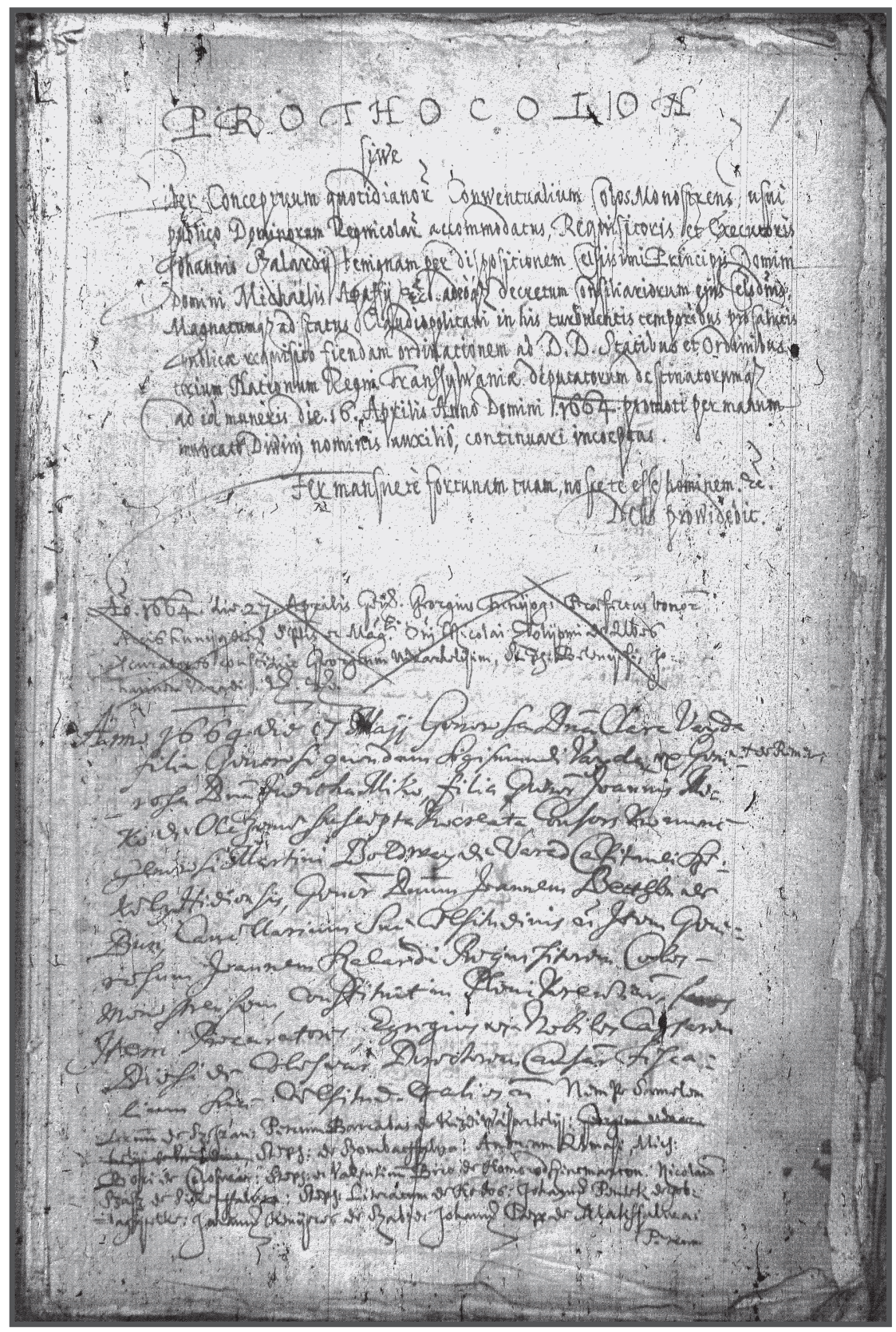

10. melléklet 


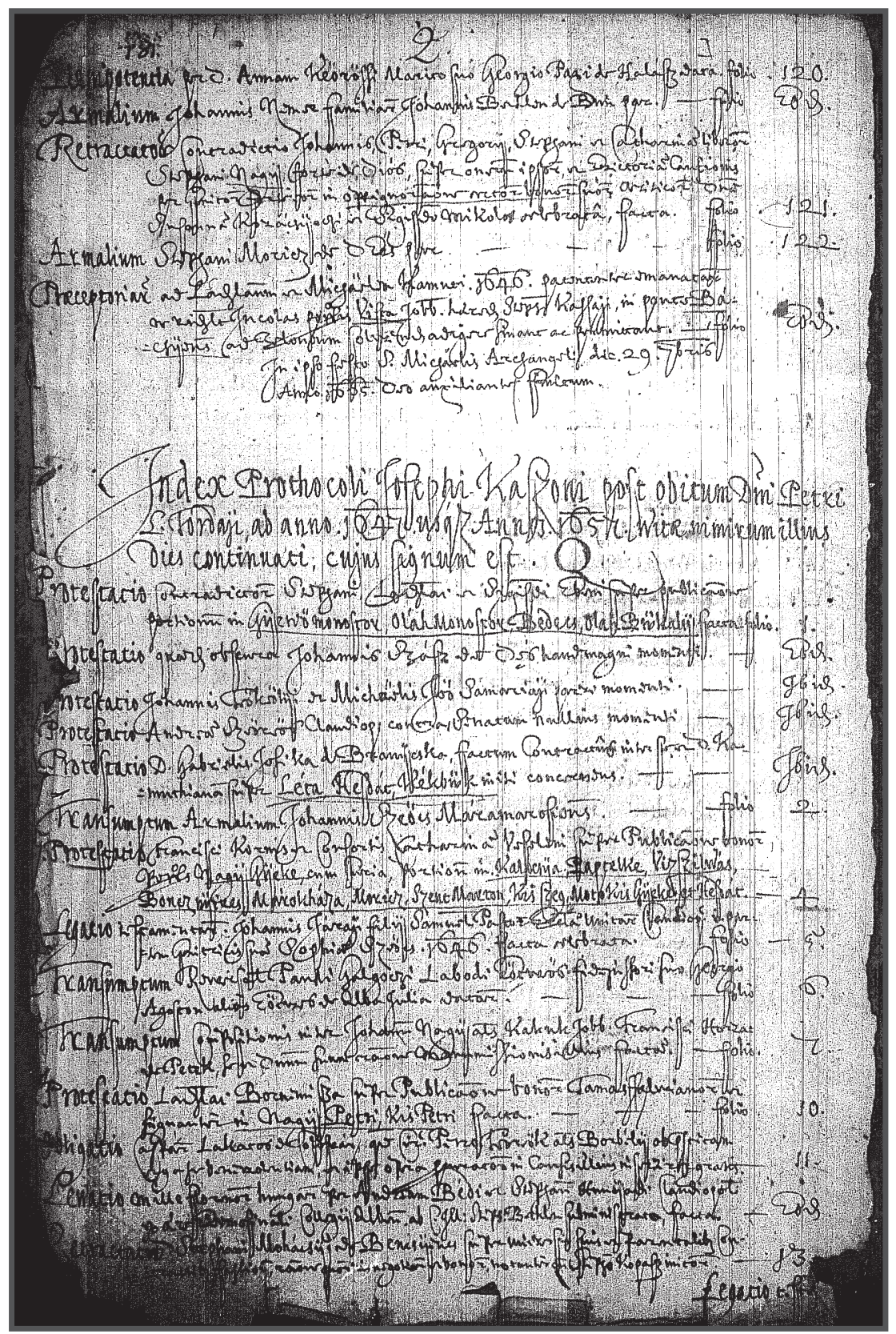

11. melléklet 


\section{SZEMÉLY- ÉS HELYNÉVMUTATÓ}

A kötethez készült mutató tartalmazza a szövegben előforduló öszszes hely- és személynevet, a felhasznált könyvészeti és kéziratos források jegyzékében előfordulók kivételével. A helynevek a történetileg kialakult magyar nyelvű alakjukban jelennek meg, majd zárójelben következik a helység mai hivatalos neve. A településeknél a mutató a fejedelemség kori közigazgatási egység neve után / jellel a jelenlegi megyebeosztást is megadja.

\section{Alkalmazott rövidítések}

alisp = alispán

B-Naszód = Beszterce-Naszód

B-Szoln = Belső-Szolnok

cs $=$ család

föesp = föesperes

$\mathrm{h}=$ helység

isp = ispán

K-Szoln = Közép-Szolnok

$\mathrm{m}=$ megye

M = Magyarország

$\mathrm{mv}=$ mezőváros

$\mathrm{n}=$ nemes

sz = szék, született 
Abosfalva (Abuş), Küküllő/Maros m, h 43

Abrudbánya (Abrud), Fehér m, mv 94

Ajtony (Aiton), Kolozs m, h 150

Ajtonyi Jakab, tordai sókamarás (1621) 117, 120

Akna (Ocna Dejului), B-Szoln/Kolozs $\mathrm{m}, \mathrm{mv} 149$

Albert deák, Bihar vm jegyzője (1561-1572), váradi requisitor (1566-1572) 26-27, 66

Almás (Almaşu), Kolozs/Szilágy m, vár és uradalom 149

Alsó Király utca, utcanév, Kolozsvár 82

Alsóapsa (Gyibrova, Ukrajna), Máramaros m, h 59, 93, 142

Alsófüld (Fildu de Jos), Kolozs/Szilágy $\mathrm{m}, \mathrm{h} 39$

Alsójára (Iara), Torda/Kolozs m, h 140

Altdorf, bajor város Nürnberg közelében 94

Alvinci András, dési sókamarás (1645-ig) 149

András deák 111

András deák, a gyulafehérvári káptalan requisitora (1575-től) 46

Angyalos János, kisebb kancelláriai íródeák (1585, 1588-1592), ítélőmester $(1610,1621) 81$

Apafi, n cs: György és Ferenc 127; Mihály, erdélyi fejedelem (1661-1690) 10, 53, 56-57, 168

Apahida (Apahida), Kolozs m, h 117, 123

Aranyos, székely sz 78, 82

Aranyospolyán (Poiana), Tordába beolvadt település 74

Aranyosrákos (Vălenii de Arieş), Aranyos sz/Kolozs m, h 94
Argenti, Giovanni (1561 körül 1629), erdélyi jezsuita misszionárius, a jezsuita kollégium rektora 106

Árkosi Benedek, gyulafehérvári káptalani requisitor (1659-1664) 54

- Mihály, a kisebb kancellária íródeákja (1639), nagyobb kancelláriai íródeák (1641-1655) 143

Auner Márton 1. Borbély Márton

Bács (Baciu), Kolozs m, h 39

Bácsi István, kolozsvári polgár 87, 158

Bácskai Vera (sz 1930), történész 43

Bácsmegyei Ferenc, Fehér vm alisp (1567), a gyulafehérvári káptalan requisitora $(1580,1582) 47$

Bágyoni János 1. Demeter János

Balásfi, n, polgár, cs: Ambrus, kolozs= monostori requisitor (1577-1591) 61, 63, 74, 77-78, 109, 140; Basilius István (1525 körül-1592), unitárius hitszónok és szerző. Wittenbergben és Jénában tanult, hazatérte után Kolozsváron előbb lektor, majd 1555-től rektor, 1558-tól magyar prédikátor. 1566-ig Rettegen lelkész, majd Tasnádon, Teremiben, Köblösön és Tordán szolgált 77; János (mh 1600), kisebb kancelláriai íródeák (1563), nagyobb kancelláriai íródeák (1577-1586), titkár (1594-1598), gyulafehérvári requisitor (1588-1599) 20, 46, 77-78; Tamás (1580-1625), katolikus hitvitázó, győri kanonok (1607-1617), pozsonyi prépost (1618-tól), váci és pécsi püspök 77

Balázs, a kolozsmonostori konvent szerzetese 161

Balázstelke (Blăjel), Küküllő/Szeben $\mathrm{m}, \mathrm{h} 127$

Bálintffi Kristóf, n, generalis perceptor (1627), Korpád 118, 124 
Ballos István, kolozsvári polgár 124

Balogh Anna, Tordai Imre felesége 80

Balogh Jolán (1900-1988), művészettörténész 25, 76

Bálványosváraljai György, n 162

Bánffy, n cs (Losonci, Zentelkei): János 39; másik János 125; Mihály 107

Bánffyhunyad (Huedin), Kolozs m, mv 152

Barakonyi Sámuel (Enyedi), 1658-ban tatár rabságba került, 1663-ban Fehér vm jegyzője 90

Baranya, vm Magyarország dunántúli részén 88

Baráth István, kolozsvári esküdt polgár 30

Barcsai Ákos (1619-1661), erdélyi fejedelem (1658-1660) 54, 90, 167

- Borbála, n 108

Bárdi István, a gyulafehérvári káptalan requisitora (1647-1666) 167

Barkai Ambrus, a gyulafehérvári káptalan requisitora (1622-1626) 167

Báródság, kerület Bihar vármegyében 118

Barsi Mihály, gyulafehérvári káptalani requisitor (1631-1646), fejedelmi könyvtáros (1634-ig) 105

Basa Mihály, n 162

- Tamás, n 119

Basilius István 1. Balásfi István

Basta, Giorgio (1550-1607), kassai főkapitány (1598-tól), 1601-1604 között Erdélyt kormányozza 121, 124, 127, 140

Báthory, n cs: András (1566-1599), bíboros (1584-1599), varmiai püspök (1589-1599), erdélyi fejedelem (1599) 73; Gábor, erdélyi fejedelem (1608-1613) 28, 55, 80, 153; István (1533-1586), szatmári várkapitány (1557), váradi kapitány (1559?-1571), Bihar vm isp, tanácsúr (1563-1571), erdélyi vajda (1571-1586), lengyel király (1576-1586) 24-25, 32-33, 46, 128, 130; Kristóf, tanácsúr (1569-1570), váradi kapitány (1571-1576), Bihar vm isp (1570-1576), erdélyi vajda (1576-1581) 43, 140; Zsigmond, erdélyi fejedelem (1588-1597, 1598-1599, 1601-1602) 28, 37, 44, $49,75,93$

Bécs (Wien), város Ausztriában 21, 25, 89

Becsiki Anna, n 145

Bek János, kolozsvári polgár 112

- Katalin, Kolozsvári Mártonné 75-76

Beke Antal (1838-1913), levéltáros, történész 8

Bekes Gáspár (1520-1579), János Zsigmond kincstartója és főkamarása (1567-1571), Fogaras örökös isp (1566-1573), Báthory István vajda tanácsura (1573-ig), majd II. Miksa császár kapitánya, utóbb ismét Báthory István híve, lovastestőrségének főkapitánya Lengyelországban (1577-1579) 46, 58, 72

Belső-Szolnok vm 106

Benkő Bálint, a kisebb kancellária íródeákja (1639-1640), Kolozs vm jegyzője (1650-től), kolozsmonostori requisitor (1654-1661) 56, 60, 62, 65, 67-68, 90-92, 94, 167

- Katalin, Benkő Bálint requisitor Conradi Borbálától született leánya 91

Bercsényi Zsuzsanna, Géczi György özvegye 110

Berkeszi Péter, n 130

Berládi Jakab, Rozsás István szolgája, Kolozsvár 116

Besenyő (Viişoara), B-Szoln/B-Naszód m, h 147 
Beszterce (Bistrița), Beszterce sz/B-

Naszód m, v 147, 155

Beszterce vidéke 88

Bethlen, n cs: 143; Anna, Gyulafi Sámuel özvegye 108; Elek, tanácsúr (1680-1690), B-Szoln vm isp (1680-1690) 93; Ferenc 119; Gábor, erdélyi fejedelem (1613-1629) 55, 81-82, 85, 106, 111, 113, 116, 119, 124, 126, 138, 146, 161; István (1582-1648), Bethlen Gábor öccse, kormányzó, majd Erdély fejedelme (1630) 59, 68-69, 84-85, 111, 119, 128; Katalin, Macskási Mihályné 108

Bibarcfalvi János, n 60, 62, 81

Bihar vm 25-26, 39, 45, 66, 118

Bilkei Irén (sz 1954), történész, levéltáros 7

Bíró Vencel (1885-1962), piarista szerzetes, történész 116

Bocskai István (1557-1606), tanácsúr (1581?-1604), vajdai főkamarás (1583-1584), váradi főkapitány és Bihar vm isp (1592-1599), az ország generálisa (1595-1599), B-Szoln vm (1595-1599), ill. Kraszna vm isp (1597-1598), több ízben helytartó, erdélyi fejedelem (1605-1606) 130

Bojti Gáspár, a gyulafehérvári káptalan requisitora (1623-1637), történetíró, Fehér vm jegyzője (1632, 1635) 105

Bologna, város, Olaszország 73

Boncidai János, a nagyobb kancellária íródeákja (1607-1614), 1617-1618 között gazdasági igazgatásban visel tisztséget, 1632-ben svédországi követ 55

Bónis György (1914-1985), jogtörténész 43-44

Borbély Ferenc, polgár, Kolozsvár 77

- Istvánné 163
- János, orvos 126-127

Borbély/Auner Márton, polgár, Kolozsvár 122

Born László, n, Magyargorbó 118

Bornemisza Boldizsár (mh 1608), étekfogómester (1573), 1575-ben Bekes pártjára áll, elmenekül, később kegyelmet kap, huszti főkapitány (1576), Mihály vajdához csatlakozik, Torda vm isp (1601-1602), Fehér vm isp (1598, 1603, 1607), tanácsúr (1599-1600, 1603, 1605, 1607), 1605-ben Bocskai pártjára áll 121-122

- Ferenc és László, Kolozsvár 124

- Gergely, n 106

- János, kolozsvári királybíró (1550, 1556, 1558), főbíró (1559) 30

- Katalin, Bálintffi Kristóf özvegye 132

- Pál, királyi titkár, veszprémi püspök (1549-1553), erdélyi püspök (1553-1556) 21-23

- Tamás, Kolozsvár 126

Bornemisza Benedek 1. Hajósi Benedek

Borsa (Borşa), Máramaros m, h 143

Borsa (Janits) Iván (1917-2006), történész 7-8

Borsoló János, kisebb kancelláriai íródeák (1568), a Magyarországi Részek (Partium) tizedbérlője (1583), ítélőmester (1585, 1587-1591, 1597-1599, 1607) 44

Bölöni/Cerjék Mihály, kolozsi mázsáló, Kolozsvár 121

Böszörményi István, a gyulafehérvári káptalan requisitora (1665-1672) 53

Brini László, Maros sz királybírája (1576, 1580), kővári kapitány (1580-1588), a vajdai udvari lovasok alkapitánya (1583-1584, 
1587-1588), szamosújvári praefectus (1590) 109

Budai Simon deák, a váradi káptalan requisitora (1568-1570) 26

Bunyitay Vince (1837-1915), címzetes váradi püspök, történész 26

C. Tóth Norbert (sz 1974), történész 67

Cegléd utca, utcanév, Debrecen 122

Csakor Ferenc, a kendi vár officiálisa 36

Csáky Mihály (mh 1572), János Zsigmond nevelője, gyulafehérvári dékánkanonok (1532-1533, 1534, $1538,1549)$, hunyadi főesp (1540, 1549), krasznai főesp (1542-1546), püspöki helynök, kir titkár (1549-1550), tanácsúr (1549-1551, 1556-1571), kancellár (1556-1571) és kir helytartó (1565) 20-21, 24, 37,44

Csáky [...], n 149

Csanádi család, Kolozsvár 91

Csanádi János (mh 1575), a nagyobb kancellária íródeákja (1558-1569), kancelláriai titkár $(1567,1569)$, javasolt kolozsmonostori requisitor (1571) 32-33, 62, 70-72

- Pál (mh 1636), a kolozsvári unitárius iskola rektora, orvos, kolozsmonostori requisitor (1625-1636), 1632-től unitárius püspök 47, 61, $63,69,85$

Csapodi Csaba (1910-2004), történész, kézirattáros 118

Cseffei [...], n 150

Cseh (Dezső) Péter és Miklós, Magyarrődi, n 75

- (Rődi) István, n 108

Cserényi Gergely, n, királyi ember 36

Csíksomlyó (Şumuleu), Csík sz/Hargita m, Csíkszeredába beolvadt település 87
Csizmadia Péter 1. Örmény Péter

Csomai Benedek fia, Miklós (Szegedi), közjegyző, kolozsmonostori konventi jegyző (1521-1533), Kolozs megye nótáriusa 67

Csontos Gergely, n 127

Csoronk Ilona, Mosdósi Ambrus fel 22

Czernel Pál (Sárospataki), fejedelmi udvari familiáris (1648) 158

Dáné Veronka (sz 1974), történész 79

Debrecen, Bihar/M, város 122

Debreceni János, a gyulafehérvári káptalan requisitora (1614-1624) 52

Demény Lajos (1926-2010), történész 150

Demeter Dániel, Demeter János fia 82

- János, kolozsmonostori requisitor (1617-1622) 60, 82-83, 139

Dengelegi Péter, íródeák 88

Dés (Dej), B-Szoln/Kolozs m, mv 59, 87, 89-90, 100, 102, 142, 149-150, 159,161

Désfalva (Deaj), Küküllő/Maros m, h 114

Doboka vm 36, 39, 68, 93, 133-135, 146,160

Dobszai István, ítélőmester (1576-1580) 43

Dombai Benedek, a gyulafehérvári káptalan subcustosa (1559-1569), conservatora (1563), requisitor (1573-ig) 22

- Máté, nagyobb kancelláriai íródeák (1589-1593, 1600) 23

Dominkovits Péter (sz 1962), történész 66

Dósa Elek (1803-1867), jogtudós 127

Dőry Ferenc (1875-1960), levéltáros 43 
Dreska Gábor (sz 1973), történész 15, 51,137

Eckhart Ferenc (1885-1957), történész 13

Ember Győző (1909-1993), levéltáros, történész 21

Emődi Tamás (sz 1969), művészettörténész 125

Engel Pál (1938-2001), történész 7, 10, 39,67

Enyed (Aiud), Fehér m, mv 60, 64, 86

Erasmus Adam, a nagyobb kancellária titkára (1609-1618) 130

Erdő Miklós, n 109

Erdős Judit, Kászoni Józsefné 90

- Mihály, dési sókamarás (1645-től) 149

- Mihály, mezővárosi polgár, Dés 90

Farkas utca, utcanév, Kolozsvár 73, $76,87,122,158,162$

Fedeles Tamás (sz 1974), történész 21-22

Fehér vm 47, 59, 90, 110, 133, 135

Fehérvári Ambrus, n 33

Fejér Tamás (sz 1977), történész 153

Fejérd (Feiurdeni), Kolozs m, h 91

Fejérdi cs: Katalin, Márton katolikus vikárius huga 116; Márton, szepesi kanonok, Bethlen Gábor által kinevezett katolikus vikárius (1618-tól) 116

Fejérvári József, polgár, Kolozsvár 122

Fekete Lajos (1891-1969), történész 68

Felsőbánya (Baia Sprie), Szatmár/ Máramaros m, mv 124

Felsőfüld (Fildu de Sus), Kolozs/Szilágy m, h 119

Felsővadász, Abaúj/Borsod-AbaújZemplén m/M, h 107
Felsővisó (Vişeu), Máramaros m, h 143. L. még Visó

Fenesi Borbála, Szőlősi Gábor requisitor özvegye 92

- Mihály, kolozsvári polgár 121

Ferdinánd (I.), magyar és cseh király (1526-1564) 36

Ferdinánd (III.), magyar király (1637-1657) 130

Ferenci Antal, polgár, Kolozsvár 123

Filstich cs, Kolozsvár: Lőrinc, aranybeváltó 125; Péter (mh 1629), kolozsvári ötvöscéhmester, százférfi, senator, aranybeváltó, kamarai prefectus 80,120

Finta $[\ldots] 114$

Forgách Ferenc (1535-1577), váradi püspök (1557-1566), alkancellár (1560-1563), János Zsigmond híveként tanácsúr (1570-1575), kancellár (1571-1575), történetíró 21, 24, 33

Fóris pap (Érsekapáti Kristóf), a váradi Szent István káptalan kanonokja, váradi requisitor (1566-1570) 25-26, 74

Földesi Gáspár, Mihály havaselvi vajda familiárisa 109

Frátai Gergely, táblai ülnök (1563-1570), Kolozs vm isp (1572) 31

Fráter György (1482-1551), pálos szerzetes, Szapolyai János tanácsura (1532-1540), budai udvarbíró és várnagy (1533-1541), kincstartó (1534-1551), váradi püspök (1534-1551), Bihar vm örökös isp (1534-1551), Izabella királyné és János helytartója (1541-1551), illetve Magyarország és Erdély főbírája (1541-1551), bíboros, kinevezett esztergomi érsek (1551) 70

Fruzsina, Erdő Miklós leánya 109

Füzi Margit, n 112 
Gálfi Emőke (sz 1972), történész 47

Gáll Erwin (sz 1977), régész 14

Géczi György (Farnasi), n 110

- István, Kolozsvár 119

Gellyén Imre, kolozsvári polgár 80

Gergely Balázs (sz 1977), régész 14

Gergely Sámuel (1845-1935), történész 160

Gillányi Gergely, tizedfőarendátor (1663-1673) 56

Girolt (Ghirolt), B-Szoln/Kolozs m, h 141

Giróti Margit, Horvát Mátyásné 131

Glezsán Kristóf, n 43

Gyalu (Gilău), Kolozs m, mv és vár 83, 88, 119, 149

Gyeke (Geaca), Doboka/Kolozs m, h 141

Gyerőfi, n cs: Borbála, Tholdalagi Jánosné 127; János, a rendi pénztár fizetőmestere (1597-től), tanácsúr (1614-1615) 107

Gyerővásárhely (Dumbrava), Kolozs m, h 124

Györgyfalva (Gheorghieni), Kolozs m, h 141

Győri Márton, n 118

Gyulafehérvár (Alba Iulia), Fehér m, v $8,11,20,23,27,31-32,35,45,47$, 53, 74, 76, 83-84, 88, 92, 105, 149, $155,159-161$

Gyulaffi László, n 125, 140; Sámuel, Doboka vm isp (1628-tól?), kővári kapitány (1630-tól), K-Szoln vm isp (1631), tanácsúr (1636) 84, 108, 110,148

Haan Lajos (1818-1891), történész 52 Hacaki Ferenc és György, n 115-116 Haczaki Gáspár, Kolozs vm jegyzője (1543), kolozsmonostori konventi nótárius (1543) 67
Hadad (Hodod), K-Szoln/Szilágy m, h és vár 106, 140

Hadnagy János 1. Demeter János

Hagymási Kristóf (1521 körül-1578), tanácsúr (1556-1578), az ország generálisa (1566), váradi főkapitány (1567-től), K-Szoln vm isp (1570-1576) 25

Hagymáslápos (Lăpuşel), Kővár vidéke/Máramaros m, h 148

Hajósi, n cs: Benedek, Pál requisitor apja 79; István, Pál testvére 80; Pál, a kisebb kancellária íródeákja (1588-1599), kolozsmonostori requisitor (1603-1605), Kolozs vm jegyzője (1603?-1605) 60, 62, 67, 79-80

Haller Zsigmond, B-Szoln vm isp (1619) 106

Harangi János, Révai Anna servitora 140

Hatvani István, kolozsvári polgár 145

Havaselvi László, Kolozs vm főszolgabírája (1666) 131

Házsongárdi temető, Kolozsvár 85

Hercegszőlősi János, a gyulafehérvári káptalan requisitora (1638-1650) 104

Herepei János (1891-1970), művelődéstörténész 88, 92, 97

Hesdát (Hăşdate), Doboka/Kolozs m, h 141

Hesdáti Erzsébet, n 121

Híd utca, utcanév, Kolozsvár 84, 110

Horn Ildikó (sz 1963), történész 21, 25,31

Horvát György és István, n, Désfalva 114

- Márton, kolozsmonostori requisitor (1711-től) 63

- Mátyás és leánya: Klára, n 131

Hosszúmező (Câmpulung la Tisa), Máramaros m, mv 142 


\section{Hunyad vm 40}

Ilosvai Benedek (mh 1586), gyulafehérvári elsőpap (1573-1586), a gyulafehérvári káptalan förequisitora és conservatora (1575, 1585-1586), református esperes (1585) 46-47, 74

Inácsi Mihály, n, királyi ember 36 István, kolozsmonostori jegyző 155

Istványi Géza (1913-1943), történész 35, 109

Izabella, magyar királyné, I. (Szapolyai) János felesége (1519-1559) 25, 29-30, 168

Jacobinus János (1574-1603), Kolozsvár jegyzője (1592-1598), kancelláriai titkár (1598-1601), kancellár (1603) 44

Jakab deákné (patikáriusné), polgár, Kolozsvár 97, 160

Jakab Elek (1820-1897), történész 74, 154

Jakab Réka, levéltáros 8

Jakcsi Boldizsár (Kusalyi) és leánya: Zsuzsanna, n 140

Jakó Klára (sz 1962), történész 46, 87

Jakó Zsigmond (1916-2008), történész $7,9,12,70,85,108,133,164$

János (Óvári János) deák, kolozsmonostori requisitor (1560-1575), Kolozs vm jegyzője (1560-1564, 1569-1570) 29-33, 45, 61, 70-72, 157

János, deák 83

János frater, kolozsmonostori apát (1338-1344) 14

János Zsigmond, választott magyar király (1540-1571), Erdély első fejedelme (1556-1571) 22-24, 26-27, 31, 36-37, 42, 44, 50, 76, 129, 159

János, erdélyi alvajda (1296) 14
Jerney János (1800-1855), történész, nyelvész 154

Jeszerniczki János, fejedelmi adószámvevő és fia: György, Gyulafehérvár 120

Jónás deák, n 117

Jövedécsi István 1. Kolozsvári István

Kabos Mihály, n 123

Kádár József (1851-1939), történész 68

Kakas István (mh 1603), kolozsvári számvevő (1564), ítélőszéki ülnök (1589-1590), kancelláriai titkár (1593, 1599), kamarás (1594), diplomata 79

Kákoni István, tanácsúr (1610-1617), kincstartó $(1610,1622)$, tizedfőarendátor (1622) 127

Kakucsi Imre, n 126

Kalmár János, kolozsvári esküdt polgár 33

Kamuthi, n cs: Balázs 116, 127; Farkas 91, 144

Kanizsai János, a váradi káptalan requisitora (1566-1568) 25

Kapi György, n 113

Karándi Miklós, szabados 118

Károlyi Zsuzsanna (1585-1622), Bethlen Gábor fejedelem első felesége 106, 119

Kassai család, Kolozsvár 91, 100, 159

Kassai István, tanácsúr (1613-1644), fiscalis director $(1613,1616)$, ítélőmester (1622-től), kancellár (1634 után) 110, 148, 159

Kastal János, a kolozsmonostori konvent conservatora (1736) 154

Kászoni József, a kisebb kancellária íródeákja (1641-1644), kolozsmonostori requisitor (1646-1659) 56, 59-62, 89-90, 95, 100, 104, 149, 163, 187 
Kaszony (Mezőkaszony/Koszini) Bereg/Ukrajna, mv 60, 89

Katonai Ferencné és Istvánné, n, Kérő 147

Kávási Nagy Gergely 149

Kelemen Judit, Demeter Jánosné 82

Kemény János, Fehér vm főisp (1631-től), kincstartó (1637-1646), táblai ülnök, főgenerális (1645-től), fejedelem (1661-1662) 110-111

Kemény József (1795-1855), forrásgyüjtő, történész $8,47,50$, 74, 77, 154-155

Kend (Corneşti), Doboka/B-Naszód $\mathrm{m}, \mathrm{h}$, vár 36

Kendi Ferenc, erdélyi alvajda (1531), tárnokmester (1539), vajda (1553-1556) 128

- János (Szentiványi), n 71

- Péter, Báthory István udvari familiárisa 128

Kendilóna (Luna de Jos), Doboka/ Kolozs m, h 110

Keresd (Criş), Fehér/Maros m, h 108, 143

Keresztúr (Cristur-Crişeni), Szilágyfőkeresztúr, K-Szoln/Szilágy m, h 43

Keresztyénsziget (Cristian), Szeben sz/m, h 108

Kérő (Băița), B-Szoln/Kolozs m, h 147

Kertész Balázs, kézirattáros 108

Kewy György, n 131

Kibédi János, kisebb kancelláriai íródeák (1589-1599), kolozsmonostori requisitor (1601-1602), Kolozs vm jegyzője (1601-1602) 60, 62, 67, 78-79, 106-107

Kis János, a váradi káptalan requisitora (1598-1599), Bihar vm jegyzője (1599) 66

- Péter, n, Bánffy János familiárisa 125
Kisenyed (Sângătin), Fehér/Szeben m, h 108

Kisfaludi András, nagyobb kancelláriai íródeák (1622), gyulafehérvári káptalani requisitor (1631-1633), váradi udvarbíró (1636-ig) 105

Kiss András (sz 1922), levéltáros, történész 30, 70, 75, 96, 129, 161

Kobori Szabó János, almási udvarbíró (1645-től) 149

Kolosvári Sándor (1840-1922), jogtörténész 36, 139

Kolozs vm 31, 36, 39, 47, 55-56, 66-68, 71, 74, 76, 78-80, 82-84, 87, 90, 93, 131, 136

Kolozsmonostor (Cluj-Mănăştur), Kolozs m, ma Kolozsvár egyik lakótelepe 10, 14, 20, 30-33, 39, 47-48, 63-64, 70, 93, 105, 107, 144, 148, 157, 159

Kolozsvár (Cluj), Kolozs m, v 10, 27, 29-30, 32, 39, 46, 57, 60-61, 63-66, 69-80, 82-84, 87-89, 91-97, 100, 103, 105-106, 109-110, 112-113, 115-117, 119-123, 128, 132-136, 144-145, 148, 153-154, 157-160, 170

Kolozsvári György 76

- György deák 1. Szentiványi György

- János, kolozsmonostori apát (1555-1556) 29

- , n cs: János, tordai (1585, 1590-1591, 1593, 1607), majd vizaknai sókamarás (1601), számvevő (1598-1599), kincstári jogügyigazgató $(1603,1607), 1610-$ ben kivégzik 83, 125; Ferenc, Péter és Erzsébet, Kolozsvári János fiscalis director gyermekei 83

—, n cs: János, Márton fia 76; Márton, Kolozs vm jegyzője (1575-1593), kolozsmonostori requisitor (1575-1600), a fejedelmi tábla 
ülnöke (1593-tól), ítélőmester (1597-1600?) 46-47, 52, 61-64, 67, 73-76; Márton, a requisitor és ítélőmester fia 76

Kolozsvári/Jövedécsi István, kolozsvári polgár 160

Komjáti Mihály, n 10

Konstantinápoly (Isztambul), város Törökországban 75

Kornis Ferenc, n 141

Korpád (Corpadea), Kolozs m, h 118

Kóta Péter (sz 1961), történész 66

Kovács (?) Anna, kolozsvári polgár 107

Kovács András (sz 1946), művészettörténész 14

Kovács Gáspár, kolozsvári polgár 125

Kovács István, Nagyajtai (1799-1872), történész 47, 77

Kovácsi (Făureni), Doboka/Kolozs $\mathrm{m}, \mathrm{h} 91$

Kovacsóczi, n cs: István, tanácsúr (1622?-1634), kancellár (1622-től), Torda vm isp (1627-től) 110, 126; Zsófia, Mikola János felesége 107

Kőfalvi Tamás, történész 7, 13, 18

Königsberg (Kaliningrad), Oroszország, város 94

Körösbánya (Baia de Criş), Zaránd/ Hunyad m, mv 40, 112

Kővár (Chioar), Kővár vidék/Máramaros $\mathrm{m}$, vár és uradalom 88 , 148-149

Kövendi Mátyás, kolozsmonostori requisitor (1593-1614) 61, 63-64, 78-79, 106-107

Közép utca, utcanév, Kolozsvár 73, 124

Közép-Szolnok vm 39, 133-135

Középvisó (Vişeu), Máramaros m, h 143. L. még Visó

Kraszna (Crasna), Kraszna/Szilágy $\mathrm{m}, \mathrm{mv} 127$
Kraszna vm 40, 56, 68, 133-135

Kristó Gyula (1939-2004), történész 7, 10, 171

Kruppa Tamás, történész 25, 79

Kumorovitz Lajos Bernát (1900-1992), történész, levéltáros 165

Kusaly (Coşeiu), K-Szoln/Szilágy m, h 140

Küküllő vm 131

Laki Péter (mh 1703), kolozsmonostori requisitor (1696-1703), a kolozsvári református egyházközség kurátora 64-65, 97

Lakos János (sz 1947), levéltáros 47

Laskai János (mh 1599), gyulafehérvári káptalani requisitor (1580-1590) 32

László (I.), király (1077-1095) 14

László, Kán nembeli, erdélyi vajda és szolnoki isp (1301-1315) 14

Lázár István, n 58

- Istvánné, n 167

- Péter 1. Örmény Péter

Lekence (Lechința), Beszterce sz/BNaszód m, h 147

Lelesz (Leles), Zemplén/Szlovákia, $\mathrm{h}$ 8, 115, 157

Lengyel János, lengyelországi származású szabados, Magyargorbó 118

Lengyelország 73, 118

Lippai Péter, a gyulafehérvári káptalan requisitora (1585-1602) 73, 76

Lisbona János és Henrik 124

Lukács András, gyulafehérvári nagyprépost és őrkanonok 160

Lupescuné Makó Mária (sz 1970), történész 121

Lutz István, kolozsmonostori requisitor (1661-1670), kolozsvári centumvir (1675) 63, 65, 92, 94, 167 
Macskási, n cs: 150; János 150; Mihály 108; Péter 150

Magyargorbó (Gârbău), Kolozs m, h 118

Magyarnádas (Nădăşelu), Kolozs m, h 117

Magyarpata (Pata), Kolozs m, h 60, 79,81

Magyarrőd (Rediu), Kolozs m, h 73, 75-76

Majadi László, a váradi káptalan requisitora (1597-1598), Bihar vm jegyzője (1598) 54

Makk Ferenc (sz 1940), történész 7, 10,171

Máramaros vm 39, 111, 129, 142-143, 146

Maros, székely sz 78

Marosvásárhely (Târgu-Mureş), Maros $\mathrm{sz} / \mathrm{m}$, város 81

Medgyesi Ferenc deák 129

Mediomontanus (oppidum) 1 . Felsőbánya

Meggyesfalva (Mureşeni), Maros $\mathrm{sz} / \mathrm{m}, \mathrm{h} 81$

Megyeri Ferenc 149

Mezőség, tájegység Erdélyben 162

Mihály, havasalföldi vajda (1593-1601), Erdély császári kormányzója (1599-1601) 109

Mikes, n cs 148

Miklós comes, csicsói várnagy (1304) 14

Mikó Fruzsina, Glezsán Kristóf fel 43

Mikola János, n 106

Miske, n cs: András, Barnabás és György 58

Molnár Gáspár, szekeres 78

Monostor utca, utcanév, Kolozsvár 77, 91, 93

Mosdós, Somogy m, h 21-22
Mosdósi, n cs: Ambrus, gyulafehérvári dékánkanonok (1555), requisitor (1559-1568), tizedbérlő (1559-1566) 21-22, 24; János, Mosdósi Ambrus fia 22

Nagy András, kolozsvári vincellér 125

- Gáspár, Szegedi Anna kolozsvári polgár férje 122

- Miklós, kolozsmonostori officiális (1559) 30

Nagy/Havaselvi István, n 112

Nagybánya (Baia Mare), Szatmár/ Máramaros m, v 124, 130, 142

Nagydoba (Doba Mare), K-Szoln/Szilágy $\mathrm{m}$, h 147

Nagyesküllő (Aşchileu Mare), Doboka/Kolozs m, h 125

Nagypatak (Valea Mare de Criş), Bihar m, h 118

Németi, jelenleg Szatmárnémeti (Satu Mare), Szatmár m, mv 130

Neumann Tibor (sz 1978), történész 39,67

Nürnbergi György deák, a kolozsvári szász reformátusok első lelkészének veje 128

Nyilas [...] 141

Nyírő Kálmán, kolozsvári főbíró (1570) 30

- Mihály, kolozsvári polgár 121

Oborni Teréz (sz 1960), történész 12, 21

Offenbánya (Baia de Arieş), Fehér m, mv 112, 125

Oláhkara (Cara), Kolozs m, h 117

Oláhpata (Pata), Kolozs m, h 79

Oláhrőd (Rediu), Kolozs m, h 75

Orbán Ferenc, fejedelmi udvarmester (1649) 114 
Orgonás Benedek, kolozsvári esküdt polgár (1570-1572), centumvir, ispotálymester 30

Orlát (Orlat), Szeben sz/m, h 108

Oroszmező (Rus), B-Szoln/Szilágy m, h 149-150

Óvár, kolozsvári városrész 70, 75

Óvári Kelemen (1844-1925), jogtörténész 36, 139

Ördög Ferenc (Nagyesküllői), n 125

- István, n 91

- János, n 40

Örmény/Lázár/Csizmadia Péter, Kolozsvár 112

Őrmező (Var), Doboka/Szilágy m, h 108,150

Ötvös András, polgár, Kolozsvár 106

Padova, Olaszország, város 85, 94

Pakó László (sz 1980), történész 65, 71, 120

Pál deák 167

Pálfi István, a kolozsmonostori konvent requisitora (1627-1667) 11, 52, 55-57, 59-64, 67-69, 84-87, 89-90, 100, 103-106, 108, 110-112, 114, 130, 137-143, 145, 149, 152-153, 158-160, 162-163, 166, 171, 187

Páll Sámuel (mh 1791), kolozsvári királybíró (1766, 1770, 1779, 1781), főbíró $(1773,1780)$, kolozsmonostori requisitor 65

Pannonhalma, Győr/M, h 154

Pápai Balázs, n 119

- Imre, kisebb kancelláriai íródeák (1571, 1576-1577), gyulafehérvári káptalani jegyző (1579-1583), majd requisitor (1584) 47-48

- János, a gyulafehérvári káptalan requisitora (1650-1657) 54

Papfalva (Popeşti), Kolozs m, h 123
Papp László (1909-1994), piarista, történész 8, 28, 35, 50, 99, 151-152, 164,171

Partium 19, 27, 38-39, 96, 111

Pataki István (1640-1693), külföldi tanulmányok után Bánffy Dénes udvari papja, a kolozsvári református kollégium tanára, II. Apafi Mihály nevelője 97

Patkó János, kisebb kancelláriai íródeák (1609-1610), nagyobb kancelláriai íródeák (1611-1624) 130

Pécs, Baranya/M, város 88

Pécsi András, a kolozsmonostori konvent requisitora (1684) 96

- Anna, történész 41-43

- János, nagyobb kancelláriai íródeák (1622-1633), kolozsmonostori requisitor (1633-1642) 59-60, 62, $64,83,88,107,114,142,147,150$, 167

Pécsváradi János, nagyobb kancelláriai íródeák (1639-1641), kolozsmonostori requisitor (1635-1644) 58, $62,89,153$

Penalosa, Ambrosius de (1589-1656), jezsuita teológus 89

Peres Márton, n 126

Perneszi Miklós, n 109

Petki Ferenc, n 116

Petrovai Jakab, Máramaros vm főszolgabírája (1640) 143

Pézeri Sára, Vicei Gáspár özvegye 106

Piti Ferenc (sz 1971), történész 7

Pogány, n cs: Menyhárt, Máramaros vm alisp (1640) 142; Péter, Máramaros vm alisp (1616) 129

Pokoly József (1866-1933), egyháztörténész, teológus 68

Polgár Ambrus, Kolozsvár városának jobbágya 117

Polgári Bálint 1. Somogyi Bálint

Polgári Mihály 1. Somogyi Bálint 
Polyáni Bálint 1. Somogyi Bálint

Porumbák (Porumbacu), Fehér/Szeben $\mathrm{m}$, h és uradalom 90, 149

Pósai Bertalan, n 128

Pozsony (Bratislava), város Szlovákiában 35

Prága (Praha), város Csehországban 75

Pulacher/Conrad Borbála: Benkő Bálint felesége 91

Puskás Attila, szerkesztő 51

Rácz György (sz 1967), történész 39, 67

Radicsics János, a gyulafehérvári káptalan jegyzóje $(1549,1555)$, requisitor (1559-1566), a fejedelmi tábla ülnöke (1559-1566) 23

Radu Şerban, havasalföldi vajda (1602-1610, 1611) 127

Radvánczy Márton (mh 1597), ítélőszéki íródeák (1577), ítélőmester (1574, 1582-1586, 1588-1590) 43-44, 63

Rákóczi, n cs: György (I.), erdélyi fejedelem (1630-1648) 54-55, 87-88, 105, 107, 131, 145-146, 148-150; György (II.), erdélyi fejedelem (1642-1660) 103, 110, 147, 158-159; Zsigmond (1544-1608), Erdély fejedelme (1607-1608), szendrői főkapitány (1585-1587), Borsod (1588-1591), Bereg (1590-1603), Heves (1592-1595), Abaúj (1598), Torna (1598-1609) vm isp, tanácsúr (1605-1607) 106

Rákosi, n, polgár, cs: Boldizsár, orvos, kolozsmonostori requisitor (1659-1694 előtt) 61, 63, 94; Boldizsár, Ilona 94; Péter, kolozsmonostori requisitor (1696-1711), kolozsvári nótárius (1696) 61, 63, 73, 97-98, 160

Rázmán Anna, Pécsi Jánosné 88
- Péter, kolozsvári polgár, centumvir 112

Réthy László (1851-1914), etnográfus, numizmatikus 68

Révai Anna, Jakcsi Boldizsár özvegye 140

Rhédei Ferenc (1610 körül-1667), tanácsúr (1647-1657), Erdély fejedelme (1657-1658) 59, 90, 92, 149, 155

Rozsás, polgár cs, Kolozsvár: István 116, 145; János, borbély 122

Rőd (Rediu), Kolozs m, h 76. L. még Magyarrőd, Oláhrőd

Rudolf, magyar király (1576-1608) 130

Sándor Gergely, a váradi káptalan requisitora (1567-1569) 26

- Imre (1877-1930), családtörténész, heraldikus 76, 80

Sas Péter (sz 1954), irodalomtörténész 54

Schrauf Károly (sz 1835), történész 21

Segesd (Şaeş), Segesvár sz/Maros m, h 143

Segesvár (Sighişoara), Segesvár sz/ Maros m, v 143

Serédi István, Kraszna vm isp (1635-től), K-Szoln vm isp (1650-es évek), főlovászmester (1635-1638), az országgyülés és a fejedelmi tábla elnöke (1647-1652), tanácsúr (1647-1657) 84

Sill Ferenc (sz 1925), történész, ferences szerzetes 7

Sipos Gábor (sz 1951), levéltáros, történész 12, 133, 158

Sófalva (Sărata), Doboka/B-Naszód $\mathrm{m}, \mathrm{h} 36$

Solymosi László (sz 1944), történész $7,12-13$ 
Sólyomkő (Şoimeni), Doboka/Kolozs $\mathrm{m}, \mathrm{h} 91$

Sombori, n cs: János 31; Judit, Kolozsvári Jánosné 83; László (mh 1590), nagyobb kancelláriai íródeák (1559-1563), táblai ülnök (1570), jogügyigazgató (1572-1579), főtizedbérlő (1575-1590), tanácsúr (1580-1590), a kormányzó tanács egyik tagja (1583-1585) 40, 46, 48, 54,128

Somogyi (Polyáni) Bálint, pap, kolozsmonostori requisitor (1575) $46-47,52,74$

Stenczel Ferenc, kolozsvári polgár 125

Sulyok Imre (mh 1578), nagyobb kancelláriai íródeák (1567-1570), ítélőmester (1574-1575), kancellár (1576-1578), tanácsúr (1577) 45-46, 48

Sunkó Attila, levéltáros, történész 9, $48,70,74$

Susalics Zsigmond, n, Gyerővásárhely 124

Süttő Szilárd (sz 1964), történész 113

Szabó Anna, Szentmártoniné 114

- György, Szalánci Krisztina szolgája, Torda 110

- István (1898-1969), történész 115

- Mátyás és felesége Katalin, Kolozsvár 122

Szabó T. Attila (1906-1987), nyelvész, történész 10, 40, 47

Szakály Ferenc (1942-1999), történész 51

Szalánci Krisztina, n 109

Szalárdi János (1616-1666), kancelláriai íródeák (1633-1638), fejedelmi levéltáros (1638), vicesecretarius (1639-1647), váradi requisitor (1649?-1660), kolozsmonostori requisitor (1664-1666) 54, 57, 60,
62, 64-66, 69, 84, 95-96, 131, 137, $160,163,167-168$

Szamosfalva (Someşeni), ma Kolozsvár egyik lakónegyede 107

Szamosközi István (1570-1612), a gyulafehérvári káptalan requisitora (1602-1612), fejedelmi historikus (1602-1608) 77, 93

- Mihály, nagyobb kancelláriai íródeák (1631-1633), Doboka vm jegyzője (1640-1653), kolozsmonostori requisitor (1656-1661) 60, 62-63, 68, 93, 160, 167, 187

Szamosújvár (Gherla), B-Szoln/ Kolozs m, h és vár 55-57, 87, 95, 100-102, 109, 114, 119, 139, 147-150, 160, 163

Szaniszló Albert, a Toroczkaiak ügyvédje 131

Szapolyai cs 27

Szapolyai János, magyar király (1526-1540), szepesi isp és gróf (1509-1526), Liptó vm isp (1510?-1526), koronaőr (1510?-1526), erdélyi vajda és székely isp (1510-1526), szörényi bán (1514) 42

Szász Anikó (sz 1976), történész 64, 93, 96

Szatmár (Satu Mare), Szatmár m, mv 130

Szeben (Sibiu), Szeben sz/m, város 50, 81

Szécsi Katalin, Prépostvári Zsigmondné 145

Szegedi Anna, kolozsvári polgár 122

- György, Kolozsvár város jegyzője $(1561,1568) 70$

- Zsigmond, Bethlen István szolgája 111

Szék (Sic), Doboka/Kolozs m, mv 150

Székely Illyés 30

- Márton, szabados 118 
- Mózes (1550 k-1603), udvari familiáris $(1583,1589,1593)$, székely sókamarás (1583-1584, 1588, 1591), főhadnagy (1591), tanácsúr (1600-1601), főgenerális (1600), fejedelem (1603) 127, 129

Székelyföld 40, 79, 89, 136

Székesfehérvári Benedek, deák 128

Szemerei György, n 128

Széna utca, utcanév, Kolozsvár 77

Szénás Péter, fejedelmi praefectus (1639-1651), Bihar vm alisp (1633), portai követ (1635), táblai ülnök (1642-1647) 148-149

Szende Katalin (sz 1965), történész 122

Szentegyház utca, utcanév, Kolozsvár 93

Szentiványi Gábor, a nagyobb kancellária titkára (1598 előtt) 77

- György, kolozsmonostori requisitor (1577-1613) 61-63, 74, 76-77, 79, 106, 109, 162

Szentkirály (Sâncrai), Fehér m, h 125

Szentlászló (Laslea), Segesvár sz/ Szeben m, h 143

Szentmárton, Doboka/Kolozs m, puszta Drág közelében 141

Szent-Mihály plébániatemplom, Kolozsvár 158, 160

Szentmihályfalvi András, a nagyobb kancellária íródeákja (1616-1631) 83

Szentmihályi István, kolozsmonostori requisitor (1703) 97, 160

- Lőrinc, a gyulafehérvári káptalan requisitora (1568-1573), gyulafehérvári udvarbíró (1569) 23, 37

Szentpáli András, n 147, 149-150

Szentpétery Imre (1878-1950), történész 19, 46

Szilágycseh (Cehu Silvaniei), KSzoln/Szilágy m, mv 125
Szilvási Boldizsárné, n 114

Szilveszter János, Kolozsvár város jobbágya 117

Szindi Márton, kolozsvári polgár 87, 158 Szlatina (Slatina), Máramaros m, h 143

Szőlősi Gábor (mh 1672), kolozsmonostori requisitor (1654-1657), 1658-ban kolozsvári főbíró, centumvir $(1659,1665)$ 63, 65, 92, 139, 187; Mária, Szőlősi Gábor leánya 92

- István, kisebb kancelláriai íródeák (1607), nagyobb kancelláriai íródeák (1610-1614), a kolozsmonostori konvent requisitora (1616-1623), Kolozs vm jegyzője (1623-1624) 55-56, 60, 62, 68, 80-83, 139, 144, 166,187

- Péter 82

Szőrös Borbála, Rákosi Boldizsár requisitor felesége 94

Szucság (Suceagu), Kolozs m, h 123

Tagányi Károly (1858-1924), levéltáros, történész 68,168

Tahi István, Belső-Szolnok vm isp (1601) 106

Takács Imre (sz 1959), művészettörténész 154-155

Tályai István, kolozsvári jegyző (1557, 1559) 30

Tamásfalva (Tămaşa), Kolozs m, h 108

Tamásfalvi, n cs: Dénes 144; Imre és Miklós 108

Taraczközi Ferenc, a gyulafehérvári káptalan requisitora (1652-1667)160

Técső (Tyacsiv), Máramaros/Ukrajna, város 90

Teke (Teaca), Kolozs/B-Naszód m, h 147 
Teke (Theke) Ferenc (mh 1599), vajdai ítélőszéki jegyző, majd ülnök (1577-1578), kolozsi (1586), dési sókamarás $(1588,1590)$, B-Szoln vm isp (1593-1594, 1599), a rendi pénztár fizetőmestere (1594-1596) 10,75

Telegdi Márton, n 106

Teleki Mihály, tanácsúr (1670-1690), főgenerális 95, 160

Teremi György (Sükösdi), n 116

Tholdalagi, n cs: András, táblai ülnök (1567-1570) 31; János, fiscalis director (1620-as évek közepe-1633), tordai sókamarás (1632), a fejedelmi tábla ülnöke (1638) 84; másik János 127

Tímár János, kolozsvári esküdt polgár 33

Toldi Istók, n 111

Tolnai Miklós, a nagyobb kancellária íródeákja (1559-1570), javasolt kolozsmonostori requisitor (1571) 32-33, 62, 71-72

Tompaháza (Rădeşti), Fehér m, h 129 Topánfalva (Câmpeni), Fehér $m, \mathrm{~h}$ 112

Torda (Turda), Kolozs m, v 19, 25, 33, $39,60,80,110,117$

Torda vm 39, 68, 133-135, 146

Tordai Imre, Kolozs vm jegyzője (1605-1622), kolozsmonostori requisitor (1608-1619) 60-61, 64, 67, 79-80; leányai: Borbála és Anna 80

- Péter, kolozsmonostori requisitor (1623-1646) 58, 61-62, 64, 67-68, 83-84, 88, 95, 108, 110, 114, 150, 162-163, 165, 167, 187

- Péter (másik), n 83

- Péter, nagyobb kancelláriai íródeák (1612) 83
Torma János, a váradi káptalan requisitora (1624-1638), Bihar vm jegyzője (1630) 52

Toroczkai cs 131

Tóth Gergely, Kamuthi Balázs jobbágya 116

Törösdi Mihály, n, Debrecen 116

Tringli István (sz 1960), történész 39, 67

Trócsányi Zsolt (1926-1987), levéltáros, történész $73,98,168$

Túr (Tureni), Torda/Kolozs m, h 123

Túri Mihály, n 116

Türe (Turea), Kolozs m, h 116

Udvarhely (Odorheiu Secuiesc), Udvarhely sz/Hargita m, v 150

Udvarhelyi György, kisebb kancelláriai íródeák (1641-1642), nagyobb kancelláriai íródeák (1646-1648) 90, 162

Újfalu, Tompaházával (Rădeşti) öszszeolvadt település 126

Urbeger Zsófia, Szőlősi Péter anyja 82

Vagyas Gáspár, n, Magyarpata 81

Valentiny Antal (1883-1948), nyelvész, történész 39,44

Valkai Miklós, n 37, 44

Várad (Oradea), Bihar m, v 25-28, 45, $57,66,74,95$

Váradi Lukács, Bihar vm jegyzője (1586-1588), váradi requisitor (1587-1595) 26, 54, 66

- Miklós, kolozsvári polgár, százférfi (1647-1659), vonásigazító (1647-1648, 1653, 1657-1658), számvevő (1645, 1647, 1651, 1653, 1655, 1657), főbíró (1644, 1656), osztóbíró (1657-1658), a kolozsvári református egyházközség főkurátora (1652-1659) 125, 128 
- Pál, a váradi káptalan requisitora (1569-1572) 26

Várfalvi János, n 121

Varga Árpád (1951-1994), történész 8

- János (1927-2008), történész, levéltáros 115,144

- János, a kolozsvári iskola szász collaboratora (1631) 116

Varsolci István, a kisebb kancellária íródeákja (1613-1615), Kolozs vm jegyzője (1624-től), jogügyigazgató (1640-1647), fiscalis ügyész (1629-1639) 82

Vass Miklós, történész 21, 108

Vekov Károly (sz 1947), történész 9, 22, 164

Vér Ferenc (Jenői), fejedelmi udvari familiáris (1648) 158

Verdena, Johannes ferences szerzetes, prédikátor 87

Veres János, n 39

Verner Mihályné, polgár, Kolozsvár 97, 160

Verőczei János, a gyulafehérvári káptalan requisitora (1567-1573) 23

- Miklós, a gyulafehérvári káptalan kanonokja, hunyadi föesp (1544-1545), dékánkanonok (1546) 23

Vicei, polgár cs: Gáspár 106; István, kolozsmonostori requisitor (1674-1694) 61, 64, 96; Máté (mh 1623), 1601-től centumvir 96; Péter 145

Vingárt (Vingard), Fehér m, h 114

Virginás István, kisebb kancelláriai íródeák (1627), táblai ülnök (1667-1669), partiumi fiscalis director (1639-1653), kolozsmonostori requisitor (1666) 60-62, 96

Visk (Wysskowa), Máramaros/Ukrajna, h 143

Visó (Vişeu), Máramaros m, h 59
Vitéz, n cs: András 39; György 114; Tamás 39

Vizaknai György (1668?-1720), neves orvos, külföldi tanulmányok után Kolozsváron telepedett meg, ahol 1711-től requisitori tisztséget is viselt 63

- Péter, fejedelmi praefectus (1661-1664), vicearendátor (1664) 56

Vogha Simon, Kolozsvár városának felsőfüldi jobbágya 119

W. Kovács András (sz 1975), történész 39, 132

Wass György (mh 1594), Cegei, az újvári vár kapitánya (1590-1592, 1594), tanácsúr (1593-1594) és Kolozs vm isp (1573, 1576, 1579-1580, 1585-1587, 1592-1593) 74

Werbőczy István (1458-1541), erdélyi ítélőmester (1503-1516), országbírói ítélőmester (1503-1514), királyi személynök (1516-1525), országos kincstartó (1521-1522), nádor (1525-1526), I. János kancellárja (1526-1540), II. Lajos és I. János diplomatája, a Hármaskönyv összeállítója 49, 134

Werner Georg, magyar kamarai tanácsos, kir biztos Erdélyben (1552-1553) 21

Wesselényi Ferenc, főkamarás és tanácsúr Báthory István lengyelországi udvarában, tanácsúr Erdélyben (1592) 140; István 106-107

Wittenberg, város Németországban 76

Wolf Rudolf (1951-2008), történész 83

Zalánkeményi, n polgár, cs: Albert, vajdai jegyző (1534), majd erdélyi ítélőmester (1545 előtt) 72-73; Bálint, Erzsébet, János váradi káp- 
talani requisitor (1590), Miklós 73;

másik Miklós, kolozsvári jegyző

(1569-1576), kolozsmonostori

requisitor (1575-1576) 32, 47, 64,

72-73

Zalánkeményi cs 76

Zalavár, Zala m, h és vár 66

Zámbó Mihály, a nagyobb kancellária íródeákja (1607-1619), Bethlen

István titkára (1624) 144

Zaránd vm 40

Zeller Angléta, Kamuthi Balázsné 127

Zilahi János, a váradi káptalan

főrequisitora (1580-1581), a váradi vár jegyzője (1580) 52

Zólyomi Dávid, az ország generálisa (1630-1633), udvari főkapitány (1627-1633), Háromszék és Kővár főkapitánya (1630) 83, 88

Zsibó (Jibou), K-Szoln/Szilágy m, h 106

Zsigmond, magyar király (1387-1437) $43,49,56$

Zsombor (Zimbor), Kolozs/Szilágy $\mathrm{m}, \mathrm{h} 31,125$ 


\section{REZUMAT}

\section{CONVENTUL DIN CLUJ-MĂNĂŞTUR ÎN PERIOADA PRINCIPATULUI}

Pe teritoriul în formare al Principatului Transilvaniei erau trei instituţii ecleziastice care îndeplineau funcția de loc de adeverire şi emiteau documente autentice: capitlul Transilvaniei cu sediul la Alba Iulia, conventul din Cluj-Mănăştur şi capitlul din Oradea. Activitatea din perioada medievală a acestor instituții a fost deja parțial discutată în diferite studii şi articole, dar cercetarea nu s-a axat până acum pe perioada Principatului. Numai în cazul capitlului din Oradea această lipsă de documentare s-ar putea explica prin inexistența surselor arhivistice, dat fiind faptul că, după cucerirea cetății de către turci, arhiva capitlului s-a distrus cu desăvârşire; însă chiar şi aşa s-ar putea încerca reconstituirea activității locului de adeverire pe baza documentelor emise, păstrate în arhivele diferitelor familii şi instituții (aşa cum s-a făcut mai demult în cazul conventului din Szekszárd). Arhivele celorlalte două locuri de adeverire se păstrează şi astăzi în marea lor majoritate la Arhivele Naționale Maghiare din Budapesta (MOL), fiind posibilă astfel o investigație ştiințifică. Cercetarea trebuie să se axeze pe perioada premodernă iar publicarea protocoalelor locurilor de adeverire rămâne o sarcină de maximă importanță şi urgență, deoarece astfel s-ar crea o bază de date care ar extinde cunoştințele privind istoria Transilvaniei şi ar facilita investigațiile viitoare.

Această carte prezintă caracteristicele activității de emitere a documentelor autentice efectuate de către locurile de adeverire din Principatul Transilvaniei prin exemplul conventului din Cluj-Mănăştur, locul de adeverire ale cărui protocoale s-au păstrat în marea lor majoritate. Problema principală la care am încercat să răspundem este dacă locul de adeverire secularizat, mutat şi reorganizat împreună cu arhiva sa în interiorul zidurilor oraşului Cluj, a reuşit să satisfacă nevoile societății transilvănene privind emiterea şi păstrarea documentelor. De asemenea cercetarea a urmărit şi prezentarea detaliată a organizării şi a modului de funcționare a conventului precum şi a rolului jucat de acesta în perioada Principatului.

După formarea Principatului Transilvaniei, locurile de adeverire aflate sub jurisdicția principilor au fost reorganizate sub o formă diferită de cea din epoca medievală. Pe aceeaşi bază ca şi instituțiile similare din Ungaria a luat naştere în perioada discutată o instituție specifică Transilvaniei, cea a requisitorilor (căutători de scrisori), nobili laici, delegați de către principe să satisfacă necesitățile de emitere a documentelor legale şi de păstrare a arhivelor. După o perioadă de incertitudini, care a ținut până în 1575, timp în care activitatea locului de adeverire 
s-a rezumat la emiterea copiilor sub sigiliul oraşului, conventul a căpătat o formă de organizare complet nouă. Requisitorii delegați aveau de acum încolo dreptul să desfăşoare toate activitățile efectuate mai demult de locurile de adeverire din instituțiile bisericeşti; dar dat fiind numărul lor redus, alți dregători şi instituții (homo regius - delegații principelui, comitatele) au început să le ia locul în activitățile procedurale şi executorii. Astfel, chiar şi după reglementarea atribuţiilor requisitorilor (1575), executarea poruncilor principilor putea fi asigurată pe alte căi; iar în acest proces de restrângere a atribuțiilor locurilor de adeverire publicarea articolelor de lege Approbatae constituie un punct de cotitură. După a doua jumătate a anilor 1650, aşa-numita activitate externă a locurilor de adeverire (hotărniciri, puneri în stăpânire, ascultări de martori, etc.) pare să înceteze.

În acelaşi timp dezastrele care au marcat anul 1658, continuate de o instabilitate politică prelungită au produs o asemenea întrerupere în activitatea locului de adeverire, încât am putea considera că istoria premodernă a instituției se sfârşeşte în aceşti ani. Activitatea de emitere a documentelor era din ce în ce mai rară, conventul emitea la cerere mai ales copii ale unor documente din arhiva proprie şi nu acte ale mărturiilor depuse. Putem spune că în această perioadă se sfârşeşte istoria locului de adeverire şi începe cea a arhivei conventului.

Dacă am dori să tragem o concluzie finală privind activitatea conventului din Cluj-Mănăştur în perioada Principatului, trebuie să comparăm imaginea prezentată de către monograful locurilor de adeverire premoderne, László Papp şi requisitorul conventului István Pálfi (1655) legate de „produsele” locului de adeverire: protocoalele şi documentele emise. Atât cantitatea, cât şi calitatea materialului arhivistic demonstrează că, în forma sa reorganizată, conventul a rămas în continuare, pentru o perioadă însemnată de timp, unul dintre principalele instituții emitente de documente autentice din Transilvania. 


\section{THE CONVENT FROM KOLOZSMONOSTOR} DURING THE PRINCIPALITY

On the territory of the developing Transylvanian principality there were three ecclesiastical institutions which took part in the issuance of authentic charters: the Chapter of Transylvania residing in Gyulafehérvár, the Convent of Kolozsmonostor and the Chapter of Várad. Their medieval history has been already partially studied, but in neither of these cases the research did not cover their activity during the Transylvanian principality. Only in the case of Várad we could refer to the lack of sources because, after the capture of the fortress, the Chapter's archives perished, but even so someone could attempt, on the basis of the issued charters to reconstruct its activity (we already have such an example for the Convent of Szekszárd). Although truncated, the archives of the other two loca credibilia are preserved in the collections of the National Archives of Hungary, so any other scientific investigations are possible. The research of their early modern activity and the publication of a major part of the protocols remains an urgent and possible task of the historians. The publication of these sources would largely extend our knowledge of Transylvanian law and history of institutions, and they would generate a basic collection of sources for further research.

The main aim of this book is to present the characteristics of the charterissuing activity accomplished by the earlymodern Transylvanian loca credibilia by examining the case of the authentication place of the Convent of Kolozsmonostor, where the majority of the protocols have been preserved. We attempt to answer the following questions: whether the reorganized and secularized Convent, which has preserved its designation and has been moved together with the archives to Kolozsvár, has met the expectations of the society in terms of preservation of the documents and issuing of charters? How did it work and what was its role in the Transylvanian society?

After the establishment of the Transylvanian state, the loca credibilia that entered under its jurisdiction, underwent a peculiar transformation. On the same grounds as similar institutions from Hungary, a specific Transylvanian institution, the office of the requisitors came to life to satisfy the needs of the society for authentic charters and to ensure the conservation of the archives. After twenty years of uncertainty, during which the secularized institution issued copies from the Convent's archives under the seal of the city, the time for reorganization has arrived. The appointed requisitors had the right to complete all the activities made earlier by the places of 
authentication, but because there number was small, other institutions (envoys of the voivodes, counties) have gradually taken their place in the external authentication activity. In this process, the articles of Approbatae presumably constituted a turning point. From the second half of the 1650s, the external authentication activity (inspection of boundaries, seisin of estates to new owners, inquiry, etc.) was likely to disappear.

At the same time, the disasters that occurred in 1658, and the subsequent longterm instability, caused such a break in the activity of the Convent that we could consider it as the end of the institution's earlymodern history. Thereafter the charter-issuing activity was more and more casual, the place of authentication became mere depository of charters and produced copies of the documents in his custody. One could say that it was the moment which marked the end of the institution's history of and the beginning of the archive's history. In the age of principality the archives of the Convent together with the sacristia of the Chapter from Gyulafehérvár and probabily Várad as a result of the measures taken by the princes and the Orders have played the role of the state's "National Archives".

Finally, in order to reflect on the activity of the Convent from Kolozsmonostor during the age of principality, we should compare László Papp's point of view, based on the previous literature and law-articles, and the impedimentums listed in 1655 by one of the requisitors, István Pálfi with the "products" of the Convent's activity: the registers (protocolla) and the charters. Both the quantity and the quality of the preserved archive materials prove that the reorganized Convent remained for a long time one of the major charter-issuing institutions of Transylvania. 


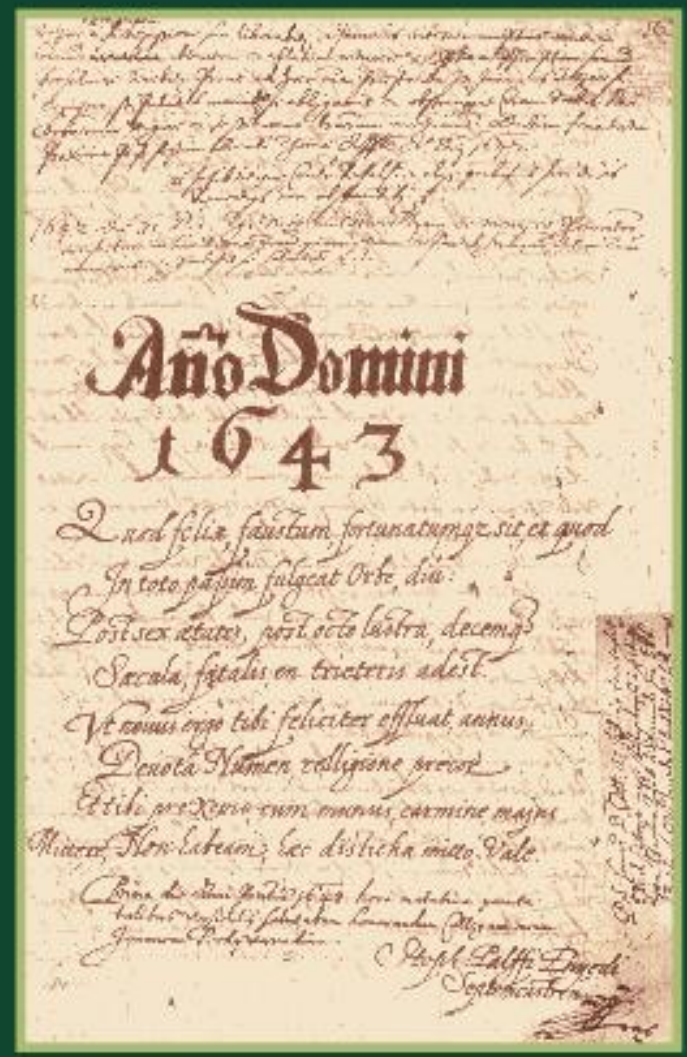

Az erdélyi állam kialakulásával a fennhatósága alá került hiteleshelyek is sajátos útra léptek. A hasonló magyarországi intézményekkel azonos alapokra épülve egy különleges erdélyi intézmény, a requisitori hivatal jött létre abból a célból, hogy a társadalomnak a jogbiztosító iratok kibocsátása és megốrzése iránti igényét továbbra is kielégithesse. Kötetünk célja a kora újkori közhitelủ tevékenység erdélyi sajátosságainak vizsgálata egy olyan intézmény, a kolozsmonostori konvent hiteleshelyének esetében, melynek fejedelemség kori jegyzốkönyvei nagy részben fennmaradtak. Lényegében arra próbálunk választ adni, hogy a szekularizáció után világi alapon újjászervezett konvent, amely elnevezését megổrizve Kolozsvárra költözött, hogyan mủködött, milyen szerepet töltött be az erdélyi társadalomban, hogyan felelt meg az iratkibocsátás és -megốrzés terén jelentkezổ elvárásoknak.

ISBN 978-606-8178-46-2

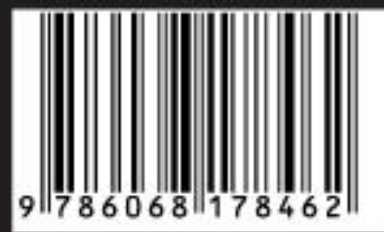

